$$
\begin{aligned}
& S \\
& 451 \\
& V 5 A_{4} \\
& 1913
\end{aligned}
$$

\title{
LIBRARY OF CONGRESS
}

|||||||||||||||||||||||||||||||||||||||||||||||||||||

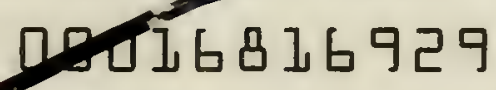


\% 



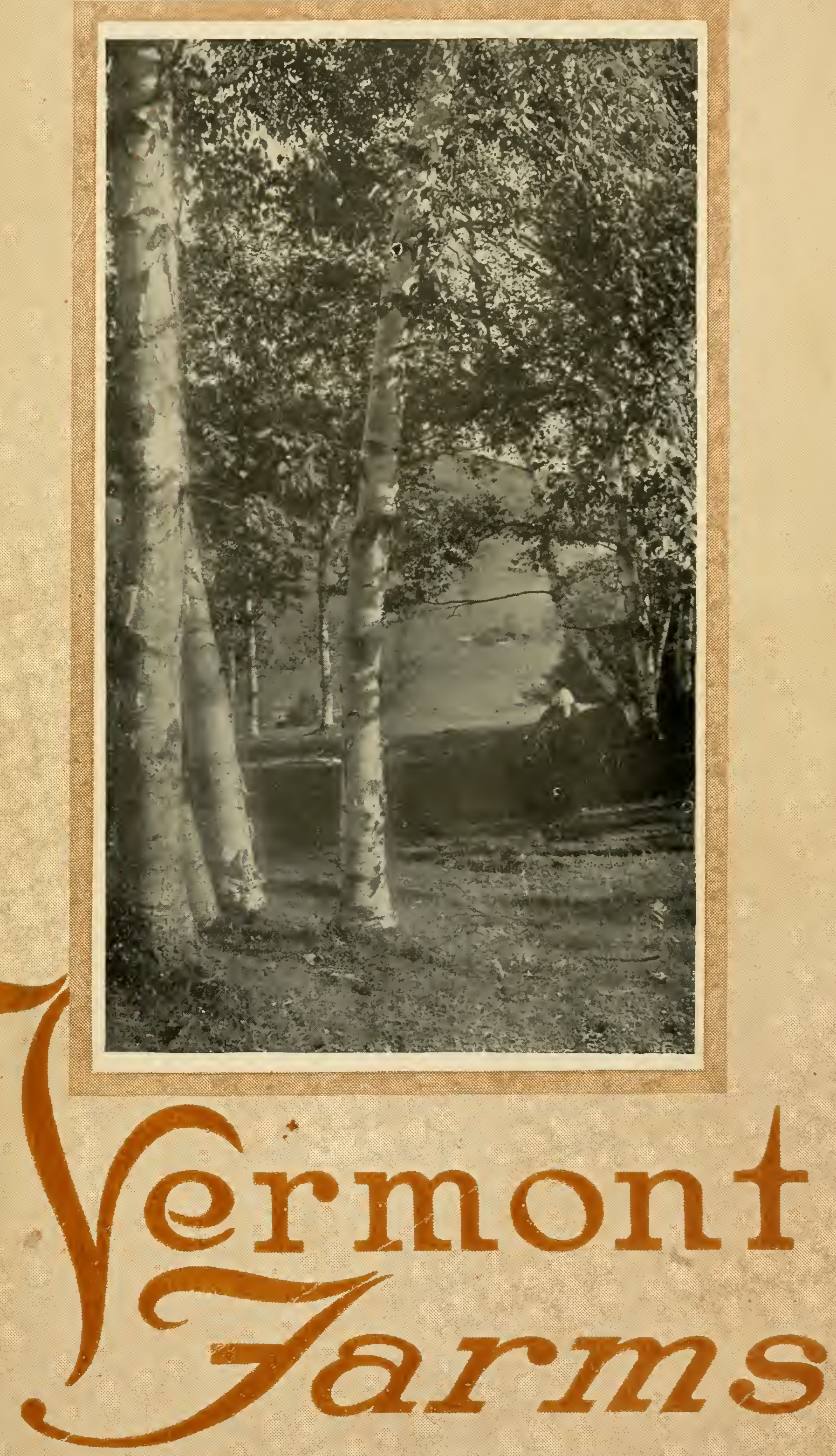



\section{VERMONT FARMS}

Some Facts and Figures Concerning the Agricultural Resources and Opportunities of the Green Mountain State

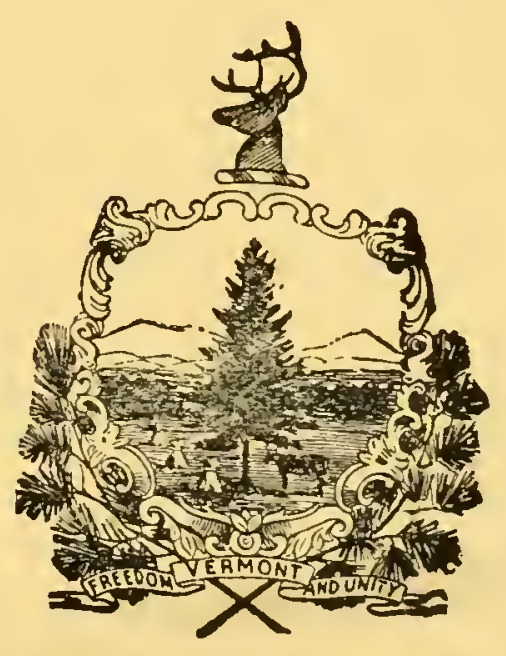

Issued by THE VERMONT,(BUREAU OF)PUBLICITY OFFICE OF SECRETARY OF STATE ESSEX JUNCTION, VERMONT 


$$
\begin{array}{r}
S 451 \\
V 5 A 4 \\
1913
\end{array}
$$

THE CALEDONIAN COMPANY

ST. JOHNSBUKY, VRRMONT D. of D

JAN 81914 


\section{SOME VERMONT AGRICULTURAL FACTS}

What inducements can Vermont offer an ambitious, wide-awake farmer to settle in the Green mountain state? That is a fair question and demands an equally fair answer. Any satisfactory answer must include information regarding agricultural resources, opportunities and profits. An impression has been created, and has been accepted in very many quarters as a fact, to the effect that upon the broad prairies of the West was the place of all others where money might be made in farming, but impressions often are misleading and sometimes are incorrect. This little book will undertake to show, not by empty boasts and rhetorical statements, but by well authenticated facts and figures, that the state of Vermont offers opportunities for profitable farming equal to all and superior to most of the states of the Union.

But somebody will say that Vermont is a little state, consisting mostly of mountains, that her soil is rocky and sterile, and that it is ridiculous to claim that this little commonwealth can be compared with the great states of the Niddle West as a profitable farming region. It is true that Vermont is a mountainous state, and her people are proud of the fact. Her mountains are a source of strength and beauty, but they are useful as well as beautiful. They condense the moisture that the clouds bear inland from the Atlantic ocean and make possible the abundant verdure which has given to these lofty hills their familiar and appropriate name, the Green Mountains. They furnish excellent timber, and the hill country affords that wonderful pasture land which has put Vermont in the lead of all other commonwealths as a dairy state, taking area and population into account. Nothing could be farther from the truth, however, than the idea that Vermont contains only small and undesirable farms, or that the soil of Vermont is sterile and that this is an unprofitable agricultural state.

Theodore N. Vail today is one of America's great captains of industry. Probably no great industrial leader of modern times has shown a keener comprehension of the statesmanship of business than Mr. Vail. His opinion concerning industrial affairs is that of an expert. Listen to what he says of Vermont in the following statement printed in a magazine:

"Agriculture including all its branches is its (Vermont's) greatest asset and in this is the greatest industrial possibility. The backbone of Vermont's future will be its agricultural resources, and will be the source from which the wealth and comfort of its people will be largely drawn. The cheap competition of the West is past. Production of grain, meats, all that land produces, will never again be met with that competition from the great farms of the West where crops 
were raised almost without labor and where all were producers. Eastern prices for all that Vermont can raise and produce will always be remunerative for those who produce intelligently. Thrift and industry directed by intelligence will always be prosperous in Vermont. With a little painstaking instruction Vermont boys can be taught how to make the hillside and valley homes more desirable than any they can find by wandering.

"Vermont dairy products are the standard. Vermont beef could not be surpassed in the days when every farm had, and will have again, those big steers and oxen. Vermont mutton is not excelled in the world. Vermont fruit, particularly its apples, are inferior to none when given proper attention. Vermont horses are the best foundation stock from which to breed such herses as are now necessary to meet the market requirements."

Maxwell Evarts, one of the prominent lawyers of this country, a son of William M. Evarts, one of America's well-known statesmen, has said of Vermont that "alone of all New England she has withstood the agricultural competition of the West. This competition is now ended and Vermont is coming forward with great strides to her old place of a leader among the farming states."

Both Mr. Vail and Mr. Evarts have shown their faith in Vermont by establishing their homes and cultivating farms in the Green mountain state.

Prof. E. H. Farrington, head of the department of dairy husbandry in the University of Wisconsin, recently visited Vermont, and declared as a result of his visit that Vermont is a much misunderstood state. He had no idea there was so much fertile land here and he said that the people of the West had the same mistaken opinion of the size of our farms. He expressed the belief that Vermont was one of the best parts of the country in which a man might engage in farming, mentioning the cheapness of the land and the nearness to markets as important inducements. He found our farms prosperous and the average farm homes even better than those in the West.

Professor Farrington's idea that there are no big farms in Vermont was dispelled by visits to various parts of the state. To those who have not seen our broad and fertile farms, and who hold the same erroneous opinion, it may be well to call attention to the last census report, which shows the size of the average farm in the United States to be 138.1 acres, and the size of the average Vermont farm to he 142.6 acres. The size of the average farm in the states of the Central West is as follows: Ohio, 88.6 acres; Indiana, 98.8 acres; Illinois, 129.1 acres; Michigan, 91.5 acres; Wisconsin, 118.9 acres; Minnesota, 177.3 acres; Iowa, 156.3 acres. Only two of these states surpass Vermont in the size of the average farm. 


\section{A Few Fertility Facts}

Those persons who have considered Vermont soil barren will do well to consider the following facts compiled from the United States census and crop reports :

Last year only eight states raised more bushels of corn per acre than Vermont. For the past four years the average number of states raising more corn per acre than Vermont was six. Vermont's average yield for the four-year period mentioned was nearly twice the average yield for the whole country. The average price in Vermont paid farmer's December 1 st for the past four years was $\mathbf{4 3 . 6}$ per cent greater than the average price paid throughout the United States. During only one year of the four mentioned did one of the big corn states surpass Vemont's yield of bushels per acre. For the forty-year period, from 1870 to 1909 , inclusive, Vermont ranks first in average yield of bushels of corn per acre.

Last year only five states, and those in the irrigated region of the West, raised more bushels of spring wheat per acre than Vermont. The average Vermont yield during the last four years was nearly twice that of the United States. The average price paid in Vermont during the last four year's was more than twenty cents per bushel greater than that reported for the entire United States. During the period from 1870 to 1909 , inclusive, only two states, and those in the irrigated regions of the West, surpassed Vermont in the average yield of bushels of wheat per acre.

Last year only eight states raised more bushels of oats per acre than Vermont and this state led all the big oat producing states in average rield and price. Vermont's average price for the past four years was nearly fourteen cents per bushel grearer than that of the United States. For the forty year period, 1870 to 1909 , Vermont led the Union in the average yield of bushels of oats per acre.

Last year only seven states raised more bushels of barley per acre than Vermont. During the past four years Vermont surpassed in a marked degree both in yield and price all the big barley growing states in the Union. The average Vermont price for that period was 14.4 cents per bushel greater than the average price of the United States. During the period from 1870 to 1909 only four states exceeded Vermont's average yield per acre.

Last year only three states raised more bushels of rye per acre than Vermont, and Vermont led all the great rye producing states in yield per acre and price. The average Vermont price was 19.3 cents per bushel more than the average United States price. During the forty years from 1870 to $\mathbf{1 9 0 9 ,}$ only five states raised more bushels per acre of rye than Vermont.

Last year only one state led Vermont in yield of bushels of buckwheat per acre. During the past four years Vermont led the great buckwheat growing states in average yield and price. During the forty-year period from 1870 to 1909 only one state showed a better averige yield than Vermont.

Last year only seven states raised more bushels of potatoes per acre than Vermont. For the past four year's Vermont's arerage yielu has exceeded that of all the great pototo growing states with the single exception of Maine. Vermont's average for this period exceeds the average yield for the United States by 33.7 bushels per acre. For the period 1870 to 1909 , only tro states show a larger average yield than Vermont.

Last year Vermont was one of four states tied for first place in yield of pounds of tobacco per acre. During the past four year's Vermont's average yield and price was almost twice the United States average reported.

For the forty year period, 1870 to 1909 , Vermont led the Union in: average returns per acre for the three most important cereals, corn, wheat and oats. 
Considering area and population, Vermont is by far the most notable dairy state in the Union, being really in a class by itself. Vermont produces more pounds of butter per capita than any other state. Only three states produces half as much, only six states a third as much and only eight states a fourth as much. Vermont leads all other states in pounds of butter per farm. Only four states produce half as much, only seven states a third as much, only fifteen states a fourth as much. Vermont leads the Union in production of pounds of butter per cow. Vermont leads the Union in ratio of dairy cows to population. In pounds of butter per square mile, Vermont is far in lead of any other state. In dairy cows per square mile, only one state leads Vermont, and in all cattle per square mile, only two states lead Vermont.

In value of all crops per capita of rural population, according to the last census figures compiled, only ten states surpassed Vermont. In value per acre of all cereals produced in 1909 , only seven states supassed $V$ e:Pmont.

These matters will be taken up later in greater detail, but the tacts mentioned are sufficient to show that instead of being a sterile region, Vermont is one of the most fertile regions to be found in the entire United States. Proximity to the great cities of the nation, the best markets in the world, is an asset of great value to Vermont. The state is not dependent upon a single railroad, but it is served by some of the most important railroad systems of the country, and the Champlain valley has the added benefit of water transportation to the seaboard.

Professor Farrington was correct in asserting that the cheapness of land was one of the attractions which Vermont agriculture offered to a person seeking a good farm investment. There are several reasons why Vermont farms are quoted so much lower per acre in the census returns than the lands of the prairie states. Many Vermont farms contain a considerable forest area, and pasture land too rough for tillage. The forests not only furnish timber but often contain good maple sugar orchards. The sweet, verdant pastures make possible the high rank which Vermont holds as a dairy state, but these lands are not appraised as high as fields that may be tilled.

From the beginning Vermonters have been pioneers. Every statewest of Lake Champlain has received a goodly number of citizens from the Green mountain state, who have been attracted by the opening of a new region. The lure of the city has been a strong attraction for many, with tales of great fortunes to be won. Now the tide has turned. Prices of agricultural products are materially higher than they were twenty or thirty years ago. Farmers are learning to till the soil more intensively and more scientifically. Prices of Vermont farms are rising and will continue to rise in all probability, for they are altogether too low, judged by what these farms produce and by the still greater amount that they may be made to produce. Persons desiring to take advantage of the low prices of Vermont farms should not delay in securing an option as prices must continue to advance according to all generally accepted financial rules. 


\section{BaCK to the East}

More and more the attention of seekers for agricultural opportunities is being turned back to the East as a region offering on the whole more than any other section of the country to the farmer who has ambition and energy, but not the capital sufficient to pay fancy prices for land. Not only are the prices for farm lands in the Central West so high that it is difficult for the young man to purchase a homestead in that section, but it is also reported that these fertile prairies are showing signs of exhausted fertility.

In respect to all the fundamental requirements of soil, markets and prices, Vermont has so much to offer that no farmer seeking the most and the best for his money can afford to ignore them. Vermont is one of the best states in the Union in which to establish a home. The home surroundings and advantages consititute a most important factor and one that cannot easily be estimated in dollars and cents. Vermont has good schools, good churches, good roads, a healthful climate, a large mileage of telephone lines, extensive rural free delivery of mails, a large number of Grange organizations, delightful scenery, and all those things that make every day life pleasant and desirable.

\section{Facts From The Census}

A few preliminary facts may be considered profitably before a more detailed description of Vermont's agricultural advantages is given. Vermont's area is 9,564 square miles. The population of the state, as reported by the census of 1910 , was 355,956 . The percentage of the land area of Vermont in farms is 79.9.

The rural population of Vermont is 52 per cent of the total population.

The number of farms in Vermont in 1910 was 32,709.

The average value of farm property in Vermont in 1910 was $\$ 4,445$.

The average number of acres in a Vermont farm in 1910 was 142.6 .

The value of all farm property in Vermont in 1910 was $\$ 145$,399,728 .

The value of all crops in Vermont in 1909 was $\$ 27,446,836$.

The total value of farm property in Vermont increased during the last census decade 34.1 per cent.

The value of all crops in Vermont increased during the past decade 51 per cent.

The average value of Vermont farm land per acre increased during the past decade 29.1 per cent.

The value of Vermont livestock on farms in 1910 was $\$ 22,642,766$, representing an increase of 26.9 per cent during the decade.

In 1910 Vermont had 430,314 cattle on farms, or nearly one-third of all the cattle in New England. 
In 1910 Vermont had 265,483 dairy cows, being surpassed by twenty-five states in number of cows and by fourteen states in value of all dairy products.

In 1910 Vermont had 80,781 horses, valued at $\$ 8,591,357$.

In 1910 Vermont had 94,821 swine, valued at $\$ 974,779$.

In 1910 Vermont had 118,551 sheep, valued at $\$ 538,991$.

In 1910 Vermont had 938,524 fowls, valued at $\$ 607,787$.

In 1910 Vermont had 10,215 colonies of bees, valued at $\$ 44,349$.

The following statement regarding Vermont soils and the newly employed agricultural advisers has been prepared for this book by Prof. J. L. Hills, Dean of the State Agricultural College of Vermont.

\section{Concerning Vermont Solls}

"The phrases 'Vermont agriculture' and 'abandoned farms', spell the same thing to many people. Newspapers outside the state are apt to refer to Vermont's farming operations in dismal terms. Such treatment is unjust, for the present outlook is encouraging and the future prospects bright. Few farms are abandoned save in those localities where modern farming operations are, as the physician would say, counter-indicated. The reversion of some Vermont farms of two generations ago to forest conditions is a cause for congratulation, and not for condolence. They were never meant by the Almighty to be farms, and the men who wrested them originally from the forests were working against His plans. In the valleys and on the lower hill slopes agriculture may be, and is being, conducted successfully and profitably. On such areas, Vermont soil is not exhausted, though it may be temporarily weary.

"Vermont soil is inherently fertile. The detritus of the granitic rocks of the Green mountain range, ground in the mighty mills of the old-time glacier, sorted by the rushing waters which followed its melting, commingled with the debris of thousands of years of unharvested vegetation, worked over by heat and by cold, by wind and by wave, by water and by ice, by frost and by snow, by flood and by rain and by the multitudinous effects of the weather throughout the ages past. It has made of this fair state a more fertile land than some of her less favored sisters. Not for naught are our mountains verdure clad. Not idly, not without a reason, is Vermont called the Green mountain state in contradistinction to her Eastern neighbor, the Granite state. Alone among the states, save Florida, her very name bespeaks ferility. Ver-mont means "green mountain," and her mountains are 'verdure clad hillsides,' because the soil upon them is naturally fertile.

"Not only did Nature endow her richly in this respect, but her bounty has not been as prodigally wasted as in some other sections. This statement is made advisedly, and has this firm basis in reason; that for generations Vermont has been a dairy state, a butter-making section. In no other state in the Union are there so many cows crowded 
upon so small arable area. She far outclasses all her sisters in this respect. As a natural correlary of this condition several things follow, namely :

(1) Her crops are fed at home, and not removed from the farm or the locality, and this to a larger extent than obtains anywhere else in our broad land.

(2) Large grain purchases are naturally made in order to maintain the evenness of the milk flow.

(3) Butter sales remove but a minute amount of fertility from the farm, a ton carrying barely fifty cents' worth.

"All this means that Vermont farmers have for generations kept their fertility upon their own farms, and sold but little of it. The cotton farmer and the grain farmer sell the very essence of their real estate. The man who sells butter, however, sells elements gathered from the air and not from the soil. It furthermore means that for two generations these thrifty Vermonters have translocated fertility in the shape of cottonseed meal from the South and wheat bran, middlings and mixed feed from the West, to place upon their Vermont fields in the form of manure. Naturally fertile, the methods of Vermont farming have tended to increase and not to decrease the plant food content of her soils, and large areas are, as a consequence, richer today even than they were at the cutset.

"Vermont's topography is irregular. Barely one-third of her entire land area is made up of pasture (of the better sort), of mowings and of plowed fields: nearly two-thirds of her area is occupied by wood-lots, forest areas and rough lands. Such as is good, is good; such as it not adapted to agricultural purposes is largely covered by forests, is being set out to forests, or is reverting to forests. 'The proportion of improved lands, however, notwithstanding topographical irregularities, is decidedly greater than is found in either Maine or New Hampshire; somewhat greater than is found in Massachusetts or Rhode Island; and is essentially the same as that occurring in Connecticut.

"No systematic soil survey has been made in Vermont, save one carried out some ten years ago by the Bureau of Soils of the United States Department of Agriculture, which mapped out an area of the lake towns in Addison county from Ferrisburg to Orwell stretching back about ten miles from Lake Champlain. This area includes perhaps the largest area of soils of relatively even character; and yet it covered in all but a little more than two per cent of the entire area of the state. It established nine distinct soil types, the most important being a clay and two sandy loams. Hay was found to be the most important crop grown on the heavier soil. It grew at the rate of approximately a ton to the acre, but the survey developed the fact that-when properly handled-it was easily capable of growing two or more tons to the acre. This soil makes an excellent pasture soil, but is ill adapted to the growth of corn. The stony loams were 
found to be well fitted to apple orcharding, and to some extent to be thus used. They do not lend themselves well to the growth of corn or hay and are largely occupied by pasture or wood lot, save where crcharding obtains. *

"The alluvial and bench lands of the river beds, the valley soils in general, are fertile; and these valleys ramify in all directions. Vermont is full of valleys. It has been said that while the Almighty can do anything, there is one thing which even He cannot do, and that is to make two ranges of mountains without a valley in between. Considerable upland soil in Vermont is of a strong character, and, if not acid produces well. If it is found to be acid, liming tends to remedy the situation.

\section{Agricultural Advisers}

In another important respect Vermont is far ahead of other New England states. At the present writing there are in five Vermont counties-Bennington, Windham, Windsor, Orange and Caledonialocal agricultural advisers; and in three other counties-Rutland, Franklin and Orleans-steps have been taken looking towards the employment of similar agents, who doubtless will be employed within a comparatively short time. This will make eight of the fourteen counties thus supplied. These local agricultural advisers are employed jointly by an organization of the farmers and business men of the county, by the Office of Farm Management of the United States Department of Agriculture, and by the College of Agriculture of the University of Vermont. Their functions are purely advisory, and purely local. They are at the service of the farmers in their respective counties, going on call and without charge to advise them as to their farming operations. Differing in this respect from the 'absent treatment' often applied by the officials of the State College of Agriculture, they are, in the slang phrase, agricultural 'Johnnies on the spot,'Johnnies who are farm born and farm raised, educated at an agricultural college, experienced in farming operations after leaving college, up-to-date, wide-awake, well informed. This system is in vogue in no other New England state at present, and few states in the Union are as well covered by this sort of public service as is Vermont. A Vermont farmer, actual or prospective, can get in touch with his local adviser, and without charge get the benefit of his judgment as to any matter which perplexes him concerning his agricultural operations. It goes without saying that the longer the local agent resides in a county and gains local experience, the better fitted is he to proffer a judgment which is thoroughly safe. Prospective settlers in Vermont may well take into account this important factor, which should tend to improve the likelihood of their success in gaining a foothold in their new location."

*See 6th Report, Bureau of Soils, U. S. D. A. (1904). 


\section{Expert Aid For Farmers}

Hon. E. S. Brigham, State Commissioner of Agriculture, prepared an article not long ago for the New England Homestead as a part of a symposium on "New England's County Demonstration Farms." This article was written evidently before the one prepared by Professor Hills for this book, and at the time when it was written less work had been accomplished than when Professor Hills' article was furnished, but it contains matters of much importance bearing on the same general subject, and is given herewith:

"I think Vermont is ahead of her sister New England states in this expert movement. Three of our counties, Windsor, Benningt: $\eta$ and Orange, are organized and have raised a sufficient sum of money in the county to enable them to secure the Burt Ball fund of $\$ 1000$ from Chicago, and to secure the assistance of the department of agriculture to the extent of $\$ 100$ per month. Windsor county secured the services of J. Coryell, headquarters White River Junction, Vt. Bennington county is served by Mr. Sherman, headquarters at Manchester. Orange county, to my knowledge, has not yet employed a man. On the strength of the expectation that an additional appropriation would pass the last Cougress, a number of additional counties in Vermont organized county farm bureaus and raised a sum of money. Franklin county had subscribed February 20 the sum of $\$ 1500$. Lamoille county had organized with C. F. Smith as president of the bureau, but I do not know the state of affairs there at present. Rutland county has organized and seems to have raised a large sum of money. Orleans county is planning to effect an organization. Windham county has organized and has a sum of $\$ 2000$ raised. The failure of Congress to pass a larger appropriation has caused a temporary halt in the proceedings. Most of our counties are not able to finance the proposition with simply the assistance of the Burt Ball fund. Rutland county, however, intends to forge ahead and raise a sum of $\$ 6000$ in the county to finance the movement at once. Caledonia county is also organized.

"I believe that the organization in all our counties will be kept intact, and that as soon as Congress increases the appropriation so that the department of agriculture can help to the extent of $\$ 100$ per month, all the counties I have enumerated will be ready to begin work. Our other counties have manifested interest to some extent, and I believe it will be but a question of a short time when all our Vermont counties will have these experts at work. I believe it is a good thing for the state, and it is gratifying that our people have taken such an interest in this matter.

"Our last legislature passed an act enabling towns in the county to vote a sum of money at the annual town meeting for the support of a county expert. One of the counties, Orange, raised a good part of the money at this last town meeting. In so far as I know the other 
towns have raised the money by private subscriptions. For instance, in our home county, a man appointed to solicit funds in the town of Berkshire spent four days driving among his neighbors and raised $\$ 180$ in $\$ 2$ subscriptions. I believe this is the most favorable kind of solicitation, because if a campaign is waged in this way the farmers generally have it brought to their attention, and if they are impressed with the proposition to the extent that they will participate in the way of giving funds, they will feel a greater personal interest in the expert and will utilize his services more than if the whole thing came as a free gift from wealthy men."

The Commissioner of Agriculture has interested himself particularly in such important matters as markets and the obtaining of a supply of farm labor.

\section{DAIRYING}

Dairying constitutes one of the principal features of Vermont agriculture. Briefly stated, the census figures show that in 1909 Vermont produced on farms and in factories $35,393,187$ pounds of butter and $3,008,540$ pounds of cheese. In addition to this amount $13,342,666$ pounds of condensed milk were manufactured. The value of all Vermont's dairy products in 1909 is given by the census as $\$ 12,128,465$.

There were $15,165,692$ pounds of butter made on farms and $27,256,877$ pounds of butter made in factories. There were 245,884 pounds of cheese made on farms and $2,762,656$ pounds of cheese made in factories. In the manufacture of butter, cheese and condensed milk in factories in 1909, Vermont ranked ninth in number and tenth in value of products. In 1909 Vermont ranked seventeenth in aggregate amount of butter made on farms and in factories and ninth in the aggregate amount of cheese made on farms and in factories.

Although Vermont is only a little state, having an area of less than ten thousand square miles, it outranks in the aggregate amount of dairy products many states much larger. When its comparative size is taken into account, it easily leads the Union as tables compileri from census reports and embodied in this article will show.

The headquarters of two of the great dairy organizations of the county, the Holstein-Friesian Association and the Ayrshire Breeders' Association, are located in Vermont, the former at Brattleboro and the latter at.Brandon, and the president of the American Jersey Cattle Club is a Vermonter, Elmer A. Darling of Burke.

Vermont stands at the head of the list in number of cow testing associations, this state and New York being tied for first place in number of associations when the last report was made. When the unprofitable cows are liminated from our herds it will be possible for Vermont to make a showing much better even than the excellent record just quoted. There are splendid opportunities for dairying in this state. Vermont butter already has won a high reputation in the great produce markets and to engage in dairying in Vermont is to 
follow one of the lines of least resistance. The Vermont Dairymen's Association is said to be the largest of its kind in the country and one of the very oldest.

\section{Milk Shipments}

It is not possible to obtain exact information regarding the shipments of milk out of this state, but it is carried on at the present time upon a large scale. This business has grown up largely within a few years. It is impossible at the present time to say how much milk was shipped out of the state when the census figures for dairying were compiled in 1910, or how much, if any, reduction in Vermont's production of butter and cheese has resulted from such shipments.

The bulk of the freight business of Vermont is done by three lines of railroad, although several other roads do considerable Vermont business in the aggregate. One of the most important railroads in Vermont reports that in 1912 it shipped out of the state 1261 cars of milk, each car containing 300 ten-gallon cans, 1377 ten-gallon cans in smaller lots and 18,584 ten-gallon cans of cream. This amounts to $3,796,770$ gallons of milk and 185,840 gallons of eream or $15,187,080$ quarts of milk and 743,360 quarts of cream. Another imporicis: Vermont railroad reports that it shipped out of the state during the year 1912, 1833 cars of milk, each car containing 300 ten-gallon cans, and cream shipments, amounting to 31.63 cars, each containing 300 tengallon cans. This represents 5,499,000 gallons of milk, or 21,996,000 quarts, and 94,890 gallons, or 1,122,920 quarts of cream. These two reports, therefore, represent 37,183,080 quarts of milk, and 1,866,280 quarts of cream. Assuming that the third railroad, which did not report, carried an equal amount-and the other railroads which do a smaller amount of business are likely to bring the total above rather than below the figures quoted--it may be safe to credit the third railroad with shipping 18,600,000 quarts of milk and 930,000 quarts of cream. This would represent practically 56,000,000 quarts of milk and 2,800,000 quarts of cream shipped out of Vermont in 1912. While it is not claimed that these figures give more than an approximate idea of the extent of the shipments of milk and cream, it will be seen that these shipments are very large when the other branches of Vermont's dairy industry are taken into consideration.

\section{Raising Beef Cattle}

There are also good opportunities in Vermont to produce beef cattle. President E. T. Fairchild of New Hampshire State College, in his inaugural address, recently called attention to the fact that there were six millions fewer cattle in this country now than there were ten years ago, while there are ten millions more people to be added to the consumers of beef.

The manager of one of the largest farms in this state, believing in the use of stable manures for maintaining soil fertility, and desiring 
to have stock enough to consume the hay and roughage grown on the farm, in August, 1911, bought a carload of yearling beef steers in Chicago. On arrival they were turned out to pasture where they remained until fall. During the winter season they were yarded and fed all the hay and roughage they would eat, but no grain. In the spring of 1912 they were again turned out to pasture where they remained until fall. Then they were taken up and fed for the purpose of fattening, being sold during January and February of this year at a good profit. They were fat, handsome, two-year-old beef and brought top prices. The experiment was so satisfactory that another lot of seventy-five head has been bought and the process will be repeated, being considered more profitable than the selling of hay and forage. That the raising of cattle is likely to be profitable for an indefinite period, is indicated in an address recently delivered by J. A. Spoor, chairman of the board of directors of the Union Stockyards at Chicago. He summed up the whole situation as follows:

"1. There is a world shortage of cattle and cheap beef is the thing of the past.

"2. The farmers and stock raisers of the United States have nothing to fear in the way of cattle or beef competition, from either Mexico, Canada or South America during the next decade or longer.

"3. Henceforth the corn belt farms must be looked to more than ever before for our domestic beef supply or else the American people must face a beef famine.

"4. To save the calves and to breed and raise more and better cattle on their farms, is not only a duty which the corn belt farmers owe to their country, but also a necessity for preservation of the declining fertility of their own lands."

With Vermont's superior pasture land and the ability to raise large crops of corn, an excellent opportunity is afforded, not only to increase the dairying industry, but also to raise beef cattle in considerable quantities for a market in which the demand exceeds the supply.

Briefly stated, Vermont's advantages as a dairy state are her shady and well watered hill pastures, her sweet and nutritious grasses in great abundance, her large acreage of forage crops, and her numerous silos.

While the principal breeds of dairy cows in Vermont are Holsteins, Jerseys, Ayrshires and Durhams, several other breeds are well represented. The Brown Swiss cow "Hirz," in the Speedwell Farms herd at Lyndon, Vt., owned by T. N. Vail, has a record of producing 14,067 pounds of milk and 723 pounds of butter in one year.

Following are some tables based on United States census figures, giving practical illustrations of Vermont's standing as a dairy state: 
Ratio of Dairy Cows to Population in 1909

Alabama

Arizona

Arkansas

California

Colorado

Connecticut

Delaware

Florida

Georgial

Idaho

Illinois

Indiana

Iowa

Kansas

Kentucky

Louisiana

Maine

Maryland

Massachusetts

Michigan

Ninnesota

Mississippi

Missouri

Montana
1 to 5.4 Nebraska

1 to 7.0 Nevada

1 to 3.6 New Hampshire

1 to 5.0 New Jersey

1 to 5.5 New Mexico

1 to 9.0 New York

1 to 5.6 North Carolina

1 to 6.4 North Dakota

1 to 6.4 Ohio

1 to 3.7 Oklahoma

1 to 5.3 Oregon

1 to 4.2 Pennsylvania

1 to 1.5 Rhode Island

1 to 2.2 South Carolina

1 to 5.5 South Dakota

1 to 5.9 Tennessee

1 to 4.7 Texas

1 to 7.1 Utah

1 to 19.5 Vermont

1 to 3.6 Virginia

1 to 1.9 Washington

1 to 4.1 West Virginia

1 to 3.8 Wisconsin

1 to 4.8 Wyoming
1 to 1.9

1 to 4.7

1 to 4.2

1 to 16.4

1 to 6.3

1 to 6.0

1 to 7.1

1 to 2.2

1 to 5.2

1 to 3.1

1 to 3.8

1 to 8.2

1 to 23.2

1 to 8.3

1 to 1.5

1 to 5.5

1 to 3.8

1 to 4.9

1 to 1.3

1 to 5.7

1 to 6.1

1 to 5.0

1 to 1.5

1 to 4.4

Pounds of Butter Per Capita in 1909

Alabama

Arizona

Arkansas

California

Colorado

Connecticut

Delaware

Florida

Georgia

Idaho

Illinois

Indiana

Iowa

Kansas

Kentucky

Louisiana

Maine

Maryland

Massachusetts

Michigan

Minnesota

Mississippi

Missouri

Montana
(No record) Nebraska

6.7 Nevada

19.8 New Hampshire

22.1 New Jersey

15.2 New Mexico

4.8 New York

10.8 North Carolina

2.2 North Dakota

10.4 Ohio

18.1 Oklahoma

12.6 Oregon

20.3 Pennsylvania

57.2 Rhode Island

28.5 South Carolina

16.8 South Dakota

(No record) Tennessee

20.7 Texas

7.6 Utah

i.5 Vermont

30.5 Virginia

59.5 Washington

15.9 West Virginia

15.9 Wisconsin

10.9 Wyoming
41.9

17.6

15.8

1.7

(No record)

7.6

11.8

34.8

17.0

18.8

21.0

11.9

(No recora)

8.1

39.6

18.2

17.2

16.6

96.6

13.0

15.8

(No record)

56.0

13.5 
Pounds of Butter Per Farm, 1909

$\begin{array}{lrlr}\text { Alabama } & \text { (No record) } & \text { Nebraska } & 385.2 \\ \text { Arizona } & 149.5 \text { Nevada } & 536.8 \\ \text { Arkansas } & 150.3 \text { New Hampslire } & 728.5 \\ \text { California } & 596.2 \text { New Jersey } & 131.1 \\ \text { Colorado } & 264.4 \text { New Mexico } & \text { (No record) } \\ \text { Connecticut } & 203.2 \text { New York } & 321.7 \\ \text { Delaware } & 202.1 \text { North Carolina } & 102.6 \\ \text { Florida } & 34.0 \text { North Dakota } & 270.2 \\ \text { Georgia } & 93.8 \text { Ohio } & 297.9 \\ \text { Idaho } & 191.4 \text { Oklahoma } & 163.8 \\ \text { Illinois } & 286.5 \text { Oregon } & 310.7 \\ \text { Indiana } & 254.7 \text { Pennsylvania } & 417.8 \\ \text { Iowa } & 586.3 \text { Rhode Island } & \text { (No record) } \\ \text { Kansas } & 271.6 \text { South Carolina } & 42.3 \\ \text { Kentucky } & 149.2 \text { South Dakota } & 297.8 \\ \text { Louisiana } & \text { (No record) } \text { Tennessee } & 161.8 \\ \text { Maine } & 256.6 \text { Texas } & 115.4 \\ \text { Maryland } & 201.5 \text { Utah } & 286.9 \\ \text { Massachusetts } & 142.2 \text { Vermont } & \mathbf{1 1 1 2 . 6} \\ \text { Michigan } & 415.1 \text { Virginia } & 145.6 \\ \text { Minnesota } & 791.3 \text { Washington } & 321.2 \\ \text { Mississippi } & 104.7 \text { West Virginia } & \text { (No record) } \\ \text { Missouri } & 188.8 \text { Wisconsin } & 740.0 \\ \text { Montana } & 157.4 \text { Wyoming } & 179.8\end{array}$

Average Number of Pounds of Butter Per Cow Produced in 1909

Alabama

Arizona

Arkansas

California

Colorado

Connecticut

Delaware

Florida

Georgia

Idaho

Illinois

Indiana

Iowa

Kansas

Kentucky

Louisiana

Maine

Maryland

Massachusetts

Michigan

Minnesota

Mississippi

Missouri

Montana
(No record) Nebraska

47.8 Nevada

71.0 New Hampshire

112.5 New Jersey

84.3 New Mexico

44.3 New York

61.3 North Carolina

14.6 North Dakota

67.0 Ohio

68.3 Oklahoma

67.7 Oregon

86.6 Pennsylvania

83.4 Rhode Island

65.6 South Carolina

94.3 South Dakota

(No record) Tennessee

98.2 Texas

59.0 Utah

30.5 Vermont

112.0 Virginia

113.8 Washington

66.8 West Virginia

61.1 Wisconsin

53.2 Wyoming
81.3

85.0

67

28.4

(No record)

45.9

84.3

75.5

89.5

58.7

81.9

98.1

(No record)

68.1

62.5

100.2

66.2

82.0

133.3

75.2

96.9

(No record)

88.9

60.4 
All Cattle Per Square Mile in 1909

Alabama

Arizona

Arkansas

California

Colorado

Connecticut

Delaware

Florida

Georgia

Idaho

Illinois

Indiana

Iowa

Kansas

Kentucky

Louisiana

Maine

Maryland

Massachusetts

Michigan

Minnesota

Mississippi

Missouri

Montana

17 Nebraska

7 Nevada

19 New Hampshire

13 New Jersey

10 New Mexico

39 New York

26 North Carolina

14 North Dakota

18 Ohio

5 Oklahoma

43 Oregon

37 Pennsylvania

79 Rhode Island

37 South Carolina

24 South Dakota

16 Tennessee

7 Texas

23 Utah

20 Vermont

25 Virginia

28 Washington

21 West Virginia

36 Wisconsin

6 Wyoming

All Dairy Cows Per Square Mile in 1909

Alabama

Arizona

Arkansas

California

Colorado

Connecticut

Delaware

Florida

Georgia

Idaho

Illinois

Indiana

Iowa

Kansas

Kentucky

Louisiana

Maine

Maryland

Massachusetts

Michigan

Minnesota

Mississippi

Missouri

Montana
7.4 Nebraska

7.9

0.2 Nevada

7.9 New Hampshire

2.9 New Jersey

1.3 New Mexico

24.6 New York

17.4 North Carolina

1.9 North Dakota

6.8 Ohio

1.1 Oklahoma

18.5 Oregon

17.4 Pennsylvania

25.0 Rhode Island

8.9 South Carolina

10.1 South Dakota

5.5 Tennessee

4.7 Texas

13.6 Utah

20.6 Vermont

13.0 Virginia

13.0 Washington

9.1 West Virginia

12.3 Wisconsin

0.5 Wyoming
0.1

10.8

19.7

0.4

30.7

5.9

3.6

22.0

7.5

1.7

20.6

18.6

5.8

4.7

9.4

3.8

0.8

27.7

8.3

2. 6

9.6

26.2

0.3 


\section{CROP YIELDS}

Vermont has no reason to apologize for her crop yields when compared with those of other states, although it is true that more intensive cultivation and a wider use of scientific methods of agriculture would make Vermont farms still more fruitful. The following tables which show the average yield per acre, the average price per bushel, ton or pounds, and the average returns per acre for the period 1870-1909 and 1910-1912 for nine staple crops, both for Vermont and for the United States, taken from the United States census reports and crop statistics issued by the United States Department of Agriculture, show how far the Vermont average exceeds the United States average in almost every instance:

Average Yield, Price And Returns Per Acre of Staple Crops in United States And Vermont, 1870-1909

$$
\begin{aligned}
& \text { UNited STATES } \\
& \text { CORN }
\end{aligned}
$$

VERMONT

Average yield per acre.......

Average price $\ldots . . . \ldots \ldots$.

Average returns per acre ....

Average yield per acre....... Average price .............. Average returns per acre ....

Average yield per acre....... Average price .............. Average returns per acre ....

Average yield per acre....... Average price.......... Average returns per acre ....

Average yield per acre....... Average price ............ Average returns per acre ....

Average yield per acre....... Average price ............ Average returns per acre ....

Average yield per acre....... Average price.....$\ldots \ldots$. Average returns per acre ....

$25.2 \mathrm{bu}$. $\$ 0.408$ per bu. $\$ 10.281$

\section{WHEAT}

$12.9 \mathrm{bu}$.

$\$ 0.813$ per bu. $\$ 10.487$

$27.6 \mathrm{bu}$.

$\$ 0.322$ per bu.

$\$ 8.887$

$$
23.3 \mathrm{bu} \text {. }
$$

$\$ 0.551$ per bu. $\$ 12.838$

$$
\text { RYE }
$$$$
\text { 14. bu. }
$$$$
\$ 0.604 \text { per bu. }
$$$$
\$ 8.456
$$

\section{BARLEY}

OATS

$35.6 \mathrm{bu}$. $\$ 0.687$ $\$ 24.457$

$19.0 \mathrm{bu}$. $\$ 1.112$ $\$ 21.128$

$35.1 \mathrm{bu}$. $\$ 0.435$ $\$ 15.268$

$27.3 \mathrm{bu}$. $\$ 0.69$ $\$ 18.837$

$15.9 \mathrm{bu}$. $\$ 0.782$ $\$ 12.433$

\section{POTATOES}

83. bu. \$. 0.527 per bu. $\$ 43.741$

\section{BUCKWHEAT}

$16.5 \mathrm{bu}$

\$ 0.612 per bu.

$\$ 10.098$
$112.5 \mathrm{bu}$. $\$ 0.492$ $\$ 55.35$

21.9 bu. $\$ 0.572$ $\$ 12.526$ 
United States

VERMONT

H.AY

Average yield per acre.......

1.28 tons

1.15 tons

Average price...$\ldots \ldots \ldots$

$\$ 9.33$ per ton

$\$ 11.942$

$\$ 10.465$

A,verage returns per acre ....

Average yield per acre.......

$747.6 \mathrm{lbs}$.

TOBACCO

Average price .......... \$0.081 per lb.

$\$ 12.034$

Average returns per acre ... \$60.555

Average returns per acre for all crops

United States, $\$ 19.676$.

Vermont, $\$ 45.187$.

Average Yield, Price And Returns Per Acre of Staple Crops in United States And Vermont 1910-1912

United States

VERMIONT

CORN

Average yield per acre....... Average price ............. Aiverage returns per acre ....

Average yield per acre....... Average price ............ Average returns per acre ....

Average yield per acre....... Average price...$\ldots \ldots \ldots$. A'verage returns per acre ....

Average yield per acre....... Average price ............ Average returns per acre ...

Average yield per acre........ Average price ............ Average returis per acre ....

Average yield per acre....... Average price......$\ldots \ldots$. Average returns per acre ....

Average yield per acre....... Average price ............ Average returns per acre ....

Average yield per acre....... Average price....$\ldots \ldots \ldots$. Average returns per acre .... $26.9 \mathrm{bu}$.

$41.3 \mathrm{bu}$. $\$ 0.528$ per bu. $\$ 0.726$ per bu. $\$ 14.203$ $\$ 29.983$

$12.5 \mathrm{bu}$. $\$ 0.816$ per bu. $\$ 1.00$ per bu. $\$ 10.20$ $\$ 27.30$

$31.1 \mathrm{bu}$.

\section{OATS}

\$0.371 per bu. \$0.523 per bu. $\$ 11.538$

$\$ 20.875$

\section{BARLEY}

$24.4 \mathrm{bu}$. $\$ 0.65$ per bu. $\$ 0.766$ per bu. $\$ 15.86$ $\$ 24.588$

RYE

$16.1 \mathrm{bu} . \quad 20 \mathrm{bu}$. $\$ 0.736$ per bu. $\quad \$ 0.90$ per bu. $\$ 11.849$

$\$ 18.00$

96 . bu. 125 bu. $\$ 0.62$ per bu. $\$ 0.596$ per bu. $\$ 59.52$

$\$ 74.50$

21.5 bu. BUCKWHEAT $\$ 0.622$ per bu. $\$ 0.756$ per bu. $\$ 14.663$ $\$ 19.731$

\section{HAY}

1.32 tons $\$ 12.74$ per ton $\$ 16.816$

1.38 tons $\$ 13.46$ per ton $\$ 18.574$ 
United States

VERMONT

TOBACCO

Average yield per acre....... Average price .............

A'verage returns per acre ....

828.9 lbs.

1666.6 lbs. $\$ 0.098$ per lb. $\$ 0.163$ per lb. $\$ 81.232$

Average returns per a.cre for all crops 1910-1912

$\$ 271.655$

United States, \$26.209.

Vermont, $\$ 56.467$.

Value of all Crops Per Capita of Rural Population in 1909

\begin{tabular}{|c|c|c|c|}
\hline Alabama & $\$ 81.62$ & Nebraska & $\$ 222.52$ \\
\hline Arizona & $\$ 38.95$ & Nevada & $\$ 86.46$ \\
\hline Arkansas & $\$ 87.78$ & New Hampshire & 1.04 \\
\hline California & $\$ 168.65$ & New Jersey & \\
\hline Colorado & $\$ 129.31$ & New Mexico & \\
\hline onnecticut & $\$ 195.60$ & New York & $\$ 108$ \\
\hline Delaware & $\$ 86.66$ & North Carolina & \\
\hline lorida & $\$ 67.73$ & North Dakota & $\$$ \\
\hline eorgia & $\$ 109.44$ & Ohio & \\
\hline gl & $\$ 134.36$ & Oklahoma & $\$$ \\
\hline linois & $\$ 172.21$ & Oregon & $\$ 1$ \\
\hline diana & $\$ 130.50$ & Pennsylvania & \\
\hline wa & $\$ 203.70$ & Rhode Island & \\
\hline ansas & $\$ 179.47$ & South Carolina & $\$$ \\
\hline $\mathrm{ky}$ & $\$ 80.24$ & South Dakota & \\
\hline iana & $\$ 66.67$ & Tennessee & d \\
\hline Main & $\$ 108.93$ & Texas & $\$ 42$. \\
\hline aryland & & Utah & $\$ 92.23$ \\
\hline usetts & $\$ 132.53$ & Ver & $\$ 146$. \\
\hline an & $\$ 74.94$ & Virginia & \\
\hline innesota & $\$ 157.88$ & Washington & $\$ 14$ \\
\hline ssippi & 92.66 & West Virginia & 40.6 \\
\hline & & Wisconsin ... & 11 \\
\hline ontana & 46 & Wyoming & \\
\hline
\end{tabular}

\section{Vermont And Iowa Compared}

Director of the Census Durand said in a recent magazine article that Iowa, perhaps, is the greatest farming state in the Union, and that Iowa is second to Illinois in value of farm products, yet Iowa is more typically an agricultural state. This statement being made on such high authority, it may be of interest to compare crop yields and crop values in Vermont with those of Iowa. The first comparison will be for the forty-year period, 1870 to 1909, inclusive.

Iowa

Average yield per acre ......

Average price

Average returns per acre
32 bu.

$\$ 0.302$ per bu.

$\$ 9.664$
VERMONT

CORN

$35.6 \mathrm{bu}$.

$\$ 0.687$ per bu. $\$ 24.457$ 


\section{.}

IowA

VERMIONT

Average yield per acre .......

Average price ............

Average returns per acre ....

Average yield per acre .......

Average price ............

Average returns per acre ....

Average yield per acre ......

Average price ............

Average returns per acre....

Average yield per acre ...... Averags price ............

Average returns per acre ....

Average yield per acre ...... Average price ............

Average returns per acre ....

Average yield per acre ..... Average price ............ Average returns per acre ....

Average yield per acre ..... Average price ............ Average returns per acre ....

Average returns per acre for eight staple crops mentioned.

WHEAT

$12.6 \mathrm{bu}$. 19 . bu. $\$ 0.697$ per bu. $\quad \$ 1.112$ per bu. $\$ 8.782$ $\$ 21.128$

$31.8 \mathrm{bu}$. OATS

$\$ 0.247$ per bu. $\$ 0.435$ per bu. $\$ 7.854$

\section{BARLEY}

$23.8 \mathrm{bu}$. $\$ 0.425$ per bu. $\$ 0.69$ p 27.3 bu. $\$ 10.115$ per bl. $\$ 0.69$ per bu. RYE

$16.3 \mathrm{bu}$.

$\$ 0.472$ per bu. $\$ 0.782$ per bu. $\$ 7.693$

82.2 bu. POtatoes $112.5 \mathrm{bu}$. $\$ 0.455$ per bu. $\$ 0.492$ per bu. $\$ 37.401$

$\$ 55.35$

\section{BUCKWHEAT}

14.4 bu. $21.9 \mathrm{bu}$. $\$ 0.665$ per bu. $\$ 0.572$ per bu. $\$ 9.576$ $\$ 12.526$

HAY

1.39 tons $\quad 1.15$ tons $\$ 5.61$ per ton $\$ 10.465$ per ton $\$ 7.797 \quad \$ 12.034$ Iowa, $\$ 12.36$.

Vermont, $\$ 21.504$.

The following comparisons are for the years since 1909.

IowA

VERMONT

Yield per acre in $1912 \ldots \ldots \ldots$ Average yield per acre in 19091912

43. bu. CORN

$36.8 \mathrm{bu}$. 40. bu. Average returns per acre ..... Price paid farmers Dec. 1, 1912 Average price paid 1909-1912

Yield per acre in 1912

15.89

$41 \mathrm{bu}$. $\$ 0.35$ per bur $\$ 0.72$ per bu $\$ 0.35$ per bu. $\$ 0.72$ per bu. $\$ 0.432$ per bu. $\$ 0.727$ per bu. 17. bu. 16.1 bu. $\$ 13.84$ $\$ 0.78$ per bu. $\$ 0.86$ per bu.

1912 . . . . . . . . . . . .

Average returns per acre ....

Price paid farmers Dec. 1, 1912 Average price paid 1909-1912 25. bu.

24. bu.

\section{SPRING WHEAT}

$\$ 25.20$

$\$ 0.98$ per bu. $\$ 1.05$ per bu. 
IowA

Yield per acre in $1912 \ldots . \ldots$. Average yield per acre in 19091912

Average returns per acre ...... Price paid farmers Dec. 1, 1912 Average price paid 1909-1912

Yield per acre in 1912

Average yield per acre in 19091912

Average returns per acre .... Price paid farmers Dec. 1, 1912 Average price paid 1909-1912

Yield per acre in $1912 \ldots . .$. . Average yield per acre in 19091912

Average returns per acre .... Price paid farmers Dec. 1, 1912

Yield per acre in 1912 ....... Average yield per acre in 19091912

Average returns per acre.... Price paid farmers Dec. 1, 1912 Average price paid 1909-1912

Yield per acre in 1912

Average yield per acre in 19091912

Average returns per acre ....

Price paid farmers Dec. 1, 1912 . . Average price paid 1909-1912..

Yield per acre in 1912 ...... Average yield per acre in 19091912

Average returns per acre .... Price paid farmers Dec. 1, 1912 Average price paid 1909-1912 Average price paid 1909-1912

31. bu.

BARLEY

25.4 bu.

$\$ 15.54$

$\$ 0.52$ per bu. $\$ 0.612$ per bu. $\$ 0.767$ per bu. RYE

19. bu.

20. bu.

$17.2 \mathrm{bu}$. $\$ 11.43$

$\$ 0.62$ per bu. $\$ 0.665$ per bu. $\$ 0.925$ per bu. BUCKWHEAT

19. bu.

30. bu.

16.1 bu.

$25.2 \mathrm{bu}$. $\$ 13.39$

$\$ 19.07$

$\$ 0.75$ per bu. $\$ 0.72$ per bu. $\$ 0.832$ per bu. $\$ 0.757$ per bu. POTATOES 109. bu.

140. bu.

$85.5 \mathrm{bu}$.

$132.2 \mathrm{bu}$. $\$ 50.01$

$\$ 73.63$ $\$ 0.46$ per bu. $\$ 0.55$ per bu. $\$ 0.585$ per bu. $\$ 0.557$ per bu. OATS

44.2 bu.

43. bu.

$33.7 \mathrm{bu}$.

$\$ 10.95$

$\$ 0.27$ per bu. $\$ 0.325$ per bu. $\$ 0.517$ per bu. $37.3 \mathrm{bu}$. $\$ 19.28$ 1.40 tons HAY 1.50 tons 1.19 tons $\$ 11.51$ $\$ 9.50$ per ton 1.30 tons $\$ 17.90$ 14.00 per ton $\$ 9.675$ per ton $\$ 13.775$ per ton

\section{Other Comparisons}

The following are a few comparisons of Vermont crop yields and crop values with those of a few of the leading agricultural states of the Middle West, in addition to the Iowa comparisons: 


\section{VERMONT}

(1870-1909)

Corn ............

Wheat .........

Oats ..............

Barley ...........

Rye ............

Potatoes ........

Buckwheat .......

Hay ............

Tobacco ........ 1533.7 lbs.
AVERAGE PRICE AVERAGE RETURNS

PER ACRE

$\$ 24.457$

$\$ 21.128$

$\$ 15.268$

$\$ 18.837$

$\$ 12.433$

\$ 55.35

$\$ 12.526$

$\$ 12.034$

$\$ 234.656$

\section{Оніо}

(1870-1909)

AVERAGE YIELD AVERAGE PRICE PER ACRE

Corn ...........

Wheat .........

Oats ..........

Barley ..........

Rye ............

Potatoes

Buckwheat ......

Hay ...........

Tobaceo

$33.4 \mathrm{bu}$.

$14.2 \mathrm{bu}$.

30.7 bu.

$24.7 \mathrm{bu}$.

14.5 bu.

75. bu.

$14.5 \mathrm{bu}$.

1.24 tons

849. lbs.
$\$ 0.412$ per bu. $\$ 0.89$ per bu. \$ 0.317 per bu. $\$ 0.617$ per bu. $\$ 0.61$ per bu. $\$ 0.552$ per bu. $\$ 0.687$ per bu. $\$ 9.905$ per tón $\$ 0.073$ per lb.
AVERAGE RETURNS PER ACRE

$\$ 13.76$

$\$ 12.639$

$\$ 9.731$

$\$ 15.239$

$\$ 8.845$

$\$ 41.40$

$\$ 9.861$

$\$ 12.282$

$\$ 61.977$

\section{INDIANA}

(1870-1909)

AVERAGE YIELD AVERAGE PRICE PER ACRE

Corn ...........

Wheat ..........

Oats ............

Barley ...........

Rye ............

Potatoes ..........

Buckwheat .......

Hay ..........

Tobacco $31.8 \mathrm{bu}$. \$ 0.367 per bu.

AVERAGE RETURNS $13.4 \mathrm{bu}$. $\$ 0.85$ per bu. 27.4 bu. $\quad \$ 0.297$ per bu. 22.8 bu. $\quad \$ 0.612$ per bu. 13.7 bu. $\quad \$ 0.585$ per bu. PER ACRE $69.7 \mathrm{bu}$. $\quad \$ 0.552$ per bu. $\$ 11.67$ $\$ 11.39$ \$ 8.137 $\$ 13.953$ $\$ 8.014$ 14.3 bu. $\quad \$ 0.667$ per bu. $\$ 38.474$ $\$ 9.528$ 1.28 tons $\$ 9.037$ per ton $\$ 11.567$ 728 lbs. $\$ 0.066$ per lb. 


\section{ILLINOIS}

(1870-1909)

\begin{tabular}{|c|c|c|c|}
\hline & AVEF & AYERAGE PRICE & AVERAGE RETURNS \\
\hline & PER ACRE & & PER ACRE \\
\hline Corn & $30.8 \mathrm{bu}$. & $\$ 0.347$ per bu. & $\$ 10.687$ \\
\hline Wheat & $13.6 \mathrm{bu}$. & $\$ 0.81$ per bu. & $\$ 11.016$ \\
\hline Oats .. & $31.2 \mathrm{bu}$. & $\$ 0.277$ per bu. & 8.642 \\
\hline Barley & 23.8 bu. & $\$ 0.542$ per bu. & $\$ 12.899$ \\
\hline Rye. . & $16.1 \mathrm{bu}$. & $\$ 0.542$ per bu. & $\$ \quad 8.726$ \\
\hline Potatoes ......... & $75.2 \mathrm{bu}$. & $\$ 0.575$ per bu. & $\$ 43.24$ \\
\hline Buckwheat. & $13.6 \mathrm{bu}$. & $\$ 0.692$ per bu. & $\$ 9.411$ \\
\hline Hay ....... & 1.30 tons & $\$ 8.285$ per ton & $\$ 10.77$ \\
\hline Tobacco ..... & 676.7 lbs. & $\$ 0.075$ per lb. & $\$ 50.725$ \\
\hline
\end{tabular}

CORN

The old days when cotton was king of American crops passed long ago. Today corn is king, with no rival to dispute his right to reign. Even in the South, where cotton was raised almost exclusively for many years, corn is now one of the principal crops, and some of the leading corn growing states of the Union are found in the South. People have become accustomed to the idea that corn can be grown successfully only in the Middle West. This idea is erroneous, and there are facts in abundance to prove this assertion.

The Boston Transcript recently said: " "Till Birnam Wood shall come to Dunsinane' was intended to phrase the immovability of rooted, growing things. Yet Birnam Wood came to Dunsinane for all that. And when we speak of the great 'corn belt' as being in the Mississippi valley, as we have habitually done for several decades, it does not banish the possibility of the corn belt moving eastward, if not in the ratio of productivity per acre. This curious process has, in fact, begun. The New Englander migrated to the Middle West and applied himself to the business of corn raising. Now the business of corn raising is migrating back to New England.

"This gradual and significant increase in New England's yield per acre of corn is the more curious to watch, inasmuch as we have been so long accustomed to think of corn in terms of the Middle West. Yet the Government erop reports of recent years show with all the precision of a geometrical theorem the increased and increasing yield within our own region until as long ago as 1910 the average yield per acre in the New England States was forty-six bushels, as against thirth-nine bushels per acre in Illinois and thirty-six bushels per acre in Iowa, long reputed to be the two leading states of the Middle West in the production of corn. What is more, the yield per acre in New England is steadily increasing; which brings us to the economic strategies of fertilizer. For when these rich Middle Western farms were new and needed no fertilizer, the leaner land of our New England 
farms, which required dressing, could not compete. Within the last five years, however, Illinois has begun to use fertilizer (in common with other Mississippi states), which means that the farms of New England are once more on a competitive footing. They are more. They are close to the big Eastern markets and they are on the cisAlpine side of the expensive freight haul over the Berkshire range. As lately as three years ago the average worth to a Maine farmer of an acre of corn was $\$ 32$, as against $\$ 13.07$ in Iowa. A large part of this difference lay in freight, some of it was to be accounted for by a surplus of production in Iowa and a part by Maine's proximity to the markets; but the tendency is a fact and a significant one."

The same logic applies to conditions in Vermont. Last year the average yield of bushels of corn per acre was the same in both Vermont and Maine. The scientists say that corn is a sub-tropical plant which possesses a quality peculiar to every variety to thrive best near the northern limits of its possible growth. It is certain that in recent years New England has been leading the United States in bushels of corn per acre.

The story which government statistics tell concerning corn yields and prices in Vermont is both interesting and significant. Last year (1912) only eight states raised more bushels of corn per acre than Vermont. In 1911 the Vermont corn yield per acre was exceeded by six states, in 1910 by four states, in 1909 by six states. For a period of four years the average number of states raising more bushels of corn per acre than Vermont was only six. During these years Illinois and Iowa have led the Union in quantity of corn produced. Only once during this period has Illinois equaled the Vermont yield and only once has Iowa equaled or surpassed it. In 1912 Vermont's average yield was forty bushels per acre, while that of the United States was 29.2 bushels. In 1911 the Vermont average was 41 bushels and that of the United States 23.9 bushels. 1910 the Vermont average was 43 bushels and the United States average 27.7 bushels. In 1909 Vermont produced an average yield of 40 bushels, compared with an average vield of 25.9 bushels for the United States. Vermont's average yield for the four-year period is 41 bushels, while the United States shows an average of 26.6 bushels, or only a little more than half Vermont's average. Compared with Vermont's four-year average of 41 bushels per acre, Kansas shows an average vield for the period of 18.9 bushels; Nebraska, 23.9 bushels; North Dakota, 23.1 bushels; Oklahoma, 11.7 bushels; South Dakota, 26.2 bushels.

The average price paid farmers for corn December 1st for the past four years was $\$ 0.777$ in Vermont, and $\$ 0.541$ for the entire country.

As already shown, Vermont led the Union in bushels of corn per acre for the forty-year period, 1870 to 1909-not every year, but the Vermont average was the highest for the entire period. Vermont's average yield for the forty-year period was 35.6 bushels, compared 
with an average of 25.2 bushels for the United States as a whole. The average price to farmers December 1st for the period was $\$ 0.687$ per bushel in Vermont and $\$ 0.408$ per bushel for the entire country. The average returns of corn land per acre for the period was $\$ 24.457$ in Vermont and less than half as much, or $\$ 10.281$ for the whole country.

These facts are indisputable proof that Vermont can raise more bushels of corn per acre than most of the states of the Union, and that prices paid in Vermont are larger than in most sections of the country. Of course the New England farms are smaller than many of those of the West, and for a considerable period corn is not likely to be raised in this section in any considerable quantity for shipment. The New England states with such a record of crop yield ought to raise their own corn, and yet in 1910 this group of states bought 11,000,000 bushels of corn from the West. There are great opportunities in Vermont for raising corn for feeding purposes, thus avoiding the large expense of buying stock foods, and at the same time maintaining and building up the fertility of the soil. For several years a State Corn show has been held at Windsor, Vt., in the big riding arena owned by F. A. Kennedy of New York, under the auspices of the Windsor County Y. M. C. A. Another State Corn Show will be held here November 5-7, 1913, and an attempt will be made to have the New England Corn Show held here in 1914. The last Legislature appropriated $\$ 500$ for this purpose.

'The Windsor County Y. M. C. A. has organized boys' corn clubs which have done excellent work. The Y. M. C. A. has purchased prize winning corn that it might be able to furnish high grade seed for the contests. An eighth of an acre was the size of each corn plot. These contests have stimulated both the boys and the boys' fathers to adopt better agricultural methods. Twenty bushels of ears of corn have been raised on an eighth of an acre, at the rate of 160 bushels to the acre. The experts of the Illinois College of Agriculture average only 87 bushels to the acre. One father, who had sold his farm, purchased it again as a result of his son's interest and success in corn growing. One boy missed his train and walked nineteen miles to be present in time for the judging of his corn exhibit. One mother, seeing her boy's interest in corn growing, saved her butter money to send him to the State Agricultural School.

J. Wade Webster of Hartland, Vt., won the sweepstakes prize for the best single ear of corn grown by boys in Vermont, New Hampshire or Maine at the New England Corn Exposition, held at Boston in 1912.

A North Clarendon farmer for several years has been growing and selling seed corn of the flint varieties and he has supplied customers in South Africa, Central and Northern Europe and the British Isles. Not long ago he received an order for 25,000 bushels packed for export.

The outlook is encouraging for more intensive corn growing and 
with Vermont's possibilities already demorstrated, the state offers great opportunities for the profitable growing of this staple erop.

\section{WHEAT}

Probably the average reader would expect that an article on wheit growing in Vermont would require about as much space as that taken by the famous chapter on "Snakes in Ireland." It is necessary, however to shatter another erroneous impression. Although wheat is not grown on a large scale in Vermont, spring wheat is grown here, as every issue of the Government Crop Reporter, containing crop yields, will show, and Vermont's rank is way up near the top of the list. Last year only five states, and every one of these states in the irrigated region of the Far West, surpassed Vermont in the yield of spring wheat per acre. Vermont's four-year average for the years 1909-1912 was 24 bushels, while the average yield for the entire United States for the same period was 13.2 bushels. North Dakota raises more spring wheat than any other State. 'The average yield in that State for the past four years was 11.3 bushels, or less than half the Vermont average. Other States that approach North Dakota in the amount of spring wheat raised are Minnesota and South Dakota. Minnesota's four-year averag'e was 14.7 bushels and that of South Dakota 11.4 bushels.

The census reports for the forty-year period, 1870-1909, show that only two states surpassed Vermont in yield of number of bushels of wheat per acre for that time. Vermont's arerage was 19 bushels and the average for the entire country was 12.9 bushels.

The average price to farmers in Vermont Dee. 1 for the four-year period, 1909-1912, was $\$ 1.05$ per bushel, and in the United States at large the price for that period was $\$ 0.844$ per bushel. The average price in North Dakota for this period was $\$ 0.85$ per bushel; in Ninnesota, $\$ 0.887$ per bushel; in South Dakota, $\$ 0.847$ per bushel. The average price in Vermont for the forty-year period, 1870-1909, was $\$ 1.112$ per bushel while the average price for the entire United States for the same period was $\$ 0.813$ per bushel. The average returns from an acre of wheat land in Vermont for the period, 1870-1909, amounted to $\$ 21.128$, and in the whole country for the same forty-year period, $\$ 10.487$, or less than half the Vermont average.

In a recent issue the Country Gentleman said: "Trrioation farming to be successful must always be in the nature of intensive farming. Forty acres is about the maximum of acreage that one farmer can operate properly. This is the judgment of experience. Intensive wheat farming is practiced in a number of the humid states. Of those which have small areas in wheat, Vermont takes the front place. In 1909 the Department of Agriculture received reports from five wheat farmers in the Green mountain state, each growing about eight acres. (Of course this does not mean that these five farmers are the only ones who raise wheat. This refers to special reports made by these 
particular farmers.) The expense is quite high. The Vermont wheat farmer of this type expends more for fortilizer than the total cost of the entire crop in Nebraska, excluding land interest. His fertilizer bill is $\$ 6.75$ an acre; he spends $\$ 3.00$ for preparing the ground which again is twice as much as the Nebraska wheat farmer spends for the same purpose. The Vermonter spends $\$ 2.75$ for seed, while the Nebraskan spends but $\$ 1.28$ and the Wyoming man $\$ 1.45$; it costs the Vermont man $\$ 1.31$ to plant his acre of wheat, the Illinois man $\$ 0.35$, the Nebraskan $\$ 0.44$, the Minnesotan $\$ 0.42$.

"And so the items of expense run-from two to three times as much in Vermont as in the other wheat states where intensive wheat growing is not practiced until it gets to the item of land rent or interest on the value of the land. The Vermont wheat land is valued at $\$ 50$ an acre, approximately the same as in Minnesota; less than half as much as in Illinois, 50 per cent less than in Nebraska.

"And when the Vermont small wheat grower has figured up his total he finds he has spent $\$ 23$ to grow an acre of wheat, but when he harvests his crop he gets 36.2 bushels which he sells at the rate of $\$ 1.18$, or a total of $\$ 42.71$. And when he figures his net profit he finds he has made $\$ 19.71$ an acre; $\$ 157.68$ on his eight acre wheat patch on land valued at $\$ 450$. That same year the Illinois man made $\$ 145$ from 27 acres of wheat on land valued at $\$ 3,046$; the Minnesotan made $\$ 276.32$ on 44 acres valued at $\$ 2,150$; the irrigationist in Wyoming or Nebraska made $\$ 188$ from 21 acres valued at $\$ 2,100$; the $\mathrm{Ne}$ braska-humid region-wheat farmer made $\$ 240$ on 40 acres valued at $\$ 2,981$. The Vermont man's returns are at the rate of 35 per cent of the land value."

The writer in the Country Gentleman might have drawn other interesting lessons from these figures. He seems inadvertantly to have made one or two errors. Of course eight acres at $\$ 50$ an acre would be valued at $\$ 400$ instead of $\$ 450$. If the returns from an acre of Vermont wheat land were $\$ 19.71$ and the value of the land was $\$ 50$ an acre, then the returns would be at the rate of 39.4 per cent rather than 35 per cent. It will be seen that the returns per acre from Illinois wheat land amounted to $\$ 5.37$ and that the Vermont farmer received more from his eight acres than the Illinois grower did from his 27 acres. It will be seen that the returns per acre for Minnesota amounted to $\$ 6.28$; it will be seen that the irrigationist in Wyoming and Nebraska made $\$ 8.95$ per acre, and the wheat grower in the humid region of Nebraska, $\$ 6.00$ per acre. The Illinois wheat lands were valued at $\$ 112.44$ per acre and the returns were at the rate of 4.7 per cent on the land value. The value of the wheat lands of Minnesota according to these figures would be $\$ 48.86$ per acre, and the returns at the rate of 12.8 per cent of the land value. The value of wheat lands in the irrigated regions of Wyoming and Nebraska would be $\$ 100$ an acre and the returns 8.95 per cent of the land value. The land in the humid region of Nebraska, according 
to these figures, is worth $\$ 74.52$ an acre and the returns would be slightly more than eight per cent of the land value. Compared with the returns of nearly 40 per cent on the land value shown on the Vermont wheat land one may get an idea of the productiveness of Vermont soil.

While most of the wheat grown in Vermont is spring wheat, occasionally a crop of winter wheat is grown. Last year a Woodstock farm had three acres of winter wheat which produced an average of 43 bushels per acre. A letter from the Superintendent of the Vermont State Industrial School at Vergennes states that for several years from 40 to 42 bushels of wheat per acre have been raised on the farm owned by that institution. This letter, however, does not state whether the wheat was spring or winter variety. Last year the average yield per acre of winter wheat in the United States was 15.1 bushels. The greatest winter wheat growing States are Kansas, Nebraska and Washington. Their average yields last year were: Kansas, 15.5 bushels; Nebraska, 18 bushels; Washington, 27.6 bushels. Evidently Vermont can hold her own in wheat growing if she cares to undertake to raise that crop.

\section{OATS}

During the forty-year period, 1870-1909, inclusive, Vermont's average yield of bushels of oats per acre was the largest of any state in the Union. Last year only eight states surpassed Vermont in number of bushels of oats per acre. In 1911 nine states raised more oats per acre than Vermont. In 1910 five states surpassed the Vermont yield, and in 1909 seventeen states reported more bushels of oats per acre than Vermont.

Vermont's average yield for the past four years was 37.3 bushels per acre while the average for the United States for the same period was 30.5 bushels per acre. Vermont's average yield for the period, 1870-1909, was 35.1 bushels per acre, while the average for the United States for the forty years mentioned was 27.6 bushels per acre.

The states producing the largest number of bushels of oats per acre in recent years are Iowa, Illinois, Minnesota, North Dakota, and Ohio. The average yield of oats per acre of these states during the past four years was as follows: Iowa, 33.7 bushels; Illinois, 36.5 bushels; Minnesota, 31.1 bushels; North Dakota, 35.6 bushels; Ohio. 36.4 bushels. Not one of these states equals Vermont's average.

The average Vermont price to farmers Dec. 1 for the four-year period, 1909-1912, was 51.7 cents. The average price for the period throughout the United States was 37.8 cents. The average price per bushel during the last four years in the states producing the largest number of bushels of oats was as follows: Iowa, 32.5 cents; Illinois, 35 cents; Minnesota, 33.3 cents; Ohio, 38.5 cents. Vermont's price was far better than that paid by any of these states. For the forty-year period, 1870-1909, the average Vermont price was 43.5 cents per bushel, while the average price for the whole country was 32.3 cents per bushel. 


\section{BARLEY}

In 1912 only seven states, and all of them in the irrigated region in the Far West, raised more bushels of barley per acre than Vermont. In 1911 eight states surpassed Vermont in kushels of barley per acre, while in 1910 six states, and in 1909 eight states raised more bushels per acre of barley than Vermont. Vermont's four year average was 30.8 bushels, while that of the United States was 23.9 bushels. The great barley growing states of the Union are California, Minnesota, North Dakota, South Dakota and Wisconsin. These states produced an average yield per acre for the past four years as follows: California, 27.7 bushels; Minnesota, 22.6 bushels; North Dakota, 19.1 bushels; South Dakota, 17.4 bushels; Wisconsin, 26.9 bushels. Vermont easily outranked all of these states.

Vermont's average yield of barley for the forty years from 1870 to 1909 was 27.3 bushels, and the average for the United States for that period was 23.3 bushels. During that period only four states showed a larger yield per acre than Vermont.

The average price paid to farmers Dec.1 for the four-year period, 1909-1912, was 76.7 cents per bushel in Vermont, 62.3 cents for the United States as a whole. The average price paid in the leading barley growing states was as follows: California, 71 cents; Minnesota, 61 cents; North Dakota, 54.5 cents; South Dakota, 58 cents, Wisconsin, 58.5 cents. The Vermont price again exceeds not only that of the United States but also that of the states growing the largest amount of barley. The average Vermont price for the forty-year period, 18701909 , was 69 cents per bushel, and the price for the United States for the same was 55.1 cents per bushel.

\section{RYE}

Last year only three states raised more bushels of rye per acre than Vermont. In 1911 only one state surpassed Vermont in this respect, in 1910 nine states, and in 1909 six states. Vermont's four-year average yield was 19.2 bushels per acre and that of the United States for the same period, 12.9 bushels per acre.

The great rye growing states are Wisconsin, Minnesota, Michigan and Pennsylvania. The four-year average yield of these states was as follows: Wisconsin, 16.3 bushels; Minnesota, 18.8 bushels; Michigan, 14.2 bushels; Pennsylvania, 15.6 bushels. Vermont's average yield for the forty-year period, 1870-1909, was 15.9 bushels per acre, while the average for the United States for the same period was 14 bushels per acre. Only five states surpassed Vermont during this forty-year period in bushels of rye per acre. Vermont does not suffer by any of these comparisons.

The average price paid to Vermont farmers December 1 for the four-year period, 1909-1912, was 92.5 cents per bushel. The average price for that period throughout the United States was 73.2 cents per 
bushel. The average price paid in the leading rye growing states for the period mentioned was as follows: Wisconsin, 71 cents per bushel; Minnesota, 63 cents per bushel; Michigan, 71.7 cents per bushel; Pennsylvania, 77.5 cents per bushel. The average price per bushel paid in Vermont for the forty-year period, 1870-1909, was 78.2 cents and the average in the United States for the same period was 60.4 cents.

\section{BUCKWHEAT}

In 1912 only one state surpassed Vermont in bushels of buckwheat per acre. In 1911 two states had a larger yield per acre, in 1910 two states, and 1909, one state. Vermont's four-year average, 1909-1912, was 25.2 bushels per acre. The average yield for the entire country for that period was 20.3 bushels per acre. The great buckwheat growing states of the Union are Pennsylvania and New York and their average yield for the period mentioned was as follows: Pennsylvania, 20.5 bushels per acre; New York, 22 bushels per acre. Vermont's average yield for the forty-year period, 1870-1909, was 21.9 bushels, and that of the whole country was 16.5 bushels per acre. Only one state in the Union during this period surpassed Vermont in yield per acre.

The average Vermont price to farmers December 1 for the period 1909-1912 was 75.7 cents per bushel, and that of the entire United States 68.7 cents per bushel. For the same period the price in Pennsylvania was 65.7 cents and in New York was 67.7 cents.

Vermont ranks with the best in ability to furnish the raw material for buckwheat cakes and the maple syrup with which to sweeten them.

\section{POTATOES}

During the forty-year period, 1870-1909, only two states showed a larger average yield of bushels of potatoes per aere than Vermont. In 1912, only seven states, all of them, with the single exception of Naine, in the irrigated region of the West, surpassed Vermont in bushels of potatoes per acre. In 1911 thirteen states surpassed Vermont in this respect, in 1910 seven states, and in 1909, five states. Termont's average yield per acre for the four-year period, 1909-1912, was 132.2 bushels while the average vield for the United States for the same period was 98.5 bushels.

The great potato growing states so far as aggregate amount of bushels produced is concerned are New York, Michigan, Wisconsin and Minnesota, in the order named. 'The average yield per acre in these states for the period 1909-1912 was as follows : New York 101.2 bushels; Michigan, 102.2 bushels; Wisconsin, 110.2 bushels; Minnesota, 107.7 bushels. Maine ranks fifth in the number of bushels produced, but in yield per acre is in a class by itself, showing an average yield for the four-year period mentioned of 202 bushels per acre. Thus Vermont is surpassed only by Maine of all the big potato growing states in yield per acre. The average Vermont yield for the forty-year period, 1870- 
1909, was 112.5 bushels, and for the United States for that period was 83 bushels.

Owing partly to the new lands of Aroostook county, and partly to scientific culture Maine has been able to take first place in yield of potatoes per acre, but Vermont affords wonderful opportunities for potato growing, and if the same methods are employed in Vermont that have proved so successful in Maine, there are large areas in which equally as good results may be achieved.

The fact that some of the best known varieties of potatoes bear Vermont names, like "Green Mountain" and "Pride of Vermont," indicate that this state is naturally associated with the growing of good potatoes. C. G. Pringle of Charlotte, Vt., one of the most famous of American botanists, many years ago originated the Snowflake potato. $\mathrm{He}$ also originated the hulless oat, which made possible the production of certain popular cereal products, and Defiance wheat, which for many years was the staple product of some of the larger wheat fields of the West. It is said that Mr. Pringle gave Luther Burbank his first impulse to originate new varieties of plants.

One of the large commercial fertilizer companies last year offered seven prizes for the largest yields of best quality, table-size potatoes. The second prize was awarded to George E. Burditt of Rochester, Vt., who raised 527.2 bushels from one acre, 73.5 per cent being of table size, 14.9 per cent being judged too large, and 11.6 per cent too small. In cooking qualities they scored 49 out of a possible 50 points. Mr. Burditt's yield was only 18.2 bushels below the yield of the Maine man who eaptured the first prize. Mr. Burditt is a young man, just beginning farming, and recently completed the short course in agriculture at the University of Vermont.

A recent report of the Vermont Department of Agriculture shows rhat an acre of Gold Coin potatoes raised in the northern part of the state yielded 360 bushels, which sold at fifty cents per bushel. The cost of ploughing, fitting the land, planting seed, fertilizer, tillage, spraying six times, digging and rent of land, amounted to $\$ 79$, leaving a net profit of $\$ 101$ for the acre of potatoes. This farmer also raises large quantities of seed potatoes for the Virginia market.

In this connection it is interesting to note that this farmer, who is Hon. E. S. Brigham, now Commissioner of Agriculture, entered upon this line of business in a way that is a compliment to himself and a credit to the State of Vermont. H. W. Collingwood, in the Rural New Yorker, of which he is editor, recently published an illustrated article on this subject, in which he said: "You would hardly say that the man shown in the picture is making history-would say he is spraying potatoes. The fact is he is doing both. When you prove that Northern Vermont has the peculiar elimate and soil needed to grow superior seed potatoes you make history. It is much like proving that the islands of the English Channel produce superior butter cows, that the shores of the Mediterranean Sea produced laying hens, or 
that around Northern France are to be found superior draft horses.

"A few years ago a group of Southern farmers and truckers, who planted large quantities of potatoes, went hunting for strong and vital seed. There was great damage from blight, which disease was peculiarly bad in their section. *** These planters wanted, if possible, seed from plants that never had the disease. 'They asked the Department of Agriculture to locate a seetion where there was least potato blight. Then they wanted a farmer to try growing seed. The agent of the department suggested E. S. Brigham, who lives near St. Albans, Vt. It cannot be said that there is no potato blight in this part of Northern Vermont, but it is infrequent, and in favored localities, with proper spraying, large areas of potatoes may be developed with no trace of the disease."

The article then proceeds to describe the methods of eulture, which description does not properly find a place in this book, the important fact being that the United States Department of Agriculture recognized Vermont as a region superior to all others for the raising of good seed potatoes, free from all taint of blight. This is a fact not to be ignored by farmer's who are weighing the merits of various agricultural regions.

Experts have declared that the White River valley was as well adapted to potato raising as Aroostook county, Maine. The White River Railroad Company recently offered prizes for the best potatoes grown along this line and the winner of the first prize raised 467.4 bushels from an acre. Good potato growing soil, however, is limited to no particular section of the state, and when Aroostook county methods are employed, Arootstook county yields wili be secured in almost any part of Vermont.

\section{$\mathrm{HAY}$}

Last year fifteen states surpassed Vermont in tons of hay per acre. In 1911 fourteen states surpassed Vermont in this respect; in 1910, twenty-one states; in 1909, thirty-two states. Vermont's four-year average yield was 1.30 tons per acre, while the average throughout the United States for the period was 1.33 tons per acre. The great hay growing states are New York, Towa, Pennsylvania, Missouri and Ohio. The average four-year yield for these states was as follows: New York, 1.16 tons; Iowa, 1.19 tons; Pennsylvania, 1.22 tons; Miss. ouri, 1.07 tons; Ohio, 1.25 tons. The average yield per acre for Vermont for the forty-year period, 1870-1909, was 1.15 tons. The average yield for the United States for that period was 1.28 tons.

The average Vermont price to farmers December 1 for the fouryear period, $1909-1912$, was $\$ 13.77$ per ton. The average price in the United States for the period was $\$ 12.18$ per ton. The average price of this period in the great hay growing states was as follows: New York, $\$ 15.17$; Iowa, $\$ 9.67$; Pennsylvania, $\$ 16.30$; Missouri, $\$ 10.15$; Ohio, $\$ 13.82$. 
According to the census reports, in 1909 Vermont had 1,030,618 acres of hay and forage and produced 1,502,730 tons valued at \$16,333,530. These figures show that in 1909 Vermont ranked as the twenty-second state in acreage, the twentieth in production and the sixteenth in value of crop. According to the statistics published in the Government Crop Reporter, in 1912 Vermont ranked fifteenth in acreage, seventeenth in production and eleventh in value.

While Vermont's average yield falls below the average yield for the United States, its average excceds that of the great hay growing states for the period 1909-1912. The large yield in the irrigated states of the West brings up the average for the country. The total value of hay and forage crops in Vermont in 1909 was six times that of the cereals of the state, about twice that of potatoes, and represented about three-fifths of the total value of Vermont crops for that year. The hay and forage acreage in this state is nearly eight times of that of the cereal acreage. The increase in acreage from 1899 to 1909 was 2.4 per cent and the increase in value of the crop during the same period was 54.9 per cent.

Although hay is the principal Vermont crop it is possible largely to increase the yield by means of more extensive agriculture and a better system of crop rotation. Vermont can do better-much better-than she is now doing in the production of hay and an excellent opportunity is afforded in this state for a larger production of this important crop. Prof. L. R. Jones, now of the University of Wisconsin, has said of Vermont's opportunities along this line "Both the climatic and the soil conditions of this section are peculiarly suited to the growth of grass and the agricultural reputation of New England is largely based upon this fact. Nature has given a wider variety and more luxuriant growth of valuable natural grasses than in any other like area in the United States."

\section{ALFALFA IN TERMONT}

While alfalfa has not been grown extensively in Vermont-only 252 acres were reported in 1909 -it has been grown successfully in Grand Isle county, which led in the production, with Addison county a close second. An alfalfa expert has said that he has never seen alfalfa cast of the Mississippi river superior to that in the fields of Grand Isle. A Grand Isle farmer has written the Publicity Bureau as follows regarding his experience in alfalfa growing:

"I have been growing alfalfa now fifteen years, the first five years on a small scale which was not very satisfactory, as we did not cut it early enough or cure it properly. All agricultural papers said to cut it when it was well blossomed out, which we did, and cured it as we did our clover and other hay. We found that the leaves dropped off in handling and left a woody stalk that cattle did not care for. We now cut it as soon as we see a blossom and let it wilt a short time then cock it up and let it stand three or four days, then open and air it 
and put in the barn. No leaves will drop and if it is good weather when put in it will come out of the mow as green as the day it was cut. We put in about sixty-five tons last year and it averaged about five tons to the acre, and we are seeding ten acres this year. I wish my hay was all alfalfa."

\section{TOBACCO}

While tobacco is not extensively grown in Vermont, there are tobacco farms in the southern part of the state, in the Connecticut valley that are very productive. Last year, Vermont, New IIamshire, Massachusetts and Connecticut were tied for first place in pounds of tobacco per acre. Vermont's four-year arerage, 1909-1912, was ],649.7 pounds per acre. The general average for the United States was 825.5 pounds per acre.

The great tobacco growing states of the Union are Kentucky, Virginia and North Carolina, and their average yield for the past four years is as follows: Kentucky, 829.5 pounds; Virginia, 724.2 pounds; North Carolina, 638.7 pounds. Vermont's average for the forty-year period, 1870-1909, was 1,533.7 pounds, and that of the United States for the same period was 747.6 pounds.

The average Vermont price to farmers December 1st for the fouryear period, 1909-1912, was 16 cents per pound, and the arerage price for the United States was 9.9 cents per pound. The arerage price for the same period in the great tobacco growing states was as follows: Kentucky, 8.9 cents per pound; Virginia, 9.7 cents per pound; North Carolina, 11.9 cents per pound.

While Vermont's tobacco crop is not large in the aggregate, this crop record affords another excellent illustration of the fertility of Vermont soil, and it is probable that the tobacco output of the state could be considerably increased.

\section{MAPLE SUGAR}

No state in the Union is so distinctly associated with the production of high grade maple sugar as is Vermont. Probably the majority of the American people involuntarily think of Vermont when maple sugar is mentioned. Of course the Green liountain state does not produce all the maple product, but for many years it has led all states in the production of maple sugar, although other states have led in the production of maple syrup.

According to the census report, Vermont and New York produced over 77 per cent. of the total crop in 1910, over 70 per cent in 1900 , over 74 per cent. in 1890 , over 60 per cent. in 1880, and these two states, together with Pennsylvania, Ohio, New Hampshire, Maryland and Michigan, have produced over 90 per cent. of the total maple sugar crop since 1880. The money value of Vermont's production of maple sugar and syrup in 1910 was $\$ 1,086,933$, according to the last census report. 
It is certain that Vermont might increase largely the output of maple products, but owing to the high price of maple wood not a few orchards have been cut down, a process comparable to that of killing the goose that laid the golden egg. Prof. C. W. Woodbury of Norwich University estimates that two-thirds or less of the maple trees of Vermont are tapped. In order to get a more accurate idea of the maple sugar production of Vermont and its possibilities, the Vermont Legislature, during its recent session, provided that the listers when taking the annual list shall ascertain approximately how many maple trees are tapped, the number of maple trees available and not tapped and how many pounds of maple sugar and how many gallons of maple syrup were made by each person engaged in making maple sugar or syrup during the preceding year. This information is to be compiled by the Secretary of State and published in the report of the Commissioner of Agriculture.

The sugar maple is a long-lived tree. William Chapin of Middlesex has told the story of a sugar maple two hundred or two hundred twenty-five years old, a cross section of which disclosed tapping marks for a hundred years or more.

Maple sugar is made at a time of the year when other farm work is not pressing, and it is a most desirable side line adding materially to the farm income. Pure maple products are a luxury, and the market is capable of almost unlimited expansion. With a reputation firmly established, and a demand for high grade products exceeding the supply, maple sugar making on a larger scale deserves to rank among Vermont's agricultural opportunities.

\section{APPLES}

Of all the agricultural opportunities that Vermont affords, and they are many, the opportunity afforced the apple grower who will adopt modern, scientific methods must be placed in the forefront. There is no better place to-day than Vermont in all the length and breadth of the United States for the profitable raising of apples and there are few, if any, as good, all things being taken into consideration.

There are three great and compelling reasons why Vermont is the ideal section of this country for the profitable growing of high grade apples, and these reasons are: unsurpassed soil and climatic conditions; cheapness of good orchard lands; and proximity to the best markets.

Prof. M. B. Cummings of the University of Vermont states the case well when he says: "Vermont is a natural apple state and lies well within the apple belt of the United States. We have a climate which is congenial to the apple; abundant rain in most seasons, a warm summer and a winter not too severe. However, the winters are cold enough to assist in repressing insect pests and fungus diseases which are less in evidence here than elsewhere in this country. The soil is well adapted to the apple tree; generally well drained, for the 
most part easily tilled and seldom too scant in fertility. Granite and limestome soils prevail, and these are conceded to be congenial to apple roots. Grafted as well as native trees live a long time in our State. One may see nearly everywhere throughout the State the native trees which possess an almost indefinite span of life. 'These old patriots appear in out of the way places. They have lived and apparently have thrived in absolute neglect and sometimes under abusive treatment. If native, uncared-for trees will bear for fifty years, what may one expect of grafted fruit grown in cultivated orchards? The few who have tried modern methods of orcharding in Vermont are satisfied with the present environmental condition."

Not long ago Hoard's Dairyman contained an article regarding a peninsula in Wisconsin running up between Lake Michigan and Green Bay which was considered a wonderful apple growing region because it was underlaid with limestone. The article further relates an experiment performed by a Michigan apple grower who had noted the benefit which was derived from the limestone soil of this Wisconsin peninsula, and had placed a quantity of ground limestone about every apple tree in his orchard of 125 acres. When the Almighty created this portion of the world now known as Vermont he underlaid much of it with limestone rock, so that to-day Vermont is the leading marble producing region in the world. Therefore, Vermonters do not need to apply limestone to their soil, as this was done for them in the beginning, and the fact has much to do with the excellence of the Vermont apple.

The fact that Vermont is well watered adds to its desirability as an apple growing region. In the Yakima valley, Washington, in 1910, water was drawn five miles in barrels to irrigate orchards. Vermont is not compelled to depend upon irrigation.

The Vermont apples are noted for their good color, freedom from blemishes, superior flavor, crisp, juicy flesh and excellent keeping qualities. Prof. Lowell Raudenbush and others who have studied conditions say that with one or two inconsiderable exceptions no better apple ground than Vermont exists in our country.

In concluding an article on "Apples in Vermont,' recently published in the Country Gentleman, Samuel Frazer, writing of the men now going into apple growing' in this state, said: "They are prepared to utilize the forces which nature has given them-the magnificent climate, the cool fall nights which put the color on fruit. From now on we may expect that Vermont will stand out as one of the sections which will be ranked with Hood River in apple growing history."

One may purchase good apple land at almost any price he desires to pay. Probably prices are higher in Grand Isle county than in other parts of the Champlain valley and elsewhere, but even there they would seem absurdly cheap to the apple grower accustomed to 
prices of orchard land in Oregon, while upland pastures that would grow the best of apples may be purchased often for only a few dollars an acre.

\section{Nearness of Markets}

The nearness of the best markets may be ascertained by looking at any map of the United States. Within a radius of 500 miles from Montpelier, the capital of Vermont, situated near the center of the state, there is an urban population exceeding $21,000,000$ or at least half the urban population of the country, which was shown by the census of 1910 to be $42,623,303$.

The most important railroad systems of the East compete for Vermont freight and the Champlain valley has the benetit of water transportation to New York City by way of Lake Champlain, the Champlain canal and the Hudson river.

Vermont apple lands may be divided into two sections, the Champlain valley and the hill country. Possibly a third section should be added, the Connecticut valley, although many would include that in the second section mentioned. 'T. L. Kinney, a well known Vermont apple grower, says: "The Champlain ralley was the first valley in the United States which ever got a reputation as a commercial section tor growing apples." Lake Champlain influences the temperature of the region and makes it particularly good for apple growing. A well known apple grower of the Champlain valley is Arthur H. Hill of Isle La Motte and he has prepared for this volume the following article on

\section{Apple Growing in Vermont}

"It will be news to many persons inside and outside of this state to learn that apple growing in Vermont has developed to the dignity of an important commercial industry-that in certain sections, in fact, it is the distinctive feature of local enterprise. This development has been comparatively recent, so that those in closest touch with it have hardly yet felt the full significance of the change or have dared to look forward to future possibilities. Even the men most deeply engaged in commercial apple growing are still in the experimental stage of the business.

"That part of Vermont in which the commercial production of apples has received most attention is unquestionably Grand Isle county. Grand Isle is located in the extreme north west corner of Vermont, touching Canada on the rorth, and being separated from New York by Lake Champlain. It consists practically of three islands, Isle La Motte, 'North Island' and 'South Island' and one peninsula, Alburg. It is the smallest county in the state, comprising only about 50,000 acres, but has about 47,500 acres in farms according to the last census. Being practically surrounded by the waters of Lake Champlain makes it naturally a very favorable district for fruit growing. 
"Practically all of Grand Isle county is available for apple growing. Geologically the territory belong's principally to the Chazy, Trenton and Utica limestone formations, strata which themselves yield valuable agricultural soils, though the surface soil over most of the county is probably deposited from other sources.

"A very thorough investigation recently made, reaching personally to each fruit grower in Isle La Motte, shows that in the smallest town in the county there are:

No. of growers. Bearing trees. Trees too young Average yearly

$44 \quad 15,582 \quad$ to bear.
crop in barrels. 18,240

The other towns in this county are being surveyed, but it is safe to say that fully 50,000 barrels of apples are shipped out this county annually by about 200 growers.

"For planting a new orchard most Grand Isle county growers prefer two-year-old trees but a few of the more up-to-date horticulturists are using one-year old trees. First class budded trees of standard varieties, two-year-old, cost $\$ 12.50$ to $\$ 18$ per hundred. Some people pay more, but that is their privilege. First class oneyear-old trees can be had for one half the price of two-year-old trees.

Every commercial orchard in Grand Isle county is under cultivation. Young orchards are planted to corn, beans or similar crops requiring cultivation. Bearing orchards are ploughed early in the spring and harrowed throughout the season to July 1st or later and then some cover crop is sown. Buckwheat has usually proved to be the best. Most orchards in Grand Isle county are fertilized with barnyard manure, but some receive phosphoric acid and potash in addition. Spraying is now a settled practice among Grand Isle county apple growers and most of the larger successful growers have good power sprayers. Lime-sulphur and arsenate of lead are used mostly now in preference to the Bordeaux mixture and Paris green, although many fruit growers are still using Bordeaux for the first spraying.

"Apple growing as a special industry under the conditions which obtain in the region under consideration pays and pays well. One orchard of four acres containing 200 trees of Fameuse has averaged to net over $\$ 1,000$ every year for the past twenty years. Last season E. S. Fleury picked fourteen barrels of Mintosh Red from one tree, worth at least three dollars per barrel, or fifty-two dollars. These results are not extreme, but they were secured by men who take care of their orchards. Already companies are being formed to produce and market fruit on a financial basis, and the Eastern Fruit and Nut Company, capitalized at $\$ 100,000$, has acquired over 200 acres on Grand Isle and is putting out about 10,000 apple trees.

"We have the best markets in the world within 500 miles of us, and apples in car lots can be delivered in New York City in three days at twenty-five cents per barrel. Buyers from Boston, Buffalo, New 
York City, Philadelphia and Chicago are here after the apples every season, and the farmer who has good fruit to dispose of can always get a good price right here at home. Vermont apples, especially from Grand Isle county, are good keepers, well flavored, and command the highest prices in the New York market.

"With the same care and attention to details practiced by the Far Western fruit growers, we can grow better fruit here in every way at less than one-quarter the cost. There good orchard lands cost a thousand dollars per acre up. Here good orchard lands cost fifty dollar's per acre up. It cost \$600 freight to put a carload of Oregon or Washington apples into New York City. It cost us here in Vermont \$50 freight on a similar carload into New York. What I have said relative to fruit growing in Grand Isle county is applicable to every other county in the Champlain valley.

"Wherever in Vermont apples will grow wild in fence corners and in old pastures under neglect, it is possible to grow first class fruit under proper cultivation. Men like O. S. Rixford of Highgate, C. T. Holmes of Charlotte, A. T. Clark of Vergennes, G. H. Wright of Middlekury, R. L. Hemenway of Bridport-and by the way I have known Mr. Hemenway's Northern Spy apples to sell for fourteen dollars per barrel in New York-John McLane Stevens of Orwell, D. C. Hicks of North Clarendon, Ernest West of Dorest, and A. A. Halladay of Bellows Falls, grow as fine Vermont apples as can be produced and are not surpassed by any growers of fine fruit in the world."

\section{Profit in Upland Orchards}

The Champlain Valley is not the only part of Vermont, however, in which good apples may be grown profitably. H. W. Collingwood, editor of the Rural New Yorker, says: "If I were a younger man today I would willingly invest every dollar and dime I could get in hill land in New England and plant it to an apple orchard. There will be an enormous market for the fruit. These hillsides of Vermont and New Hampshire are the best places for fruit. It needs good, steep drainage. The cold air moving down and the warm air rising gives a great protection from frosts."

Prof. William Stuart, formerly of the University of Vermont, has said: "There is in Vermont today much hill-town land having a valuation of from five to ten dollars per acre which is now devoted to pasture or is largely waste land, hardly yielding sufficient revenue to pay the taxes, which if devoted to apple orcharding might be made to return an average income of from fifty to one hundred fifty dollars per acre, or even more. From having a valuation of from five to ten dollars per acre it might have one of five hundred dollars or more if it was covered with thrifty, well-cared-for apple trees. *** There is no reason why hill-town orcharding may not be suceessfully and profitably practiced in Vermont."

G. H. Terrill has declared concerning Vermont apples that "the higher up on our hillsides, the better the keeping qualities. I believe 
there is nothing we can plant these high hills to that will produce better returns than the good red apple."

\section{An Oregon Opinion of Vermont}

An Oregon fruit grower, writing in the New England Farmer, said: "We have no hesitancy in saying that better flavored fruit can be produced in sections with winters like those in Vermont than in sections like Oregon and Washington, where the winters are miid. The cold acts upon the tree as it does upon the human system, tending to invigorate the tree in every way and destroying the fungi and larvæ which are injurious to the tree. It is a fact, though generally unknown in the East, that more fungi and insect pests are found in the orchards on the Pacific Coast than in the East.

"There are many advertising pamphlets circulating in the East picturing wonderful opportunities in the West, but if as much pains were taken to study and advertise the resources of the East they would present opportunities equal to those in the West.

"Good bearing orchards range in price from $\$ 1,000$ to $\$ 3,000$ per acre in Washington and Oregon, but this price does not include buildings. Irrigation is a necessary and expensive problem to be considered. What in the West would buy only one or two acres would purchase in the East an average size farm with buildings where irrigation is unnecessary. We firmly believe that an acre in the East can be made to clear as great a profit as an acre in the West by applying Western principles to fruit growing.

"It is the Easterners that are making Oregon what it is. Why do they not put forth this effort to develop their native States where everything is in favor of fruit culture? With climate and soil adapted to fruit raising, varieties like Rhode Island Greenings, Baldwins and Northern Spies, large markets close at hand and extreme low price of land, the East offers an exceptional field for scientific fruit culture."

\section{Favorable Tax Legislation}

The last Legislature passed a law exempting orchard trees from taxation for fifteen years from the time of planting, so that land devoted to orchard purposes shall be taxed for the period mentioned at the same rate assessed before the trees were set out.

In 1909 Vermont ranked twenty-fifth among the apple producing states, the reported yield for the year $1,459,689$ bushels. While Vermont has not entered largely into the competition at apple shows, vet at the New England Fruit Show held at Boston in 1911, out of five premiums for Northern Spies, Vermont took three, the first, third and fifth, and a Grand Isle county man took the blue ribbon. Vermont growers took the blue ribbons for McIntosh Reds and Spitzenbergs, the second prize for Rhode Island Greenings in boxes, the second prize for Northern Spies in boxes, and the third prize for Northern 
Spies in barrels. With only seventy-six plates entered, Vermont took eighteen ribbons.

\section{Successful Apple Growers}

Probably the best known orchard in Vermont is that of C. T. Holmes of Charlotte in the Champlain Valley. This orchard, consisting of 105 acres, mostly set to Rhode Island Greenings in 1870, was in the sod for many years and bore little fruit. In the winter of 1907 , fifty acres of the orchard were given a good mulch of barnyard manure. Great benefit was experienced as the result of the mulch and cultivation. That fall Mr. Holmes picked 2,500 barrels of apples from the fifty acres cultivated and 600 barrels from the fifty acres uncultivated. Modern methods have since been pursued in this orchard. In 1908 about $\$ 7,000$ was cleared from the orchard and in 1909 about $\$ 12,000$. In 1910 the crop sold for $\$ 20,000$, of which sum about $\$ 15,000$ was profit. The Greenings from the Holmes orchards have sold at prices ranging from five to seven dollars per barrel.

R. L. Hemenway of Bridport, in the southern part of the Champlain Valley, has an orchard of thirty acres, planted between the years 1870 and 1872, which is one of the best in Vermont. Some of his best Northern Spy apples have sold in the New York markets as high as fourteen dollars a barrel. In 1910 his third grade Northern Spies sold for $\$ 5.60$ and $\$ 6$ a barrel, his fancy grade from $\$ 6$ to $\$ 9$ a barrel, and his extra fancy grade from $\$ 9.50$ to $\$ 14$ a barrel. His Greenings sold that year at prices ranging from $\$ 5.50$ to $\$ 6.50$ a barrel.

From H. B. Allen's orchard in South Hero, in 1899, which was an "off-year," so-called, the net income was $\$ 1,400$ from fourteen acres. The apples from this orchard sold in the New York markets at an average price of $\$ 5.22$ per barrel. Some of the best brought $\$ 8$, $\$ 9$ and $\$ 10$ per barrel. In 1910 W. N. Phelps of South Hero sold 4,000 barrels of apples at an average price of $\$ 3$ per barrel. In $1.911 \mathrm{~F}$. A. Drew of South Burlington picked 1,000 barrels of apples from 550 , trees and received $\$ 4.75$ per barrel at Burlington.

Dr. H. C. Tinkham, Dean of the Medical Department of the University of Vermont, and G. L. Pease have converted a small farm of 14 acres just south of Burlington into a profitable investment. An old orchard has been renovated, the trees trimmed, the cavities filled with cement, the soil fertilized and cultivated, and the owners have sold in a single season $\$ 2,000$ worth of apples, also tons of winter squash raised on the same land. $O$. S. Rixford of Highgate has a Fameuse orchard of 50 acres, set out in 1885 on the northern slope of a stony mountain pasture, which produced 10,000 bushels of fine fruit in 1906.

These are illustrations gathered at random with no attempt to make a thorough canvass of the state. 


\section{No Danger of Over-Production}

But somebody will ask: "Is there not danger of orer-dloing the apple business?" In answer to this question it is proper to say that the census figures show that in the period, 1899 to 1909, the apple production of this country decreased from 175,397,600 bushels in 1899 to $147,522,318$ bushels in 1909, or a falling off of $27,875,282$ bushels during the decade mentioned. During the same decade it was shown that apple trees of bearing age had decreased from 201,794,000 in 1900 to $151,323,000$ in 1910 , a loss of $50,471,000$ trees. During that period the population of this country increased from $75,994,575$ in 1900 to $91,972,266$ in 1910, or $^{\circ}$ a gain of $15,947,691$. Taking into account the decrease in apples and apple trees, the increase in population, the rise of the important apple canning industry during the past few rears, and the possibility with a better system of distribution of food products of vastly increasing the market for fruit, it will be seen that there is no occasion for worry over a glut in the apple market for a considerable period of time.

There are a good many apple orchards in Vermont that may be renovated and made profitable in a comparatively short time. Why go to the Pacific Coast, pay enormous prices for apple lands and be compelled to ship fruit 3,000 miles across the continent, when just as good land can be bought in Vermont at from one-fiftieth to one-twentieth the price, with the best markets of the world at our very doors? The same care in cultivating, spraying, picking and packing used in Oregon will bring just as good results in Vermont, and the advantages of the Vermont producer over his Western rival are too obrious to require any extended argument. Any person desiring to engage in apple growing will serve his own best interests by investigating conditions and opportunities in Termont before he invests elsewhere.

Any person considering the purchase of land here for the purpose mentioned should obtain or consult a copy of a very valuable bulletin on "Vermont an Apple Growing State," issued in October, 1911, by the Vermont Department of Agriculture. It gives the rarieties of apples best adapted to the various sections of the state and contains much information absolutely essential to an intelligent understanding of conditions in Vermont.

\section{SMALL FRUITS AND VEGETABLES}

II. A. Jenkins of Bradford, Vt., one of the largest strawberry growers in New England, uses ten acres for raising this fruit, half of this area being used for bearing plants and half for new "sets," which will come into bearing the following year. During the season of $1911 \mathrm{Mr}$. Jenkins shipped at the rate of 100 bushels per day and as many as 121 bushels per day. He employs as many as forty pickers, who camp ont during the season of three or four weeks. The Vermont strawberry season follows immediately after the Massachusetts season, and good prices are secured. 
In 1911, L. S. Richardson of Chester Depot, picked and sold from the rear end of a village lot, one-fourth of an acre in size, $\$ 200$ worth of strawberries. Another man realized $\$ 275$ from a half acre of strawberries, and a Hyde Park man made $\$ 900$ from two and a half acres of land set out to strawberries.

In 1908, E. H. Hallett, of St. Johnsbury, raised 500 bushels of strawberries, or 16,000 quarts, on one acre of land. There are other large growers of strawberries in Bradford besides Mr. Jenkins and strawberries are grown in considerable quantities in St. Albans and elsewhere.

Vegetables are raised both for the local markets and for canning factories. One St. Albans farmer raises every year about 3,500 bushels of string beans for canning. In 1911 a St. Albans farmer raised about 125 tons of sweet corn, for which he received $\$ 10$ per ton at the canning factory.

The following letter, written to the Publicity Bureau by L. H. Sheldon of Fair Haven, shows how this enterprising dealer markets his fruits and vegetables: "Our plan of operation is to develop the local market. Our summer hotels at present use large quantities of canned goods, partly I think, because they are easily prepared, but it would seem to be our business to have the stuff ready for them, advertise freely so as to let their guests know that they can have fresh vegetables if they choose, and their patrons will do the rest.

"We are surprised at the small amount of trade that can be secured in a country town. We try to get close to the consumer, therefore retail most of our produce, running a sales-wagon every week in the year. We run this wagon once or twice a week during the winter, twice or three times a week during the spring and daily during the summer. We also run a wagon daily for three months to the summer resorts at Lake Bomoseen, alternating each side of the lake, so we reach customers every other day. We try to raise everything we can on the farm, but at certain seasons piece out with Southern stuff, although it is not comparable to our home grown fruit and vegetables.

"It is strange that our state does not grow more small fruits, raspberries, gooseberries, currants, etc. Our strawberries always sell at 15 cents, raspberries 18 to 20 cents, and I think that there is no section of the country more sure to produce good crops. Crates can be had for nothing, or for a mere trifle, compared with what the Southern producers have to pay, and when we realize what a low price the fruit must net them, it would seem that we are neglecting our opportunities not to supply fully our home market. When I think how the high cost of meat, together with more cultivated tastes, is turning the people to the fruits and vegetables of the farm, I grow enthusiastic over the possiblities of the home market.

"We do not propose to hide our light under a bushel. Every other husiness advertises, why not the farmer? We try to keep people thinking about Valley Farm in connection with good things to eat. 
We take space by the year in our local paper, and print sometimes a list of what we have to sell, sometimes a little fun, anything to make people read our ads., and we know they do read them.

"To sum up, we try to have a large variety of fruits and vegetables. We try to develop and increase the local market, to get a reputation for a square deal, and to let people know what we are doing. We are hoping in the near future to own an auto truck. We can see great possibilities in it for our business."

Pears, plums and cherries grow well in Vermont and the quality produced is excellent. At a recent State Fair, G. H. Wright \& Sons of Middlebury displayed thirty-four varieties of grapes.

Maple Ridge Fruit Farm of Dummerston has exhibited remarkably fine peaches from a peach orchard of 1,500 trees. There is an excellent opportunity for fruit growing in Vermont. It is difficult to get raspberries, even for the home market, and there would seem to be an opportunity for growing such berries here at a good profit.

Vermont has made an excellent record in the growing of strawherries. L. H. Sheldon, of Fair Haven, Vt., a successful market gardener, says: "The strawberry grows to perfection in our state (Vermont). The long winter rest seems to be just what it needs and we do not suffer from frost oftener than in the South. In twenty years I have never grown a crop that I thought did not pay expenses; on the other hand, the best record is at the rate of over 1,000 quarts per acre. Compare our prices with what the Southern growers get. Very many Southern berries were sold in our town last season for 12 cents per box. The shipper must furnish crates and boxes, pay express to New York, then to Albany, thence to Fair Haven, pay one-perhaps two-jobbers' and one retailer's profits, to say nothing of the thousands of crates of damaged fruit being dumped in New York harbor, and the consumer at the end usually gets a basket about two-thirds full of nearly green or rotten fruit. We can grow more and finer berries per acre, cut out all those expenses, for we get the Southern man's crates for little or nothing, boxes are often returned, and our price is generally higher; and yet I know farmer boys working today in factories or mills for a pittance above their board, girls who have spent years in fitting themselves to teach in school thirty-two weeks in the year at $\$ 7.00$ per week and board themselves, when they could hire the hard work done in the strawberries, and sell at wholesale, and in picking and packing they would excel.

\section{HORSES}

For the better part of a century Vermont has been famous as the land of good horses. It was John G. Saxe, the poet, who said:

"Vermont is famous for four things:

"Men, women, maple sugar and horses; The first are strong, the latter fleet, The second and third exceedingly sweet, And all are uncommonly hard to beat." 
As the home of Justin Morgan, founder of the famous Morgan strain, Vermont has ranked high in the breeding of horses. From 1850 to 1860 Vermont raised and sold more horses than any other state in the Union. For a time the raising of Morgans was neglected, but the development of this wonderful breed has been revived and again Vermont has the opportunity to increase its prosperity by raising a larger number of high grade Morgan horses.

The horse, Justin Morgan, was owned by a man of that name who emigrated from West Springfield, Mass., to Randolph, Vt., about the time of the birth of the animal, in 1789. The Morgan Horse Register says the horse was sired by True Briton, said to have been captured from Col. James DeLancey, a British officer, during the American Revolution. By many it is suprosed that Justin Morgan descended from Arabian stock. When a colt he was brought to Randolph by Mr. Morgan. He was used by him as a breeding animal and several years later was sold, being owned in St. Johnsbury, Montpelier, and elsewhere.

The horse Justin Morgan was about fourteen hands high, weighed about 950 pounds, and was a dark bay with black full mane and tail. Solomon Steele of Derby Line, Vt., who knew the horse well, said: "No man of ordinary judgment could fail to discover his peculiar" points of excellence, his oblique shoulders, high crest, fine ear, prominent and sagacious eye, perfect head, large and expanded nostrils, strong loins, long hip, deep and well spread chest, high withers, short pasterns, strong and sinewy limbs, with all the important muscles far surpassing in size those of any other horse of his weight ever seen in America." It was also said of Justin Morgan that he could "outwalk, out-trot, out-run, out-pull," every horse entered against him.

Six of the best known sons of Justin Morgan were the Fenton Horse, the Hawkins Horse, Sherman Morgan, Bulrush Morgan, Woodbury Morgan and Revenge. Black Hawk was a son of Sherman Morgan and Ethan Allen was a son of Black Hawk. Green Mountain IIorgan was a son of Gifford Morgan, and he a son of Woodbury Morgan.

Green Mountain Morgan probably was one of the most beautiful horses ever reared in the United States. It was said of him by one who knew him well: "When moving I never saw such majesty embodied in horse flesh as was displayed by Green Mountain Morgan. His arched neck seemed clothed with thunder and his floating mane and tail, his eye of fire, his red distended nostrils, revealed more perfectly to my mind the original of those fiery, magnificent coursers, the Greek ideal of the war horse, to be found in the Elgin marbles, than I ever saw elsewhere." Green Mountain Morgan was called by General Wool of Mexican war fame, "the finest parade horse in the country.' In 1860, Governor Banks of Massachusetts, seeking the finest possible mount for a muster at Concord, sent to Williamstown. 
Vt., and secured Green Mountain Morgan for the oceasion. Although the horse was then twenty-five years old, he showed no signs of age, played his part to perfection, and was "the observed of all observers."

While the Morgans have not, as a rule, been noted as trotting horses, some of the speediest of American racers have had Morgan blood in their veins. Such a list would include Dan Patch, Lou Dillon, Uhlan, Dariel, Audubon Boy, Major Delmar, Sweet Marie and The Harvester. One of the most famous of American races was held June 21, 1867, when forty thousand people saw Dan Mace drive the famous Mlorgan, Ethan Allen, with a running mate, in a matched race with the great Dexter, winning the race. It has been said that probably no horse race in the country ever has excited more enthusiasm than this.

Vermont has carried off the honor's at several of the great world's fairs. Knox Morgan, owned by F. G. Chandler \& Son of Peacham, won the first and championship prizes at the St. Louis Exposition. The first $\$ 1000$ premium for all harnessed stallions in the United States, the second of $\$ 350$ and the third of $\$ 150$, offered at the St. Louis, Mo., fair in 1858, were awarded to three sons of Vermont Black Hawk. Fiftyseven stallions were exhibited and every well known breed of horses in the country was represented.

Gen. Sheridan's "Rienzi," which he rode to Cedar Creek from "Winchester twenty miles away," was a Morgan horse, and Gen. Custer's favorite horse was a Morgan. When one of the sculptors engaged to model the statuary for the Chicago World's Fair made a great model in clay of a typical specimen of the American horse, Vermont furnished a Morgan, a daughter of Daniel Lambert, for the model. It was fitting that one of the pieces of the silver service presented to the battleship Vermont should be embellished with the head of a Morgan horse.

The Morgans have been famous for their endurance. Many stories are told of the remarkable feats of strength of Justin Morgan and some of his descendants. In 1853 the New York Herald, in an article on the Sixth Avenue Railroad, said: "Four-fifths of all the horses employed on the road are from Vermont and New Hampshire and of these nearly all are of the celebrated Morgan breed."'

Justin Morgan has been called the mosi remarkable animal in the world from the standpoint of prepotency. It is proper to quote a few of the many opinions expressed regarding this wonderful animal. In an article dealing with horses in Vermont, one of the editors of Louisville, Ky., Journal, who had made a tour of the Northern states in 1845, said: "There is no doubt whaterer of this-that the breed of the MIorgan horse was and is now in the few instances where it can be found, far the best breed of horses for general use that ever was in the United States-probably the best in the world; and it is remarkable that the breed was and is now known by many and striking perculiarities common to nearly every individual.", 
The American Farmer's Encyclopedia, published in Philadelphia, said in 1844: "Perhaps the very finest brced of horses in the United States when general usefulness is taken into consideration, is what is commonly known in the Northern and Eastern states as the Morgan horse."

The American Horse Breeder has said: "Probably no other family of horses ever existed in which so large a proportion of its members 'acted well their part' with greater honor to themselves and their family than that founded by the noted stallion, Justin Morgan. The majority of these were remarkably cheerful, docile and faithful in whatever station they were placed. Their great strength in proportion to their size was proverbial, and their endurance was wonderful. No horses of their size could compete with the old time Morgans. either for pulling logs in the clearing, loads on the road in a team, on the plow, the family carriage or under saddle on parade. There never has been a family that transmitted its valuable qualities with greater uniformity than the Morgan."

A correspondent of the Indiana Farmer said: "If there is any animal which is a friend to a farmer, it is the Morgan horse, which, not so long ago, made good from drawing the entire family to church on Sunday, to hauling the big loads of hay from the meadows on a week day."

"There never was a better all-round horse on American soil than the Morgan, and liverymen everywhere bear testimony as to its value," says the Kansas Farmer.

David Buffum, writing in Outing on "Making Carriage Horses in America," said of the Morgan: "This family has gone on record as the gamest, the most beautiful, and all things considered, the nearest to perfection of any that America has produced. Though not as fast at the trot as some other families, they were all fast; they all showed uncommon endurance and stamina; they had the points of equine excellence and elegance that distinguished the Arab; and they bore themselves as superbly as the proudest of the aristocratic sons of the desert."

President Benjamin Harrison attended a meeting of the Vermont Association of Road and Trotting Horse Beeders at White River Junction in 1891, and said: "I understand that it was so arranged that after I had seen the flower of manhood and womanhood of Vermont, I should be given an exhibition of the next grade of intelligence and worth in the State-your good horses. I had recently through the intervention of my Secretary of War (Hon. Redfield Proctor), the privilege of coming into the possession of a pair of Vermont horses. They are all I could wish for, and, as I said the other day at the little village from which they came, they are of good Morgan stock, of which some one has said that their great characteristic is that they enter into consultation with the driver whenever there is any difficulty." 
W. II. H. Murray, who has written so charmingly of out-of-door life, has said: "The reproducing capacity of this horse (Justin Morgan) considering the treatment he received, was simply marvelous. Unappreciated and abused half his life, it was the merest accident that his value as a stock horse was discovered at all; and even then he was bred indiscriminately to mares, unassisted by the least intelligence in the matter. Still, in spite of all obstacles which neglect and ignorance imposed, the reproductive faculty was so superlatively strong that he founded a family true to the original type and more able to protect itself from infringement of foreign blood than any family of horses, perhaps, that the world has seen.'

When the racing craze arose in this country the breeding of Morgans was neglected and for a long period little attention was paid to this distinguished Vermont family. A few years ago, however Senator Proctor, of Vermont, long chairman of the Senate Committee on Agriculture, succeeded in interesting the Department of Agriculture in the revival of the Morgan type. Col. Joseph Battell, of Middlebury, Vt., gave to the United States 435 acres in the neighboring town of Weybridge as a breeding farm. There are now about seventy Morgan liorses on this farm, including eight or ten of the finest Morgan stallions to be found, headed by the famous sire, General Gates.

G. H. Rommell chief of the Bureau of Animal Husbandry, says : "If we can get the Morgan back we will have reproduced a breed of horses that is without exception the best that the United States has ever seen-it is possibly one of the greatest breeds of horses that the world has ever seen. The Morgan horse, bred true to type, had qualities that made him valuable on the farm or as a carriage horse, and that made him salable,****If we can produce a Morgan horse that will be profitable on Vermont farms, to Vermont farmers, we will by so doing bring to Vermont what has krought to the state more fame than any other one thing-her great men alone excepted."

In order to give the farmers of Vermont a larger opportunity to breed from Morgan stallions than they would have if only the Morgan breeding farm at Weybridge were accessible, the government has directed that good Morgan stallions be located at Northfield, Plainfield, West Fairlee, and Hartland Four Corners, in. Termont. Farmers must furnish sound mares of a square trotting gait and if they will give the Government an option on the eolt at $\$ 150$ when three years old the service of the stallion is free. If the government does not wish to take the colt no charge will be made for the service. If the farmer thinks the colt is worth more than $\$ 150$ then he must pay a service fee of $\$ 25$ for mature stallions and a smaller fee for younger horses.

This affords an excellent opportunity to raise good horses at a profit. The problem of securing remounts for the United States Cavalry regiments is a difficult one, and a good market is assured. Mr. Rommell, already quoted, has said that the Vermont and Maine cav- 
alry were by far the best mounted of any in the Union Army during the Civil War, and these regiments were mounted as a rule on Morgan horses.

The Morgan Horse Club is an active organization which meets annually at the time the Vermont State Fair is held and some notable exhibits of Morgan horses-the best to be seen in the country-are shown on these occasions. Last year there were 188 entries.

The breeding of Morgan horses is one of Vermont's opportunities. The reputation of these horses is already established, there is a good market for them, and with the aid afforded by the United States government this is an opportune time to enter upon such breeding.

The raising of other breeds of horses will be found profitable in Vermont-large draft horses, for example. It is estimated by a competent authority that Vermont farmers are sending $\$ 500,000$ yearly out of the state for the purchase of Western draft horses. It ought to be profitable to raise such horses here, not only to supply the home market, but the markets of other States.

\section{SHEFP}

For nearly a century Vermont has been famous for high grade Merino sheep. To the states of the West and South, to Argentina, to Australia and to South Africa, have gone Vermont sheep to improve the quality of the breeds in those states and countries.

An agricultural bulletin on sheep raising prepared by Kenneth A. Atwood, says: "Few states are better adapted to this industry than is Vermont. Her soil, climate, topography, natural grasses, and the skill attained by her breeders, have produced Nerinos never surpassed and seldom equaled by those of any other state or country."

It is known that Merino sheep were brought into Vermont previous to 1808. A Mr. Stoddard of Rupert, owned a flock of Merinos before that date. In 1808 Colonel Humphrey placed two valuable imported rams on a farm in Hartland.

Hon. William Jarvis, who had been United States Consul at Lisbon, Portugal and charge d' affaires, imported a flock of 400 Spanish Merinos, bringing them to Claremont, N. H., and in 1811 he transferred them to a farm he had purchased at Weathersfield, Vt., in that fertile region of the Connecticut valiey known as "Weatherfield Bow." At different times he is said to have imported as many as 3500 Merinos. Spain was obliged to sell her world famous flocks of sheep which she had been improving for a thousand years in order to pay the cost of war, and Mr. Jarvis took advantage of the opportunity. Other smaller flocks were imported to Addison county towns. Some of the Atwood Merinos, bred by Stephen Atwood of Connecticut, were brought into Vermont. Edwin Hammond of Middlebury, breeding from Atwood Merino stock, made notable improvements in the breed, including great gains in the length and 
fineness of the wool. It has been said "that he converted the thin, light-boned, imperfectly eovered sheep into models of compactness, eovered with valuable wool."

\section{Prices and Prizes}

Nowhere else did the Merinos attain such a degree of excellence as in Vermont. An indication of the standing of the Vermont Merinos is furnished by records of prices and prizes received. The two original Humphrey rams were valued at $\$ 1000$ and $\$ 950$, respectively. In 1833 A. L. Brigham paid $\$ 232$ per head for a floek of 261 Spanish Merinos. California, a ram bred by Mr. Hammond, sold for $\$ 10,000$. Gold Drop, from the same flock, was valued at $\$ 25,000$ and offers of $\$ 10,000$ were refused. The ram Comet at three years old had brought his owner $\$ 3,000$ in service fees, while another ram at his death was reported as having earned $\$ 20,000$ for his owner. Twelve sheep, taken by George Campbell of Westminister to the exposition at Hamburg, Germany, sold for $\$ 5,000$. For many years Australian breeders paid $\$ 500$ and upward per head for Vermont sheep. In $1862-63$ prices for rams ranged from $\$ 100$ to $\$ 2,000$.

Twelve Vermont Merinos, bred by $\mathrm{Mr}$ Campbell, took two first prizes and one second prize at the International Exposition at Hamburg. At the Philadelphia Centennial Exposition in 1876 Vermont took five first and four second prizes out of a total thirteen firsts and fifteen seconds. The sweepstakes for the best ram of any age was won by Bismarek, owned by $\mathrm{H}$. C. Burwell of Bridport. The $\$ 100$ prize for the best flock went to Joseph Stickney of Shoreham. Bismarek produced in one year a fleece weighing $35 \mathrm{lbs} .93 / 4$ oz. A Promfret ram yielded $371 / 2$ lbs. What is said to have been the heaviest fleece ever secured at a Vermont sheep shearing contest, weighed $44 \mathrm{lbs} .3 \mathrm{oz}$. The proportion of the wool clipped to the total weight of the sheep was increased from 6 per cent in 1812 to an average of 22 per cent in 1880, and in some cases the average has been as high as 36 per cent.

Nearly 7,000 Merinos were shipped from Middlebury during a period of four years, exclusive of large numbers sent in small lots by express.

One who has studied the conditions in Vermont says: "The increasing popularity of lamb and mutton as meats spell success for the Vermont breeders of the mutton type. 'The nearness to market and high quality of the product should enable Vermont to compete sucessfully with range fed mutton, even though the gain in weight is secured more economically. Choice breeding animals of the mutton type are also good property. Many kreeders are now successfully eatering to this demand and there is plenty of room for more to engage in this pursuit.******Many well clad but rugged pastures are so located as to be ill fitted for dairying while they will support sheep to good advantage." 
At the annual meeting of the Vermont Dairymen's Association, held in Burlington January 5 and 6, 1910, C. C. Jones of Bennington, manager of the Fillmore Farms, who lost his life later on the ill fated steamship Titanic, had this to say concerning opportunities for sheep raising in Vermont: "Vermont was the state in all the United States at one time in which to find wool sheep. When I was in Texas we came all the way to Vermont to buy our stud stock, and we got good ones. Why? because they were raised in Vermont. We have in this state the facilitses for producing the best

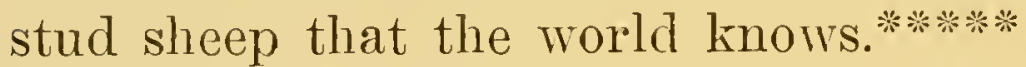

"There is a grade of sheep that we can handle here more profitably than in any other section of the United States, and that is the so-called 'hot house lamb' which is not a liot house lamb at all. It is a fall lamb and there in no place in the country where that lamb can be produced cheaper or any better than right here in Vermont. In New York city the demand every year is beyond the supply and the man who cannot raise a lamb in from nine to twelve weeks and sell him profitably for $\$ 10$ has something wrong with him. The trouble is not with the sheep. I commenced to ship to New York markets last year the 21st of December and continued until the 10th of February. The least that I got for a lamb was $\$ 10.20$ net. These lambs were not sold to private customers, but were sold to a commission man through open market, just where any one of you could sell them, and they were raised just as any one of you could raise them."

The Fillmore Farms comprise about 4000 acres, mostly in Bennington, and a specialty is the raising of Horned Dorset sheep.

It is a well known fact that sheep are beneficial to worn out pastures, and it is stated that sheep will eat 90 per cent of all troublesome weeds. Certainly Vermont offers good opportumities for profitable sheep raising.

\section{SWINE}

The census of 1910 showed that at the time the enumeration was taken there were 94,821 swine in Vermont valued at $\$ 974,779$ or almost a million dollars. An excellent market is offered and a good profit can be made in raising pork products. In only two states did the price exceed that in Vermont. It is possible largely to increase the number of swine raised, particularly if the milk is not shipped away so that none of the dairy product is available for feeding purposes.

\section{POUL'TRY}

Poultry on Vermont farms numbered a little less than one million birds in the census of $1910,938,524$, to be exact, having increased from 843,163 , reported in 1900 . The value of Vermont poultry was appraised at $\$ 607,787$, compared with $\$ 421,195$, ten years earlier. The eggs produced in 1909, as reported in the census figures, amounted to $7,037,082$ dozens, valued at $\$ 1,715,221$. 
M. A. Jull, manager and lecturer for the poultry department of MacDonald College, Quebee, has said: "The system of mixed farming as carried on in the State (Vermont) is ideal for the rearing of poultry.*** Vermont is so well adapted for poultry raising that it should be producing poultry products in large quantities for the markets which are so near. Vermont is splendidly located in respect to markets. Her home markets are good and she also has large markets near at hand. New York city is about 250 miles by railroad from the central portion of the state and if the right classes of goods are produced and shipped to New York the best prices will be received. There are other large markets, all of which are within easy reach of the more important centers of the state. The fact that there are so many large markets near the poultry producers of the state is a very important asset, since eggs and poultry products ean be shipped to these markets and sold the following day, while perfectly fresh, and freshness is one of the chief factors controlling the price.

"Vermont is so well adapted for turkey raising that it is surprising that so few turkeys are raised. Another surprising feature of the poultry industry of the state, is that there are so few ducks raised. In many places where the markets are right and transportation facilities are good, as much, if not more money can be made with ducks as with chickens.

"The poultry industry is more independent of climaie than other branches of agriculture. The climate of the state as a whole is quite favorable. The country is naturally hilly and broken and many of the valleys provide excellent shelter for poultry plants."

The demand in the great cities for strictly fresh eggs is so much greater than the supply that a great opportunity is offered. Vermont, so near these markets, should be able to supply this demand, in part, at least.

This year for the first time the boys and girls of Windsor eounty, Vermont, are being organized into poultry clubs, under the auspices of the County Y. M. C. A. organization. The first prize in the contest No. 1 will be given to the member hatching the largest number of eggs, and another to the one having the largest number of chieks still living at the end of four months, out of a setting of 15 eggs. The second prize goes to the member having the largest total weight of chickens out of 15 eggs four months after hatching; third to the member writing the best composition on hatching and rearing chickens. There are also speeial badge awards.

On contest No. 2, first prize goes to the member rearing the highest scoring bird shown at an exhibition to be arranged for in the fall; seeond, prizes for the best of the various varieties will be offered; third to go to the member with the highest egg record from pullets raised up to January 1 ; fifth, to the member presenting the best article on winter egg production; sixth, to the member showing largest 
profit in proportion to cost of raising the chickens from 15 eggs up to January 1, 1914. Specials badges will also be given in this contest.

\section{BEE-KEEPING}

Vermont leads New England in the number of colonies of bees reported by the census of 1910 .

H. W. Beecher writes of "Bee-keeping in Vermont": "Many culturists explain that conditions here are the best in the country. Certainly if proper methods are employed, excellent results may be obtained. Vermont has been fortunate in not being devastated by bee diseases that have been so prevalent in other states."

The total average yield of 38 bee-keepers reporting to Mr. Beecher was 37.44 pounds of honey per colony. Mir. Beecher says: "Considering that this report was received in 1909, when the honey production was very low, Vermont bee-keeper's are to be congratulated on these results, for it is a relatively high average. This simply proves the statement that the conditions here are of the very best for this product."

The average yield of honey in Vermont is from 35 to 40 pounds per colony. One bee-keeper reports the average yield of 44.6 pounds of comb honey for a period of 18 years, the price being from 15 to 20 cents per pound. A Fair Haven man reported 160 pounds from a single colony. Addison county produces nearly as much honey as all the other Vermont counties combined. This county alone produced 125,000 pounds of honey in 1910 . J. E. Crane of Middlebury is not only the leading bee-keeper of Addison county, but also of Vermont, and perhaps of New England. In 1909 Mr. Crane had 635 colonies and reported a yield of 42,000 pounds of honey in a single season. He ships his product to New England cities, Chicago and London. In 1909 eleven other Addison county bee-keepers each had 100 or more colonies of bees.

In addition to the direct profit of bees, they are of great valus, in pollenating crops and are particularly beneficial to apple growers. The state has provided an apiary inspector to aid in keeping bee diseases out of Vermont.

\section{FORESTRY}

In a state like Vermont, which contains large areas of mountain land, forestry products may be considered properly as one of the most important crops. Lumbering is one of the leading Vermont industries, and the opportunities for the successful growing of timber are many. Large quantities of timber are required for wood working industries, and these industries may be largely increased. There are few states better adapted than Vermont to profitable forest growing. State forests have been established as follows: Downer State Forest, Sharon, 300 acres; L. R. Jones State Forest, Plainfield, 600 acres; Hapgood State Forest, Peru, 850 acres; Battell State 
Forest, Duxbury and Huntington, 1000 acres; Lyndon Sand Forest Plantation, Lyndon, 75 acres; George Aitken State Forest, Mendon, 850 acres; West River State Forest, Townshend, 700 acres. The Hapgood State Forest is also called Bromley Mountain Park, and Battell State Forest, including the summit of Camels IIump, one of the highest peaks of the Green Mountains, is also called Camels Hump Park.

A state forest nursery has been established at Burlington, which sold 530,400 seedlings and transplants in 1912 to be used in various parts of the State. A Summer School of Forestry and Horticulture has been held at the Downer State Forest in Sharon. Fire wardens are appointed and a system of lookouts is maintained to guard against the spread of forest fires.

The Legislature of 1912 passed a law relating to the taxation of young timber which is regarded as an encouragement to the planting of forests, Vermont being the third state of the Union to pass legislation of this nature. This law provides that the lands specially classified under this act may include cut-over or other land fully stocked with forest trees not more than 15 years old, except scattered trees, the presence of which does not increase the assessed value of the property; cut-over or other land incompletely or partially stocked with forest trees not more than 15 years old, when planted with a sufficient number of additional trees to assure a spacing of approximately $6 \times 6$ feet over the entire area; and open land planted with forest trees not less than 1000 to the acre, provided that they are species approved by the State Forester, and provided further that the land is outside the limits of cities and villages. Such lands must be examined and approved by the State Forester to benefit by this tax law. Lands so classified are to be taxed at the local rate on a valuation of the lands alone, valuation to be established by the listers, but in no case to exceed $\$ 3.00$ per acre, said valuation to be maintained until 1950, when the land shall be revalued, the valuation to be established for a further period of 50 years.

Whenever a commercial eutting is mads a tax of 10 per cent shall be levied on the gross stumpage value of the amount cut. This does not apply to material used and not to be sold.

Another law was passed at the last session of the Legislature applying to forest growth over fifteen years of age, which supplements the law first mentioned. Such growth may be specially classified under this law and when so classified it shall be taxed according to the last preceding quadrennial appraisal and no raise shall be made until 1950, when it may be revalued. This law does not take effect until January 1, 1915, allowing a quadrennial appraisal to intervene. An additional tax of 1-10 of 1 per cent per annum for the period the land has been classified is levied on the gross stumpage value of timber cut. If land has been classified 20 years, and 100,000 feet of lumber has been cut worth $\$ 6$. stumpage the additional tax would be $\$ 12$. 
It is evident that under wiser forestry regulations Vermont forests may become a much greater source of permanent revenue than heretofore.

Several years ago the International Paper Company established a nursery at Randolph for raising seedlings to be planted on their lands in Vermont and New Hampshire. This company estimates that it owns about 10,000 acres of open land available for planting and that about 100 acres a year will be cut and require planting. It intends to plant this open land during the next ten years, thus planting about 1100 acres per year and requiring about 1,320,000 trees annually. It is worthy of note that this company is cutting in such a way as to have its forest growth reproduced naturally and is having all trees for lumbering marked under the direction of the State Forester.

The Vermont Sanatorium at Pittsford has been practicing forestry on lands owned by that institution. In Barnet a forest of about 15 acres, only 45 years from growing a crop of oats, is now covered with white pine, the largest 18 inches in diameter, easily worth $\$ 500$ per acre, all grown on land considered too poor to keep in eultivation. On the Billings estate at Woodstock are pines planted 28 years ago, now two feet in diameter, and Norway spruce worth $\$ 3,000$ per acre.

\section{AGRICULTURAL EDUCATION}

Vermont has entered upon a policy of agricultural education that cannot fail to be of great benefit to the state. In addition to an excellent State Agricultural College and Experiment Station at Burlington, a State School of Agriculture has been established at Randolph Center. The last Legislature gave to the Governor and an Educational Commission power to establish another school of like nature in Addison or Rutland counties.

An excellent agricultural school has been established in the town of Lyndon by T. N. Vail, one of America's leading business men.

The principal of the Vermont State School of Agriculture located at Randolph Center says of the institution: "The Vermont State School of Agriculture was established by an act of the Legislature in 1910, for the purpose of developing the various agricultural interests of our State. It is a school especially equipped and perculiarly fitted to train young men for living in the country. It demonstrates the possibilities of scientific agriculture as a business proposition and as an occupation the peer of all others in importance and comparable to any of them in dignity. In short, farming is clearly shown to be a profession in the highest and broadest sense and as such is worthy of the most faithful service and keenest study which any man can give to it. The chief aim of the school it to keep more of our strongest young men on Vermont farms.

"The courses of the school cover the entire field of agriculture. 
Strong general courses are given also in English, physics, chemistry, botany, law, and history. The technical courses include animal husbandry, agronomy, dairying, horticulture, poultry culture, bacteriology, blacksmithing, plumbing, carpentry, etc. The most up-to-date texts to be found are used in teaching the various subjects and the theoretical work of each course is reinforced and reduced to practice by a large amount of required work. In fact, the shops and dairy connected with the school are run by student labor, partly as laboratory work and partly as pay work.

"The tuition is free and the living expenses of a student with the advantages for self help which the school offers, are very low.

"A high school graduate who has maintained a high standard in scholarship during his high school career, may, upon getting the consent of the principal, complete the regular course of the school in one year. For others two years will be required.

"No examinations are required for entrance, but no student will be admitted who is not at least in his sixteenth year and who has not completed the work of the common schools.

"The school graduates a class of forty-four members this year, practically all of whom are already definitely located for the next year's work. The majority of these men will go back to their home farms for the present. The remainder have engaged to become testers in cow test associations, managers of farms, teachers of agriculture in high schools and farm hands. Of the forty-four men, only one intends to locate outside of Vermont and everyone of the forty-four plans to own a farm in Vermont at the earliest possible moment. This proves that the school is doing just what its establishers wanted it to do and with an additional appropriation of $\$ 30,000$, made by the last Legislature for new equipment and buildings, its success is assured.

"Write Prin. G. L. Green, Randolph Center, Vt., for catalogue."

The principal of the Lyndon School of Agriculture says: "The Lyndon School of Agriculture is designed to fit boys for practical farm work. We give them a two-year course, divided into theoretical and practical work. The theoretical work is given forenoons throughont the school year, which extends from September until June. The practical work is given for the same length of time during the afternoons. The boys stay on the school farm throughout the summer months and carry on all the farm operations.

"Boys enter this school on two systems. They may enter on the cash system and stay for the nine school months, or they may enter on the work system and receive credit for work, sufficient to defray their expenses. The cost of either system is $\$ 200$ per year.

"The school is well equipped with buildings and tools. Excellent representations of the different breeds of cattle are kept in the school barns. Arrangements have been made with the neighboring farmers for the use of their herds and flocks for demonstration purposes. 
"The Agricultural School is strictly a tarmers' school and it aims to educate students along the various lines of work that will be met with on the farm and in the home life. It is not intended to fit students for college, but to furnish a line of training that will be of immediate use in farming and its allied industries, like carpentry, blacksmithing, masonry and concrete work, preparing the students not only to do the farm work intelligently, but also to do for themselves practically all the other work in connection with the farm, such as the repairing of buildings from basement to roof and the repairing of wagons and machinery, in a general way making them independent of any outside skilled labor, and also putting them in a position to assist their neighbors whenever spare time may permit.

"A dairy barn and fifty hotbeds have been constructed by the boys and wagons and sleighs constructed by them have been exhibited at fairs and other public places. The school has a herd of registered Ayrshires, Jerseys, and Holsteins. The school farm corsists of 1,100 acres. The apple orchards of Speedwell Farms, containing 3,000 trees, are under the management of the school."

While Middlebury College is not a technical institution, it endeavors to give a broad cultural education without reference to particular industries. In the various scientific branches, however, there is constant reference to the industries of Vermont, especially agriculture.

The college catalogue shows that instruction is given in subjects bearing directly on agriculture, such as fungi and lichens, bacteriology, forestry, entomology, agricultural chemistry, surveying and plotting, highway construction, water supply, econonic geology of Vermont and agricultural geology. The new chemical laboratory will have a room entirely devoted to milk and water analysis.

Each winter recently the college has co-operated with the Addison County Agricultural Society in holding a farmers' institute at the United States Government Farm at Weybridge. Several experts from the Department of Agriculture have given most instructive addresses and conducted judging demonstrations. These have been largerly attended by the farmers of Addison County.

A Rural Life Conference was held from July 7th to July 13th, 1913, in connection with the regular summer session of Middlebury College.

\section{The College of Agriculture}

The State College of Agriculture which is a department of the University of Vermont is located in beautiful Burlington, a city that is popularly denominated the Queen City of Vermont. The buildings of the college are on high ground on the eastern border of the city and overlook Lake Champlain and the Adirondack mountains on the west and the Green mountains, with Mansfield and Camels Hump 
prominently on the landscape, on the east. The College of Agriculture is housed in a building called Morrill Hall, named after the great senator, Justin S. Morrill, which was the first real gift of the State to Agriculture, in honor of the senator who introduced the bill providing the national grant for the establishment of state colleges throughout the country.

It is the aim of the Department of Agriculture to impart to its students information both theoretical and practical which will enable them successfully to engage in agricultural pursuits, including practical farming, teaching, or research work as may be desired. 'The main object is to teach agriculture as a pure or an applied science; but not to neglect the practical aspects in every department of agricultural instruction. At the present time the several courses are sub-divided as follows: A course in agriculture and horticulture; a conrse in animal husbandry; a course in forestry; a course for the training of teachers in agriculture in the secondary schools. Instruction is given in these several subdivisions of the college work by men well prepared in their several lines. In agriculture, instruction is given in agricultural botany, soils and soil management, breeds, stock breeding, sheep, swine poultry, fruit, crops, including forage, fiber and cereal plants, stock feeding, dairying, farm management, farm mechanics and equipment. In botany, stress is laid upon the general principles of the subject, the systematical arrangement of plants and the fundamental application of botanical science to economic plants. In zoology, attention is given toward the development of a good understanding of the fundamental principles and various forms of animal life especially of insects. In veterinary science the anatomy of domesticated animals, the physiology, histology, and diseases of animals are taught. In horticulture, vegetable gardening, fruit growing, landscape gardening, plant breeding and greenhouse management are the leading features of the subject. In forestry, attention is directed to the management of timber lands, forest mensuration, botany of forest trees, mirsery management and reforestation. Instruction in dairying is given, concerning the production of milk, its chemical composition, physical properties, care and handling of milk, cream, production of milk, butter, cheese, ice cream, cream and milk testing.

The College of Agriculture is supported to a very large degree by government funds provided for in the land grant act of 1862. Of late the state has realized a part of its responsibilities and has made small appropriations for scholarships for students in the College of Agriculture and a two-year appropriation for extension service which is to include field and orchard demonstrations, exhibits at state fairs and elsewhere, farm trains, popular lectures, and general correspondence in all matters of an agricultural nature.

The Agricultural College staff contains the names of twelve men in addition to the President. These men derote much but not nearly all of their time to teaching work. Nearly all the members of the 
staff of the College of Agriculture are on the staff of the State Experiment Station, and the State Forester has obligations to the State of Vermont outside of his college and station duties. The college of Agriculture is only moderately well equipped for the work which it is designed to do, but with the increased state support it may become one of the best equipped colleges in the eastern United States.

Visitors are always welcome at the college. For the most part the buildings are open to interested parties, classes may be visited, buildings inspected and instructors interviewed. The greenhouses, dairies, botanical forestry and horticultural collections, also household economics rooms, are places of interest.

The college will soon put into operation an exrension service whereby men from the institution will be able to do visitorial work over the state, thus to be of more direct service to the rural public of Vermont.

\section{VERMONT AGRICULTURAL WXPERIMENT STATION}

The Vermont Agricultural Experiment Station is organized under an Act of the General Assembly of 1886 and by subsequent acts of 1887 and 1906 by the federal government. The experiment station was founded with the idea of carrying on scientific research in subjects in agriculture or subjects relative thereto. In the earlier days much work was less scientific and more popular but in later years it has, by nature of government regulations, had to confine itself more strictly to experimental and investigational subjects which have some bearing and direct application to Vermont agriculture. In addition to its scientific studies the station is prepared to analyze food, especially for domestic use, seeds, milk and dairy products which are deemed to be of benefit to the agricultural public of Vermont.

The experimental work is of several kinds and characters. The general importance of dairying in Vermont has seerned to justify special attention to research work along the lines relating to crop production, dairying and creamery management. To this end the station has the use of a 200 acre farm and a dairy in excess of 60 head of cattle with sufficient men to take charge of the several aspects of the work. Extended trials have been conducted concerning the value of different feeds and their effect on the quality and quantity of milk and on the life of the cow. Within recent years particular attention has been given to the development of work in forestry, especially related to the management of timber lands, the caring of nursery trees and the general management of forest areas. In horticulture, chief attention has been given to the study of the potato and its enemies and ways and means of meetıng the various problems arising in the production of this very important crop in Vermont. The work of the botanical staff relates to the study of diseases of cultivated plants, the culture of forage plants and the control of injurious weeds. The veterinarian has prosecuted farreaching studies of the diseases of dairy cows. The analysis of ferti- 
lizers, dairy feeds, and the testing of creamery glassware constitutes a part of the numerous duties of the chemist of the station.

'The station has published bulletins to the number of 166 , many of which are of an entirely scientific nature by reason of federal regulation, but none the less valuable bulletins which have been sent out to interested parties in the state. 'The usual size of the edition at present is 15,000 copies and there are at present 9000 names of Vermonters on the mailing list. Publications are not issued regularly but when a piece of work is completed and ready for presentation to the agricultural public. Bulletins of the station are free and mailed upon request.

The Experiment Station is housed for the most part in Morrill Hall and under the same roof with the College of Agriculture. Interested parties are welcome to visit the research laboratories, barns, dairy, greenhouses, and other buildings.

\section{MISCELLANEOUS}

Vermont is a healthful state. The air is pure and invigorating, the water supplies are exceptionally good, and the state is remarkably free, owing to its elevation, from unhealthful natural conditions. Deaths from typhoid decreased in Vermont, from 1885 to $1909,57.7$ per cent, compared with the preceding twenty-five year period. Deaths from tubercular diseases decreased 31.6 per cent from 1885 to 1909 , compared with the period from 1860 to 1884. Fatal cases of diphtheria are very rare in Vermont.

In the matter of education Vermont leads all the states of the Union in the record of school attendance, with 927 children out of every thousand in public or private schools, according to a recent report made by the division of education of the Russell Sage Foundation. Vermont's rank among the forty-eight states is twelfth in educational advancement. For each $\$ 100$ of wealth, Vermont spends forty cents for education, ranking ninth in this respect.

It is possible to develop many features not alluded to. For example, more than $\$ 20,000$ was paid out in September and October and the first half of November, 1910, for the gathering of wild ferms in the Bennington county towns of Woodford, Stamford, Searsburg, and Readsboro. These ferns are kept in cold storage for the use of florists. Ginseng is cultivated in some parts of Vermont.

It is possible for farmers who desire to take summer boarders to make considerable money by so doing and many hill farms may provide sites for summer homes to good advantage.

With the vast amount of available water power in the state, it is possible to develop electricity at comparatively small cost. Already some farmers are lighting their houses and barns with electricity and are using electric power to run ensilage cutters and washing machines, operate churns, and for a great variety of purposes. This use of electricity is likely to become more general in surall communities as well as 
in cities and villages, thus adding materially to the comforts and conveniences of rural life.

\section{SOME EXAMPLES OF VERMIONT FARMING.}

A few examples of successful Vermont farming are given herewith. They are chosen at random and many others equally as good, and perhaps much better, might be secured.

Luke Fisher, of Cabot, now a retired farmer, took his father's farm, underdrained the wet, soggy portions, cultivated the land so successfully that it produced five times as much as it did when hecommenced in 1869, established a fine dairy, and demonstrated what can be done with what looks at the start like an unpromising Vermont farm.

W. B. Wheelock of Colchester, after working several years in a ereamery, bought a small farm and put on ten cows. In order to bring the cattle through the first winter he had to kuy $\$ 134$ worth of hay. He read with care and profit the bulletins of the Vermont Experiment Station and put in practice so far as possible modern scientific methods. In a few years he was able to winter twenty head of cattle and a horse and is now getting into thoroughbred stock.

C. J. Barbour, of Bridport, Vt., a rural letter carrier, within the past five years has purchased two farms, one of two hundred acres and the other of three hundred acres. The first he rents and the second he has stocked with young eattle and manages it himself. The past spring he sold 33 three-year-old steers grown on the farm, for $\$ 55$ each. He writes as follows: "I would say to the young man who is thirty, temperate in all things and willing to work, you need not be afraid to buy a farm right here in Vermont at the present price of real estate, even though you are obliged to mortgage the same for two-thirds of the purchase price."

A few years ago Dr. T. R. Waugh of St. Albans purchased Rivernook Farm in Highgate, containing 400 acres, for which he paid $\$ 25,000$. He has erected an immense 16 -sided barn, 100 feet in diameter and in the center of the barn is a silo 19 feet in diameter and 40 feet high. There are 300 acres in one meadow. This meadow is a mile wide and one and one-half miles long, one of the longest in New England. It is overflowed every spring by the Missisquoi river. This farm produces 30 bushels of wheat to the acre and in 1910, 29 acres produced 4200 bushels of corn, some of which won prizes at the New England Corn Show.

A letter from J. N. Barss, superintendent of the Vermont State Industrial School at Vergennes, describing farming operations at that institution, may be of interest. Mr. Barss says: "Replying to your inquiry of May 9th I would say that unfortunately for us with our large family and the necessity of garden truck, our farm is almost entirely stiff, heavy clay. From personal experience we cannot report as favorably as we would like along many lines. We have tried some experiments with different kinds of grain, have raised for several different 
years from 40 to 42 bushels of wheat per acre, approximately 45 bushels of oats per acre, 50 bushels of oats and barley per acre, and about 60 bushels of spelts per acre. For three successive years our field corn averaged from 70 to 85 bushels of ears per acre.

"We are able to grow hay in almost any quantity. With an experience over a large section of eastern Canada and most of New England I have seen on several occasions hay crops on this farm beyond anything I have seen anywhere. The latter part of June, 1912, I was visited $\mathrm{b} y$ a man with 40 years experience in agriculture, who was just finishing a trip covering a large part of eastern Canada and part of New Ensland. I drove him through the fields on this farm and to my surprise he told me had never seen as heavy crops of hay as I had showed him that day.

"You must remember that we are not hay growers nor grain growers and that no one feature of agriculture can exclusively occupy our attention, as our business is the reformation of boys. We have gone far enough, however, in our experiments here to convince us that it would be difficult indeed to find a country where the same amount of capital, labor, and intelligence would produce greater results than in this section of Vermont.

"The results with our dairy are crippled by the fact that most of the boys who go out from here must go on farms and it is absolutely necessary that they should be milkers, therefore we have to break in many milkers which is a decided detriment to our herd. Even with this handicap our dairy shows a good profit with the money and time invested.

"Having spent the earlier" part of my life in the far-famed fruit region of the Annapolis valleys of Nova Scotia, and having spent many winters in packing and shipping fruit, my attention is forcibly called to the possibilities of apple growing in this state. We have heard much of late of the perfect condition for fruit growing on the Hero islands. Undoubtedly the conditions there are ideal, but my observation leads me to believe that there is no better fruitgrowing country in America than the foot-hills of our Vermont mountains. I believe that where the Champlain valley rises on to higher ground the slopes of the entire length of this valley would prove almost ideal for fruit culture.

"I am thoroughly convinced that there are as good agricultural opportunities for the young man in Vermont as anywhere in America today and I believe that for the average young man the openings in agriculture are better than in any other vocation."

Mrs. Carrie J. Nelson-Shackford of East Ryegate, was left a widow with a large family. By good management she paid off the mortgage and made a great success of her farm. During the last twenty years she has taken $\$ 547.42$ in prizes on her butter. Dairying is the principal business of the farm, from 50 to 60 cattle be- 
ing kept. High grade Jerseys constitute the herd and last year the price of butter averaged 34 cents per pound.

C. F. Smith of Morristown, a former master of the State Grange, has a fine dairy farm containing about 350 acres. His large barns contain room for over a hundred head of cattle and a large Boston hotel has taken his entire output of butter for many years.

The house and barns are lighted by electricity and an electric motor runs the cream separator, the milking machines, the ensilage cutter, the churn and the washing machine.

In 1885, A. A. Dunklee of Vernon, rented his father's farm of 100 acres and two years later he bought it for $\$ 3700$ giving a mortgage for the entire amount. When he began farming operations the place supported four cows, twenty sheep and one horse. Today the place supports 90 milch cows and enough young stock to bring the number up to 125, 7 horses and about 60 hogs. Mr. Dunklee specializes in the sale of cream and this averages probably $\$ 10,000$ a year. The average returns from the herd in recent years have been equal to from 350 to 380 pounds of butter each. There are four large silos on the place. Considerable sweet corn is grown for canning purposes, also cucumbers for a pickle factory.

T. G. Bronson of East Hardwick is one of the leading dairy farmers of Vermont. At the Vermont State Fair in 1908 this farm won the special $\$ 150$ cup offered for the best Jersey cow in the state. In 1909 this farm won another special cup at the Vermont State Fair for the best cow shown with two of her progeny and subject to a twenty-four hour butter fat test. The same year this herd won six champions and a total of 34 out of a possible 35 first premiums. Mr. Bronson is keeping five times as much stock and getting more than five times the income than he had when he started in 1887 .

A few Lamoille county illustrations have been furnished where it was desired that names should not be used. A-B-bought an $\$ 8000$ farm about twenty years ago and had only a little money he had earned by working several years for the owner. He married a good wife and has raised a large family of children. $\mathrm{He}$ has paid for the farm and for several years has had money in the bank. The value of the farm is probably $\$ 12,000$.

$\mathrm{H}-\mathrm{C}$ - worked by the day until he was forty years old. He bought a $\$ 3000$ farm on credit and had other debts at the time. The farm stock and tools are now paid for and the property is worth from $\$ 4000$ to $\$ 5000$.

F-B - bought a $\$ 5000$ farm and had only a little money to pay toward stock. In ten years he had the place paid for and now milks forty cows and has a milking machine and other modern improvements.

E-F- has a farm and stock which he has paid for with a little help in a few years. 
G-A- has a farm and stock worth nearly $\$ 10,000$; has money in the bank and is in indepcndent circumstances. He started with $\$ 2000$ capital.

The Ox Bow Farm in Newbury, on the Connecticut river, orned by Richard F. Darling, is called one of the best in the state. It consists of three separate meadows, two home pastures, and one large pasture several miles away on the hill. The Ox Bow meadow contains 130 acres; the Kimball meadow contains 165 acres, and a third meadow contains 40 acres. The three pastures contain, in the aggregate, 290 acres. The meadows are flooded every spring by the Connecticut river. The lower parts of the meadows yield from three to five tons to the acre of stock hay in two cuttings. Silos are used, not only for winter feeding, but to supplement the pastures in the summer. A yield of 50 or 60 bushels of oats to the acre is not unusual. Holstein cattle are kept on the farm. Mr. Darling eloses his letter as follows: "Farming on a good farm, while it is hard work, is certainly profitable and as the farm gains fertility, and we get better cattle, just so much more will be our income of health, wealth and happiness.'

The Billings farm at Woodstock is one of the best known farms of the state. Its manager, James D. Aitken, writes as follows: "Last season all our crops were raised from stable manure alone, no commercial manures being used. We plow all our land in the fall, turning under a liberal amount of well rotted stable manure. In spring plow again and thoroughly harrow.

"Our regular crops are hay, corn, oats and potatoes, and in addition we raise quite a lot of mangles, some turnips and carrots. Last season we had in addition three acres of winter wheat, which averaged 43 bushels per acre. Our corn acreage last year was less than usual, 30 acres, but generally we have from forty to fifty acres. From the 30 acres we husked 3,201 bushel baskets of sound mill corn. Potatoes, usually about two acres, and from the two acres last fall we had 534 bushels.

"Three acres of mangles averaged 32 tons per acre. Oats last year averaged $441 / 2$ bushels per acre. We are great believers in stable manures, so much so that in order to have stock enough to consume our hay and roughage and not to sell the same off the farm, we bought in August, 1911 a carload of yearling beef steers in Chicago. On arrival they were turned to pasture and ran until fall, then yarded and fed the hay and roughage, all they would eat, no grain. In the spring of 1912 they were again pastured until fall, then taken up and fed to fatten, sold in January and February of this year, and we know at a profit. They were fat, handsome two-year-old beef and brought the top price. They made us lots of manure and we were so well pleased with the experiment, that this past August we bought seventy-five head more. These will un- 
dergo the same treatment. This followed up will increase our fertilizing and perhaps will increase the average yield of crops.

"Too much Vermont cash goes out of the state for commercial manures, and too much hay is baled and shipped out. We run a dairy of 20 to 25 cows, but this and the natural increase does not begin to use up the forage crops."

The Fillmore Farms at Bennington, are owned by J. C. Colgate, a prominent New York business man. Mr. Colgate spends his summers here, makes frequent visits during the winter and maintains his voting residence here. A specialty is made of Horned Dorset sheep and Jersey cattle. These sheep have been prize winners all over the country for the past dozen years. This farm is run on a business basis, every part of it being carefully systematized and books are kept covering the receipts and expenses of every department.

Edward H. Everett was brought up in Bennington, remaining there until he grew to manhood, then he went to Newark, Ohio, where he made a fortune in the glass business. Returning two or three years ago he purchased a string of farms extending from Town hill in Bennington nearly to North Pownal. On the farms he has purchased he has set out orchards aggregating 42,000 trees at the present time. Of this number 36,000 are apple trees and the remainder pear, cherry, plum and peach. Mr. Everett is interested in the apple canning industry in Ohio. If the quality proves what he hopes, he expects to produce high grade table apples. If the quality should not be of the best, probably the apples will be shipped to the canning factory in Ohio.

\section{THE ANSWER TO THE QUESTION.}

This book opened with the question, "What inducements can Vermont offer an ambitious, wideawake farmer to settle in the Green Mountain state?" The portion of the book following this question is devoted almos: entirely to an attempt to answer it. Whether the question has been answered satisfactorily or unsatisfactorily, whether the showing made for the state is good, bad or indifferent, are matters which must be left to the judgment of the individual reader.

A few facts stand out so clearly that they cannot well be challenged. The fertility of the soil of Vermont is indicated by reports of crop yields made by the United States government, covering a period of more than forty years, which show that very few states in the Union equal Vermont in the average yield per acre of staple crops or in the average price received for the same. Vermont's proximity to markets requires only a rudimentary know]edge of geography to demonstrate. 'The comparatively low price of Vermont farm lands, coupled with the great agricultural opportunities of the state, certainly furnish inducements that no prospective purchaser of a farm can afford to ignore. There is money to be made and comfort to be enjoyed in farming in Vermont. 


\section{AGRTCULTURAL PUBLICATIONS}

The following lists of free publications bearing relationship to Vermont agrieultural operations may be of service to those who contemplate farming operations within her borders. They may be obtained for the asking. Care should be taken to write to the proper place for several lists are cited. The black face statement at the beginning of each list will serve to identify them.

I. United States Department of Agriculture: Division of Publications, Washington, D. C.

II. Vermont Experiment Station, Burlington, Vt.

III. Extension Service: College of Agriculture, University of Vermont, Burlington, Vt.

IV. Commissioner of Agriculture, St. Albans, Vt.

\section{if. Plant production.}

\section{Agronomy.}

(Including Soils, Fertilizers, Field Crops, and Crop Pests.)

Farmers' Bulletins. 1

35. Potato Culture. Pp. 24, figs. 2.

164. Rape as a Forage Crop. Pp. 16, fig. 1.

192. Barnyard Manure. Pp. 32, figs. 4.

224. Canadian Field Peas. Pp. 16, figs. 4.

229. The Production of Good Seed Coin. Pp. 23, figs. 10.

245. The Renovation of Worn-out Soils. Pp. 16.

250 . The Prevention of Stinking Smut of Wheat and Loose Smut of Oats. Pp. 16, figs. 7 .

253. The Germination of Seed Corn. Pp. 16, figs. 4.

257. Soil Fertility. Pp. 40, tigs. 2.

266. Management of Soils to Conserve Moisture. Pp. 30, figs. 7.

289. Beans. Pp. 28, figs. 12. (North.)

313. Harvesting and Storing Corn. Pp. 29, figs. 17.

339 . Alfalfa. Pp. 48 , figs. 14.

362. Conditions Affecting the Value of Market Hay. Pp. 29, figs. 7.

372. Soy Beans. Pp. 26, figs. 6 .

406. Soil Conservation. Pp. 15.

410. Potato Culls as a Source of Industrial Alcohol. Pp. 40,figs. 10.

414. Corn Cultivation. Pp. 32, figs. 25.

415. Seed Corn. Pp. 12, figs. 23.

420. Oats: Distribution and Uses. Pp. 24, figs. 4.

421. Control of Blowing Soils. Pp. 23 , figs. 10.

424. Oats: Growing the Crop. Pp. 44,figs. 13.

428. Testing Farm Seeds in the Home and in the Rural School. Pp. 47, figs. 32 .

443. Barley: Growing the Crop. Pp. 48, figs.17.

455. Red Clover. Pp. 48, figs.25.

464. The Eradication of Quack Grass. Pp. 11, figs.6.

485. Sweet Clover.

507. The Smuts of Wheat, Oats, Barley and Corn.

508. Market Hay.

515. Vetches.

518. Winter Barley.

523. Tobacco Curing.

Doc. 441. Commercial Fertilizers: Their Uses and Value. Pp.- .

631. Farm Fertilizers. Pp. 8. Bureau of Entomology Circulars.

87. The Colorado Potato Beetle. Pp. 15, figs. 6. 
Yearbook Reprints.

456. Cropping System for Stock Farms. Pp. 14. (1907.)

488. Some Things that the Grower of Cereals and Forage Crops Should Know About Insects. Pp. 22, pls. 3, figs. 17. (1908.)

494. The Development of Farm Crops Resistant to Disease. Pp. 10, pls. 2. (1908.)

495. Soil Mulches for Checking Evaporation. Pp. 8,figs. 7. (1908.)

507. The Function and Value of Soil Bacteria. Pp. 7, figs. 2. (1909.)

530. Nitrogen-Gathering Plants. Pp. 8,pls. 8. (1910.)

357. Insect enemies of Tobacco in the United States. Pp. 20, pl. 1, figs. 13. (1910.)

1 See also many bulletins in the list under Experiment Station Work,p 22.

\section{Horticulture.}

Farmers' Bulletins. 1

61. Asparagus Culture. Pp. 40. tigs. 17.

113. (Rev.) The Apple and How to Grow It. Pp. 32, figs. 10.

154. The Home Fruit Garden: Preparation and Care. Pp. 16, figs. 6.

156. The Home Vineyard with Special Reference to Northern Conditions. Pp. 22, figs. 15.

157. The Propagation of Plants. Pp. 24, figs. 22.

176. Cranberry Culture. Pp. 20, figs. 12.

181. Pruning. Pp. 39, figs. 25.

185. Beautifying the Home Grounds. Pp. 24, figs. 8.

195. Annual Flowering Plants. Pp. 48, figs. 55.

198. Strawberries. Pp. 24, figs. 15.

213. Raspberries. Pp. 38, figs. 25.

220. Tomatoes. Pp. 32, figs 13.

231. Spraying for Cucumber and Melon Diseases. Pp. 24, figs. S.

243. Fungicides and Their Use in Preventing Diseases of Fruits. Pp. 32 , figs. 17.

248. The Lawn. Pp. 20, figs. 5.

254. Cucumbers. Pp. 30, figs. 14.

255. The Home Vegetable Garden. Pp. 47, figs. 34 .

282. Celery. Pp. 36 , figs. 16.

283. Spraying for Apple Diseases and the Codling Moth in the Ozarks. Pp. 42, figs. 7.

284. Insect and Fungus Enemies of the Grape East of the Rocky Mountains. Pp. 48 , tigs. 35 .

354. Onion Culture. Pp. 36, figs. 20.

407. The Potato as a Truck Crop. Pp. 24.

433. Cabbage. Pp. 23, figs. 11.

434. The Home Production of Onion Seed and Sets. Pp. 24, figs.12.

440. Spraying Peaches for the Control of Brown-rot, Scab, and Curculio. Pp. 40 . figs 14.

453. Danger of General Spread of the Gipsy and Brown-tail Moths Through Imported Nursery Stock. Pp. 22, figs. $\%$

460. Frames as a Factor in Truck Growing. Pp. 29, figs. 12.

482. The Pear and How to Grow It.

488. Diseases of Cabbage and Related Crops and Their Control.

491. The Profitable Management of the small Apple Orchard on the General Farm.

492. The More Important Insect and Fungous Enemies of the Fruit and Foliage of the Apple.

494. Lawns and Lawn Soils.

521. Canning Tomatoes at Home and in Club Work.

Bureau of Entomology Circulars

42. How to Control the San Jose Scale. Pp. 6. 
121. The Oyster-shell Scale and the Scurfy Scale. Pp. 15, figs. 2.

124. The San Jose Scale and Its Control. Pp. 18, figs. 10. Yearbook Reprints.

47. Small-fruit Culture for Market. Pp. 12,pl, 1. (1895.)

197. How Birds Affect the Orchard. Pp. 14, figs. 5. (1900.)

261. The San Jose Scale: Its Native Home and Natural Enemy. Pp. 20, pls. 6, figs. 3. (190\%)

266. Top Working Orchard Trees. Pp. 14, pls. 4, figs. 8. (1902.)

293. The Cultivation and Fertilization of Peach Orchards. Pp. 20, pls.6, (1902.)

386. The Principal Insect Enemies of the Peach. Pp. 24, pls. 7, figs. 7. (1905.)

387. The Handling of Fruit for Transportation. Pp. 14, pis. 4. (1905.)

388. Meadow Mice in Relation to Agriculture and Horticulture. Pp. 14, pls. 4, fig. 1. (1905.)

433. Lime-sulphur Washes for the San Jose Scale. Pp. 18. (1906.)

480. Information about Spraying for Orchard Insects. Pp. 22, pls. 5. (1908.)

504. Plants Useful to Attract Birds and Protect Fruit. Pp. 11. (1909.)

519. Prevention of Frost Injury to Fruit Crops. Pp. 7, pl. 1, fig. 1. (1909.)

546. Cooperation in the Marketing and Handling of Fruit. Pp. 20. (1910.)

\section{Forestry.}

Farmers' Bulletins.

99. Three Insect Enemies of Shade Trees. Pp. 30, figs. 11.

173. A Primer of Forestry. Part I: The Forest. Pp. 48, figs. 33.

228. Forest Planting and Farm Management. Pp. 22, figs. 3.

358. A Primer of Forestry. Part II: Practical Forestry. Pp. 48, figs. 25.

(See also Bulletin 276 in the list under Experiment Station Work, p.23)

468. Forestry in Nature Study. Pp. 43, figs. 13.

Forest Service Circulars.

25. Forestry and the Lumber Supply. Pp. 14.

61. (Rev.) How to Transplant Forest Trees. Pp. 4.

69. Forest Planting Leafiet. Pp. 4.

140. What Forestry Has Done. Pp. 32.

157. A Primer of Conservation. Pp. 24.

165. Practical Assistance to Owners of Forest Lands and to Tree Planters. Pp. 7.

166. The Timber Supply of the United States. Pp. 24. figs. 6.

167. The Status of Forestry. Pp. 29.

171. The Forests of the United States: Their Use. Pp. 25.

180. Lumber Saved by using Odd Lengths. Pp. 5.

\section{Yearbook Reprints.}

112. Trees of the United States Important in Forestry. Pp. $26 . \quad$ (1897.)

268. Some of the Principal Insect Enemies of Coniferous Forests in the United States. Pp. 18, pls. 2, figs. 10. (1902.)

270. Practicability of Forest Planting in the United States. Pp. 12, pls. 4. (1902.)

274. Influence of Forestry upon the Lumber Industry. Pp. 3. pls. 3. (1902.)

327. Insect Injuries to Hardwood Forest Trees. Pp. 16, figs. 17. (1903.)

329. The Relation of Forests to Stream Flow. Pp. 10. (1903.)

355. Insect Injuries to Forest Products. Pp. 18, figs. 14. (1904.)

376. How to Grow Young Trees for Forest Planting. Pp. 10, pls. 1, fig. 1. (1905.) 
381. Insect Enemies of Forest Reproduction. Pp. 8, figs. 9. (1905.)

434. National Forests and the Lumber Supply. Pp. 6. (1906.)

442. Notable Depredations by Forest Insects. Pp. 16. (1907.)

523. Injuries to Forest Trees by Flat-headed Borers. Pp. 6, figs. 12 . (1909.)

525. The management of Second-growth Sprout Forests. Pp. 16, pls. 2 (1910.)

534. Progress in Saving Forest Waste. Pp. 16, pls. 3. (1910.)

542. Injuries to Forests and Forest Products by Round-headed Borers. Pp. 20, figs. 12. (1910.)

548. Fire Prevention and Control in the National Forests. Pp. 16, pls. 6. $(1910$.

1 Circulars dealing with the more important forest trees may be had by writing the Forest Service, U. S. Department of Agriculture, Washington, D. C.

\section{ANIMAL PRODUC'TION.}

\section{Farm Animals.}

Farmers' Bulletins. 1

22 (Rev.) The Feeding of Farm Animals. Pp. 40.

49. Sheep Feeding. Pp. 24.

71. Essentials in Beef Production. Pp. 24, figs. 17.

96. Raising Sheep for Mutton. Pp. 48, figs. 18.

170. Principles of Horse Feeding. Pp. 44.

205 (Rev.) Pig Management. Pp. 40, figs.22.

206. Milk Fever and Its Treatment. Pp. 16, figs. 2.

346. The Computation of Rations for Farm Animals by the Use of Energy Values. Pp. 32.

350. The Dehorning of Cattle. Pp. 14, figs. 6.

351. The Tuberculin Test of Cattle for Tuberculosis. Pp. 8.

379. Hog Cholera. Pp. 23 , figs. 3.

438. Hog Houses. Pp. 25, figs. 21.

439. Anthrax with Special Reference to Its Suppression. Pp. 16. Bureau of Animal Incustry Circulars.

23 (3. Rev.) Directions for the Use of Blackleg Vaccine. Pp. 8, figs.3. 31 (3. Rev.) Blackleg: Its Nature, Cause, and Prevention. Pp. 24, fig.1.

63. A Review of Some Experimental Work in Pig Feeding. Pp. 49.

68 (Rev.) Diseases of the Stomach and Bowels of Cattle. Pp. 10.

78. Glanders and Farcy. Pp. 12.

89. The Preparation of Emulsions of Crude Petroleum (for cattle parasites). Pp. 4.

94. Foot Rot of Sheep. Pp. 20, fig. 1.

102. Stomach Worms in Sheep. Pp. 7.

105. Baby Beef. Pp. 105 , pl. 1, figs. 5.

113. Classification of American Carriage Horses. Pp. 4.

137. The Preservation of Our Native Types of Horses. Pp. 59, p1. 1, figs. 19.

141. Foot-and-mouth Disease. Pp. 8.

144. Tuberculosis of Hogs: Its Cause and Suppression. Pp. 32 , pls. 4.

157. The Prevention of Losses among Sheep from Stomach Worms. Pp. 10.

163. The Regeneration of the Morgan Horse. Pp. 14, figs. 2.

165. Methods for the Eradication of Gid. Pp. 29, figs. 14.

175. The Control of Bovine Tuberculosis. Pp. 27.

178. Breeding Horses for the United States Army. Pp. 13.

Bureau of Plant Industry Circulars.

74. The Sulphur Bleaching of Commercial Oats and Barley. Pp. 13, figs. 4 
Bureau of Entomology Circulars.

15. The Horn Fly. Pp. 13, figs. 6.

Yearbook Reprints.

15. Some Practical Suggestions for the Suppression and Prevention of Bovine Tuberculosis. Pp. 14. (1894.)

456. Cropping System for Stock Farms. Pp. 14. (1907.)

484. Recent Work of the Bureau of Animal Industry Concerning the Cause and Prevention of Hog Cholera. Pp. 12. (1908.)

1 See also Bulletins $107,119,144,222,225,244,251,273,316,366$, 381 , and 451 in the list under Experiment Station Work, pp. 22-25.

\section{Poultry.}

Farmers' Bulletins. 11

51 (Rev.) Standard Varieties of Chickens. Pp. 48, figs. 42.

64 (Rev.) Ducks and Geese. Pp. 55, figs. 37.

177 (Rev.) Squab Raising. Pp. 32, figs. 11.

200. Turkeys. Pp. 40, figs. 12 .

234. The Guinea Fowl. Pp. 24,figs. 3.

236 . Incubation and Incubators. Pp. 32, figs. 11.

287. Poultry Management. Pp. 48, figs. 14.

355. A Successful Poultry and Dairy Farm. Pp. 40, figs. 7.

357. Methods of Poultry Management at the Maine Agricultural Experiment Station. Pp. 39, figs 10.

445. Marketing Eggs through the Creamery. Pp. 12.

Bureau of Animal Industry Circulars.

128. White Diarrhea of Chicks with Notes on Coccidiosis in Birds. Pp. 7. Bureau of Entomology Circular.

92. Mites and Lice on Poultry. Pp. 8, figs 6.

Bureau of Chemistry Circular.

61. How to Kill and Bleed Market Poultry. Pp. 15, figs. 5.

Yearbook Reprints.

552. The Effect of the Present Method of Handling Eggs on the Industry and the Product. Pp. 20, pl. 1. (1910.)

11 See also many of the bulletins in the list under Experiment Station Work, p. 22.

\section{AGRICULTURAL TECHNOLOGY.}

\section{Dairying.}

Farmers' Bulletins.

55 (Rev.) The Dairy Herd. Pp. 30.

106. Breeds of Dairy Cattle. Pp. 48, figs. 21.

166. Cheese Making on the Farm. Pp. 16, figs. 3.

201. The Cream Separator on Western Farms. Pp. 23.

280. A Profitable Tenant Dairy Farm. Pp. 16, figs. 3.

337. Cropping Systems for New England Dairy Farms. Pp. 24, figs. 2.

355. A Successful Poultry and Dairy Farm. Pp. 40, figs. 7.

413. The Care of Milk and Its Use in the Home. Pp. 20.

445. Marketing Eggs Through the Creamery. Pp. 12.

487. Cheese and Its Economical Uses in the Diet.

490. Bacteria in Milk.

Bureau of Animal Industry Circulars.

118. The Unsuspected but Dangerously Tuberculous Cow. Pp. 19, figs. 7. 126. A Simple Method of Keeping Creamery Records. Pp. 12.

130. Paraffining Butter Tubs. Pp. 6, fig. 1.

142. Some Important Factors in the Production of Sanitary Milk. Pp. 18 , figs. 12. 
143. Milk and Its Products as Carriers of Tuberculosis Infection. Pp. 7.

153. The Dissemination of Disease by Dairy Products. Pp. 57, tigs. 11.

158. Improved Methods for the Production of Market Milk by Ordinary Dairies. Pp. 12, figs. 11.

161. Whey Butter. Pp. 7.

166. The Digestibility of Cheese. Pp. 22.

170. The Extra Cost of Producing Clean Milk. Pp. 12, pls. 4, fig. 1.

175. The Control of Bovine T'uberculosis. Pp. 27.

\section{Yearbook Reprints.}

94. Utilization of By-products of the Dairy. Pp. 20. (1897.)

260. Dairying at Home and Abroad. Pp. 10, pls. 6. (1902.)

532. The Eradication of Cattle Tuberculosis in the District of Columbia. Pp. 16. (1910.)

536. The Grading of Cream. Pp. 8. (1910.)

\section{Miscellaneous.}

Farmers' Bulletins. 11

36. Cotton Seed and Its Products. Pp. 16.

252. Maple Sugar and Sirup. Pp. 36, figs. 9. (North.)

268. Industrial Alcohol: Sources and Manufacture. Pp. 45, figs. 10.

410. Potato Culls as a source of Industrial Alcohol. Pp. 40, figs. 10.

Yearbook Reprints.

534. Progress in Saving Forest Waste. Pp. 16, pls. 3. (1910.)

\section{AGRICULTURAL ENGINEERING.}

\section{Fal'm Buildings.}

Farmers' Bulletins. 111

32 (Rev.) Silos and Silage. Pp. 30, figs. 6.

126. Practical Suggestions for Farm Buildings. Pp. 48 , figs 28.

270. Modern Conveniences for the Farm Home. Pp. 48, figs. 26.

367. Lightning and Lightning Conductors. Pp. 20, figs 3.

438. Hog Houses. Pp. 29, tigs. 21.

475. Ice Houses.

480. Practical Methods of Disinfecting Stables.

Bureau of Animal Industry Circulars.

131. Designs for Dairy Buildings. Pp. 26 , figs. 32.

136. How to Build a Stave Silo. Pp. 18, figs. 18.

Forest Service Circular.

180. Lumber Saved by Using Odd Lengths. Pp. 5.

1 See footnote, p. 10.

11 See also Bulletins 119 and 124 in the list under Experiment Station Work, p. 22.

lll See also Bulletins $149,190,225,244$, and 317 in the list under Experiment Station Work, pp. 24, 25.

\section{Farm Mechanics.}

Farmers' Bulletins. 1

150. Clearing New Land. Pp. 24, figs. 7.

179. Horseshoeing. Pp. 30, figs. 18.

235. Preparation of Cement Concrete. Pp. 32, figs. 4.

269. Industrial Alcohol: Uses and Statistics. Pp. 29, figs. 10.

277. The Use of Alcohol and Gasoline in Farm Engines. Pp. 40, figs 12 .

303. Corn-harvesting Machinery. Pp. 32, figs. 20.

347. The Repair of Farm Equipment. Pp. 32, figs.23.

387. Preservative Treatment of Farm Timbers. Pp. 19, figs. 5.

403. The Construction of Concrete Fence Posts. Pp. 31, figs. 9. 
474. The Use of Paint on the Farm. Pp. 21, fig. 1.

481. Concrete Construction on the Livestock Farm.

Forest Service Circulars.

69. Fence-post Trees. Pp. 4.

142. Tests of Vehicle and Implement Woods. Pp. 29.

Bureau of Plant Industry Circulars.

44. Minor Articles of Farm Equipment. Pp. 15.

Yearbook Reprints.

457. Hygienic Water Supplies for Farms. Pp. 10, p]. 1, figs. 4. (1907.)

518. Comforts and Conveniences in Farmers' Homes. Pp. 1.1, figs. 6. (1909.)

\section{Road Improvement.}

Farmers' Bulletins.

311. Sand-clay and Burnt-clay Roads. Pp. 19, figs. 5 .

321. The Use of the Split-log Drag on Earth Roads. Pp. 14, figs. 5.

338. Macadam Roads. Pp. 39, tigs. 10.

505. Benefit of Improved Roads.

Office of Public Roads Circulars.

37. The Railroads and the Wagon Roads. Pp. 4.

89. Progress Reports of Experiments with Dust Preventives. Pp. 26.

90. Progress Reports of Experiments in Dust Prevention, Road Preservation, and Road Construction. Pp. 23.

91. Sand-clay and Earth Roads in the Middle West. Pp. 31, figs. 6.

92. Progress Reports of Experiments in Dust Prevention and Road Preservation. Pp. 32 .

296. Use of Mineral Oil in Road Improvement. Pp. 16, pls. 3, figs. 4.

412. Object-lesson Roads. Pp. 10, pls. 4. (1906.)

448. Dust Preventives. Pp. 10, pls. 4. (1907.)

535. Progress and Present Status of the Good Roads Movement. Pp. 12. (1910.)

538. Bituminous Dust Preventives and Road Binders. Pp. 12. (1910.)

1 See also Bulletins 149,353 and 381 in the list under Experiment Station work, pp. 23, 24.

\section{Drainage.}

Farmers' Bulletins.

187. Drainage of Farm Lands. Pp. 3S, tigs. 19.

524. Tile Drainage on the Farm.

\section{Irrigation.}

Farmers' Bulletins. 11

138. Irrigation in Field and Garden. Pp. 40, figs. 18.

158. How to Build Small Irrigating Ditches. Pp. 28, figs. 9.

Yearbook Reprints.

458. The Use of Small Water Supplies for Irrigation. Pp. 16, figs. 6.

495. Soil Mulches for Checking Evaporation. Yp.8, figs. 7.

514. Methods of Applying Water to Crops. Pp. 16, pl. 1, tigs. 10.

\section{AGRICULTURAL ECONOMICS.}

Farmers' Bulletins. 1

62. Marketing Farm Produce. Pp. 31, figs. 17.

228. Forest Planting and Farm Management. Pp. 22, figs. 3.

229. The Production of Good Seed Corn. Pp. 23, figs. 10.

242. An Example of Model Farming. Pp. 16, figs. 5.

272. A Successful Hog and Seed Corn Farm. Pp. 16, figs. 5.

280. A Profitable Tenant Dairy Farm. Pp. 16, figs. 3. 
319. Demonstration Work in Cooperation with Southern Farmers. Pp. 22.

325. Small Farms in the Corn Belt. Pp. 29, figs. 3.

337. Cropping Systems for New England Dairy Farms. Pp. 24, figs. 2.

355. A Successful Poultry and Dairy Farm. Pp. 40, figs. 7.

362. Conditions affecting the Value of Market Hay. Pp. 29, figs. 7.

365. Potato Growing in Northern Sections. Pp. 31, figs. 11.

370. Replanning a Farm for Profit. Pp. 36.

432. How a City Family Managed a Farm. Pp. 28, figs. 7.

437. A System of Tenant Farming and Its Results. Pp. 20.

454. A Successful New York Farm. Pp. 32, figs. 9.

460. Frames as a Factor in Truck Growing. Pp. 29, figs. 12.

Bureau of Animal Industry Circulars.

56. Facts Concerning the History, Commerce, and Manufacture of Butter. Pp. 24.

103. Records of Dairy Cows: Their Value and Importance in Economic Milk Production. Pp. 38, figs. 10.

140. The Egg Trade of the United States. Pp. 34, figs. 2.

178. Breeding Horses for the United States Army. Pp. 13.

Bureau of Plant Industry Circulars.

75. Agricultural Survey of Four Townships in Southern New Hampshire. Pp. 19, figs. 3.

Bureau of Statistics Circulars.

3. The Farmers' Interest in Finance. Pp. 15, figs. 2.

17. Government Crop Reports: Their Value, Scope, and Preparation. Pp. 16.

I See also Bulletins 114 and 190 in the list under Experiment Station Work, pp. $22,23$.

\section{Bureau of Entomology Circular.}

129. Insects in Their Relation to the Reduction of Future Supplies of Timber, and General Principles of Control. Pp. 10.

Office of the Secretary Circular.

25. The Unproductive Farm. Pp. 8. Office of Public Roads Circular.

37. The Railroads and the Wagon Roads. Pp. 4.

Yearbook Reprints.

122. Agricultural Production and Prices. Pp. 30.

304. The Nation's Farm Surplus. Pp.12. (1903.)

340. Opportunities in Agriculture. Pp. 30, pls. 3. (1904.)

430. Freight Costs and Market Values. Pp. 16. (1906.)

443. Does it Pay the Farmer to Protect Birds? Pp. 14, pls. 4. (1907.)

447. The Value of Insect Parasitism to the American Farmer. Pp. 20, figs. 24. (1907.)

456. Cropping System for Stock Farms. Pp. 14. (1907.)

474. The Economic Value of Predaceous Birds and Mammals. Pp. 8, pls. 3. (1908.)

475. The Wastes of the Farm. Pp. 20. (1908.)

487. Types of Farming in the United States. Pp. 15. (1908.)

502. Methods and Costs of Marketing. Pp. 14. (1909.)

509. Farming as an Occupation for City-bred Men. Pp. 9. (1909.)

525. The Management of Second Growth Sprout Forests. Pp. 11. (1910.)

528. Supply and Wages of Farm Labor. Pp. 16. (1910.)

533. The Game Market of To-day. Pp. 16, figs.2. (1910.)

546. Cooperation in the Marketing and Handling of Fruit. Pp. 20. (1910.)

552. The Effect of the Present Method of Handling Eggs on the Industry and the Product. Pp. 20, pl. 1. (1910.) 
553. Agricultural Statistics. Pp. 212. (1910.)

(Agricultural statistics of crop and animal products are published for each year and may be had on application to the Secretary of Agriculture.)

\section{General and Special 'Topics.}

Farmer's' Bulletins.

54 (Rev.). Some Common Birds. Pp. 48, figs. 22.

59. (Rev. Bee Keeping. Pp. 47, figs. 19.

86. Thirty Poisonous Plants. Pp. 32, figs. 24.

127 (Rev.). Important Insecticides. Pp. 45 , figs. 6.

183. Meat on the Farm: Butchering, Curing, and Keeping. Pp.37, figs.35.

188. Weeds Used in Medicine. Pp. 45, tigs. 31.

194. Alfalfa Seed. Pp. 14, figs. 55.

196. Usefulness of the American Toad. Pp. 16.

315. Progress in Legume Inoculation. Pp. 20.

330 . Deer Farming in the United States. Pp. 20 , figs. 2.

369. How to Destroy Rats. Pp. 20, figs. 5.

Experiment Station Work. 1

78. Humus in soils- WVinter protection of peach trees-SunflowersGrape juice and Sweet Cider, etc. Pp. 32, figs. 2.

84. Home-mixed fertilizers-Field selection of seed-Potatoes as foodBy-product of the dairy-Gape diseases of chickens, etc. Pp. 32. figs. 8 .

87. Soil moisiure and fertility-Cultivating v. cropping orchards- Transplanting trees-Food value of eggs-The toad as the farmers' friend, etc. Pp. 32 , tigs. 6.

92. Sugar beets on alkali soils-Replanting corn-Improved culture of potatoes-Second-crop seed potatoes-Pasteurization of milk for butter making, etc. Pp. 30 .

105. The tillering of grains-Fertilizers for gardens- Cereal breakfast foods-When to cut alfalfa-Spontaneous combustion of hay, etc. Pp. 32 , figs. 4 .

107. Fertilizer requirements for crops-Cost of raising calves-Feeding tuberculous milk to calves-Killing the germs of tuberculosis in milk-Dairy salt, etc. Pp. 32, figs.3.

114. Influence of salt on soil moisture-Extra early potatoes-Low-grade Paris green-Skim milk in bread making-- Profitable and unprofitable cows, etc. Pp. 28 , figs. 5.

119. Storing apples without ice-Cold storage on the farm-Cransplanting muskmelons-Effect of cotton-seed meal on the quality of butter-Protection against Texas fever, etc. Pp. 31, figs. 5.

122. Liming grass lands-Nuts as food-A pure-food law-Sellingeggs by weight-Unfermented grape juice, etc. Pp. 32 , figs. 5.

124. Distilled drinking water-Lime as a fertilizer-Weed destructionMaple sirup and sugar-Type of the dairy cow, etc. Pp. 32, figs. 6.

478. How to Prevent Typhoid Fever.

493. The English Sparrow as a Pest.

503. Comb Honey.

511. Farm Bookkeeping.

513. 50 Common Birds of Farm and Orchard.

516. The Production of Maple Sirup and Sugar.

525. Raising Guinea Pigs.

133. Value of stable manure-Alfalfa as a fertilizer-Liming acid soilsFrost-resisting strawberries-Ridding houses of flies, etc. Pp. 32 , tigs. 14.

144. Maintenance of soil fertility-Rotation of crops-Cattle and poultry foods-An improved cow stall, etc. Pp. 32, figs. 9. 
149. Culture of potatoes-Shrinkage of farm products-Soils and fertilizers for strawberries-Shelter for dairy cows-Feed mills and windmills, etc. Pp. 32 , tigs. 6 .

186. Losses in manure-Protection of peach buds-Dandelions in lawnsRations for laying hens-Keeping quality of butter, etc. Pp. 32 , figs. 9 .

190. Cost of eggs in winter-Profitable and unprofitable cows-Methods of milking-Coating cheese with paraffin-Ventilation of stables, etc. Pp. 32 , figs. 14 .

210. Hen manure-Varieties and qualities of wheat-Corn breedingInjuries to shade trees-Oak leaves as forage-The covered milk pail-Fertilizers for potatoes, etc. Pp. 32, figs. 7.

222. Home mixing of fertilizers-Weight per quart of feeding stuffs-Recent horse-feeding tests-Market classes and grades of swineSilage in place of grain for dairy cows, etc. Pp. 32, fig. 1.

225. Incompatibles in fertilizer mixtures-Value of flint varieties of corn -Buying and judging seed corn-Potato culture-Influence of feed on milk--Protecting cows from flies-A successful brooder house-Prevention of swelling in canned peas, etc. Pp. 32, figs. 6 .

233. Root systems of plants-Mushroom culture-Noodles-Condimental feeds-Beef v. dairy type for beef production-Feeding calves skim milk-Milk from diseased cows-Cider vinegar, etc. Pp. 32 , figs. 5.

237. Lime and clover-Plant-food requirements of fruit trees-Running out of seed wheat-Cereal breakfast foods-Damaged wheat as feed-Bedding for cows-Amateur poultry raising-Care of cream on the farm-Yeast as a disinfectant, etc. Pp. 32, figs. 6 .

244. Handling seed corn--Adaptation of seed corn-Effect of root nodules on composition of crops-Cooking quality of potatoes-Methods of feeding poultry-Covered yards for cows, etc. Pp. 32 , figs.6.

251. American sugar-beet seed-Profits from spraying potatoes-Durum wheat-Indoor v. outdoor feeding of steers-Cheap dairy rations-Cotton-seed meal for hogs, etc. Pp. 32, fig.1.

259. Use of commercial fertilizers-Spreading lime-Soil sterilizationWeights per bushel of seeds-Disease-resistant crops-Alfalfa meal as a feeding stuff-Milk fever-Nail wounds in horses' feet-Use of a cheap canning outfit, etc. Pp. 32 , figs. 3.

267. Breeding corn-Buckwheat-Grass mulch for orchards-Hardiness of young fruit trees-Protecting cows from flies, etc. Pp. 32, fig. 1.

273. Loss of nitrogen from soils-Manure as affected by feed-Continuous corn culture-Pasturing wheat-Rotting of potatoes in storage-Preserving eggs- Testing individual cows-Cleanliness in the dairy, etc. Pp. 32, figs. 4.

276. Improvement in peach growing-Alfalfa in the Eastern states-Improvement of grass land-Succotash as a soiling crop-Digestibility of fish and poultry--Honey vinegar-The farm woodlot, etc. Pp. 32 , figs. 2 .

296. Wells and pure water-Yure seed v. poor seed-Disease-resistant clover-Eradication of wild mustard-Seedless tomatoesHay box or fireless cooker-Insect enemies of shade trees, etc. Pp. 32 , figs. 4 .

305. Renewal of old orchards-Injury by Bordeaux mixture-Roots for farm animals-Cabbage as a stock feed-Cull beans as a feed for hogs-Healthy poultry, etc. Pp. 32.

309. Ice for household uses-Silage from frosted corn-Cooperation in marketing crops-Causes of death of young chicks-Snow for poultry, etc. Pp. 32 . 
316. Winterkilling of peach buds-Effect of fertilizers on the color of apples-Potato scab-Cooking cereal foods-Supplements to ccrn in hog feeding-Hoppers for poultry, etc. Pp. 32 , figs. 4.

317. Improving the convenience and comfort of the farn home-Cement pipe for irrigation-Increasing the productiveness of cornCatching hook for poultry, etc. Pp. 32 , figs. 6 .

329. Low-grade $\mathrm{v}$. high-grade fertilizers-Improvement of sandy soilsDry farming-Seed selection-Evergreens: Uses and culturePreparation of miscible oils-Cane sugar and beet sugar, etc. Pp. 32 , figs. 4

334. Plant breeding on the farm-Protits from tomato growing-The keeping of apples-Weed seeds in manure and feeding stuffsMarket classes and grades of horses and mules-Extraction of beeswax, etc. Pp. 32 , figs. 2 .

342. Conservation of soil resources-Potato breeding-Disk-harrowing alfalfa-The Montreal muskmelon-Storage of Hubbard squash -Preserving wild mushrooms-Cooking beans and other vegetables-A model kitchen, etc. Pp. 32, figs. 3.

353. Commercial clover seed-Growing potatoes under straw- Hens v. incubators-Preparing fowls for market- A cheap and efficient sterilizer-A cheap and efficient ice box--The power laundry on the farm, etc. Pp. 32, figs. 14.

360. Distance between corn hills-Street trees-Spraying for weedsMarker classes and grades of sheep-Hulled corn-Mixing fat into dough, etc. Pp. 32, figs. 6.

366. Treatment of muck soils-Corn breeding-Hook-worm disease in cattle-Effect of machine milking on cows-Milk supply of cities-The crow, etc. Pp. 32.

374. Inoculation and lime for alfalfa-Pruning ratundifolia grapesNative hays of the arid region-Bermuda grass-Short v. long feeding of beef cattle-Feeding work horses-Colony houses for poultry-Flour for baking powder biscuits, etc. Pp. 32, figs. 5 .

381. Methods and cost of clearing land-Calf feeding-Gasoline heated colony brooders-Measuring acidity in cheese making and butter making. Pp. 32 , figs. 9.

384. Early onions in the Southwest-Oleander poisoning of live stockWintering farm work horses-Alfalfa meal as a feeding stuffWhipped Cream-Farm butter making-Cement and concrete fence posts, etc. Pp. 32 , figs. 3.

388. Incompatibles in fertilizer mixtures-Principles of dry farmingMethods of seeding oats-Rolling $v$. harrowing winter wheatPruning-Bean anthracnose or pod spot-Jelly and jelly making, etc. Pp. 32 , figs. 7.

412. Wart disease of the potato-The typhoid or house fly-The forced molting of fowls-Pasteurization in butter making-Milling and baking tests with durum wheat, etc. Pp. 32 , figs. 6 .

419. Tillage v. sod mulch in orchards-Ear characters of seed corn-Seed disinfection-Blackleg of the Irish potato-Progress in horse breeding-Sweet potatoes. Pp. 24, figs. 4.

425. Commercial bean growing-Digestion experiments with range forage crops-Substitutes for oats for horses, etc. Pp. 24, figs 3.

430. Unusual $\mathrm{v}$. standard fertilizers-Symptoms of disease in plantsCondimental feeds-Feeding the dairy calf-Defects in cottage cheese-The Iowa silo. Pp. 24, figs. 14.

435. Water required for crops-Burning lime on the farm-Tomatoes for canning-Lime sulphur as a fungicide-Market classes and grades of meat-Lice on poultry-Neufchatel cheese. Pp. 24 , figs. 6 . 
451. Sterilizing tobacco-plant beds-Clover growing-Curing clover hay -The velvet bean-Draft horses-Care of mares and foals. Pp. 24, figs. 6 .

457. Low-grade fertilizers-Fighting the boll weevil-Hastening maturity of cotton with fertilizers-Early spring lambs-Production of sanitary milk-Lacto: A frozen dairy product. Pp. 24, fig. 1.

465. Cost of available nitrogen; management of marsh soils; weeder harrow for dry farms; V-shaped corn-stalk cutter; storage for root crops; danger in feeding root crops; sanitary care of swine; individuality of the cow; hatching and raising turkeys.

469. Lawns; fertilizing asparagus; turnips for sheep; loss of lambs; cost of market milk; propagation of starters; the plastered silo.

479. Screening cabbage seed beds; Spraying apple orchards; New type of spray nozzle; Preparation of corn for hogs; Experiments in beef production; Preparation of choice hams; Factors affecting fat in cream.

486. The feeding of a grand champion steer; The utilization of dairy by-products as food.

499. Top-dressing pastures; Making hay; A fresh-air brooder; Roosting closet for poultry; Exhibition contests of dairy products; Blind staggers of horses; Adobe as a building material; White and color washes.

504. Improvement of sandy soils; Utilization of roughage; Alfalfa and corn for lambs; Feeding alfalfa hay to swine; Cooperative herd testing; Cooperative cattle breeding; Losses due to low-grade cream; Disposing of waste dips; Care of farm machinery.

517. Promoting germination of seed; Cotton anthracnose; Asphaltum treatment for peach-tree borer; Raising and finishing beef calves; Open-shed feeding of steers; Four systems of dairy farming; Market eggs; Uses of the sweet potato; Vinegar making from waste grapes; Lighting farm houses.

Yearbook Reprints.

329. The Relation of Forests to Stream Flow. Pp. 10. (1903.)

364. Some Benefits the Farmer May Derive from Game Protection. Pp. 12. (1904.)

388. Meadow Mice in Relation to Agriculture and Horticulture. Pp. 14, pls. 4, fig. 1. (1905.)

392. Illustration of the Influence of Experiment Station Work on Culture of Field Crops. Pp. 16, fig. 1. (1905.)

443. Does it Pay the Farmer to Protect Birds? Pp. 14, pls. 4. (1907.)

447. The Value of Insect Parasitism to the American Farmer. Pp. 20, tigs. $24 . \quad(1907$.

457. Hygienic Water Supplies for Farms. Pp. 10, pl. 1, figs. 4. (1907.) 497. A Directory for Farmers. Pp. 25. (Corrected to 1909.)

(Agricultural statistics of crop and animal products are also published for each year and may be had on application to the Secretary of Agriculture.)

1 Experiment Station Work is a subseries of Farmers' Bulletins compiled from the published reports of the agricultural experiment stations and kindred institutions in this and other countries. In sending for bulletins of this series simply ask for Farmers' Bulletins, giving the serial number of the bulletin without specifying the topics treated in it.

\section{VERMONT EXPERIMENT STATION, BURLINGTON, VT.}

\section{Soils and Soil Management.}

Experiment Station

Farm Manures, No. 108; Soil Deterioration and Soil Humus, No. 135; 
Soil Physiography, No. 143; Soil Classifications and Adaptations, No. 154; Limes and Liming, No. 160; The Peat and Muck Deposits of Vermont, No. 165; Plant Food Combinations for Sundry Crops, Circular 7.

\section{Commercial Fertilizers.}

The Experiment Station Bulletin for the Current Year.

\section{Alfalfa Growing.}

Experiment Station.

No. $137 ; 19$ th Report; 20 th Report.

\section{Maple Products.}

Experiment Station.

Maple Sugar, No. 26; The Maple Sap Flow, No. 103; The Maple Sap Flow, No. 105 (scientific edition No. 103); Buddy Sap, No. 151; The Microorganisms of Maple Sap and Their Influence upon Maple Sirup, No. 167 (scientific); Maple Products, 20 th Report.

\section{Spraying.}

Experiment Station.

Preparation and Use of Sprays, No. 113; Sundry Matters, No. 136; Plant Diseases, Potato Spraying, Nos. 142, 153, 159, 162; 9 th Report; Bordeaux Mixture Preparation, 17 th Report; Spraying, 20 th Report.

weeds.

The Orange Hawkweed or Paintbrush, No. 56; The Viability of Weed Seeds in Fielding Stuffs, No. 138; The Grass and Clover Seed Trade in Vermont, No. 146; A Practicable Method of Killing VVitchgrass, No. 149; Paintbrush, Shrubby Cinquefoil and Sundry Matters, No. 136; Orange Hawkweed, 9 th Report; Killing Weeds with Chemicals, 13 th Report, 14th Report; Bird Vetch, 14th Report; Two New Weeds, 14th Report; Killing Weeds in Lawns, 15th Report; Weeds, 16 th Report; Shrubby Cinquefoil, 16 th Report; Weeds, 20 th Report.

\section{Insects.}

Household Pests, No. 43; The Forest Caterpillar, No. 76; Sundry Insects, No. 136, 9th Report; Apple Tree Borers, 16 th Report; Oyster Shell and San Jose Scales, 19 th Report; Insects, 20 th Report.

\section{Plant Diseases.}

Experiment Station.

Nos. $142,148,153,157,159,162,168$; 9 th Report, 13 th to 20 th Reports inclusive. A Resume of 20 Years Work, 20 th Report.

Seeds.

Experiment Station.

The Grass and Clover Seed Trade in Vermont in 1907-08; Impurities in Grass and Clover Seeds, 13 th Report, 17 th Report.

\section{Plant Growth.}

The Role of Anesthetics and Other Agents in Plant Forcing, No. 150 , 19 th Report; Carnation Growing, No. 163, 20 th Report; Tomato Growing, 17 th Report; Lettuce Growing, 17th Report, 18th Report; Rhubarb Folcing, 17th Report.

\section{Fruit Growing.}

Hybrid Plums, No. 67; Plum Culture, No. 89; Apple Growing in Addison County, No. 90; Winter Injury to Apple Trees, No. 119; Muskmelon Industry, 20th Report, No. 136, No. 169. Sundry Matters, No. 136. 
Montreal Market Muskmelon Industry, No. 169; Plum Propagation and Pollination, 13th Report; Apple Pollination, 13th Report; Plums, 13th Report; Disease of Greening Apples, 14 th Report; Plum Propagation, 14th Report, 15th Report; Hybrid Plums, 14th Report; 15th Report Grand Isle Apple Inventory, 14 th Report; Orchard Diseases, 15 th Report; Bridge Grafting, 17th Report; Winter Injury to Apple Trees, 18th Report; Influence of Stock on Scion, 1Sth Report; Miscellaneous Fruit Notes, 18th Report; Squash Storage, 20th Report; Fruit Growing 20th Report.

\section{Forestry.}

Experiment Station.

The Measurement of Saw Logs, No. 102; Planting White Pine in Vermont, No. 120; Forest Planting in Vermont, No. 132; Sundry Matters, No. 137; Preliminary Statement Concerning Forestry Problems in Vermont, No. 139; The Management of Vermont Forests with Especial Reference to White Pine, No. 156; The Damping Off of Coniferous Seedlings, No. 157; Hemlock in Vermont, No. 161; Locust Tree Cultivation, 15th Report; Tree Seedling Diseases, 20 th Report; Forestry, 20 th Report.

\section{Animal Husbandry.}

Experiment Station.

Pig Feeding, 19th Report, 20 th Report.

\section{Stock Feeding.}

Experiment Station.

Sundry Matters, No. 137; The Viability of Weed Seeds in Feeds, No. 138; The Composition and Nature of Commercial Feeding Stuffs, No. 144; Principles and Practice of Stock Feeding, No. 152; Concerning Feeding Standards, No. 158; Condimental Feeds, No. 164; Analyses of Feeding Stuffs, Nos. 144, 152, 158, 164; A Poisonous Plant-the Common Horsetail, No. 95; Apple Pomace a Good Feed for Cows, No. 96; Vermont Grasses and Clovers, No. 94; The Effect of Frost on Silage Corn, 19th Report; Stock Feeding in General, 20 th Report.

\section{Dairy Husbandry.}

Experiment Station.

Tests of Cows at Vermont State Fair, No. 17; Sundry Matters, No. 137; Apple Pomace a Good Food for Cows, No. 95; A Poisonous Plant-the Common Horsetail, No. 96; Paying for Separator Cream at Creameries, No. 100; The Testing of Cows, No. 128; Principles and Practice of Cream Making, No. 155; Variations in Milk, 9th Report; Herd Records, 9th, $13 \mathrm{th}, 16 \mathrm{th}, 17 \mathrm{th}, 18 \mathrm{th}$ Reports; Dairy Feeding (experiments) 9 th, 13 th to 20 th Reports inclusive; Food Effects on Butter Quality, 13 th Report, 14th Report, 15th Report; Testing Babcock Apparatus, 14th Report; Comparison of Feeding T'rial Methods, 14th Report, 15th Report; The Change from Barn to Pasture, 15th Report; The Influence of Change of Feed on the Composition of milk, 18th Report; Methods of Milking, 18th Report; Udder Conformation and Milk Production, 18th Report; The Effect of Age on the Yield and Quality of Milk, 19 th Report; Dairy Husbandry, 20th Report.

\section{Nature Study.}

\section{Experiment Station.}

Vermont Grasses and Clover, No. 94; Vermont Shrubs and Woody Vines, No. 145. (It is hoped that a new edition of No. 73 , Trees of Vermont, may be issued within a year.)

Drug Plant Cultivation, 20 th Report. 


\section{VERMONT FARMS AND RESIDENTIAL PROPERTIES}

\section{FOR SALE}

The following list of Vermont farms and residential properties are in accordance with deseriptions of the owners sent to this department.

While the department has personal knowledge respecting some of these properties, yet there has been no opportunity to verify the statements of the owners of all of the properties, and to prospective purchasers who are unfamiliar with farm values, it is respectfully suggested that the advice of the state department of agriculture be obtained before purchasing such farms.

The address of the Commissioner of Agriculture is Elbert S. Brigham, St. Albans, Vt.

\section{ADDISON COUNTY.}

\section{Bridport}

Farm of 128 acres; Pasture, 50; suitable for cultivation, 78. House, $35 \times 45$; L,35 × 25; 12 rooms. Woodshed, wagon barn and horse barn, adjoining L, $60 \times 40$; cow barn, $32 \times 85$, with tool shed attached, $30 \times 32$; barn, $15 \times 85$, with hennery, 1 open shed, closed sheds for sheep and calves, 1 box stall; hog house, $16 \times 16$. Buildings in good repair. Good fences. Pasture watered by brook; spring, well and cistern water at house and barns. Will keep 15 cows and 5 horses. A few apple, cherry, plum and pear trees. R. F. D. and telephone. P. O., 2 miles; nearest railroad station, Crown Point, N. Y., $4 \frac{1}{2}$ miles. Price, $\$ 4,200$. Address Mrs. Alice Myrick or Myrick Brothers, Bridport.

\section{Bristol}

Farm, located in town of Bristol, near main road to Starksboro. 80 acres; pasture, 25; woodland, 30 ; other acreage, 25 ; suitable for cultivation, 40. Estimated value of wood and timber, $\$ 400$. 10 room house, $26 \times 30$ feet; with L, $20 \times 12$ feet; in good repair. Two barns, $26 \times 36$, and $18 \times 26$ feet, in good repair. Fences in good condition. 135 ton silo. Will keep 6 cows and 2 horses. Well water at the house and brook running through the farm. Orchard of 9 large fruit trees, Greenings and early fruit, also about 20 young trees beginning to bear. Soil sandy loam-some gravel. Fine grain and fruit land. Meadows are nearly all level and smooth. Fine place for poultry and small fruit. Rairoad Station, Bristol, 6 miles distant. Post Office, Starksboro, $21 / 2$ miles distant. R. F. D. Price, $\$ 1300$; cash, $\$ 650$; balance on interest at 5 per cent. A. H. Palmer, R. F. D. No. 1, Starksboro, Vt.

\section{Bristol}

Attractive home for sale on main street of Bristol between railway station and business section; lot $5 \frac{1}{2}$ rods frontage, 10 rods deep; large two-story house, large veranda on two sides, porte cochere constructed in part of rock-faced marble, house ten feet between joints, slate roof, large front reception hall with fire-place; hall separated by portieres from front parlor, back parlor, good sized library, dining room, kitchen, pantry and back shed. Oak staircase leads to second floor which contains five sleeping rooms, one of which opens on an upper veranda. Two rooms may be used as a suite with sitting room and 
bedroom. The house is heated by a hot air furnace and is lighted by electricity. A good barn, 24 x 30 ft. in size with basement, water and electric lights. Some fruit on lot. Bristol is one of the prettiest of Vermont villages, with fine mountain views, in a splendid farming region. Property will be sold for $\$ 5000$. Address J. W. Page, Burlington, Vt.

\section{Cornwall}

Farm, 300 acres: Pasture, 75; woodland, 40; suitable for cultivation, 300 . Estimated value of wood and timber, $\$ 500$. 10 room house, $28 \times 32$ feet; with L, $50 \times 28$ feet; in good repair. Barn, with cellar, $40 \times 32$ feet, in good repair. Fences in good condition. 175 ton silo. Will keep 50 cows and 12 horses. Running water. The orchard contains 125 varieties of fruit trees. The above mentioned barn is a cow barn; the horse barn is $40 \times 28$ feet, with cement floor; 10 stalls and two box stalls. Sheep barn, $60 \times 28$ feet. 1 tenement house with 8 rooms. All the buildings are slate roofed. This place will keep 50 cows, 12 horses, 60 sheep and will cut 60 tons of hay. Railroad Station, Middlebury, Vt., 5 miles distant. Post Office, Middlebury, Vt. R. F. D. Telephone. Price, 12,500 ; cash, $\$ 4000$; balance on interest at 5 per cent. Address Box 116, Middlebury, R. F. D. No. 2.

\section{West Ferrisburg}

"Elmhurst," W. Ferrisburg, on Lake Champlain. 150 acres; pasture 30 ; woodland, 20 ; other acreage, 10 ; suitable for cultivation, 90 . Estimated market value of wood and timber, $\$ 1500.12$ room house, $30 \times 30$ feet; with L, $40 \times 22$ feet; in good repair. Barn, $70 \times 40$ feet in good repair. Fences in fair condition. 25 ton silo. Will keep 15 cows and 7 horses Good well water. úood orchard of 200 young hardy apple trees, mostly McIntosh Reds. "Elmhurst" has a large frontage on Lake Champlain and Otter Creek River. Artesian well of 50 gallon capacity, recently drilled. Many cottages nearby, which provide good market for milk, butter, eggs, etc. Excellent boating, tishing and hunting. Fine place for boys' camp, club or hotel. There are other barns, tool house, hen, wood and ice-houses and many tools that go with the farm. Photographs will be sent to parties desiring same. Railroad Station, Vergennes, 7 miles distant. Post Office, Vergennes, R. F. D. No. 3, 7 miles distant; carrier comes to farm. Telephone. Price, $\$ 7,000 ; \$ 3,000$ cash; balance on interest at 5 per cent. Will make special price to right party. Address R. W. McCuen, Vergennes, Vt.

\section{West Ferrisburg.}

Farm of 100 acres; pasture, 40; woodland, 15; other acreage, 13; suitable for cultivation, 46 ; loam and heavier soils; estimated market value of wood and timber, $\$ 600$. House, $26 \times 32 ; \mathrm{L}, 14 \times 16 ; 9$ rooms; in good repair. Barn, $30 \times 40$; in good repair; will keep 15 cows, 3 horses. Water, Otter Creek and two wells. Fences in fair condition. Orchard, 100 trees, Spy, McIntosh Red, Wealthy, Scott's Winter, Baldwin. Horse barn, granary, hen house, long tool shed; farming tools. 6 cows, one yearling heifer, 40 hens. Team of black mares. Harness, etc. Lumber for silo, other lumber included. Situated on Basin Harbor road, 3 miles from the city of Vergennes. Maple shade and nice surroundings. Borders Otter Creek. Steamboats pass. Level land. Far'm is called one of best in town. R. F. D. and telephone. Price, $\$ 4,000$. Address J. A. Kingsland, R. F. D. No. 3, Vergennes, Vt.

\section{Granville}

35 acre farm in Granville, pleasantly situated on the main road from Granville Corners to Hancock. Woodland, 25; other acreage, 10 ; suitable for cultivation, 10. Estimated market value of wood and timber, $\$ 200$. 
A large two-story, 10 room house in good repair, with rooms suitable for keeping roomers. Barn, 30 x 40 feet; in good repair. Fences are in good condition. 10 ton silo. Railroad station, Rochester or Braintree, 7 miles distant. Post office, Granville, Vt., 1 mile distant. R. F. D., telephone, star line. Price, $\$ 1500$. One-half cash; balance on interest at 5 per cent. H. C. Hubbard, Granville, Vt.

\section{Granville}

Good farm, one mile from school, church and store. 117 acres; pasture, 45; woodland, 25; other acreage, 47; suitable for cultivation, 35. Estimated market value of wood and timber, $\$ 200$. 7 room house, $20 \times 30$ feet; with L, $20 \times 40$ feet. Barn, $30 \times 56$ feet in fair repair. Fences in fair condition. Will keep 8 cows and 2 horses. Water in house and barn. Orchard consists of 150 grafted apple trees, 2 pear and 4 plum trees. Railroad station, Rochester, 8 miles. R. F. D. Telephone. Price $\$ 700$; cash, $\$ 500$; balance on interest at 5 per cent. A. F. Kennedy, Gianville, Vt.

\section{Leicestel}

Good farm in Leicester, Vt. 60 acres; pasture, 9; woodland, 5 ; suitaable for cultivation, all but woodland. 9 room house, $28 \times 30$ feet; with L, $20 \times 20$ feet, in good repair. Fences, in fair condition. Will keep 5 cows. Plenty of water. Apple orchard. Barn, $50 \times 30$ feet, with shed attached $20 \times 50$ feet. Horse barn, $40 \times 22$; wagon shed, wood shed and ice-house. Lime quarry on farm. This is a hay farm and will cut about 75 to 80 tons of hay. Railroad station, Leicester Junction, less than 1/4 mile distant. R. F. D. Price on application. Fred McIntyre, Leicester, Vt.

\section{Fast Middlebury}

18 room house for sale or to rent, furnished. 1 acre of land, nice lawn; cement walks; piazzas; mountain running water. All modern improvements. Barn; garden; ice house filled. Mail twice daily. Good roads for automobile or team. 4 miles to Lake Dunmore or Bread Loaf Inn. Apple orchard. Railroad Station, Middlebury, Vt. R. F. D. Matilda Baker, East Middlebury, Vt.

\section{Monkton}

Farm of 200 acres; pasture, 75; woodland, 75; suitable for cultivation, 50. Estimated value of wood and timber, $\$ 2000$. 8 room house, $30 \times 40$, in fair repair. Barn, $48 \times 74$, in good repair. Fences in fair condition. Horse barn, $28 \times 44$; besides a granary, hen house, milk house and hog pen. The farm will keep 20 cows and two or three horses. Spring, well and cistern water on the premises. Orchard of 100 apple and other fruit trees. Railroad Station, Bristol, Vt., 5 miles distant. R. F. D. Telephone. This farm is located at the four corners of the roads and has one of the best apple orchards in Addison County. The farm is being placed on the market because of the inability of the owner to carry on the same. If the purchaser will pay all cash, some personal property may be secured at the price mentioned. Piice, $\$ 4000 ; \$ 1000$ cash; balance on interest at 5 per cent. Address: Willis V. Farr, Agent, Burlington, Vermont.

\section{“"Hope Cottage," Orwell}

“Hope Cottage," Orwell, Vt. 10 acres land; pasture, 6 ; other acreage, 4 ; suitable for cultivation, 4.7 room house, $18 \times 28$ feet, with L, $14 \times 24$ feet in excellent condition. Barn, $18 \times 20$ feet with stable and carriage room attached, all in good repair. Will keep one cow and one horse. Plenty of water. A young sugar orchard. Fruit orchard of 75 trees. Near village, good school, church, market and stores. Well equipped for raising poultry. Fine location, good drainage, fine view. An ideal summer home. Railroad Station, Orwell, Vt., 2 miles distant. R. F. D. Telephone. Price, $\$ 2500$. Clyde L. Munger, Orwell, Vermont. 


\section{Starksboro}

200 acres; pasture for 25 head; woodland, 75 ; other acreage, 25; suitable for cultivation, 100 . 9 room house, $60 \times 30$ feet, with L, $25 \times 20$ feet, in fair condition. Horse barn, $75 \times 30$ feet in good repair. Fences in good condition. 40 ton silo. Will keep 25 cows and 3 horses. Spring water. Small orchard. Cow stable and hay barn, 66 feet long, stable for young cattle and sheep 36 feet long. Ice house, $12 \times 14$. Hen house and pig pens $20 \times 30$. Sugar house, $16 \times 30$, good arch. 1000 sugar trees. Very well watered. Full view of Lake Champlain and Four Brother islands. One of the most beautiful summer resorts in the Green Mountains. Level farm. Running water at house and barn. Railroad Station, Bristol, 10 miles distant. R. F. D. Telephone. Price $\$ 4000$. cash, $\$ 2000$; balance on interest at 5 per cent. F. M. Walston, Starksboro, Vermont.

\section{Vergennes}

Farm of 20 acres; pasture, 5; suitable for cultivation, 15.9 room house, $36 \times 40$ teet, slate roof, in good repair. Barn, $26 \times 36$ feet with two cellars, in good repair. Fences in fair condition. Will keep 3 cows and 1 horse. Spring water. Fruit orchard of 8 varieties of apples, 3 of pears, cherry and currants. Railroad station, Vergennes, Vt., 1 1/4 miles distant. R. F. D. Telephone. Price, $\$ 5000$ cash. N. J. Renaud, Agent, Vergennes, Vermont.

\section{Vergennes}

Farm of 100 acres, one-half in Vergennes and one-half in Ferrisburg. Pasture, 45; suitable for cultivation, 100. 3 barns, $50 \times 40$ each, in good repair. Fences in good condition. 100 ton silo. Will keep 22 cows and 4 horses. City water and natural springs. This is in a word a city farm, highly cultivated, close to market and station. Railroad station, Vergennes, vt., $1 / 8$ mile distant. R. F. D. Telephone. Price, $\$ 10,000$ or $\$ 9000$ cash down. Louis Renaud, Vergennes, Vt.

\section{Vergennes}

One-half acre lot with two houses, horse barn and metal garage. Cottage, $24 \times 31$; L, $13 \times 16,8$ rooms; in good repair. Barn $35 \times 37$; in good repair. City supply of water. Railroad station, and post-office, Vergennes, Vt., $3 / 4$ mile distant. This is a fine location for a summer home, with all the conveniences of the city. In the most attractive part of Vermont, with beautiful drives and good boating, being at the head of navigation on Otter Creek connecting with Lake Champlain. Price, $\$ 7,000$; cash $\$ 2,500$; balance on easy terms. Address A. D. Willard, Vergennes, Vt.

\section{Waltham}

55 acre farm, pasture, 15; woodland, 4; other acreage, 35; suitable for cultivation, 35. Estimated market value of wood and timber, $\$ 200$. 14 room house, $27 \times 32$ feet, with $\mathrm{L}, 16 \times 30$ feet, in good repair. Barn, $50 \times 100$ feet. Fences in fair repair. Will keep 10 cows and 3 horses. Wells and ponds furnish water. Fruit orchard of 150 pear, 500 plum, 50 cherry and 150 apples trees. Beautiful summer home nicely situated viewing Lake Champlain, the Adirondack and Green Mountains. 1/4 mile from the city limits. Railroad station, Vergennes, Vt., $1 \frac{1 / 4}{4}$ miles distant. R. F. D. Telephone. Price, $\$ 5000$ cash. S. H. Burroughs, Admr., Vergennes, Vermont.

\section{BENNINGTON COUNTY.}

\section{Bennington.}

Farm of 243 acres; pasture, 50; woodland, 75; other acreage, 118; suitable for cultivation, 100. Estimated market value of wood 
and timber, $\$ 2,000$. House, $26 \times 36 ; \mathrm{L}, 16 \times 24 ; 10$ rooms in good repair. Fences in good condition. Farm will keep 10 cows, 3 horses. Good running water to house and barns. Orchard of 300 apple, 25 plum, 10 cherry trees and 75 currant bushes. Railroad station, North Pownal, 3 miles distant. R. F. D., and telephone. This farm is located on the southern slope of Mt. Anthony. A pleasant location for a summer home, and on account of its sheltered position is well adapted to poultry raising and fruit growing. 3 miles from the B. \& M. R. R., and within 4 hours of Boston or New York. Price $\$ 3,000$. Address Martin Peckham, 110 Scott St., Bennington, Vt.

\section{Dorset.}

Farm of 130 acres; pasture, 60 ; woodland, 40 ; suitable for cultivation, 30. "Ethan Allen House"-built about 1775-used at present for storing hay. A magnificent spring about two rods from house. Railroad Station, M. D. \& G. R. R., 1/2 mile distant. R. F. D. and telephone. This property joins the "Norcross West Marble Quarries". It has large deposits of white and gray marble which crop out in several places, and add much to its value. Price, $\$ 5,000$; cash, $\$ 2,500$; balance on interest at 5 per cent. Address IV. J. Holley, Dorset Vt.

\section{Dorset.}

Farm of 4 acres. House, $22 \frac{1 / 2}{2} 32 \frac{1}{2} ;$ L, $20 \times 17 \frac{1}{2} ; 8$ large rooms, besides pantry, hall and woodshed, all in good lepair. Barn, $40 \times 26$, newly built. Fences in good condition. 4 ton silo. Supplied with village water. Orchard of 2 pear, 16 apple trees and berry bushes. Railroad station, Rutland R. R., at Manchester, 7 miles distant. Post office, Dorset. R. F. D. and telephone. This is a nice village home on the edge of Dorset village. School, post office and churches nearby. Club house and golf links, 5 miles distant. About 20 rods front, with row of large maples on fence line. Price, $\$ 3,500$; cash, $\$ 1,500$. Balance on interest at 5 per cent.

\section{East Dor'set.}

Farm of 800 acres; pasture, 40 ; woodland, 700 ; suitable for cultivation, 60. Estimated market value of wood and timber, $\$ 5,000$. House, $24 \times 30$; L, $16 \times 20$; 7 rooms in fair repair. Barn, $24 \times 50$, in good repair. Fences in good condition. 40 ton silo. Supplied with water from Otter Creek. Orchard of 50 apple, 5 pear and crab apple trees. Railroad Station, E. Dorset, Vt., $1 \frac{1 / 2}{2}$ miles distant. Situated on head waters of Ottel Creek. Timber, white and yellow birch, ash, oak and manle. Also a good sugar orchard. Price, $\$ 6,000$; cash $\$ 2,000$. Balance on interest at 5 per cent. Address G. F. Griffith, East Dorset, Vt.

\section{North Dorset.}

Farm of 72 acres; pasture, 28; woodland, 20 ; suitable for cultivation, 24. House, 21 x 27; L, 14 x 22; with milk room and shed chamber. Barn, 33 x 42 ; in fine repair. Fences in good condition. Wagon shed attached to barn, $14 \times 28$, slated. Farm will krep 10 cows and 1 horse. Orchard of 150 apples, 12 plum, 2 pear and 4 cherry trees. Railroad station, North Dorset, Vt., 40 rods distant. R. F. D. and telephone. This farm is on the main line of travel from Bennington to Manchester to Rutland and Burlington. Is practically a village property, only two minutes' walk from station. Change of business of owner makes it necessary to move from East Dorset. Price, $\$ 2,500$; cash, $\$ 1,500$. Balance on interest at 4 per cent. Address Ernest L. Whitney, North Dorset, Vt.

\section{North Dorset.}

Farm of 70 acres; pasture, 20; woodland, 25; suitable for cultivation, 25. Estimated market value of wood and timber, $\$ 400$. House, 24 
x 26; 7 rooms in good repair. Barn, 36 x 44. Fences in fair condition. 25 ton silo. Farm will keep five cows and two horses. Good water supply. Orchard of 30 trees, Baldwin, Wealthy, Greening, Spitzenberg, Northern. 3 hen houses, one is $12 \times 36$, and the other two are $10 \times 12$. Currants, plums and berries. Good running stream of water and best spring in the state. Price, $\$ 1,000$; cash, $\$ 600$; balance on interest at 5 per cent.

\section{North Dorset.}

Farm of 77 acres. Spring water. Railroad station, North Dorset, 5 minutes' walk. R. F. D., telephone. This land is a high, beautifully wooded piece, overlooking Lake Emerald. A good spring. Near a level, cleared plateau. Suitable for fine summer home. Grounds could be laid out and beautified at small cost. Price, $\$ 1,800$. Address, Esther A. Calahan, Manchester Center, Vt.

\section{Manchester.}

Farm of 8 acres, pasture, 2 ; suitable for cultivation, 8 . House, $26 x$ 32 ; L, $18 \times 20$; 11 rooms all new. Barn, $24 \times 48$. Fences in good conaition. Will keep 2 cows and 2 horses. Water in house and barn. Fruit orchard of 15 trees. R. F. D. and telephone. Price, $\$ 4,500$; cash, $\$ 1,500$; balance on interest at 5 per cent. 50 rods from the house is a 70 acre pasture and sugar orchard; 1,000 trees and 1100 tin buckets. Sugar house, $24 \times 30$. Evaporator and storage tanks. Buildings nearly new; beautiful lawn and shade trees. Fine scenery, good market. 1/2 mile from Equinox House, church, court house and village school. Will sell for $\$ 1,500$. Address M. J. Covey, Manchester, Vt.

\section{Manchester.}

Farm of 100 acres. Spring water. Railroad station, Manchester, Vt., $1 \frac{1}{2}$ miles distant. R. F. D., and telephone. Bungalow and camp sites in sizes to suit purchasers. The Battenkill and a mountain stream flow through the property. Very fine views of all the surrounding mountains, including Mts. Equinox and Aeolus. Easily reached over good roaùs. Farm products can be obtained from property farm house cr other farms near. Hunting and fishing. $2 \frac{1}{2}$ miles from the famous Ekwanok Golf Club and Equinox House. Entire property is very picturesque and contains many ideal sites. Address Miss Adeline E. Bock, Manchester Depot, Vt.

\section{Manchester Center}

Farm of about 100 acres; pasture, 40; woodland, 10; other acreage, 50. House, $28 \times 38 ; \mathrm{L}, 16 \times 28 ; 8$ rooms in good repair. 4 barns, 28 $\mathrm{x} 40 ; 20 \times 42 ; 28 \times 36$; and $30 \times 40$; in good repair. Fences in good condition, 50 ton silo. Farm will keep 20 to 25 cows and 3 to 4 horses. Water runs from spring to house and yard. Orchard of about 20 different fruits. Railroad station, Manchester Depot, $1 \frac{1 / 4}{4}$ miles. R. F. D. and telephone. This farm is on the main road from Manchester to Rutland. The country is thickly settled. The soil is heavy loam and very productive. Fine sugar orchard but small. If sold soon, will take $\$ 6,000$ for farm and stock of tools. Can arrange to make the payments satisfactory to buyer. Price, $\$ 5,000$; cash $\$ 3,000$. Address J. H. Dimond, Manchester, Center, Vt.

\section{Per'u.}

Farm of 20 acres; all suitable for cultivation. House, $28 \times 36 ; 8$ rooms in good repair. Barn, $30 \times 36$; in good repair. Fences in fair condition. 20 ton silo. Farm will keep 2 cows and 1 horse. Fine water. Small apple orchard. Railroad station, Manchester, 9 miles distant. R. F.. D. and telephone. Beautiful location, fine view from house. On automobile route from New York to White Mountains. Town growing in popularity as a summer resort. Real estate doubled in value in a few years. 
Fine place for a summer home. Price $\$ 1,500$; cash, $\$ 1,000$; balance on interest at 5 per cent. Address W. H. Burroughs, Hillcrest, Peru, Vt.

\section{Shaftsbury}

Two acres of land, soil very rich. Store, 2 stories, slate roof, $26 \mathrm{x}$ 36 feet, with cellar under whole, L, $25 \times 34$ feet; six rooms on second floor, water piped in store and second floor, condition good. House $1 \frac{1}{2}$ stories, shingled roof, $30 \times 30$ feet, with cellar; L, $15 \times 20$ feet; nine large rooms. Barn, 24 x 28 feet with wagon shed attached, $13 \times 24$. Orchard of 33 apple (12 varieties) 7 pear and 2 grapevines. The business has been profitable for thirty years without any poor years. Stock carried, about $\$ 2500$., consisting of general merchandise of staple goods. Sales for past six years have averaged over $\$ 250$ weekly. Nearest competitor 5 miles. Station, express office, church and school nearby. New England telephone and W. U. telegraph. Price for real estate, $\$ 3,000$ for quick sale. Portion of purchase price may remain on mortgage. Stock will be sold at reasonable prices or closed out. Address F. B. Randall, Shaftsbury, Vermont.

\section{Bondville-Town of Winhall}

60 acre farm, on main travelled road between two villages, one-half mile to each. Level mowing, no rocks. Good eight room house. Good barn; never failing running water in house and barn yard. Cuts 15 tons of hay. Mowing land in high state of cultivation. Cement stable in barn for cows and calves. Well fenced pastures. Beautiful scenery; good road. Creamery $4 \frac{1}{2}$ miles distant. Churches, school houses and stores, one-half mile. House is surrounded by maple trees. West river borders the farm on one side. Will keep 6 cows, 2 steers, 2 heifers and two horses. A good working farm or a good summer home. Mail daily. Price, $\$ 1,000$. Address Elton E. Ladd, Bondville, Vt.

\section{I'inhall}

Farm of 300 acres; pasture, 30 ; woodland, 200 ; suitable for cultivation, 70. Estimated market value of wood and timber, $\$ 2000$-wood $\$ 5$ per cord. 8 room house, $36 \times 26$; L, $22 \times 14$, in good repair. Barn, $30 \times 40$; in good repair. Fences in good condition. 25 ton silo. Farm will keep 10 cows and one pair of horses. 2 springs furnish water. Good orchard of 200 trees. Railroad station, South Londonderry, 6 miles distant. R. F. D. In fine location. Good roads any time of year. Fine market for butter, cream and milk. Address John Douglas, R. F. D., No. 1, South Londonderry, Vt. Box 48.

\section{CALEDONIA COUNTY}

\section{Passumpsic-Town of Barnet}

Wood lot of 25 acres, estimated to contain over 400,000 feet of timber. Within three miles of station, all down grade. Price, $\$ 3,250$. Address AIfred Morse, Passumpsic, Vt.

\section{Burke}

Farm of $1271 / 2$ acres; pasture, $771 / 2$, woodland, 20 ; other acreage, 50. Estimated value of wood and timber, $\$ 1,000$. House, $40 \times 30 ; \$$ rooms in good repair. Barn, $40 \times 50$; in good repair. Fences in good condition. 100 ton silo. Farm will keep 30 cows and 3 horses. Good water supply. Orchard of 25 trees--Duchess, Peach, Winter, Yellow Transparent and native. Railroad station, West Burke, $2 \frac{1}{2}$ miles distant. This farm is in a good state of cultivation and is in a good locality. Will sell farm with stock and tools if so desired. Price, $\$ 3,000$. 


\section{Burke}

2 story building, $25 \times 30$ feet, recently clapboarded and shingled, with shed on front side, $15 \times 25$ feet. Also ice house and cooling room on side of building $18 \times 20$ feet together with about $1 / 2$ acre of land and mill privilege. Railroad station, West Burke, $1 \frac{1}{2}$ miles; Post Office Burke, $1 / 4$ mile. This property has been used for a creamery and I have a creamery outfit that I would like to sell at reasonable price. Price, $\$ 500 ; \$ 100$ cash, balance on interest at 5 per cent. Address John Perrault, Box 74, Lyndonville, Vermont.

\section{Burke}

Farm of 82 acres; pasture, about 40 ; woodland, 22; other acreage, 20 ; suitable for cultivation, 50. Estimated market value of wood and timber, $\$ 700$ besides sugar trees. 9 room house, $40 \times 25 ; \mathrm{L}, 40 \times 30$; in fair condition. Two barns, one $28 \times 38$; the other $40 \times 46$; in good repair. Fences in good condition. 60 ton silo. Farm will keep 8 cows and 2 horses. Water running at house and barn. Orchard of 25 apple and 4 plum trees. 600 sugar trees, 550 rigged with good buckets and covers. Railroad station, West Burke, 2 miles distant. R. F. D. and telephone. About 4 miles from Willoughby Lake, a very pretty western view. Aiso 20 acres of tillage land in good condition about 4 miles from farm. Price, $\$ 1,800$, cash preferred. Address Hiram H. Moulton, West Burke, Vt.

\section{Danville}

Farm of 10 acres, all suitable for cultivation. House, $28 \times 32$; L, $16 \times 36 ; 11$ rooms in good repair. Barn, $24 \times 36$; in good repair. Fences in good condition. Supplied with village water. Situated in the village and on the main street. An ideal location for summer boarders. All modern improvements. Streets electric lighted. Railroad station, Danville, Vt., 3/4 mile distant. Address M. M. Stocker, Danville, Vt.

\section{West Danville}

Farm of 110 acres; pasture, 40; woodland, 25; other acreage, 45; suitable for cultivation, 45. Estimated market value of wood and timber, $\$ 2,000$. House, $32 \times 28$; L, $36 \times 24 ; 16$ rooms in extra good condition. Barn, 65 x 40 , in good condition. New fences. Farm will keep 14 cows and a team of horses. Extra nice spring water. Small apple orchard. House has all modern improvements. Always full of summer boarders from $\$ 7$ to $\$ 10$ per week. Cottage lots enough to sell to pay for one-half of farm. One of the best money making farms in Caledonia County. Easy to carry on. Buildings consist of house and ell all newly shingled. Two story barn, hen house, carriage house, ice house filled. Band stand, boat house and a rowboat landing. Can furnish picture and reading matter of the place and its surroundings. A lovely place for a country home, or a big money making proposition for someone with a little money to get rich. Cause of selling, poor health. Address Lakeside House, West Danville, $\mathrm{Vt}$.

\section{Groton}

210 acre farm; $1 / 2$ mile from railroad station, village graded school, churches and stores; land in high state of cultivation; fine trout brook; one of the best pastures in New England; sugar orchard 700 trees; large amount of wood and lumber; fruit for home use. Modern house, 12 rooms. Hot and cold water, bath, furnace heat. Barn, $100 \times 44$; basement, engine room, silo, 40 tieups, 6 horse stalls, 1 box. Running water in house and barn; electric lights. Poultry house for 600 fowl. R. F. D. and telephone. Address F. M. Weld, Groton, Vt. 


\section{Hardwick}

Farm of 150 acres; pasture, 50; woodland, 60 ; suitable for cultivation, 40. Estimated market value of wood and timber, $\$ 1,000$. House, $32 \times 40$; L, $28 \times 50 ; 9$ rooms in good repair. Parn, $40 \times 65$; in good repair. Fences in good condition. 100 ton silo. Farm will keel) 20 cows and three horses. Running water in house and barn. Small apple orchard. Sugar orchard 200 trees. Hen house, 120 feet long. Horse barn, basement for hogs and wagon house. 25 acres of land in one meadow, the rest smooth and nice to work. Furnace in house. Address E. H. Nelson, Hardwick, Vt.

\section{East Hardwick}

Farm of 3 acres, suitable for cultivation. House, $50 \times 30 ; \mathrm{L}, 25 \times 30$; rooms 13, in good repair. 2 barns, one $30 \times 40$ and the other $20 \times 20$, in good repair. Fences in good condition. 20 ton silo. Farm will keep 1 cow and two horses. Spring running water at barn and house. Small fruit orchard. R. F. D. and telephone. Piazza front of ell; covered driveway at end of house. Shade trees in front. Price $\$ 3,700$; one-half cash; balance on interest at 5 per cent. F. V. Hassam's Place.

\section{Lyndon}

Village property: Two tenement block and store; $40 \times 60 ; 16$ rooms in good repair. Barn, $20 \times 30$; in good repair with good carriage shed attached. Railroad station, Lyndon, $1 / 4$ mile distant. Telephone. The above described property is in a very desirable village. Electric lights and precinct water in block. Rents readily for $\$ 25$ per month. Price, $\$ 1200$; part cash, balance on interest at 6 per cent. Address Willis A. Bradshaw, Concord, Vt.

\section{Newark}

Woodlot of 500 acres; 7 miles from railroad station, viz: West Burke. This lot has some of the finest old growth birch in the state. Two million feet of hard and soft wood. Prices given to responsible parties. Address Harris D. Packer, Newark, Vt.

\section{Ryegate}

Farm of 6 acres; pasture, 4; suitable for cultivation, 2. House, $25 \times 30$; 11 rooms in good repair. Barn, $30 \times 20$; in good repair. Fences in good condition. Farm will keep 2 cows and 1 horse. Connected with the above is a good country store and the house described is annexed. This is one of the best farming communities in the state. Running water and water main included, which supplies three other houses. Small orchard of 15 apples trees. Railroad station, East Ryegate, $21 / 2$ miles distant. Price, $\$ 2,000$ cash. Address W. D. White, Ryegate, Vt.

\section{East Ryegate}

Farm of 90 acres; pasture, 40 ; woodland, 22 ; suitable for cultivation, 28. Estimated market value of wood and timber, $\$ 600$. House, $38 \times 30$; L, $38 \times 34 ; 8$ rooms in good repair. New barn, $76 \times 44$; in good repair. Fences in good condition. 80 ton silo. Farm will keep 18 cows and 2 horses. Spring water. Small apple orchard. Horse barn, $28 \times 30$; hen house, $40 \times 28$. R. F. D. and telephone. The best located farm, everything considered, in Caledonia County. Would make an ideal home for a couple desiring a small farm. The tillage is perfectly smooth and very easily carried on. Is located on the river road and on the line of the Boston \& Maine Railroad. Is only 2 miles from two stations, gristmill, creamery, stores, academy, etc. Has running water to house, horse barn and big barn. Railroad station, McIndoe Falls, 2 miles distant. Price, $\$ 3,000$; cash, $\$ 1,600$; balance on interest at 5 per cent. Address Linwood F. Whitehill, R. F. D., No. 1. East Ryegate, Vt. 


\section{St. Johnsbury Center}

$3 / 4$ acre land and 7 room cottage house, in good repair, just a few steps from the station. Good well water. Small barn in good repair; will stable two horses or one horse and one cow. Pig pen and wagon shed. Also a garden plot. An exceptionally pleasant place in summer. On the main street between two large towns. Price, $\$ 1,600$ cash. Addrezs Mrs. Rebecca Harriman, St. Johnsbury Center, Vt.

\section{St. Johnsbury Center}

Village property; $1 \frac{1}{2}$ acres of land suitable for cultivation. 10 room house, $27 \times 33$, with piazza, $27 \times 5 \frac{1}{2} ; \mathrm{L}, 18 \times 34$; also shed, all in good repair. Barn, $27 \times 42$, in good repair. 1 ton silo. Spring water both house and barn. Large shade trees on lawn. Good vegetable garden and small fruits. About 8 minutes' walk from graded schools or 5 minutes' ride by steam cars to St. Johnsbury Academy, one of the best preparatory schools in New England. On main automobile drive. For sale to settle an estate. Price, $\$ 2,000$; one-half cash. Address Mrs. C. W. Farr, St. Johusbury Center, Vt.

150 acre farm; pasture, 85; woodland, 25; suitable for cultivation, 40. Estimated market value of wood and timber, $\$ 800$. House, $26 \times 30$; $\mathrm{L}, 24 \times 36 ; 11$ rooms in first class repair. Barn, $44 \times 60$; in fine repair. Fences in good condition. 60 ton silo. Farm will keep 12 cows and 3 horses. Spring water. Orchard of 60 apple trees-Bethel, Peach and Duchess. Railroad station, $81 / 2$ miles distant. One of the finest locations on automobile road leading from St. Johnsbury to Barton. Never failing spring water to house and barn. Sugar orchard of 500 trees. Only reason for selling is because of poor health of the owner. Price, $\$ 3,200$; cash $\$ 1,200$; balance on interest at 5 per cent. Address J. S. Chesley, Sheffield, $\mathrm{Vt}$.

\section{Sheffield}

Farm of 95 acres; pasture, 25 ; woodland, 45 ; suitable for cultivation, 25. Estimated market value of wood and timber, $\$ 800$. House, $36 \times 30$; $\mathrm{L}, 35 \times 25 ; 12$ rooms in first class condition. Barn, $40 \times 35$; in fine repair. Fences in good condition. 40 ton silo. Farm will keep 12 cows and 3 horses. Spring water. Small fruit orchard. House strictly modern. Price $\$ 4000$; cash, $\$ 1000$; balance on interest at 5 per cent. S. A. Jones, M. D., Sheffield, Vt.

\section{Sutton}

Farm of 145 acres; pasture, 50; suitable for cultivation, 45 . Estimated market value of wood and timber, $\$ 1,500$. 7 room house with $\mathrm{L}, 40 \mathrm{x}$ 20 , in fair condition. Three barns, $40 \times 30,30 \times 20,40 \times 30$. Fences in fair condition. 40 ton silo. Will keep 18 cows and 3 horses. Spring water. Fruit orchard-40 trees. Nice view. Pretty place. Railroad station, Sutton, Vt., 2 miles distant. R. F. D. and telephone next door. Price, $\$ 2,000$; cash, $\$ 900$; balance on interest at 6 per cent. Address W. Hamilton, Sutton, Vt.

\section{Sutton}

Farm of 135 acres; pasture, 75; woodland, 30. Estimated value of wood and timber, $\$ 1,200$. House, $25 \times 25 ; \mathrm{L}, 25 \times 15 ; 8$ rooms in good repair. 2 barns, $24 \times 30,28 \times 30$, in good repair. Fences in good condition. Will keep 10 cows and 2 horses. Orchard of 15 trees. Good farm, lies level and free from stones. Good sugar orchard, well equipped. R. F. D. and telephone. Price, $\$ 2,500$; cash, $\$ 1,300$; balance on interest at 5 per cent.

Farm of 125 acres; pasture, 40; woodland, 40; other acreage, 55; 
Estimated market value of wood and timber, $\$ 700$. House, $30 \times 28$; L, $30 \times 18$; 11 rooms in good repair. Barn, $30 \times 36$; in good condition. Fences in good condition. 20 ton silo. Will keep 15 cows, and 3 horses. Running water in house and barn. Apple orchard. Small sugar orchard. Railroad station, Greensboro, 3 miles distant. R. F. D. and telephone. Price, $\$ 2,000 ; \$ 1,000$ cash; balance on interest at 6 per cent. Address D. IV. Stevens, Hardwick, Vt.

\section{CHITTENDEN COUNTY}

\section{Charlotte}

Three excellent dairy farms, situated in Charlotte, Vt., also village property for sale; prices reasonable. Address IVm. H. Boardman, Charlotte, Vt.

\section{Charlotte}

Farm of 200 acres; pasture, 95; woodland, 25; other acreage, 80 ; suitable for cultivation, 140. Estimated market value of wood and timber, $\$ 800$; sugar orchard of 300 trees, and sugar house. Barn, $50 \mathrm{x} 30$ feet, also three other barns suitable for keeping stock in and a granary. House, $30 \times 25$ feet; L, $45 \times 22$ feet, second wing, $60 \times 20$ feet; eighteen rooms. House in good repair; barns and fences in good condition. Will keep 25 cows and 4 horses; running water in every field. Orchard of 75 trees, consisting of Greenings, Northern Spy and Fameuse. Farm situated on road from Hinesburgh to Charlotte; 6 miles from Lake Champlain, and 12 mile from Burlington. R. F. D. and telephone. Price, $\$ 7000 ; \$ 2000$ cash; balance on interest at jo per cent. Address E. Hudson Converse, Charlotte, Vt.

\section{Colchester}

Place of 12 acres, all suitable for cultivation, situated in the village of Winooski, Vt. House, $34 \times 25$ feet; L, $22 \times 32$ feet; 18 rooms. House has all modern conveniences and is in the best of repair. Barn, $26 \times 32$ feet, in good repair. Fences in good condition. City water. Orchard of about 50 old trees, and a few young trees, plums, pears, etc. Distance from railroad station and post office, one-third of a mile. Telephone. There is a house on the place that rents for ten dollais per month. A number of lots can be sold. Price, $\$ 10,000 ; \$ 3,000$ to $\$ 5,000$ cash; balance on interest at 5 per cent. Address, E. Barton Whitney, Winooski, Vt.

\section{Colchester}

Woodlot of 550 acres; approximately 50 acres of coppice thickets, about ten years old; 250 acres of 20 year old oak, maple and birch; 250 acres of 40 to 60 years old, composed chiefly of poplar, paper birch, hemlock, white pine and oak. Open patches covered with wild fruits of different kinds. Several acres of grass lands. The lot already frequented by deer, grouse and a few trout in the brooks that flow through the land. Enough adjacent land of similar nature could be purchased to make 1000 acres in a single block. Good building sites on the lot, and ideal ones on adjacent areas, giving unobstructed views of Mt. Mansfield, Camel's Hump and other points of the Green Mountains on the east, of Lake Champlain and the Adirondacks on the west. A portion of the boundary lines of this lot run within a hundred rods of the IVinooski River at points which will soon be an artificial lake caused by large dam for development of electric power. The lot is 9 miles from Burlington from which is a 20 minute car service to Essex Junction, which is one mile from the edge of the lot. Can be approached from three stations on the Central Vermont Railway, none of which are over two miles away, the principal one being Essex Junction, which is $61 / 2$ hours from Boston and 9 hours from New ' 10 rk City. Price, $\$ 5,000$. Address C. D. Howe, Morrisville, Vt. 


\section{Huntington}

"The Camel's Hump Fruit Farm" in Huntington. Farm of 290 acres; house $26 \times 36$ feet, L $20 \times 30$ feet; barn $30 \times 90$ feet, with cellar; fair repair. Will keep 25 cows and three horses; never failing water; orchard of 240 trees, Northern Spy, McIntosh, Snow, Bethel, etc., sugar orchard. This is a very productive, easily tilled farm. Address J. E. Andrews, Essex Junction, Vt.

\section{Jericho}

Farm of 160 acres; pasture 90 acres; woodland, 20 acres; other acreage, 50 acres; suitable for cultivation, 100 acres; estimated market value of wood and timber, $\$ 1000$; house, $30 \times 60$; wood shed $15 \times 30$ feet; twelve rooms; house in good repair; barn $96 \times 32$ feet; cellar; in good repair; fences in good condition; silo of 125 tons capacity. Will keep 30 cows and 4 horses. Running water; orchard consisting of a few apple and plum trees. Telephone and R. F. D. Sugar orchard in which 700 buckets are used. 1/4 of a mile from high school, store, post office and church. Railroad station, Jericho, Vt., 3 miles distant. Price, $\$ 8000$; cash, $\$ 5000$; balance on interest at 5 per cent. Address E. J. Ransom, Jericho Center, Vermont.

\section{Jericho}

Farm of 154 acres: 102 acres in home farm, 52 acres woodland; 50 acres pasture, the principal part of which is plowable land; 52 acres of cultivated land; estimated market value of wood and timber, $\$ 500$; house of brick, $22 \times 30$ feet; $L$ of wood $43 \times 20$ feet; 10 rooms; in good repair; ice house clapboarded and painted; barn $70 \times 40$ feet; cellar; in good repair; good manure barn; fences in good condition; will keep 14 cows, 2 horses; water at house and barn; 70 good fruit trees; a very pretty house with large porch; nice view of Mt. Mansfield; large lawn; 3 miles to Jericho Center where there is a good graded and high school; railroad station $4 \frac{1}{2}$ miles; post office, church, school and store, 1 mile. R. F. D.; telephone if desired. Price $\$ 3,500$; one half cash, balance at 6 per cent. Old age only reason for selling. Address P. J. Hurson, Jericho, Vt.

\section{Milton}

No. of acres, 6, all suitable for cultivation. House $20 \times 24$ feet; L, $10 \times 12$ feet; 7 rooms; in good repair; barn $18 \times 26$ feet; in good repair; fences in good condition; water, well, pump in house; several varieties of small fruit trees; railroad station and post office, Milton, Vt.; distant $2 \frac{1}{4}$ and 2 miles, respectively; level sandy loam, well suited for raising strawberries and small fruits; good cellar under main part of house; R. F. D.; telephone, if desired. Price, $\$ 500 ; \$ 250$ cash, balance at 5 per cent interest. Address, Mrs. Lizzie Weston, Cambridge, Vt.

\section{South Burlington}

Farm of about 90 acres, known as the Doctor Sparhawk farm, $21 / 2$ miles from Burlington, just off from the Williston road; comfortable house and barn and large hen house; excellent opportunity for poultry raising and market gardening. Price $\$ 50$ per acre. Address Charles King, Burlington, Vt., R. F. D., or J. W. Page, Burlington. Vermort.

\section{Underhill Center}

Hotel with 75 acres of land; pasture, 20 acres; woodland, 35 acres; other acreage, 20 acres; suitable for cultivation, 20 acres; estimated market value of wood and timber, $\$ 1000$. Hotel has 22 rooms; in good repair; barns in fair repair; water; railroad station, Underhill, Vermont, distance, $2 \frac{1}{2}$ miles; telephone; delightfully situated for summer guests. Beautiful scenery; elegant mountain drives, trout fishing, nice roads. Price, $\$ 4000$. Terms, easy. Address Fred H. Prouty, Marshfield, Vt. 


\section{Underhill Center}

Underhill Mill, located on the C. V. tracks near the depot; all grain unloaded from cars to the mill, power shovel and elevator, etc.; equipped with up-to-date machinery; power is 75 horse power gas producer, costing about $\$ 1.25$ per day to run; mill has ample storage for corn and oats overhead and storage house $45 \times 30$ feet for sack grain annexed to main mill which is $60 \times 40-30$ feet posted; heated by furnace installed the past winter; doing business of $\$ 40,000$ to $\$ 50,000$ each year. Price $\$ 10,000$ for mill and all appliances. Address J. E. Foster, Underhill, Vt.

\section{Westford}

Wood lot of 60 acres; located in eastern part of Westford, upon which there is a large amount of hard wood, estimated to be 1000 cords; lot easy of access. Would be pleased to sell the wood standing. Address, R. B. Field, Jericho, Vermont.

\section{Westford}

Farm of 286 acres; pasture, woodland and suitable for cultivation, about equal; house, $30 \times 42$ feet; L, $26 \times 50$ feet; 15 rooms; in good repair 3 barns with cellar; good repair; fences in good condition; running water; silo, 150 tons capacity; will keep 50 cows and 6 horses; small orchard; will keep young stock; railroad station, Essex Center, 1 mile distant; R. F. D.; telephone; buildings in center of farm. Price $\$ 12,000 ; \$ 6000$ balance on interest at 5 per cent.

\section{Westford}

Farm of 312 acres; pasture 260 ; other acreage 52; suitable for cultivation, 52; house $38 \times 28$ feet; 9 rooms. Horse barn $26 \times 24$ feet; 1 cow barn $44 \times 33$ feet; another, $39 \times 28$ feet; wagon house, $20 \times 18$ feet. There are now on the place 17 cows, 5 yearlings, 5 calves, 2 horses; orchard of 7 plum trees and several apple trees; also a sugar orchard of about 1000 trees, equipped with sugar utensils; railroad station, Cloverdale, distant $2 \frac{1}{2}$ miles; telephone. Price $\$ 6000 ; \$ 1,500$ cash; balance on interest at 6 per cent. Address Hiram Blackmer, Westford, Vermont.

\section{Williston}

Farm of 13 acres, pasture, 3 acres; suitable for cultivation 10 acres; house, $26 \times 31$ feet; L, $15 \times 24$ feet; no. of rooms, 9; in good repair; barn, $30 \times 40$; fences in fair condition; will keep 3 cows and 2 horses; water; orchard of 16 apple and 15 plum trees, 2 grape vines; water in cellar in house; well near barn; good hen house $10 \times 40$ feet; house has a veranda; railroad station, North Williston, distant $2 \frac{1}{2} \mathrm{miles}$; post office Williston, $1 / 2$ mile. R. F. D. and telephone. Price $\$ 1,400$. Address C. G. Austin, IVilliston, Vermont.

\section{ESSEX COUNTY}

\section{Concoid}

Farm of 410 acres; pasture, 285; woodland, 125; other acreage, 125. Estimated value of wood and timber, $\$ 4000$ to $\$ 5000$. House, $36 \times 40$; L, 24x30; 21 rooms in good repair. Barn, $36 \times 80$; in good repair. Fences in good condition. 200 ton silo. Will keep 60 to 100 cows and 4 to 6 horses. Running spring water. Orchard of 50 apple trees. Railroad station, Concord, Vt., 2 miles distant. R. F. D., and telephone. Write for price and further particulars. Part cash and part to remain on mortgage at 5 per cent. Address Willis A. Bradshaw, Concord, Vt.

\section{FRANILLIN COUNTY}

\section{South Bakersfield}

Farm of 110 acres; pasture, 35; woodland, 50; other acreage, 25; 
suitable for cultivation, 35; estimated market value of wood and timber, $\$ 1200$ to $\$ 1500$. House, $26 \times 30 ; 8$ rooms in good repair. 2 barns, $30 \times 40 ; 24 \times 30$; in excellent repair. Fences in good condition. Will keep 10 cows and 2 horses. Excellent, never failing, spring water. Good apple orchard. Sugar orchard of 1000 trees, 900 newly equipped. New sugar house. Railroad station, E. Fletcher, 4 miles distant. R. F. D. and telephone. Price, $\$ 3,250$; cash, $\$ 1,600$; balance on interest at 5 per cent.

\section{Enosburg Falls}

Farm of 3 acres: pasture, 2; suitable for cultivation, 1. House, $30 \times 36 ; \mathrm{L}, 20 \times 40 ; 12$ rooms in good repair. Railroad station, $1 / 4 \mathrm{mile}$ distant. R. F. D., and telephone. One of the best locations in the village, facing a very pretty little park. Near churches and school. Price, $\$ 3,000$; cash, $\$ 1000$; balance on interest at 5 per cent. Address Henry W. Allen, Enosburg Falls, Vt.

\section{Fairfield}

5 acres of land on the shore of Fairfield Pond. 2 cottages, one $20 \times 10$; the other $28 \times 15 ; 4$ rooms very good repair. This land is known as Birch Point and is surrounded on three sides by water. Dream Lake, as this pond is called, is two and a half miles long and one mile wide. It is well shaded. Fine water, good fishing, bass, perch, etc. Fine shore for bathing. Private road to this point, $1 / 4$ mile. Price, $\$ 1000$; cash, $\$ 200$; balance on interest at 5 per cent. For further information address N. J. Lachance, Fairfield, Vt.

\section{Highgate}

Farm of 175 acres; pasture, 50; woodland, 25; suitable for cultivation, 100 ; estimated market value of wood and timber, $\$ 1,000$. House $24 \times 36 ; \mathrm{L}, 20 \times 30 ; 8$ rooms in good repair. Barn in good repair. Fences in good condition. 100 ton silo. Will keep 30 cows and 4 horses. Good well and spring water. Small orchard. Farm is on nne highway leading from Highgate to St. Albans - 2 miles south of Highgate-4 miles east of Swanton village. Situated in the town of Swanton. Railroad station, Highgate, 2 miles distant. R. F. D., and telephone. Price $\$ 7000$; cash $\$ 3000$; balance on interest at 5 per cent. Address C. $R$. Lyon, Highgate Center, Vt.

\section{Highgate}

Village property. Garden of one-half acre. House, $22 \times 26$; L, $20 \times 20 ; 7$ rooms in good repair. Barn, $26 \times 22$. Well and cistern water. Small apple orchard. Situated in the center of town. Price, $\$ 1,500$; cash, $\$ 1000$; balance on interest at 5 per cent. Address L. F. Pontbriand, Highgate, Vermont.

\section{Highrate}

Village property. Plumbing, tin and bicycle shop with residence over shop. $1 / 4$ acre garden. House, $33 \times 20 ; 4$ rooms in good condition. Barn and fences in good condition. Well water. Located on the principal street in town; has a well established trade. Postoffice and railroad station, Highgate, one-sixth mile. Price, $\$ 1,400$; cash, $\$ 900 ;$ balance on interest at 5 per cent.

\section{Highgate}

Farm of 206 acres; pasture, 100 ; woodland, 20; other acreage, 86; suitable for cultivation, 150 ; Estimated value of wood and timber, $\$ 1,500$. Brick house, $26 \times 32 ; \mathrm{L}, 20 \times 30 ; 15$ rooms in good repair. 2 barns, $25 \times 35 ; 50 \times 70$; also a tenement house in good repair. Fences in good condition. Will keep 30 to 35 cows and 4 horses. Spring water in house and barn. Orchard of 45 apple trees. This farm is very pleasantly 
located on a main road. Maple shade trees. Fine view. Fertile soil. Easily worked. Railroad station, B. \& M., 1/2 mile distant. R. F. D., and telephone. Price, $\$ 5,500$; cash, $\$ 2000$; balance at 5 per cent; stock and tools. Address M. A. Regan, Highgate, Vermont.

\section{Highgate Center}

Farm of 5 acres, suitable for cultivation. House, $20 \times 30 ;$ L, $18 \times 20$; 8 rooms in good repair. Barn, $20 \times 24$; with cellar in good repair. Fences in good condition. 5 ton silo. Will keep one cow and one horse. Good well water. Pleasantly located between Highgate Center and Highgate Springs; $1 \frac{1 / 2}{2}$ miles from Lake Champlain; 1/2 mile from "Carter Hill"; $2 \frac{1}{2}$ miles from Swanton. Would be suitable for poultry 1a.sing. R. F. D. Railroad station, Highgate Center, 2 miles distant. Price, $\$ 600$ cash. Address C. W. Steele, Highgate Center, Vt.

\section{Fast Highgate}

Farm of 110 acres; pasture, 35; woodland, 10 ; other acreage, 65 ; suitable for cultivation, $\delta 0$. Estimated value of wood and timber, $\$ 1000$, consisting of pine, hemlock, oak and maple. Brick house, $26 \times 30 ; \mathrm{L}$, $20 \times 40 ; 14$ rooms in good repair. 2 barns, $40 \times 60 ; 20 \times 30$; in good repair; fences in good condition. Granary; hog house and hennery. Silo, $10 \times 12 \times 20$. Will keep 18 cows and 3 horses. Spring water in house and barn. Fine location. Would make a fine country home. The farm has a good retail trade in butter, eggs, poultry, fruit and vegetables, meat and fish. R. F. D., and telephone. Price, $\$ 3,500$; cash $\$ 1,500$; balance on intelest at 5 per cent. Address M. A. Regan, East Highgate, Vermont.

\section{Sheldon Springs}

Village property. New 8 room-2 story building, $24 \times 30.1$ acre of land suitable for cultivation. Barn, $24 \times 24$, in good repair. Fences, new. Good running water in house. Price, $\$ 2,000$. Address Wallace B. Whiting, Sheldon Springs, Vt.

\section{Swanton}

Lake View Farm. 1000 acres; woodland, 125 ; suitable for cultivation, 875. Estimated value of wood and timber, $\$ 5000$. Fences in good condition. $2-275$ ton silos. Will keep 100 cows and 20 horses. Lake water. Fine orchard of 500 Baldwin; 500 R. D. Greenings and 200 other apple trees. This is one of the farms with the most tillable acres in New England, with $2 \frac{1}{2}$ miles of lake front. 4 farm houses, 16 barns, 2 cow barns, 1 creamery and several other outbuildings, including a fine cottage with auto garage and horse barn. The farm now carries 100 head of cattle, 20 horses and cuts several hundred tons of hay and grain. Railroad station, Central Vermont, $1 \frac{1}{2}$ miles distant. R. F. D., and telephone. Price, $\$ 50,000$; cash, $\$ 20,000$; balance on interest at 6 per cent.

\section{GRAND ISLE COENTY}

\section{Isle La Motte}

20 acre orchard-hotel and quarry property. Pasture, 20 acres, suitable for cultivation, 30 acres. House, $30 \times 40 ; \mathrm{L}, 30 \times 85 ; 16$ rooms in good repair. 2 barns, $26 \times 36 ; 26 \times 72$; granary, $16 \times 20$. Will keep 4 cows and 2 horses. Spring and well water. 1,000 apple and 75 pear trees. Income from orchard for $1912, \$ 1,500$. House closed during 1913. Situated at lower end of loop between Burlington and Plattsburg, N. Y. On International auto road to Montreal. Also a quarry of 15 acres which has been extensively worked in heavy work or for crushed stone for road building. R. F. D., and telephone. Price to be agreed upon. One-third cash; balance on easy terms at 5 per cent. Address H. H. Hill, Isle La Motte, vt. 


\section{North Hero}

Farm of 62 acres, pasture, 52; woodland, 10; balance suitable for summer cottages. The above farm is about half way between Isle La Motte and North Hero. Beautiful site for camps. Situated on the east shore of North Hero and takes in about one-half mile of lake shore. Railroad station, North Hero or Isle La Motte, 3 miles distant. Price, $\$ 350$ per lot. Address P. J. Farrell, North Hero, Vermont.

\section{LAMOILLE COUNTY}

\section{Cambridge}

Farm of $43 / 4$ acres: house, $25 \times 30 ; 5$ rooms, in fair repair. Two barns, $15 \times 20$. Fences in good condition. Land is suitable for raising any crop that grows in this climate. Farm is especially adapted for vegetable or poultry raising or for a summer home. Is situate on high level in plain view of Mount Manstield. 12 apple trees and small fruit. R. R. station and Post Office, Cambridge, 3 miles. R. F. D. Price, $\$ 450 ; \$ 200$ cash; balance at 5 per cent. Address E. H. Linden.

\section{Cambridge}

Farm of $191 / 2$ acres; woodland, 16 ; suitable for cultivation, 3 . Estimated market value of wood and timber, $\$ 1,000$. House, $40 \times 80 ; 12$ rooms, good repair, heated by furnace, bath, hot and cold water. General store combined with house, with stock of $\$ 1,000$. Barn, $25 \times 40$; cellar. Two new hen houses with yards and run. New barn. Farm will keep 1 horse. Spring water. R. R. station and P. O., Cambridge, 3 miles R. F. D. and telephone. Near church and school. Price, $\$ 3,000$. Address L. H. Scott.

\section{Eden}

Farm of 80 acres: pasture, 40 ; woodland, 6 ; other acreage, 10 ; suitable for cultivation, 24. Estimated market value of wood and timber, $\$ 400$. House, $22 \times 30 ; \mathrm{L}, 16 \times 36 ; 9$ rooms, in good repair. Barns, $30 \times$ 40 and $15 \times 28$, in fair repair. Good fences. Will keep 10 cows, 3 horses. Good running spring water at house and barn. Good orchard for family use-apples, pears and plums. R. R. station, Johnson, 9 miles. P. O., Eden, $1 / 2$ mile. Telephone. Has been owned and occupied by present owner for 33 years. Is situated 1/2 mile north of Eden village, on main road to Franklin county. Good neighbors. Schoolhouse on farm. Stock and tools will be sold with farm if desired. Price, $\$ 1,500 ; \$ 500$ cash; balance at 5 per cent. Address A. F. Rogers.

\section{Elmore}

Farm of 100 acres: pasture, 20; woodland, 60 ; suitable for cultivation, 20. Estimated market value of wood and timber, $\$ 2,500$. House, $26 \mathrm{x}$ 36 ; L, $20 \times 30 ; 10$ rooms, in good $\mathrm{A} 1$ repair. Barn, $30 \times 58$, with cellar, nearly new; hay fork. Fences in fair condition. Will cut 30 to 35 tons of hay. Will keep 10 cows, 2 horses. Water piped from spring. 30 apple trees. Railroad station and P. O. at Wolcott, 4 miles. School, saw mill, 1 mile. R. F. D. Price, $\$ 3,800 ; \$ 2,500$ cash; balance at 5 per cent. Address George C. Bryant.

\section{Hyde Park}

155 acres of timber and wood land; every acre easily reached; much soft wood, including spruce; much pulp wood and fine hard wood. Five miles from Morrisville, Vt., on Garfield road. Address L. .M. Darling, Canaan, Vt.

\section{Johnson}

"Elmhurst Farm" of 107 acres: pasture, 67 acres; other acreage, 40. House, $46 \times 26 ; \mathrm{L}, 50 \times 16 ; 10$ rooms, in good repair. Barn, $98 \times 30$, with 
cellar; fair repair. Good fences; silo, 35 ton. Will keep 18 cows, 2 horses. Well and spring water. 2 pear trees, 50 bearing apple trees and more young trees; plums, currants and black cap berries. Good sugar place of 750 trees, equipped. Produces an income of from $\$ 150$ to $\$ 200$ a year. R. R. station, Johnson, $2 \frac{1}{2}$ miles; P. O., Johnson, 2 miles. R. F. D. and telephone. A good, productive farm in good shape; all work can be done with machinery. Situate high and dry with fine view of surrounding valley and hills in the distance. Would make a fine summer residence. Price, including part of stock on the farm and tools, $\$ 4,200 ; \$ 2,700$ cash; balance at 5 per cent. Address N. J. Perry.

\section{Johnson}

Farm of 160 acres: pasture, 65 ; woodland, 30 ; suitable for cultivation, 70. Estimated market value of wood and timber, $\$ 800$. House, $26 \times 30$; $\mathrm{L}, 20 \times 24 ; 10$ rooms; in good repair. Hot and cold water and bath room. Horse barn, 24 × 30 ; good cellar. Barn, $30 \times 40$; concrete stable. Running water in stable; buckets between cows. Running water in yard. Concrete silo, round, $16 \times 30$. No. tons capacity, 120 . Fences and buildings in good condition. Will keep 30 cows and 3 horses. Never failing spring water. Pasture watered by good trout stream running entire length. Apple orchard of 25 trees. 700 maple sugar trees, with modern equipment. Located on State road, 1 mile from Johnson village which has a normal school, graded and high school, 4 churches. R. R. station $1 \frac{1}{2}$ miles. R. F. D. Telephone line crosses back yard. Lamoille river runs straight by on south side. Price, $\$ 5,000 ; \$ 2,500$ cash; balance at 6 per cent.

\section{Johnson}

Farm of 260 acres; pasture, 135 ; woodland, 50; suitable for cultivation, 75. Estimated market value of wood and timber, $\$ 2,000$. Pulp and hard wood. House, $24 \times 36 ; \mathrm{L}, 21 \times 24 ; 7$ rooms down stairs, not very good repair. Barn, $40 \times 80$, cellar; fair repair. Sugar house, shop and wagon shed combined. Will keep 20 cows, 3 horses. Has kept 70 head. Running spring water. Apple orchard of 200 trees, various kinds. Sugar bush of 1,000 trees, equipped; new arch and evaporator. 12 nice, large butternut trees near house. Farm tools, mower, new horse rake, plow, harrow, cultivator, farm wagon, double harness, new sleds, cream separator, 11 cows, 2 heifers, 1 bull. School house, 125 rods. $11 / 2$ miles to normal school and high school, railroad station and P. O. R. F. D. Price, $\$ 5,500$; $\$ 2,000$ cash; balance at 6 per cent. Address D. J. Cummings.

\section{Johnson}

Farm of $112 \frac{1}{2}$ acres: pasture, 50 ; woodland, $12 \frac{1}{2}$; suitable for cultivation, 50 . House, $24 \times 32 ; \mathrm{L}, 24 \times 36 ; 12$ rooms, good repair. Horse barn $22 \times 50$; cellar; good repair. Stable, $501 / 2 \times 55 \frac{1}{2}$. Two silos. No. tons capacity, 120 . Will keep 20 cows, 3 horses. Good fences. Running water from never failing spring. Farm is well located; meadow land, level and easily worked by machinery. The Lamoille river flows past the meadow. Small sugar place. Excellent graded schools, first class high school, also the Johnson Normal School. Three churches in village. R. R. station, 11/4 miles; P. O., 1 mile. R. F. D. Telephone if desired. Price, $\$ 5,800$; $\$ 4,000$ cash; balance at 6 per cent. Address Ernest W. Griswold.

\section{Dorchester Heights, Town of Morristown}

Village residence of 15 acres: pasture, 3; woodland, 3; suitable for cultivation, 9. Nearly new 16 room house, in good repair. Barn, $30 \times 40$; barn, 24x40; cellar; good repair. Hennery, $12 \times 36$; ice house, $10 \times 12$. Buildings could not be rebuilt for $\$ 12,000$. Good fences. Village water. Will keep 3 cows, 2 horses. Young orchard. Situated on a little eminence overlooking the town. One of the finest views in Vermont. A nice place 
for summer boarders. Some very fine building lots. Railroad station and P. O., Morrisville, $1 / 2$ mile. R. F. D. and telephone. Price, $\$ 10,000$; $\$ 5,000$ cash; balance at 5 per cent. Address C. F. Smith.

\section{Morpistown}

"Laporte Dairy Farm" of 250 acres: pasture, 120 ; woodland, 60 ; suitable for cultivation, 70 . Estimated to be $600,000 \mathrm{ft}$. soft wood; considerable hard wood. House, $30 \times 40 ; \mathrm{L}, 50 \times 24 ; 10$ rooms; hot and cold water; bath room; in good repair. Nearly new $\$$ room boarding house. Barn, 110 x 78 , with cellar; in good repair. Can tie 70 cows in one stable, 110 head in all. Fine new hennery, capacity, 1500 fowls. 350 ton siïo. All modern machinery, electric lights and power, milking machines. Good fences. Running water. Two acre orchard. Farm cuts about 200 tons hay. Will keep 70 cows, 5 horses and young stock. Owner keeps about 100 head of all ages, mostly registered Jerseys. Situate on finest auto road in the State. R. R. station and P. O., Morrisville, 3 miles. R. F. D. and telephone. Price, including personal property, $\$ 24,000$; one-third cash; balance at 5 per cent. Address C. F. Smith.

\section{Stowe}

"Clover Dale Farm" of 235 acres: pasture, 100; woodland, 60 ; suitable for cultivation, 75. Estimated market value of wood and timber, $\$ 1,000$. Tillage land level. House, $26 \times 40 ; \mathrm{L}, 40 \times 20 ; 11$ rooms; good repair. Good tenement for hired man. Barn, $100 \times 43$, with cellar; good repair. Horse barn, $38 \times 36$. Fences in fair condition. Silo. No. tons capacity, 100. Will keep 40 cows, 4 horses. Water from never-failing spring. Two orchards, grafts and natural fruit. Sugar orchard, 600 trees. R. R. station and P. O., Stowe, $2 \frac{1}{2}$ miles. R. F. D. and teīephone. Level road to town. Price, including stock, farm, sugar and dairy tools, $\$ 8,500 ; \$ 4,000$ cash; balance at 5 per cent.

\section{Stowe}

"Town Farm" of 150 acres: pasture, 60; woodland, 40 ; other acreage, 50 ; suitable for cultivation, 40 . Estimated market value of wood and timber, $\$ 500$. House, $20 \times 30 ; \mathrm{L}, 15 \times 20 ; 10$ rooms; good repair. Two barns, $30 \times 40$; good repair. Silo. Buildings would cost more than $\$ 5,000$ to rebuild today. Good fences. Will keep 12 cows, 2 horses. Water at house, spring. Orchard of 30 trees. Sugar orchard of 700 trees, equipped with iron arch, evaporator, sugar-off rig, buckets, spouts, holders, etc. Good sugar house. Corn barn. Mower, lake, harrow, etc. R. R. station and P. O., $41 / 2$ miles. R. F. D. Telephone within $1 / 2$ mile. Elegant view of .Mount Mansfield. School, 1/2 mile. Price, $\$ 1,700 ; \$ 700$ cash; balance at 5 per cent. Address H. E. Shaw.

\section{Stowe}

"Adonis Farm" of 150 acres: pasture, 50; woodland, 60 ; other acreage 40 ; suitable for cultivation, 40. Estimated market value of wood and timber, $\$ 1,000$. House, $20 \times 30 ; \mathrm{L}, 15 \times 20$; No. rooms, 10 ; good repair. Barn, $50 \times 100$; cellar; good repair. Good fences. Silo; No. tons capacity, 50. Will keep 20 cows, 2 horses. Orchard of 100 trees. Sugar orchard of 1,000 trees. Good sugar house, tubs, spouts, holders, iron arch, evaporator, sugar-off rig, etc. 15 cows, pair of horses, full line of tools. Grain barn. Land in good condition and easy to till. Good view of Mount Mansfield. R. R. station and P. O., Stowe, $4 \frac{1 / 2}{2}$ miles. School 1/4 mile. R. F. D. Telephone within one-half mile. Price, $\$ 4,000 ; \$ 1,500$ cash; balance at 5 per cent. Address H. E. Shaw. 
40 ; suitable for cultivation, 20. Estimated market value of wood and timber, $\$ 300$. House, $20 \times 30 ; \mathrm{L}, 15 \times 20 ; 10$ rooms; fair repair. Barn, $30 \times 40$; an extra barn in good shape. Fences in fair condition. Silo. No. tons capacity, 40. Will keep 15 cows, 2 horses. Spring water at house. Orchard of 100 trees, good fruit. A good grass farm, near steam mill. Lots of work and chance to cut wood. R. R. station and P. O., Stowe, 6 miles. R. F. D. Price, $\$ 1,200 ; \$ 600$ cash; balance at 5 per cent. Address H. E. Shaw.

\section{Stowe}

"Harris Farm" of 100 acres: pasture, 25; woodland, 50; other acreage, 25 ; suitable for cultivation, 25. Land easy to till; yood for corn or potatoes. Estimated market value of wood and timber, $\$ 700$. Near a saw mill; lots of lumbering. House, $20 \times 30$; L, $15 \times 20$; 10 rooms; fair repair. Barn, $30 \times 40$. Fences in fair condition. Will keel) 6 cows, 2 norses. Spring water at house. Orchard of 50 trees. R. R. station and P.O., Stowe, 6 miles. R. F. D. Telephone within $3 / 4$ mile. Price, $\$ 1,200 ; \$ 600$ cash; balance at 5 per cent. Address H. E. Shav.

\section{Stowe}

"Jelley Farm" of 20 acres: pasture, 5; woodland, 5; other acreage, 10 ; suitable for cultivation, 10 . Estimated market value of wood and timber, $\$ 100$. Near steam saw mill, and work the year around. House, $20 \times 30$; L, $15 \times 20 ; 9$ rooms; fair repair. Barn, $24 \times 30$, with cellar; fair repair. Fences in fair condition. Spring water at house. Will keep 2 cows, 1 horse. Orchard of 20 trees. R. R. and P. O., Stowe, 6 miles. R. F. D. Price, $\$ 350 ; \$ 200$ cash; balance at 5 pel cent. Address H. E. Shaw.

\section{Storre}

Sallies farm of 20 acres; pasture, 5 woodland, 5; other acreage, 10 ; suitable for cultivation, 10. Estimated market value of wood and timber, $\$ 50$. Near saw mill, and plenty of work. House, $15 \times 20 ; 6$ rooms; fair repair. Barn, $15 \times 20$. Fences in fair condition. Will keep $1 \mathrm{cow}, 1$ horse. Spring water. Orchard of 10 trees. R. F. D. Telephone $1 / 2$ mile. R. R. station and P. O., Stowe, 51/2 miles. Price, $\$ 400 ; \$ 200$ cash; balance at 5 per cent. Address H. E. Shaw.

\section{Stowe}

"Eureka Stock and Dairy Farm" of 212 acres: pasture, 62; woodland, 50; suitable for cultivation, 100. Clay loam soil, free from stone, machine worked, no waste land. Estimated market value of wood and timber, $\$ 2000$. House, $50 \times 24$; L, $18 \times 24 ; 9$ rooms, 2 pantries, 6 closets; good repair. Barn, $40 \times 80$; cellar; good repair. Barn, $30 \times 40$; horse barn, $30 \times 40$; sheep barn, $20 \times 18$; corn barn, wagon shed; lumber for silo. Fences in fair condition. Will keep 50 cows, 4 horses. Running spring water. Orchard, 50 trees; several varieties. 500 sugar maples; new boiling equipment. Farm cut 100 tons of hay last season (1912) besides 18 acres ploughed. Railroad station and post office, $1 \frac{1}{2}$ miles. R. F. D., and telephone. Forty head stock, 3 horses, all farm machinery, including hay loader, side delivery rake, sulky plow, manure spreader, tedder, hogs and poultry. Price, $\$ 8,000$; $\$ 4,000$ cash; balance at 5 per cent. Twenty-five tons of hay for sale. Address G. W. Chapin.

\section{Stowe}

Farn of $82 \frac{1}{2}$ acres located in Stowe hollow: pasture, 30; woodland, 33 ; suitable for cultivation, 20. Enough wood and timber for farm use. House, $24 \times 30 ; \mathrm{L}, 15 \times 30 ; 8$ looms; good repair. Barns, $28 \times 38,18 \times 24$, cow stable, $14 \times 44$; cellar; good repair. Silo, $10 \times$ 11 x 17. Will keep 10 cows, 2 horses. Spring water. Apples, pears 
and plums. Sugar orchard; can hang 500 buckets. Good view of Mount Mansfield. Stowe electric railroad, 3 miles. P. O., 3 miles. R. F. D. On telephone line. District school, three-fourths mile. Price, including 10 cows, 2 horses, farm, dairy and sugar tools, $\$ 2000 ; \$ 1000$ cash, balance at 6 per cent.

\section{Waterville}

Farm of 25 acres: suitable for cultivation, 20 . House, $24 \times 28$; L, $18 \times 30 ; 8$ rooms; good repair. Barn, $18 \times 30$. Good fences. Will keep 5 cows. Spring running to house. 1200 apple trees and 15,000, more or less, in the nursery. This is a desirable property in many ways. Fine for fruit and good as a nursery proposition, which has one of the finest lists of varieties to be found. Personal property included if desired, which includes 50 colonies bees and 150 head high class poultry all in the best of shape and condition. $R$. R. station, Cambridge Junction, 5 miles. P. O., Waterville, 1 mile. R. F. D. and telephone.

\section{Waterville}

Farm of 124 acres: pasture, 40 ; meadow, 60 ; woodiand, 24 . Twostory house, in fairly good condition; some repairs needed. Average farm buildings. Soil, sandy loam. Meadows may be cut with machine. Will keep 12 or 15 head of stock. $1 \frac{1}{2}$ miles to village with churches, stores, P. O., etc. R. R. station, $5 \frac{1}{2} \mathrm{~m}$ miles. Distance from schoois, 50 rods. A few fruit trees-about a dozen. Would make a nice fruit farm; nursery on small farm adjoining where owner has set nearly 2000 young trees. Price, $\$ 1,800 ; \$ 500$ cash, balance at 5 per cent. Must be sold to close an estate. Addres Geo. L. Story, Administrator.

\section{Waterville}

"The Stanley Farm" of 148 acres: pasture, 93; woodland, 20; suitable for cultivation, 35. 100 acres is situated in Johnson, 48 acres with house in Waterville. House, $30 \times 40$; L, $18 \times 20$; 9 rooms; good repair. Barn, 20 × 30 ; cellar; good repair. Good fences. Will keep 15 cows, 3 horses. Spring water. A few apple trees. 1500 excellent sugar maples. 8 cows, 1 mowing machine, 1 plow, 1 harrow, 1000 sap buckets and spouts, 1 evaporator, 1 drawing tub, 2 sap holders, 1 sugaring-off pan. R. R. station and P. O., Johnson, 4 miles. R. F. D. Price, $\$ 2200$; one-third cash, balance at 5 per cent. For a quick sale to close estate, might shade this price a little. Address Geo. L. Story, Administrator.

\section{Waterville}

Farm of about 120 acres: pasture, 40 ; woodland, 40 ; about 75 acres suitable for cultivation. Estimated market value of wood and timber, $\$ 4000$. Only 1. mile to mill. Brick house, $271 / 2 \times 42$; L, about $15 \times 20$; 11 rooms; in good repair. Fine cellar, with hatchway, under all of house. Barn, $32 \times 70$, with lean-to, $30 \times 70$; cellar; good repair. Capacity, 100 tons. Will keep 20 cows, 2 horses. Fences in good condition. Plenty of common and two or three grafted trees. Has the best sugar house and best set up sugar orchard in town; 1450 tin sap buckets, nearly new, a Leader evaporator and iron arch and sugaring off outfit. nearly new and under the same roof; two years stock of dry wood in shed and plenty of storage for sap; also nearly one thousand feet of iron pipe that carries sap to the sugar house. Outfit represents about $\$ 1500$ outlay. Large henhouse, large wagon and tool house. The manure is under cover. T'he pasture is well watered at all times. Barn is nearly new. Running water to barn recently installed. $R$. $R$. station, Cambridge Junction, 5 miles. P. O., 1 mile. R. F. D. Telephone within 50 rods or so. Price, $\$ 6,000 ; \$ 3,000$ cash, balance at 5 per cent. Mills and timber lands also for sale. 


\section{Volcott}

Land for cottages: These lands are situated upon a beautiful body of water consisting of about 150 acres. It is conceded by many that the best bass fishing in Northern Vermont is found in this little lake. One of the nicest trout streams in this vicinity has its source in this lake, flowing southerly toward the village of Wolcott where it empties into Lamoille River, a larger stream well supplied with fish. The lake is only about twenty minutes drive from Wolcott village which is situated upon the St. J. \& L. C. R. R. and at the present time there is only one cottage upon this land, owned by Dr. G. C. Rublee of Hardwick, Vt. Supplies can be readily supplied by the farmers and steel boats can be supplied at any time. P. O., Wolcott, 3 miles. R. F. D. For further particulars, address G. H. Davis, R. F. D. No. 1

\section{ORANGE COUNTY}

\section{Braintree}

"Mount Pleasant." Farm of 170 acres: Pasture, 75; woodland, 52; other acreage, 40; suitable for cultivation, 40. Estimated market value of wood and timber, $\$ 1800$. R. R. siding for shipping wood and lumber, 2 miles, all down grade House, $33 \times 23$; L, $30 \times 21$; 9 rooms; good repair. Two barns, $28 \times 38$, each; cellar; good repair. Silo. Fences in good condition. Will keep 12 cows, 8 young stock, 3 horses. Spring water at house and barn yard. About 60 or 70 apple trees, consisting of Northern Spies, Greenings, Gravenstein and other varieties; also 3 pear trees and 1 white plum tree. Sugar orchard of about 400 trees. Deposit of talc in pasture. There seems to be quite an extensive vein of said mineral. A very desirable dairy farm. Milk and cream taken at door. School just across the street. R. R. station, E. Granville, 3 miles. P. O., Roxbury, 5 miles. R. F. D. and telephone. Price, $\$ 3,000 ; \$ 1,500$ cash, balance at 5 per cent. Good set of farming tools cheap if desired.

\section{Brookfield}

The Joseph Newell farm of 187 acres in East Brookfield: Pasture, 97; woodland, 40; suitable for cultivation, 50. 400 or 500 sugar maples and about 350,000 feet of timber. House, $32 \times 38$; L, $20 \times 40 ; 12$ rooms; good repair. Barns, $32 \times 42,36 \times 46$; shed, $32 \times 50$; fair repair. Silo; capacity, 37 tons. Will keep 20 to 25 cows, 3 or 4 horses. Owner pressed and sold 37 tons of hay from the 1911 crop. Fences in good condition. Running water at house and barns. 75 apple trees, onehalf grafted; a few pears and plums. Two good trout streams run through the farm. R. R. station, Williamstown, 8 miles. R. F. D. and telephone. Price, $\$ 1600 ; \$ 800$ cash, balance at 5 per cent. Address H. L. Newell, M. D., East Randolph, Vermont.

\section{Chelsea}

Farm of 190 acres: pasture, 70; woodland, 50; other acreage, 70; suitable for cultivation, 70 . Estimated market value of wood and timber, $\$ 4000$. House, $24 \times 32$; L, $30 \times 18 ; 9$ rooms; good repair. Barns, $30 \times$ $40,55 \times 26,34 \times 44$. Silo. Will keep 25 cows, 3 horses. Fences in good condition. Running water. Several varieties of apples. R. R. station, South Royalton, 14 miles. P. O., Chelsea, $2 \frac{1}{2}$ miles. R. F. D. and telephone. Farm is nicely divided into pasture and tillage for dairying or mixed farming. Is now cutting from 50 to 60 tons of hay. $y 0$ acres of this farm are free from taxation, excepting on the buildings. 40 acres of the tillage is level mow field. Practically all is good machine mowing. Price, $\$ 2500 ; \$ 1000$ cash, balance at 5 per cent. Address Percy J. Heath, Washington, Vermont. 


\section{Chelsea}

House, $40 \times 30$; L, $30 \times 25 ; 11$ rooms; in best of repair. Barn, $30 \times 20$; no repair needed. Garden. Good water. One of the best houses in town, two story, slate roof, large veranda. Carriage house, sheds. Barn and everything O. K. P. O. 15 rods. Telephone. Price, $\$ 4000$. Address E. D. Barnes.

Hotel property: Hotel has 40 rooms; in good repair. Livery stable. 10 acre pasture and large garden. Will keep 2 cows. Good water. R. R. station, South Royalton, 14 miles; Williamstown, 10 miles. 'Teleyhone. Price, $\$ 8000 ; \$ 4000$ cash, balance at 5 per cent. Practically everything in the hotel will go with the hotel. It is a bargain. Address E. D. Barnes, Proprietor.

\section{Corinth}

Farm 32 acres: pasture, 17; woodland, 8; suitable for cultivation, 7. Estimated market value of wood and timber, $\$ 400$. House, painted and blinded, $30 \times 24 ; \mathrm{L}, 32 \times 20 ; 7$ rooms; in good repair. Barn $44 \times 25$; good repair. Hen house. Carriage house, $20 \times 20$. Will keep 2 cows, 1 horse. Farm has kept 4 cows and a horse. Running water. Orchard of 25 trees, Fameuse, Peach apple, Pearmain, etc., Corinth Academy and Cookville Graded School; three stores, blacksmith shop, bobbin mill. A short distance to saw mill and creamery. R. R. station, Bradford, 10 miles. P. O., Corinth, $1 / 4$ mile. Telephone. Price, $\$ 1,500 ; \$ 1,000$ cash; balance at 5 per cent. Address F. W. Thurber.

\section{Corinth}

Farm of 400 acres: pasture, 200 ; wood land, 100 ; suitable for cultivation, 100 . Estimated market value of wood and timber, $\$ 500$, House, $35 \times 75$; annex, $30 \times 33 ; 32$ rooms; in fair repair. Large dining room suitable for dances; broad veranda up-stairs and down to the end and side of main house and entirely around annex. Barn, $40 \times 100$; cellar; good repair. Silo. Will keep 25 cows, 10 horses. Spring water. Orchard of 200 trees; Wealthy, Snow, Alexander, Peach, Tolman Sweet, Baldwin, and other varieties. Farm cuts 50 tons of hay. Bowling alley 90 feet long; two alleys. R. R. station, Bradford, 10 miles. P. O., Corinth, 3 miles. Price $\$ 4000 ; \$ 1,500 \mathrm{cash}$, balance at 5 per cent.

\section{Corinth}

Farm of 93 acres: pasture, 50; woodland, 17; other acreage, 26; suitable for cultivation. 40. Estimated market value of wood and timber, $\$ 500$. House, $25 \times 32 ; \mathrm{L}, 20 \times 22 ; 7$ rooms besides pantries and entries; sound and recently shingled. Barn, $38 \times 72$. Fences in fair condition. Silo, 40 tons. Will keep 10 cows, 2 horses. Running water at house and barn. Orchard of 55 grafted apple trees; over 30 bearing and others beginning to bear. A few pear, cherry and plum trees. There is an opportunity for a small business at sugar making at present and a larger one in the future. More than 400 buckets may be used now and there are several hundred young trees of all sizes that have been thinned out and are growing rapidly. P. O., Cornith, $3 \frac{1}{2}$ miles. R. F. D. and telephone. School, $1 / 4$ mile. Price, $\$ 1500 ; \$ 1000 \mathrm{cash}$, balance at 5 per cent. Address J. P. Sargent.

\section{Corinth}

Farm of 150 acres: pasture, 70 ; woodland, 30 ; other acreage, 10 ; suitable for cultivation, 40 . Fields very free from stone. Fistimated market value of wood and timber, $\$ 800$. House, $28 \times 32$; one story; 11 rooms; fair repair. Barn, $34 \times 34$; shed, $20 \times 40$; good repair. Barn, $30 \times 36$, with stable; fair repair. Fences in good condition; lots of steel Perfect fence. Will keep 10 to 15 cows, 4 horses. Spring water at 
house and barn and a well with never failing supply. An orchard with several Peach, Duchess, Greening, Ben Davis, Bethel, Snow, and other varieties. About one-third of woodland is covered with fine maples. About 1500 have been tapped; 2000 available. R. R. station, Bradford, 12 miles. P. O., $2 \frac{1 / 2}{2}$ miles. R. F. D., and telephone. $1 / 2$ mile to school house and $2 \frac{1}{2}$ miles to graded school. Price, $\$ 1,500$. Address $H . B$. White, Administrator, Topsham, Vermont.

\section{Corinth}

Farm of 150 acres: pasture, 40; woodland, 30; other acreage, 80 ; suitable for cultivation, 40 . Estimated market value of wood and timber, $\$ 700$ or $\$ 800$. House, $32 \times 28,2$ stories; 9 tinished rooms; in good repair. Barn, about $40 \times 40$; shed $18 \times 45$; good repaj. Fences in good condition; some Perfect fences. Farm will keep 10 or 15 cows, 2 horses. Plenty of water at house and barn. Orchard consists of a few young trees and some older growth. Fine fields nearly free from stones; good machine mowing. Sugar orchard of perhaps 1000 trees, and a gocd growth of hard wood on both places. In close proximity to mining enterprise. Can be made fine for summer boarders. Shade trees, etc. R. R. station, Bradford, 12 miles. P. O., Corinth, $2 \frac{1}{2}$ miles. District school, about $1 / 2$ mile; high or graded school, about $2 \frac{1}{2}$ miles. R. F. D. Telephone line near. Must be sold to close estate. Price, \$1,500. Address H. B. White, Administrator, Topsham, Vermont.

\section{Corinth}

Farm of 83 acres: pasture, 43 ; woodland, 15 ; suitable for cultivation, 25. Estimated market value of wood and timber, $\$ 200$. House, $25 \times 30$, with 6 rooms. Barn, $30 \times 38$; cellar; fair repair. Fences in fair condition. Farm will heep 5 cows, 1 horse. This farm nearly adjoins Corinth copper mining property. There is supposed to be a copper mine on this farm. Orchard of 25 trees. Railroad station, Bradford, 12 miles. P. O., Corinth, 2 miles. R. F. D. Price, $\$ 600$. Address H. B. White, Administrator, Topsham, Vermont.

\section{Fairlee}

Summer cottage on Lake Morey, with one-third acre of land. House, new 3 years ago, $20 \times 32$; 9 rooms; good repair. Running spring water in sink, bath room on top floor. Large piazza on three sides. Sleeping porch on top story. R. R. station and P. O., Fairlee, 1 mile. R. F. D. and telephone. Price including furniture, dishes and boat, $\$ 2100$; $\$ 1000$ cash, balance at 5 per cent. Address Geo. C. West.

\section{Randolph}

Summer residence situated on State road within one-third mile from very heart of town. A twelve acre lot consisting of tillage and pasture tor cow and horse. Fine garden. $1 \frac{1 / 2}{2}$ story house of 11 rooms, bath and wash room, village water, electric lights; broad porch on two sides. House commands most delightful view of mountain and valley. Fine barn with two stalls and room for a man. Only the main road divides this property from "Mari-castle Park" of many acres, lovely drives, summer houses, seats, etc. Commanding a fine view of town and mountains. This park, through the kindness of its owner, is "free to all humanity who will be decent." A desirable property in a most desirable town. Situated in the village district, but not in the school district. Would sell good surrey, light buggy, two horses and all kinds of garden tools. For further particular's address Miss Ella P. Skinner, 34 South Main Street. 


\section{Strafiord}

Farm of 400 acres: pasture, 170 ; tillage, about 120 ; balance in wood and timber. House, $26 \times 36$; L, $18 \times 40$. Horse barn at end of $\mathrm{L}, 26 \times$ 36 . Basement cattle barn, $40 \times 48$. Basement has shed and silo; tie-ups for 39 head of cattle. Hen house and storage shed. House and barn buildings in good repair. Orchard of 150 young apple trees, some plum and pear trees. Can tap 1000 sugar maples. R. R. stations, Sharon, 12 miles, and Ely, 13 miles. For futher pariculars address J. R. Hayes.

\section{Strafiord}

Farm of 170 acres: pasture, 50; suitable for cultivation, 25. House, $33 \times 29 ; \mathrm{L}, 13 \times 16 ; 10$ rooms; cellar under all of house; in very good repair. Barn, $49 \times 36$; in good repair. Fences in good condition. Farm will keep 12 cows, 2 horses. Water in barn and house. Quite a number of apple trees. With a little work considerable more land can be made suitable for cultivation. "We are just two old people here as our boys have left us. We can't run the farm." R. R. station, sharon, 9 miles. P. O., Strafford, $13 / 4$ miles. R. F. D. Price $\$ 1050$. Easy terms. Address William, H. J., or James Bassingthwaighte.

\section{Strafiord}

Farm of 120 acres: pasture, 50; woodland, 20; other acreage, 10; suitable for cultivation, 40. Estimated market value of wood and timber, $\$ 300$. Land in good state of cultivation. House, $24 \times 22 ; \mathrm{L}, 26 \times 18$; 8 rooms; in good repair. Barn, $88 \times 30$; fair repair. Fences in good condition. Silo, 35 tons. Farm will keep 15 cows, 2 horses. Spring water. 50 apple and 6 pear trees. Poultry houses for 250 hens. Farm is on good road. Reason for selling is old age and poor health. $R$. $R$. station, Sharon, 5 miles. P. O., South Strafford, 1 mile. R. F. D. and telephone. Price, $\$ 2000 ; \$ 1000$ cash, balance at 5 per cent. Address Geo. H. Brown, South Strafford.

\section{South Strafiord}

"Pleasant View Farm" of 235 acres: pasture, 110; woodland, 75; other acreage, 50; suitable for cultivation, 50. Estimated market value of wood and timber, standing, $\$ 1200$. A two-story house, $26 \times 30 ; \mathrm{L}, 20 \times 30$, L, $20 \times 24$; 19 rooms besides closets; good repair. Barn, $40 \times 100$, with cellar, slate roof; in good repair. Barn, 24 x 24 , for horses. Silo. Fences mostly wire, in good condition. Farm will keep 40 cows, 4 horses. Running water at house and barn. Orchard consisting of a few native and Duchess trees. Forty acres of meadow land is level, 10 acres, rolling. Fine corn and grass land. Pasture watered by never failing trout brook. Two new poultry houses. Insurance, $\$ 5,000$. Fine place for summer boarders. Is considered the best farm in town. $R$. $R$. stations, Sharon, 6 miles, Pompanoosuc, 9 miles. P. O., South Strafford, $1 / 2$ mile. R. F. D. and telephone. Price, $\$ 7000 ; \$ 4,500$ cash; balance at 5 per cent. Address Pinkham \& Varney.

\section{Tunbridge}

Wood and timber lot of 40 acres. Estimated market value of wood and timber, $\$ 2000$. Lot contains old growth maple, beech, yellow birch, red birch, basswood, ash and hemlock. R. R. station, South Royalton, 5 miles. P. O., Randolph Center, 4 miles. R. F. D. and telephone. Price, $\$ 2,000$ cash.

\section{Tumbridge}

Farm of 140 acres: pasture, 50; woodland, 25; suitable for cultivation, 60 . Estimated market value of wood and timber, $\$ 1,000$. House, $20 \times 30$; 9 rooms; good repair. Two barns, one $40 \times 30$; cellar; good re- 
pair. Silo. Fences in good condition. Will keep 12 cows, 2 horses. Running water. 75 apple, pear, plum and cherry trees, also blackberries and raspberries. Near a large quarry. Good sugar orchard; a sugar house and tools. R. R. station, South Royalton, 4 miles. P. O., Last Bethel, 2 miles. Telephone. Price, $\$ 2,500$ cash. Address F. H. Rea.

\section{Tunbridge}

Farm of 120 acres: pasture, 50; woodland, 25; suitable for cultivation, 40. Estimated market value of wood and timber, $\$ 1,200$. House, $20 \times 40 ; 7$ rooms; in very good repair. Two barns, and corn barn. One barn, 40 x 50, with cellar; good repair. Silo, 35 tons. Fences in good condition. Will keep 15 cows, 2 horses. Running water. Sixty apple and 20 plum trees. Good sugar orchard. Near neighbors, church, and a district school. R. R. station, South Royalton, 4 miles. P. O., East Bethel, 2 miles. This farm adjoins the farm above described. Telephone. Price, $\$ 3,000$ cash. Address F. H. Rea.

\section{Ver'shire}

Farm of 100 acres: pasture, 25; woodland, 25; suitable for cultivation, 50. Estimated market value of wood and timber, $\$ 200$. House, $28 \times 30$; L, $18 \times 24 ; 10$ rooms; fair repail. Barn, $44 \times 48$; cellar; fair repair. Horse barn, $30 \times 45,4$ stalls and cellar. Fences in good condition. Farm will keep 12 cows, 3 horses. Spring water. Orchard of 40 apple trees. Situated on the stage road from Vershire to Chelsea 5 miles to Chelsea, the county seat. 1 mile to church, stores, school, creamery, blacksmith shop and gristmill. In a good neighborhood. R. R. station, Ely, 13 miles. P. O., Vershire, 1 mile. R. F. D. On telephone line. Price, $\$ 1,350 ; \$ 500$ cash, balance at 5 per cent. Address A. H. Colton, Post .Mills, Vermont.

\section{ORILANS COUNTY}

\section{Albany}

The "William Hayden Farm" of 500 acres: pasture, 150; woodland, 200 ; other acreage, 150; suitable for cultivation, 100 . Estimated market value of wood and timber, $\$ 1,000$. Brick house, $35 \times 48 ; \mathrm{L}, 31 \times 26 ; 17$ rooms and bath; 10 closets and 3 halls; in fair repair. Large lawn enclosed with heavy granite curbing. Barns, $30 \times 96,43 \times 112,45 \times 118$, $44 \times 50,34 \times 45,36 \times 40$; fair repair. Fences in fair condition. Will keep 40 cows, 4 horses now. Can be made to lieep 60 cows. Orchard of 20 or 30 trees. This is a very desirable place. Clay loam soil. Nearly all machine mowing. Black river runs through the large field of 100 acres. House is richly furnished with black walnut, rosewood and mahogany, upholstered with hair cloth; heavy window draperies, rich velvet carpets, piano, etc. Will sell the house with furniture and as few acres desired or the whole farm. Is situated on the fine State road. R. R. stations, Orleans, 12 miles, Hardwick and Volcott, 13 miles. P. O., Albany, $1 \frac{1 / 2}{2}$ miles. Daily stage. R. F. D., and telephone line. Must be sold to settle estate. Price, $\$ 10,000$; enough cash so balance can be paid on mortgage at bank or elsewhere. For further particulars inquire of N. B. Williams, Administrator, North Craftsbury. Vermont.

\section{Barton}

Four hundred acres of wood and timber. Estimated market value, $\$ 2,000$. Mountainous and rocky and largely growing up with white birch and poplar. Sled roads to every part of the property. Railroad station Willoughby, 1 mile. P. O., Willoughby, 1 mile. Price, $\$ 2,000 ; \$ 1,000$ cash, balance at 5 per cent. For further particulars address W. S. McDowell, Orleans, R. F. D. 


\section{Barton}

A forty acre property: pasture, 15; suitable for cultivation, 25 . Overlooking Crystal Lake. Suitable for summer homes or permanent homes. Situated in the limits of the incorporated village of Barton. R. R. station about 50 rods. P. O., 1/2 mile. Price, easy terms.

\section{Barton}

Farm of 210 acres. House, $30 \times 40 ;$ L, $25 \times 30 ; 15$ rooms; good repair. Modern barn, $50 \times 100$; cellar; fair repair. Horse barn, $30 \times 40$; sheep barn $30 \times 50$. Fences in fair condition. Farm will keep 30 cows, 2 horses. Spring water; large stream, never failing. Native fruit in abundance. This farm has four tillage fields and two wood lots. Owing to this fact and that it is near a thrifty railroad village, part of the tillage and woodland might be sold off and still have a good farm left. Estimated value of wood and timber, $\$ 3,000$. The farm is located just north of Barton village which has a fine academy, public library, churches, stores, etc., within easy walking distance. R. R. station, three-fourths mile, P. O., one-half mile. R. F. D. and telephone. Price $\$ 8000 ; 40 \%$ cash. Address F. E. Nelson.

\section{Barton}

A money making farm of over 200 acres of rich farming land located only one-half mile from stores and less than one mile from railroad station. Land is suitably divided into tillage, pasture, and woodland, the latter comprising two of the best sugar orchards in town, with two camps equipped with evaporators and about 3,000 buckets. Could use 500 more. Lots of white ash timber and wood besides sugar maples. Modern high drive barn, $50 \times 100$; horse barn, $30 \times 40$; sheep barn, $30 \times 50$. Large, fifteen room house in good repair. Nice yard with maple shade and pleasant view. An abundance of variety of fruit. Buildings are supplied with large stream of never failing spring water. R. F. D. and telephone. Farm must be sold to settle estate. Address F. E. Nelson, Administrator.

\section{Barton}

A farm of 120 acres including stock and tools for $\$ 5,800.11 / 2$ miles to the hustling village of Orleans, Vermont, with stores, churches, (including Catholic), factories. This farm is pleasantly located on main road, R. F. D.; cream taken at door; telephone in house; the best of spring running water in house and at barn. Fruit crchard of good variety for home use. Land well divided in tillage, pasture and wood. Dark loam isoil, smooth, a little rolling, not very stony, a few boulders; all macnine work. Will winter 25 head and team and with a little work will winter 30 head. A good pasture for 25 head; well fenced and plenty of water and shade. There is about 200,000 feet of soft wood timber, spruce, fir alid cedar. Only $1 \frac{1 / 2}{2}$ miles to mill. Also one of the best sugar places in Orleans county of 1200 trees, mostly old growth, rigged for 1000 irees, very good equipments. Produces $\$ 200$ worth of sugar in a year. $1 \frac{1}{2}$ story house, $30 \times 30$, with an ell, $20 \times 40$, with one year's supply of wood in shed and yard. House newly clapboarded and painted. Piazza on ell. Good yard with two large maple shade trees. House has 8 rooms with cabinet kitchen and cellar; rooms in good repair. Stock barn $40 \times 60$, has a basement and a silo for 100 tons; stable arranged for 20 head. Horse barn, 20 x 40 , double boarded, has 4 stalls with basement. Carriage house, connected to dwelling house; a good sized tool shed, hen house, $12 \mathrm{x} 18$. Thirteen young cows, 2 yearlings, 6 calves, 2 pigs, 1 horse, all the hay and grain, 2 mowing machines, 1 horse rake, 2 plows, 2 harrows, wheel and smoothing, 2 cultivators, land roller, dump cart, new carriage, 1 express wagon, 2 lumber wagons, 2 pairs work sleds, 1 pung, 1 sleigh, 
1 pair of work harness, and a driving harness. Price, $\$ 5,800$, a reasonable amount down and balance on easy terms. Owner desires to sell as she is a widow in poor health. Address Mrs. Nora Holmes, Barton, Vermont.

\section{Derby}

Farm of 3 acres suitable for cultivation. House, $40 \times 30 ; 23$ rooms in good condition. Barn, $40 \times 25$; with cellar, $16 \times 23$; in good repair. Railroad station, Newport, 4 miles distant. 4 tenement house, wood shed, barn, ice house and blacksmith shop. Price, $\$ 5,000$; cash $\$ 2000$, balance on interest at 5 per cent. Address C. R. Doody, Derby, Vermont.

\section{Derby}

16 acre farm in Derby Center. Barn, $24 \times 24$ in good condition. Will keep 6 cows. Railroad station, Newport, 4 miles distant. Price, $\$ 1,500$; cash $\$ 500$, balance on interest at 5 per cent. Address C. R. Doody, Derby, Vermont.

\section{Brownington (Village of Evansville)}

Farm of 130 acres: pasture, 35; woodland, 15; suitable for cultivation, 80. Estimated market value of wood and timber, $\$ 1,000$. House of ten rooms in good repair. Barns, $50 \times 40,32 \times 28,40 \times 90$, with cellar, in good repair. Fences in good condition. Silo. No. tons capacity, 75. Will keep 25 cows, 4 horses. Water, running. Orchard, apple. Railroad station, Orleans, distance, 4 miles. Postoffice, Orleans, distance, 4 miles. R. F. D. and telephone. Smooth machine worked fields; nearly free from stone. Deep fertile soil. Short walk to school, church, stores, saw mill, blacksmith shop. Ties 32 head of cattle. Electric lights. Will winter 40 head of cattle and pasture 25 . Price, $\$ 4,000$; cash, $\$ 2,000$. Address H. P. Leland, Orleans.

\section{Craftsbury}

Farm of 100 acres: pasture, 35; woodland, 35; other acreage, 30 ; suitable for cultivation 55. Estimated market value of wood and timber $\$ 1,500$. House, $24 \times 16 ; \mathrm{L}, 24 \times 16 ; 9$ rooms; in good repair. Fences in good condition. Will keep 15 cows, 2 horses. Running water. Orchard of 20 different kinds of fruit. Fine sugar bush of 1,600 rock maples, level and smooth area. Farm is moist and is a great hay farm. Sugar tools are new. New DeLaval separator. Railroad station, Wolcott, $6 \frac{1}{2}$ miles, level road. Post Office, Craftsbury, 5 miles; $2 \frac{1 / 2}{2}$ iles to two others. R. F. D. Also on Wolcott stage route. Owner is teacher and will sell soon. Price, including tools, $\$ 3,500 ; \$ 1,000$ to $\$ 1,500$ cash, balance at 6 per cent. Address L. M. Darling, Canaan, Vermont.

\section{Greensbor'o}

Farm of 120 acres: pasture, 60; woodland, 25; other acreage, 35; suitable for cultivation, 60. Estimated market value of wood and timber, $\$ 1,800$. House $24 \times 30 ; \mathrm{L}, 20 \times 24 ; 10 \mathrm{rooms}$; in very good repair. Horse barn connected to $\mathrm{L}, 24 \times 30$; in good repair. Two-story barn, $40 \times 60$, with cellar; in good repair. Silo, 100 tons. Fences in good condition. Farm will keep 16 cows, 3 horses. Running water athouseand barn. Some grafted fruit. Sugar lot equipped with 1500 new metal buckets and covers, evaporator, $4 \times 16$, two good gathering tubs, metal storage tank of 40 barrels capacity. Good market for all early vegetables at good prices. Overlooks Caspian Lake, one-half mile distant. Fine location for cottages. R. R. stations, East Hardwick and Greensboro Bend, 5 miles. P. O., Greensboro, 3 miles. R. F. D. and telephone. Price, $\$ 3,000 ; \$ 1,000$ cash, balance at 5 per cent. Address J. E. Baird.

\section{Irasburg}

160 acre farm: pasture, 60; woodland, 50; other acreage, 50; 
suitable for cultivation, 70. Estimated value of wood and timber, $\$ 2,000$. House, $66 \times 24,8$ rooms in good repair. 2 barns, $40 \times 82$, new. Fences in good condition. 90 ton silo. Will keep 25 cows and 3 horses. Never failing spring water. Orchard of 100 grafted native apples, also pear trees. Good sugar orchard. All right for 1600 trees. Made 3600 lbs. sugar in the spring of 1913 . Railroad station, Orleans, 8 miles distant. R. F. D. and telephone. Will sell stock and tools with farm if desired. Price, $\$ 6,000 ; \$ 3,000$ cash; balance on interest at 5 per cent. Address C. F. Webster, Irasburg, Vt.

\section{Westmore}

Cottage, $36 \times 16$, with porch $6 \mathrm{ft}$. wide, on three sides. Cottage lot. Barn, $16 \times 18$. A well built cottage and barn with basement under both. The house is boarded with good lumber and covered with two-ply Paroid roofing on sides and ends and painted two coats with lead and oil. The roof is shingled with good cedar shingles. Price, $\$ 800 ; \$ 200$ cash; balance at 5 per cent.

\section{RUTLAND COUNTY}

\section{Benson}

Farm of 274 acres, known as the Fred May farm; nearly 50 acres woodland, mostly covered with spruce and pine; good meadows and pastures. Buildings sufficient for the place and in fair condition, with running water to same. This farm will carry a large stock. It is located on main highway, not far from the village of Fair Haven, is more than ordinarily level, is considered one of the best farms in town, and must be sold to settle an estate. Address Robert Morris, Adm., Fair Haven.

\section{Brandon}

Farm of 394 acres, with 170 acres in pasture, 124 acres in,woodland, 100 acres suitable for cultivation; a considerable part of the pasture can be plowed. This farm lies back on the hills in a healthful section on good road and the buildings are in good repair. Estimated market value of wood and timber, $\$ 2000$, on the stump. House, $30 \times 40$, with L, $20 \times 30$; number of rooms 11; house in good condition. Barn, $30 \times 60$, with cellar; another barn, $24 \times 36$, with lean-to for stable, $22 \times 32$ and $20 \times 31$; also horse barn, $20 \times 30$; hog pen, $18 \times 20$; shed, $20 \times 30$; granary, hen-house, silo, shop and ice house. Good fences. Spring water runs to house and barn. Will keep 50 cows, 6 horses and other stock. 10 young apple trees and as many more old ones; cherries and plums. The farm consists of good potato, grain and corn land. Maple sugar orchard in which 1000 buckets may be set. Railroad station and post office, Brandon, 7 miles. R. F. D. and telephone. Price, $\$ 4500 ; \$ 2,500$ cash, with the balance at 5 per cent. Address Willis V. Farr, Burlington, Vt.

\section{Lake Bomoseen}

Two houses with half acre of land; houses, $20 \times 24$, with L, $10 \times 12$, in good repair; 9 rooms. Water from driven well. Railroad station, Hydeville, 4 miles. Post office, Bomoseen, 1-16 of a mile. About 15 rods from trolley station. Telephone connections. Best cottage has lake front and electric lights; rents furnished for $\$ 15.00$ per week. Price, $\$ 4,200 ; \$ 2,000$ cash; balance at 5 per cent. Will divide property, one house, $\$ 2,500$, one house, $\$ 1,700$. Address H. M. Redfield.

\section{Castleton}

Village property. 7 room house, all modern improvements, bath, hot and cold water, furnace heat; hard-wood floors. Cistern and driven well. Grounds, $250 \times 150$ feet, with large field on one side. Price, $\$ 3,500$. Address .Mrs. Graydon W. Moore, Castleton, Vt. 


\section{Chittenden}

Farm of 225 acres, with 125 acres in pasture, 50 acres in woodland, and 50 acres suitable for cultivation; estimated market value of wood and timber, $\$ 2,500$. House, $24 \times 26 ; \mathrm{L}, 15 \mathrm{x} 24 ; 12$ rooms. Barn, $50 \mathrm{x}$ 100, with cellar. House and barn in best repair. A silo of 75 tons capacity. Fences in fair condition. Will keep 25 cows and three horses. Plenty of good water. House is furnished with hot and cold water, water closet, bath tub and furnace. Cemented cellar in both heuse and barn. Orchard of 50 trees. Railroad station and post office, Rutland, 6 miles. R. F. D. and telephone. Price, $\$ 5,000 ; \$ 2,500$ cash; balance at 6 per cent.

\section{Fair Haven}

Farm of 113 acres: pasture, 43; woodland, 20; suitable for cultivation, 50. Estimated market value of wood and timber, $\$ 500$. House, 25 x 25, with L, $20 \times 20$; number of rooms, 11 . House in good repair. Barns, $50 \times 30$ and $26 \times 36$, with cellar; in good repair. WVill keep 15 cows and 3 horses. Water from well and cistern. Orchard of 75 trees; many kinds of apples; plum and pear trees; farm well adapted for fruit growing. Railroad station and post office, Fair Haven, 3 miles, also trolley station. R. F. D. and telephone. Price, $\$ 3,500 ; \$ 1,500$ cash, with balance at 5 per cent. Address Willis J. Bartholomew.

\section{Fair Haven}

Farm of 356 acres: pasture, 100 ; woodland, 56 ; suitable for cultivation, 200; estimated value of wood and timber, $\$ 1,000$. House, $30 \times 30$, with L, $20 \times 30$; number of rooms, 20; house in good repair. Barns, 100 $\mathrm{x} 60$, and $60 \times 50$, in good repair; also silo and other small buildings, barns have capacity of 142 tons. Fences in good condition. Farm will keep 75 cows and 6 horses. Water from artesian well. Orchard of 25 trees. This farm was bought and repaired by a rich man who lived on it until he was too old to run it. It is considered one of the best stocli farms in the community and is favorably located for a milk route. It contains a slate vein partly developed. Railroad station and post office, Fair Haven, 1 mile; also electric railroad near by. Telephone connections. Price, $\$ 15,000$; $\$ 3,000$ cash, with balance at 5 per cent. Address Willis J. Bartholomew.

\section{Hubbardton}

Farm of 10 acres: pasture, 4; woodland, 1; other acreage, 1; suitable for cultivation 4. Estimated market value of wood and timber, $\$ 100$. House, $18 \times 24$, with L, $12 \times 14$, in fair condition; number of rooms, 7 . Barn, $26 \times 32$, with cellar, in poorer condition. Fences in fair condition. Will keep one cow and one horse. Plenty of water. Orchard of 20 apple trees. Trout brook runs through pasture. Railroad station, Castleton, 8 miles. Post office, Hubbardton, $1 / 2$ mile. On telephone line. Price, $\$ 600$; $\$ 200$ cash, with balance at 5 per cent. Address H. M. Redfield.

\section{Middletown Springs}

Farm of 35 acres; woodland 20 ; suitable for cultivation, 15; marliet value of wood and timber, $\$ 1,200$. No house or barns. Fences in good condition. Orchard of 60 trees, with young trees suitable for grafting. Farm located on the automobile road between Rutland and Niddletown Springs, directly on the summit or height of land; a beautiful view and an ideal spot for a summer residence. Railroad station, West Rutiand, 8 miles. Post office, Middletown Springs, 3 miles. R. F. D. and telephone. Price, $\$ 700 ; \$ 400$ cash, with balance at 5 per cent. Address Richard E. Buxton, Box 98 .

\section{Middletown Springs}

Farm of 420 acres: pasture, 150; meadow land, 100. Contaills severul 
thousand sugar maples. Plenty of spring water. Will keep 40 or 50 cows. Address James McMorrow.

\section{Middletown Springs}

Farm of 175 acres: pasture, 55; woodland, 55; other acreage, 5; suitable for cultivation, 60 . House, $30 \times 40$, with L, $18 \times 24$, in good repair; number of rooms, 10 . Barn, $50 \times 72$, in good repair. Fences in fair crindition. Will keep 15 cows and 3 horses. Excellent water supply. Plenty of fruit and chance for more. Beautiful scenery and an excerient place for keeping summer boarders. Many summer people come to this section every year. Three railroad stations within a distance of 9 miles. Post office, Middletown Springs, 2 miles. R. F. D. and telephone. Electric transmission line within 5 rods of the house. Price, $\$ 4,500$; hall in cash and balance at 5 per cent. Address A. W. Gilman.

\section{Proctor}

One and one-half acres good land. House, $26 \times 22$, with L, $18 \times 18$, House in best of condition, hard wood floors, hot and cold water, cellar with concrete floor under whole house. Horse barn, $20 \times 30$, with 4 stalls; hay barn, $20 \times 30$; hen house, carriage room, wagon shed and corn crib. Water in house and barn. Orchard of 14 apple trees, pear tree and plum tree. Railroad station and post office, Proctor 3/4 mile. Telephone connections. Price, $\$ 2,800 ; \$ 1,800$ cash; balance at 6 per cent.

\section{Rutland}

Farm of 241 acres: pasture, 80 ; woodland, 80 ; other acreage, sí; suitable for cultivation, 100 . House, $40 \times 30$, with $\mathrm{L}, 40 \times 28$, in fair repair; 16 rooms. Shed, $24 \times 12$. Two barns, $36 \times 28$; one barn, $40 \times 30$, and one $40 \times 28$, in fair repair. Water brought from brook by ram. About 40 apple trees and a few plum and pear trees. Railroad station and post office, $3 \frac{1}{2}$ miles. R. F. D. route. Price, $\$ 5,000 ; \$ 2,500$ cash; balance at 5 per cent. Stock and tools may be included at agreed price. Address Frank B. Fuller.

\section{Rutiand}

A small farm of 11 acres suitable for cultivation. House, $25 \times 22 ; \mathrm{L}, 30$ $\mathrm{x} 20$, in good repair; number of rooms, 10 . Barn, $48 \times 24$, in good repair. Farm used for gardening, city water furnished. Orchard of 12 apple trees, also plum and cherry trees. Excellent soil, free from stones and in a very high state of cultivation. A large plot of alfalfa growing. Good opportunities for poultry raising. Farm within city limits and street:s laid out as far as this place. Railroad station and post office, Rutland, $1 \frac{1 / 4}{4}$ miles. Telephone and city delivery of mail. Price on application. 61 Field Ave.

\section{Wallingford}

Farm of 175 acres: pasture, 100 ; woodland, 20 ; suitable for cultivation, 55. Estimated market value of wood and timber, $\$ 800$, on the stump. There are between 200 and 300 sugar maples. House, $30 \times 28$, with L, 24 x 24 , also summer kitchen and wood shed connected with house, all in good repair; number of rooms, 10. Three barns, with cellar, in good repair, $34 \times 40 ; 30 \times 40 ; 28 \times 32$. Will keep 30 cows and three horses. Water furnished by well, cistern and brook. A few young apple trees. Buildings are beautifully situated just outside the village limits on the banks of Otter Creek, which borders the farm for about 70 rods. Farm also borders highway for 80 rods. Eltin Lake is situated about 75 rods back from the house and is bordered for two-thirds of its circumference by this farm. Fine site for summer residences or summer cottages near the lake. A machine worked field, free from stone. Spring watered pasture. Nearly a mile of woven wire fencing with locust posts. Wallingford is a thriving village 10 miles south of Rutland on the Rutland Railroad and 22 miles 
north of Manchester. Six-hour train service from New York. Wallingford has three churches, six stores, fine public library, new town hall, high school, large hotel, creamery, electric lights, water system and fire department. Railroad station and post office, Wallingford, $1 / 2$ mile. Telephove and electric lights with village water within 40 rods. Price, $\$ 8,000$. Ad. dress H. H. Waldo.

\section{East Wallingford}

A farm of 500 acres: pasture, 300 ; woodland, 100 ; suitable for cultivation, 100. Estimated market value of wood and timber, $\$ 4,000$. House, $26 \times 47$, with L, $19 \times 27$; 14 rooms, in very good repair. Barn, $36 \times 100$. with cellar, in good repair. Fences in good condition. Silo of 150 tons capacity. Will keep 75 cows, 8 horses. Good spring water at house and barn. Orchard of 25 trees. Railroad station and post office, East IVallingford, one mile. R. F. D. and telephone. This farm is a very good one, all in first class condition; excellent opportunity for a stock farm. Price. $\$ 16,000 ; \$ 11,000$ cash and balance at 5 per cent. Address Peter Pelkey.

\section{IVells}

One half acre of land with house $20 \times 26, \mathrm{~L}, 12 \times 1 \mathrm{~S} ; 10$ rooms. Barn, $21 \times 24$ with cellar. This is a new house, downstairs finished in oak mission; upstairs finished in pine, natural. Concrete foundation, and sleeping porch. Five minutes walk from Lake St. Catherine, near trout stream, fine shaded lawn. "Complete bathroom, electric lights, hot air heater, and would make an ideal summer home. Barn fitted for either garage or stable. Large garden. Railroad station, Granville, N. Y., 3 miles. Post office, Wells, 15 rods. Price, $\$ 3000$ cash. Address Lester L. Hopson.

\section{IVASHINGTON COUNTY}

\section{Cabot}

Farm of 200 acres: pasture, 65; woodland, 60 ; suitable for cultivation, 75. Estimated market value of wood and timber, $\$ 2,500$. House, $30 \times 35$, with L, $20 \times 40$, in good repair; number of rooms 13, with five closets. Barn, $45 \times 56$, in good repair; barn cellar and silo $11 \times 24$; horse barn $24 \times 56$ connected with barn. Woodshed $24 \times 28$ connected with house. Will keep 25 cows and two horses. Farm cut 65 tons hay in 1912. A never failing well supplies water. Orchard of 50 trees, native fruit. Railroad station, Walden, 5 miles; post office, Cabot, $2 \frac{1}{2}$ miles. R. F. D. and on telephone line. Price, $\$ 3,500 ; \$ 2,500$ cash, with balance at 5 per cent. Appiy Will Adams.

\section{Marshfield}

Farm of 120 acres; pasture 70 ; suitable for cultivation 25 to 30 . Estimated market value of wood and timber $\$ 6 u 0$. House $32 \times 22$ with $\mathrm{L}$ $24 \times 18$ in excellent repair, 8 rooms. Barn $45 \times 72$ with cellar, in good repair. Fences in good condition. Silo of 50 tons capacity. Will keep 15 to 18 cows and 3 horses. Never failing water supply. Orchard of 65 trees, including McIntosh Reds, Fameuse, Spring, Pound Sweet, Duchess, Russets, Wolf River, Pippins, Andrew's Favorite, St. Lawrence, Talman Sweet, Red Astrachan, Ben Davis and other kinds. There is a spiendid sugar orchard on the place, a good trout brook running the entire length of the farm, privately stocked, and a ten or twelve acre trout pond, privately stocked. The land is in good condition. Railroad station, Marshfield, $13 / 4$ miles; post office, Marshfield, $3 / 4$ mile. R. F. D. and telephone. Price of farm stock and tools on application. Address Ernest E. Tanner.

\section{East Montpelier}

A large stock farm of about 450 acres; suitable for cultivation 120 ; pastures well watered. A large quantity of hard and soft wood lumber, 
including a cedar swamp with thousands of cedars suitable for posts. Maple sugar orchard of 800 trees. Soil deep and rich and farm nearly level. Will carry 100 head of cattle and 6 horses. Produces 150 tons of hay and a large amount of other crops, from 1200 to 1500 bushels of grain are usually raised. Large silo and last year 30 acres of corn were raised. Modern 2 story house of 18 rooms. Barn $54 \times 104$, also horse barn, sheds and garage. One of the finest sets of farm buildings in this part of the state. Cottage convenient for hired help. Abundance of spring water in house and barn. Splendid trout brook on farm. Considered one of the best farms in Washington County, 4 miles to Montpelier and 5 miles to Barre. Is well adapted for a milk or stock farm. Price $\$ 24,000$. Apply H. M. Farnham, Montpelier, Vt.

\section{East Montpelier}

Farm of 35 acres: pasture, 15; woodland, 10; suitable for cultivation, 10. Estimated market value of wood and timber, $\$ 500$. House, $36 \times 26$, in good repair; 6 rooms. Barn, $36 \times 23$; hen house, $40 \times 12$. Fences in good condition. Orchard of 30 apple trees. There is an abundance of water on the place. It is only 3 miles from the State House and was purchased for gardening and the raising of poultry and swine, but on account of the poor health of the owner it is offered for sale. Railroad station and post office, Montpelier, 3 miles. Price, $\$ 1,400$. Address A. E. Wallen, 132 Main St., Montpelier.

\section{Montpelier}

For Sale. Splendidly located. Farm of 117 acres within the city limits, on level road, $1 \frac{1 / 2}{2}$ miles from the Capitol Building of the State. Evenly divided, without stone or ledge in tilled land, all machine worked; about 35 acres level meadow capable of producing immense crops, salable in one of the best market towns in Vermont. 2000 cords wood and some timber. 17 room house, all conveniences, furnace heat, set tubs, etc. Spring and city water. Large barn, slate roof, etc., and new cottage in woods adjoining city park. Buildings in good repair. Hay in barn and farming tools-no stock. A splendid home in a beautiful city, excellent markets, and within a few years a building lot proposition. All details price, etc., on application. C. A. Pitkin, Montpelier, Vt.

\section{Northfield}

Farm of 400 acres: pasture, 60 ; woodland, 300 ; suitable for cultivation, 40. House, $24 \times 28$, in fair condition; number of rooms, 7 . Barn, 40 $\mathrm{x} 30$, in fair condition. Fences in fair condition. Will keep 8 cows and 2 horses. Spring water on the place. Several fruit trees on the farm. Railroad station, Roxbury, $4 \frac{1}{2}$ miles, post office, Northfield, 7 miles. On R. F. D. route. Price, $\$ 2,000 ; \$ 1,000$ cash, with balance at 6 per cent. Address E. Barton Whitney.

\section{Northfield}

A timber lot of 160 acres which can be reached at any season of the year, $3 \frac{1}{4}$ miles from railroad station with no hills to climb. Contains a lot of spruce and hard wood timber. A sugar orchard of s00 trees which can be doubled in number in a short time.

Also a residence in village, 5 minutes walk from station. 11 room house, with hot water heat and hard wood floors, all new. Barn for 6 cows and 7 horses. 7 acres of land. A fine orchard and all kinds of small fruit. This place is well adapted to the keeping of summer boarders. House can be arranged for two families. Address F. A. Joslyn.

\section{Roxbury}

Farm of 75 acres: pasture and woodland, 45; suitable for cultivation, 
30. Estimated market value of wood and timber, $\$ 1,000$. House, $20 \times 30$, with $\mathrm{L}, 12 \times 20$, in good repair, 5 rooms. Barn, $30 \times 40$. Fences in good condition. Will keep 7 cows and 2 horses. Running water in house and barn. Orchard of 25 trees of various kinds. This is excellent hay land. The place contains 1000 sugar maples, also butternut and walnut trees. Railroad station and post office, Roxbury, 1/4 mile. Price, $\$ 1,000$. Address F. H. Merrill.

\section{Waitsfield}

Farm of 100 acres; pasture, 50; woodland, 20; other acreage, 30 ; suitable for cultivation, 50. Estimated market value of wood and timber, $\$ 1,500$ to $\$ 2,000$. House, $25 \times 60,11$ rooms, in good repair. Barn, $30 \mathrm{x}$ 40. Horse barn, $25 \times 38$, in fair repair. Fences in good condition. Silo of 30 tons capacity. Will keep 10 cows and 2 horses. Orchards of 90 apple trees, 2 pears, several plums. A sugar orchard of 600 trees, a fine one very handy by. Apple orchard one of the best and produces 100 barrels per year of standard fruit. One of the best watered farms in this county, 5 never failing springs and a good trout brook, has been stocked with 26,000 trout. Mowings are level and smooth. 75 rods to a first class school and about the same to four neighbors. Will pasture from 20 to 25 cows and is being sold on account of old age, the present owner being 80 years old and having owned and lived on the farm for 50 years. It is two miles to Waitsfield village. Skimming station 75 rods from barn, where either milk or cream is taken. Railroad station, Middlesex, 12 miles. Post office, Waitsfield, 2 miles. R. F. D. and telephone. Price, $\$ 1400$; $\$ 600$ cash; balance at 5 per cent. Address J. H. Neill.

\section{Wateroury}

Farm of 100 acres: forty acres in pasture; woodland, 15; suitable for cultivation, 45. House, $40 \times 36$, in good repair, 9 rooms. Horse barn, $32 \times 52$, with cellar. Hay barn, $30 \times 40$. Cow stable, $100 \times 15$. Piggery, $24 \times 40$. Fences in good condition. Silo with 40 tons capacity. Will keep 35 cows and 4 horses. There is an ample supply of running water from three different springs. A maple orchard of about 400 trees is an important feature of the property and the place is equipped with sugar making utensils. This farm is beautifully situated on what is known as Blush hill, overlooking the village of Waterbury. It would make an ideal location for a summer home for a family or for a club. Owing to the abundance of pure spring water a fish pond could be established easily. The contour of the land is such that very fine golf links could be laid out without difficulty. The distance to the railroad station in Waterbury is only $1 \frac{1 / 2}{2}$ miles and the place has the benefit of an R. F. D. route and telephone connections. Waterbury is on the main line of the Central Vermont Railway, 3 hours ride from Montreal, 7 from Boston and 9 hours ride from New York. Waterbury has a population of about 3300 , a fine water system, an adequate sewer system, good streets, 10 miles of concrete walks, excellent church and school facilities, and one of the best hotels in the state. Price of farm, $\$ 10,000 ; \$ 3,000$ cash with balance at 5 per cent. Address H. C. Whitehill, Waterbury.

\section{WINDHAM COUNTY}

\section{West Dummerston}

Farm of 70 acres: pasture, 35; woodland, 15 ; 6 miles from Brattleboro. Estimated market value of wood and timber, wood $\$ 8.00$ per cord, logs $\$ 15.00$ per thousand. $1 \frac{1 / 2}{2}$ story house, with $L$ in good repair, 7 rooms. Barn, $30 \times 40$, in good repair. Will keep 10 cows and 2 horses. Running water. Orchard of Baldwins and Greenings. This farm is in good state of cultivation, cuts all No. 1 hay, nice sugar lot, house and tools. Blacksmith shop, large hen house and yard. Railroad station, West Dum- 
merston, $3 / 4$ mile; post office, West Dummerston, $3 / 4$ mile. R. F. D. and telephone. Price, $\$ 1,700 ; \$ 850$ cash; balance at 6 per cent. Mrs. E. J. Wilkins.

\section{Guilford}

Three-fourths of an acre of good land. House, $30 \times 36$, in fairly good repair. Barn, $14 \times 20$, in fair condition. Water obtained from well. This place is situated in a small village with church, school, post office, and store within 5 minutes walk. Railroad station, Brattleboro, 10 miles. Post office, Green River. Price $\$ 300$. Address Mrs. A. E. Thomas, 1 Pleasant St., Brattleboro, Vt.

\section{Jamaica}

Farm of 325 acres: 127 acres suitable for cultivation, balance pasture and woodland with a nice lot of glowing pine estimated now at 100,000 feet; also a large sugar orchard, a new sugar house equipped with a new evaporator and 1400 new galvanized buckets. Large 10 room house. Two barns, $30 \times 40$, with shed, $18 \times 30$, attached to one and lean-to, $18 \times 30$ attached to the other. Running water at house and barn. This farm is located $2 \frac{1 / 4}{4}$ miles from railroad station, post office, creamery, church and schools. Price, $\$ 10$ per acre, part cash, balance on easy terms. Address R. I. Holbrook, Townshend, Vt.

\section{Londonderry}

Farm of 300 acres; pasture, 125; woodland, 125; other acreage, 50; suitable for cultivation, 40. Estimated market value of wood and timber, $\$ 3,000$ to $\$ 3,500$. House, $40 \times 26$, with $\mathrm{L}, 48 \times 19$, in good repair. 9 rooms on ground floor. Barn, $40 \times 50$, with cellar. Fences in good condition. Will keep 10 to 15 cows and 3 horses. Never failing supply of running water. Orchard of 150 trees, including Baldwins, Greenings, Maidens Blush, Blue Pearmains, Red Astrachans, Strawberry and Snow apples and other varieties. This farm lies in a valley, has a sugar orchard of 450 trees, the barn is new, and both house and barn are slated. There is a driveway into the gable end of the barn so that all the hay can be pitched down without the need of a horse fork. There is a nice yard, also fine shade trees in front of the house. The place is situated on the Mancheschester stage route. Railroad station, South Londonderry, $4 \frac{1 / 4}{4}$ miles. Post office, Londonderry, $1 \frac{1 / 4}{4}$ miles. Telephone and mail delivered by stage. Price, $\$ 4,000 ; \$ 3,000$ cash, with balance at 5 per cent. This price does not include the sugar tools. All tools and stock may be had at reasonable prices.

\section{Newfane}

Farm of $6 \frac{1}{2}$ acres: pasture, 1; woodland, 1; suitable for cultivation, $41 / 2$. Will keep one cow and one horse. Supply of brook and spring water. A few apples are just beginning to bear. This place is suitable for a summer residence, for a poultry farm or for the raising of strawberries and small fruits. It is also adapted to orchard purposes. It is located on the main road. No house or barn. Railroad station and post office, Newifane, $3 / 4$ mile. Price, $\$ 250 ; \$ 100$ cash and balance at 5 per cent. Address $\mathrm{H}$. A. Carpenter.

\section{Newfane}

Farm of 110 acres; pasture, 40; woodland, 25, suitable for cultivation, 40. Estimated market value of wood and timber, $\$ 1,500$. House of nine rooms, in good repair. Barn, $40 \times 80$, with cellar, also large silo. Fences in good condition. Will keep 25 cows and three horses. Supply of spring water. Large orchard of early and winter apples. This is considered one of the best farms in Newfane and is. situated near the county buildings. There are a large number of sugar maples on the place, a good 
sugar house and 700 buckets. This place is 10 miles from Brattleboro by rail. Railroad station and post office, $1 \frac{1}{2}$ miles. Telephone connection. Price, $\$ 4,000 ; \$ 2,000$ cash with balance at 5 per cent. Apply J. H. Ware, Townshend.

\section{Newfane}

Farm of 140 acres; pasture, 40 ; woodland, 70 ; suitable for cultivation, 30 . House, $24 \times 34$, with 9 rooms, in good repair. Barn, $38 \times 48$, with cellar. Fences in fair condition. Will keep 8 cows and 2 horses. Running water. Apple orchard, also pears and grapes. Sugar orchard of 350 trees. Timber recently cut over, but many small trees are left. Farm is situated on the main road. Railroad station and post ofice, Newfane, $13 / 4$ miles. R. F. D. and telephone. Price, $\$ 2,200$. Will sell crops and tools at reasonable price. Address A. L. Lockwood.

\section{Putney}

Fair View Farm of 200 acres: pasture, and woodland, 140; suitable for cultivation, 60 . It is estimated that there are 2,000 cords of hard wood, spruce, pine and hemlock on the place, House, $36 \times 40$, with $\mathrm{L}$, $14 \times 40$, in good repair, but house needs painting. Number of rooms, 20 , including 4 halls and two attics. Barns in good repair, one $30 \mathrm{x} 50$, with cellar stable, one $30 \times 40$; storage barn, $28 \times 36$. Fences in good condition. Will keep 20 cattle and 4 horses. Running water in house and barn. Orchard of 50 apple trees, 6 pear, 6 plum, 6 cherry and 12 peach trees. Railroad station, 4 miles. Post office, Putney, 3 miles. Free mail delivery and telephone lines short distance away. The land slopes to the east, there are two lots adapted to peach or other orchard purposes or small fruits; also two other lots best adapted to grass, although grain can be successfully raised. The farm cuts from 40 to 50 tons of hay but this amount can easily doubled. There are 30 acres in one meadow. Price, $\$ 5,000$. Apply to Miss Edith Holton.

\section{Saxtons River}

Farm of 150 acres: pasture, 60 ; woodland, 50; suitable for cultivation, 40. Estiniated market value of wood and timber, $\$ 100$. House, 24 x 24, with L, $24 \times 18$, in good repair, 8 rooms. Barn, $56 \times 30$, with cellar, in good repair. Fences in fair condition. Silo with capacity of 70 tons. Will keep 30 to 35 cattle and 2 horses. Running water to barn. Orchard with fruit enough for home use. This place is situated on a good road leading from Saxtons River to Westminster West. It is just outside the village and within $3 / 4$ mile of Vermont Academy. The land is easily cultivated. A good sized brook runs through the farm. There are two other barns besides those mentioned, also slaughter house. Railroad station, Bellows Falls, 5 miles. Post office, Saxtons River, $1 / 2$ mile. R. F. D. and telephone. Price, $\$ 4,500$; part cash, balance at 5 per cent. Apply WV. W. Barry.

\section{Townshend}

Farm of 250 acres: pasture, 50; woodland, 100; other acreage, 25; suitable for cultivation, 75 . Estimated marlket value of wood and timber, $\$ 1,000$. House, $30 \times 60$, with $\mathrm{L}, 18 \times 24,13$ rooms, in fair repair. Barn, $48 \times 36$, with cellar, in good repair. Fences in good condition. Silo, 12 $\mathrm{x} 30$. Will keep 15 cows and 3 horses. Water at house and barn. There is an orchard of 100 pear and apple trees. A nice level sugar orchard on this farm can set 1,500 buckets, a set of good sugar tools for 700 trees goes with the farm and other farming tools all in good condition, and some stock. One can drive all over this farm. It would be a good place for summer boarders or a stock farm. Railroad station and post office, Newfane, 5 miles. Telephone and will soon have R. F. D. Price $\$ 2,000$; $\$ 1,000$ cash; balance at 6 per cent. Address E. E. Phillips. 


\section{Townshend}

Farm of 160 acres: woodland, 130 ; suitable for cultivation, 30 . Estimated market value of wood and timber, $\$ 3,000$. House, $30 \times 50$, with L, $25 \times 40,11$ rooms. Barn, $40 \times 60$, with cellar. Fences in good condition. Silo, 30 tons capacity. Will keep 6 cows and 2 horses. Spring water. This farm has an orchard of 50 grafted apple trees, 6 plums, 4 pears. 30 acres is free from rock and stone. Level and machine worked sugar orchard of 300 trees. All the house furnishings of the very best kind, 4 chamber sets, 2 parlor sets, dining set, kitchen utensils and range, everything complete. Railroad station and post office, 2 miles. Price, $\$ 4,000$; $\$ 3,000$ cash; balance at 5 per cent. Address H. A. McCullock, Box 24.

\section{Townshend}

Farm of 205 acres: pasture, 50; woodland, 105; suitable for cultivation, 50. Other acreage 50. Estimated market value of wood and timber, $\$ 1,000$. Barn, $12 \times \dot{z}$, in fair repair. Fences in fair condition. Will keep 10 or 12 cows and 2 horses. Water from spring and brook. Orchard of 50 or more trees, part of them grafts, including. McIntosh and Baldwin apples; also a few cherry trees, grapes, etc. There is an old sugar orchard on the place. The woodland includes a lot of growing spruce, poplar, birch and maple, easy to cut and draw off. The meadow is nearly all level. This is a good apple region, and good views are afforded. Railroad station and post office, Townshend, $3 \frac{1}{2}$ miles. The farm is on an R. F. D. route and there is an opportunity to have a telephone. Price $\$ 900 ; \$ 600$ cash with balance at 5 per cent, $\$ 100$ payable each year. Apply D. S. Brownell, Springfield, Vt.

\section{Townshend}

Farm of 90 acres; pasture 40 ; woodland 30 ; suitable for cultivation 30. Estimated market value of wood and timber $\$ 600$. House $12 \times 24$, not habitable, 4 rooms. Barn $20 \times 30$ in poor condition. Fences in fair condition. Will keep one cow and one horse. Water from well, brook or spring. Orchard of about a dozen apple trees. This place is off the main highway, from Grafton to Townshend. The land is fairly level and timber may be got off easily. This is a timber proposition. All the land is coming up to spruce and pine and if not worked will be covered with forest growth in ten years. Railroad station and post office, Townshend, 4 miles. West Townshend is also available as a railroad station. R. F. D. route and telephone line, $3 / 4$ mile distant. Price $\$ 800 ; \$ 400$ cash, with balance at 5 per cent; payable $\$ 100$ per year. Address D. S. Brownell, Springfield, Vt.

\section{Vernon}

One half acre of land, and house of 22 rooms in good repair. Barn with accomodations for 10 horses, with cellar. Water furnished by a driven well. This place is situated on a state road, and is about $1 / 4$ miles from the Connecticut river power station. 'The dam sets the river back, making a lake 15 miles long which is used by motor boats. Hunting and fishing in season. The house is $2 \frac{1 / 2}{2}$ stories high with large piazzas; is steam heated and newly painted, and contains a large dance hall. There are beautiful shade trees about the house and the buildings are slated. Railroad station and Post Office are only a few rods distant. The house is on a telephone line. Price, $\$ 5,000 ; \$ 1,000$ cash, balance at 5 per cent. Address A. G. Barnes, Vernon.

\section{Wardsboro}

Farm of 90 acres: pasture, 33 ; woodland, 35 ; suitable for cultivation, 20. Estimated market value of wood and timber, $\$ 700$. House, $36 \times 36$, with $\mathrm{L}, 22 \times 20$, in fair repair, 12 rooms. Barn, $40 \times 30$, in fair repair. Fences in good condition. Will keep 8 cows and 2 horses. Runing water 
on the place. Orchard of 145 apple trees, with a few pear and cherry trees. This place is 1 mile from West river on southern slope with a guod view and the soil is rich. There is a large sugar lot, with sugar house and sugar tools for making maple sugar. The buildings include 2 hen houses, a carriage house, corn barn and tool house. Railroad station, Wardsboro, $11 / 4$ miles. Post office, East Jamaica, $1 \frac{1 / 4}{4}$ miles. Price, $\$ 1,700$. Apply F. H. Leonard.

\section{West Wardsboro}

Farm of 14 acres: pasture, 4; other acreage, 2; suitable for cultivation, 8. House, $30 \times 40,8$ rooms in good repair. Barn, $20 \times 30$, with cellar, in good repair. Fences in good condition. This farm has an orchard of 40 apple trees, 8 plum and 4 pear trees. Railroad station, Wardsboro, 8 miles. P. O., West Wardsboro, $2 \frac{1}{2}$ miles. Price, $\$ 400$ cash. Apply to L. G. Stocker.

\section{West Wardsboro}

A farm of 31 acres: woodland, 27; suitable for cultivation, 4. Estimated market value of wood and timber, $\$ 450$. Large $21 / 2$ story house with L contains 13 rooms, in fine repair. Barn, $24 \times 36$, with cellar, in good repair. Silo with 2 tons capacity. Will keep 1 cow. Excellent water. Orchard of 6 grafted trees. House painted white, double piazza, pleasant location. Automobile stage 3 times daily in summer. Near church, store, postoffice, etc. This must be sold and is a bargain. Railroad station, Wardsboro, 9 miles. R. F. D. and telephone. Price, $\$ 1,200$ cash. Address J. C. Tibbetts, Newfane, Vermont.

\section{Westminster Station}

Farm of 10 acres all of which is suitable for cultivation. House, $28 \times 38$, with L. $16 \times 24$; very nice throughout; 8 rooms. Barn, $34 \times 48$, with cellar, in good repair. Fences in good condition. Will keep 4 cows, and 2 horses. Spring water in house and barn. A few apple, pear and plum trees and currant bushes. This place is well located on the main highway, near stores and canning factory and only 1 mile distant from Walpole, N. H., and $3 \frac{1 / 2}{2}$ miles from Bellows Falls. The land is easily tilled, there are no stone, and all of it can be cultivated. The buildings are in excellent condition, painted and slated, and provided with blinds. Maple trees furnish good shade. Railroad station and post office, Westminster, only 25 rods distance. Price, $\$ 2,500$; cash, $\$ 1,250$, with balance at 5 per cent. Address F. H. Atwood.

\section{Westminster Station}

Farm of 4 acres, all suitable for cultivation. House, $22 \times 28$, with $\mathrm{L}$, $12 \times 15$, in extra good repair; house $1 \frac{1}{2}$ stories high with 8 rooms. Barn, $32 \times 32$, almost new and connected to house. Fences in good condition. Will keep 1 cow and 1 horse. Very good water supply. There are a few apple, pear and plum trees, and currant bushes on the place. A confectionery and tobacco store and the post office are located in front part of the house. This is considered a good trade location and the income pays 20 per cent of the asking price. Railroad station 120 feet distant, and Westminster Station postoffice is located in the house. Price, $\$ 3000$ for quick sale; $\$ 1,500$ cash, with balance at 5 per cent. Address F. H. Atwood.

\section{Westminster}

Farm of 90 to 100 acres: pasture, 50; under cultivation, 46 acres, free from stone, and 20 more suitable for cultivation, but now in pasture. There are 100 sugar maples on the farm. Double house, $30 \mathrm{x} 40$, with $\mathrm{L}, 25 \times 30$, in good repair; number of rooms, 14. Each tenement rents for $\$ 10$ per month. Barn, $20 \times 30$ and another $38 \times 75$, with cellar in 
good repair. Pasture fences in good condition. Large silo and hay to sell. Will keep 25 cows and 3 horses. Water from spring and well. Orchard of 15 apple trees and a few plum and pear trees. This farm is in the Connecticut valley tobacco belt, good location and soil for gardening and good market. Corn cannery near which pays $\$ 17$ per ton for sweet corn. There are many good building lots on the farm for which there is a demand. If timber is desired the owner has 2 good timber lots nearby that he would sell with the farm or separately. Railroad station 5 rods distant across the highway. Post office on corner of farm. Price low, $\$ 3,000$ cash and balance at 5 per cent. Address Willis V. Farr, Vernon.

\section{Vilmington}

A summer home with 3 acres of land on Deerfield river bank, partly wooded; tine maple shade trees, good soil. 6 room convenient house, modernized. Railroad station and postoffice, Wilmington, 1 mile over level, good road; also a good barn and carriage house. Good high school and mail delivered. Price and terms right for quick buyer. Address C. B. Tuthill.

\section{Vilmington}

Farm of about 85 acres, with house, $23 \times 44$ and L, $16 \times 22,7$ rooms in good repair. Barn, $25 \times 45$, and one $25 \times 28$, in good repair. Fences in good condition. Will keep 10 cows and 2 horses. Running water. This farm has an orchard of about 175 apple trees divided in Baldwins, Greenings, and Sweets. Hen house, $10 \times 16 ; 1$ fine cow, 2 two year old heifers, 1 heifer calf, $3 \frac{1 / 2}{2}$ months old, 12 Rhode Island Red hens, new sugar house and all equipments, can set 1000 buckets, over 700 buckets now on hand. A wood-lot of spruce, hemlock, birch and beech timber. All small farming tools, 2 mowing machines, wagon, carriage, sleigh etc. 10 cords of wood ready for the market; about 10 tons of fine hay in the barn. This place would make a fine summer home, as it commands a splendid view of the mountains. All the land slopes to the south. Railroad station, Wilmington, $3 \frac{1 / 2}{2}$ miles; post office, Wilmington, 3 miles; R. F. D. and telephones about a mile from house. Price, $\$ 3,000$. Address C. O. Wentworth.

\section{Windlam}

Farm of 10 acres. This piece of lard is situated on main road, and at one time buildings stood on it. It is well adapted for bungalows or a house for summer people, high land, beautiful view. Railroad station, West Townshend, 5 miles; postoffice, Windham, $1 \frac{1 / 4}{4}$ miles. R. F. D. and telephone line. Price, $\$ 200$. Address M. H. Ingalls.

\section{South Windham,}

Farm of about 125 acres: 35 acres tillage, balance wood and pasture land. There is a quantity of young growing timber on the place. This farm has wintered the past season 6 cows, 5 head of young cattle and 3 horses. Barn, $30 \times 40$, with shed attached, wagon shed, ice house, and swill house. Blacksmith shop $12 \times 55$; hen house. A few young fruit trees. Can set 600 buckets in sugar orchard. 7 room house in good repair. Never failing well water. Railroad station 3 miles. Postoffice, church, store and school 1-3 mile. Telephone connection. Will sell with or without stock. Address W. L. Tenney.

\section{WINDSOR COUNTY}

\section{Andover}

Two farms in one with good set of buildings on each. 275 acres; 185 woodland, and suitable for cultivation, 90. Estimated market vai- 
ue of wood and timber, (standing) $\$ 2,500$. House, $24 \times 28$, with L, $20 \mathrm{x}$ $30 ; 7$ rooms. Another house, $28 \times 32$, with L, $20 \times 56 ; 6$ rooms; both in good repair. Barns, $20 \times 30 ; 30 \times 56$; and two $30 \times 40$, in good repair. Fences mostly wire in good condition. Farm will cut 80 to 100 tons. Will keep 23 cows and 2 horses. Spring water. Sale will include 11 heifers, coming 3,8 calves, 1 yoke of oxen, yearling buli. An orchard of all kinds of apples, 8 kinds of pears, 3 kinds of plums. We sell from 40 to 50 barrels of graft apples every year. This is a beautiful location for a summer home or for the taking of city boarders. The location is very healthful and the scenery fine. We want to sell on account of old age and as soon as possible. Railroad station, Chester, or South Londonderry either 9 miles. Post office, Chester, 8 miles. R. F. D. and telephone. Price, \$5,000 cash. Address James O. Sawyer, R. F. D. 2, Chester, Vermont.

\section{Bethel}

A small farm of 65 acres, divided into woodland, tillage and pasture. Very nice lawn. Comfortable $1 \frac{1}{2}$ story house. Located on well-traveled road, R. F. D. and telephone lines pass the house. One mile from the growing town of Bethel, which is on the Central Vermont railway. Address A. W. Perkins.

\section{Bridgewater}

Five hundred acres timber land, about two-thirds of it covered with second growth spruce large enough for timber or pulp, and the rest of it with old and second growth hard wood. All easy of access, roads running through it, an excellent place for a mill. House, $20 \times 30,2$ rooms, nearly new. Spring water. Railroad station, Woodstock, $S$ miles. Post office, Bridgewater, $2 \frac{1}{2}$ miles. Price, $\$ 25$ per acre. Address B. F. Weeden.

\section{Bridgewater}

Farm of 40 acres: pasture, 25; suitable for cultivation, 15. House, $20 \times 30$ with 7 rooms and basement, in good lepair. Barn, $30 \times 40$ with cellar, in good repair. Fences in good condition. Will keep 4 cows and 2 horses. Spring water. Orchard of 50 apple trees, 3 pear trees, 1 plum tree and 1 grape vine. This place is situated on a hill orerlooking the valley of the Ottaquechee river. It would make an ideal summer home or poultry farm; electric lights if desired; running water at house and barn. A woolen mill which employs about 150 hands is situated $1 / 2$ mile from the farm. Railroad station, Woodstock, 6 miles; postoffice, Bridgewater, $1 / 2$ mile. R. F. D. and telephone. Price, $\$ 1,500$; $\$ 900$ cash, balance at 6 per cent. Address E. C. Solger.

\section{Bridgewater}

One half acre of land suitable for cultivation, with house, $20 \times 30$; $\mathrm{L}, 18 \times 25,11$ rooms, in good repair. Barn, $30 \times 40$, with cellar, in good repair. Fences in good condition. Good water. This is village property consisting of house, barn, 2 sheds and store well stocked, and doing from $\$ 20,000$ to $\$ 25,000$ business per year. Woolen mill here emplojs 125 hands. Poor health is the reason for selling. Railroad station, Woodstock, 6 miles; postoffice, Bridgewater, 40 rods: has telephone. Price, $\$ 8,000 ; \$ 4,000$ cash, balance at 5 per cent. Address E. A. Davis.

\section{Cavendish}

Farm of 91 acres: pasture, 40; woodland, 20 ; suitable for cultivation, 31. Estimated market value of wood and timber, $\$ 1,000$. House, 2 story brick, $26 \times 36$ with fine cellar. L, $16 \times 36,9$ rooms besides closets, in fine repair. Two barns, $30 \times 40$ each, one in fine repair. Fences in good condition. Will keep 10 cows, 3 horses. Running spring water. An orchard of 75 apple trees, 1 fine pear, 2 cherries, blackberries and strawberries. 
Land lies nearly level, practically all machine mowed. Fine trout fishing. Maple sugar orchard of 450 trees, on good road. Horse barn, $20 \mathrm{x}$ 34 ; wagon house, $20 \times 38$; hen house, $16 \times 26$; hog house, $14 \times 26$, with arch and kettle, all in very good repair. One-half mile to school, near good neighbors. Railroad station and postoffice, Cavendish, $2 \frac{1 / 4}{4}$ miles. R. F. D. and telephone. Price, $\$ 2,700 ; \$ 1,500$ cash, balance at 5 per cent. Address John D. Dix.

\section{Cavendish}

Farm of 150 acres: pasture and woodland, 110; tillage and mowing, 40. Estimated market value of wood and timber, $\$ 1000$. (Estimated 1,000 cords wood and 100,000 feet timber.) House, $24 \times 34$, with L, $20 \times 40$ (consisting of milk room, woodshed and work shop) 9 rooms, needs some repair. Barn, $40 \times 60$ with cellar, in fair repair. Fences in fair condition. Will keep 8 cows and 2 horses. Spring and well water. An orchard of 75 apple trees, 3 pear trees and several grape vines. House insured for $\$ 400$; barn insured for $\$ 300$. One-fourth mile to school. Farm can easily be made to carry 15 cows and team. Railroad station, $5 \frac{1}{2}$ miles; postoffice, Felchville, 2 miles; R. F. D. Price, $\$ 1,500$; $\$ 500$ cash; balance at 5 per cent. Address G. W. VanCor, Felchville, Vt.

\section{Chester}

Farm of 165 acres: pasture, 50 ; other acreage, 65 ; suitable for cultivation, 50. Estimated market value of wood and timber, $\$ 700$. House, $26 \times 36$ with L, $20 \times 36 ; 6$ rooms down stairs and 5 up stairs, in good repair. A cow barn, $30 \times 40$; and horse barn, $20 \times 40$; in good repair. Fences in good condition. Will keep 12 to 15 cows. A good supply of water. An orchard of 40 to 50 apple trees, consisting of Baldwins, Greenings, and common fruit. A piazza 60 feet long on one siae of the house. Also store and wagon house, $20 \times 60$ nearly new. Railroad station, and postoffice, Chester, 3 miles; R. F. D. and telephone. Price, $\$ 1,900 ; \$ 900$ cash; balance at 6 per cent. Address H. A. Barton.

\section{Chester}

Farm of about 100 acres: woodland, 60 ; suitable for cultivation, 40 . Enough wood and timber for home use. New house, $24 \times 26$ with L, $12 \times 14 ; 7$ rooms, in good repair. New barn, $32 \times 36$, with cellar, in good repair. Fences in good condition. Will keep 8 to 10 cows. Good water supply, An apple orchard of a good many young Baldwins, Spies, Greenings - 50 trees or so. There is a nice bay window, also a 26 fnoi piazza on one side of the house. Railroad station and post office, Chester, $31 / 2$ miles; R. F. D. and telephone. Situated on stage road. Price, $\$ 1,400 ; \$ 700$ cash, balance at 6 per cent. Address H. A. Barton.

\section{Chester}

Farm of 34 acres woodland, 20 ; other acreage, 2 ; suitable for cultivation, 12. Modern 2 story house, $41 \times 23$, with L, $44 \times 18 ; 10$ rooms with pantry, workshop, laundry and storeroom, in fair condition. The house has two bay windows and two piazzas. Barn, $30 \times 271 / 2$, not in repair. Fences in medium condition. Will keep 1 cow and 1 horse. City water, well and spring on hill. An apple orchard of $2 \mathrm{Hub}$. Nonesuch, 2 Sweets, Talman and fall, 2 Astrachans, 1 Porter, 2 Pippins, 2 late fall fruit and 1 pear tree. This farm is situated on high ground in the village corporation, in reach of electric lights. Fruit trees are scattering, have named only half, all are good fruit. Under cultivation farm would keep 2 cows and horse. A good wood lot, from 30 to 40 years growth. House has parlor, sitting room, dining room, bedroom, large pantry, kitchen in ell, 5 chambers on ground floor, 3 chimneys, fireplace, cellar well aired. Railroad station $1 \frac{3}{4}$ miles and postoffice, Chester, 1 
mile; R. F. D. and on telephone line. Price, $\$ 3,500$. Address, G. L. H., Box 284 , Chester, Vermont.

\section{Chester Depot}

A farm of 40 acres: this piece of pasture land contains an excellent site for a summer hotel, fille outlook, good drainage, easy access, good roads and drives in every direction. About equally distant from Springfield, Proctorsville, Cavendish and Chester. Adjacent to land on which are situated the Chester chalybeate springs, known for their medicinal qualities, for more than a century. Railroad station, Gassetts, 2 miles; postoffice, Chester Depot, 6 miles; R. F. D. For price and further information address Mrs. M. A. Chandler, R. F. D. 2, Chester Depot, Vermont.

\section{Chester Depot}

Farm of 46 acres: pasture, 10; woodland, 20; suitable for cultivation, 16. Estimated market value of wood and timber, on stump, $\$ 400$. House, $36 \times 20$, with L, $24 \times 18$; 5 rooms in good repair. Barn, $30 \times 24$, with cellar, in good repair. Fences in good condition. Will iseep 4 cows and 2 horses. Running water. Apple orchard of 100 trees, consists of 3 Baldwins, 2 Russets, 1 Bell Flower, 2 Orange Sweets, 2 sweet trees, names unknown, 1 Pearmain, 1 Vermont Beauty, 1 Porter, 2 crab apples, the rest are native fruits, winter varieties, a good share of them sweet, a few small plum trees and 2 grape vines. Railroad station, Gassetts, 3 miles; post office Gassetts, 3 miles; R. F. D. Price $\$ 700 ; \$ 300$ cash, balance at 5 per cent. Address A. D. Bradish, R. F. D. 3, Chester Depot.

\section{Chester Depot}

Farm 234 acres: pasture, 100; woodland, 134. Estimated market value of wood and timber, $\$ 10,000$. These timber lots are timbered with spruce, hemlock, red oak, pine, balsam, and a small per cent of hard wood, it is estimated to cut 1,000,000 feet of lumber. These lots are situated on a good road and can be cut off summer or winter with a portable mill-the timber is large enough to cut off any time. Come and see them and be convinced. Railroad station and postoffice, Chester Depot, $2 \frac{1}{2}$ miles. Price $\$ 10,000$. Address Chas. F. Howe.

\section{Quechee}

Farm of 20 acres all of which is suitable for cultivation. House, $30 \times 40$, in good repair, 9 rooms. This is an old-fashioned colonial house with 5 fire places and brick oven in good condition. There is a rery good cellar under the whole house. Barn, $30 \times 48$, with cellar in good repair. Fences in good condition. Will keep 3 cows and 2 horses. Supplied with spring water. Orchard includes Spies, Baldwins, Fanieuse, August Sweets, Astrachans, pear and cherry trees and other fruit. There are 25 butternut trees on the place. This place would make a fine summer residence. The scenery is very attractive and the celebrated Quechee Gulf is only $1 / 2$ mile distant. Railroad station and postoffice, Quechee $1 / 2$ mile. Price, $\$ 1,250$; half in cash and balance at 5 per cent. Apply Elmer W. Weeden.

\section{Hartiord}

Farm of 180 acres: pasture and woodland, 110; suitable for cultivation, 70 . House, $32 \times 42$, with L, $24 \times 38$, in good repair; 16 rooms. 3 barns with cellar, in good repair. Fences in fair condition. 2 silos, with a capacity of 100 tons. Will keep 20 cows and 5 horses. Water supply from never failing springs. Orchard of 600 apple trees, 60 pear trees, also plums and cherry. Railroad station and postoffice, Quechee, $1 \frac{1}{2}$ miles; telephone line passes through here. Price right for cash. Address H. A. Henderson. 


\section{West Hartford}

Farm of 40 acres, on the main road, 10 miles from White River Junction, and 3 miles from West Hartford. The house contains 20 rooms and is beautifully furnished. It was built 24 years ago. The large barn containing all conveniences, is furnished in hard pine and was built 23 years ago. The property cost $\$ 25,000$ and is offered for sale for $\$ 5,000$. Address A. P. Reynolds, Box 113.

\section{Hartland}

Farm of 75 acres: pasture, 35 ; woodland, 10 ; suitable for cultivation, 30. Estimated market value of wood and timber, $\$ 1,000$. House, $24 \times 32$, with L, $18 \times 30$, nearly new, 14 rooms. Cow barn, $28 \times 70$; with shed attached, and cellar under the whole. New horse barn, $24 \times 30$. Fiences in good condition. Silo, $12 \times 22$ with capacity of 35 tons. Will keep 20 cows and 2 horses. Nevel failing supply of water at house and barn. Orchard of 400 trees, 200 in bearing, including Northern Spies and other varieties; also grapes and pears in abundance. The farm is in first class condition. There is a sugar orchard of 1000 trees and 1200 buckets may be hung. Railroad station, Hartland or Woodstock, 5 miles; postoffice, Woodstock, 5 miles; school 1/2 mile. R. F. D. and telephone. Price, $\$ 3,600$. $\$ 1,800$ cash, with the balance at 5 per cent. Apply George D. Bagley, R. F. D. 2, Woodstock.

\section{Hartland}

Farm of 16 acres: pasture, 3; woorland, 6; suitable for cultivation, 7. Estimated market value of wood and timber, $\$ 200$. House, $23 \times 30$, with $\mathrm{L}, 20 \times 30$, a one story house painted and in good repair; 7 rooms. Barn, 24 x 36, with cellar, in good repair. Fences in good condition. Will keep 2 cows and 1 horse. Water at barn. Orchard of about one dozen trees, Snows and Spies. The farm is on a good traveled road from Hartland to Woodstock, nearly all the land is level, and the farm is in a good state of cultivation. Railroad station, Hartland, $3 \frac{1}{2}$ miles; postoffice, Hartland Four Corners, $1 \frac{1}{2}$ miles, where church and stores are located; school, $1 / 4$ mile; R. F. D. and telephone. Price, $\$ 1,800 ; \$ 900$ cash with balance at 5 per cent. Address George D. Bagley, R. F. D. 2, Woodstock.

\section{Ludlow (South Hill)}

Farm of 140 acres: pasture, 85; woodland, 15 ; suitable for cultivation, 40. Estimated market value of wood and timber, $\$ 600$. House, $25 \times 32$, with $\mathrm{L}, 18 \times 30$, in good repair; 9 rooms. There are 2 large pantries and 6 sleeping rooms. Barn, 40 x 70, with cellar, in good repair; other buildings include wagon shed, workshop, corn house, and sugar house. Over 300 buckets can be put out. The buildings are very convenient. Fences in good condition. Silo with 100 tons capacity. Will keep 25 cows and 2 horses. A never failing spring supplies water to house and barn. Orchard of more than 100 trees; 30 Northern spies, the rest Red Astrachan, McIntosh Reds, Baldwins, Greenings, Pound Sweets, etc. This is considered one of the best farms in town. Railroad station and postoffice, Ludlow, 3 miles; R. F. D. and telephone. Price, $\$ 2,800$ cash. Address Charles H. Morgan, Ludlow.

\section{Norwich}

Farm of 200 acres: pasture, 75 ; woodland, 50; suitable for cultivation, 75. Estimated market value of wood and timber, $\$ 1,000$. House, $28 \times 38$, with L, $18 \times 32$, in fair repair; 6 rooms. Barn, $30 \times 40$, with cellar, in fair repair. Horse barn, $20 \times 40$, with cellar. Corn barn, $18 \times$ 20 ; hen house, $12 \times 48$; Shop or tool house $15 \times 15$. Fences in good condition. Will keep 20 cows and 4 horses. Supply or spring water. 
Orchard of 75 apple trees of standard varieties and a few pear trees. Place 4 miles from Dartmouth College. Railroad station, Norwich, $3 \frac{1}{2}$ miles; postoffice, Norwich, 3 miles; R. F. D. and telephone. Price, $\$ 1,800 ; \$ 1,100$ cash, with balance at 6 per cent. Address John H. Eastman, White River Junction.

\section{Norwich}

Farm of 100 acres: pasture, 50; suitable for cultivation, 50. Estimated market value of wood and timber, $\$ 1000$. House, $181 / 2 \times 40$, with $\mathrm{L}, 25 \times 27$, in fair repair; 9 rooms. Barn, $40 \times 36$, with cellar, in fair repair. Fences in good condition. Will keep 15 cows, 20 young cattle and 2 horses. Running water. A few fruit trees. The soil is a clay loam, with 10 or 15 acres loam meadow, and cuts 50 or 60 tons of hay. The farm was badly run down, but is producing more each year and its output easily can be doubled. The locaition is excellent and is only 1 mile from Dartmouth College. Railroad station, Norwich and Hanover, N. H., 1/2 mile; post office, Norwich, 1/2 mile; R. F. D. route and 2 telephone lines go by the house. Price, $\$ 600 u$. Address E. G. Lord.

\section{Plymouth ('Tyson)}

Farm of 54 acres: one pasture, 9; woodland and pisiure, 34; suitable for cultivation, 15. Estimated market value of wood and timber, $\$ 500$. House, $32 \times 26$, with L, $20 \times 16 ; 9$ rooms, in fair repair. Barn, $30 \times 26$, with cellar, in good repair; hen house, $14 \times 36$. Fences mostly barb wire, in good condition. Will keep 3 cows and 1 horse. Water in house and barn. Orchard of 65 trees, including, Baldwins, Pippins and Porters. Part of the trees are common fruit. There are 2 summer hotels within half a mile; Echo Lake is only $3 / 4$ mile distant; store and church 1/2 mile distant. There is a good market for eggs, butter and poultry at the summer hotels, and Ludlow furnishes a good market for produce. Railroad station, Ludlow, $5 \frac{1}{2}$ miles; postoffice, Tyson, $1 / 2$ mile. Price, $\$ 800$ cash. Address E. C. Manley, Tyson, Vt.

\section{Pomfret}

Farm of 150 acres; pasture, 60 ; woodland, 60 ; suitable for cultivation 30. Estimated market value of wood and timber, $\$ 1000$. The hard wood is estimated at 2000 cords mostly maple, some basswood and butternut. House, $40 \times 36$, with L, $40 \times 20$, in fair repair; 7 rooms. Barn, $80 \times 30$, with cellar, in good repair. Horse barn, $30 \times 20$. Wire fences. Silo, with capacity of 75 tons. Will keep 25 cows and 2 horses. Running water at house and barn. Orchard of 400 trees, many varieties mostly winter fruit. Railroad station, Woodstock, 6 miles; postofiice, Pomfret, also store, town hall and school house, $1 / 2$ mile; R. F. D. and telephone. Price $\$ 4000 ; \$ 3000$ cash, with balance at 5 per cent. Tinis price includes stock and tools. Address Geo. W. Potter, Box 62.

\section{Pomfret}

Farm of 240 acres: pasture, 160 ; woodland, 30 ; meadow, 50 . Estimated market value of wood and timber, $\$ 2,000$. House, $30 \times 2 \bar{\tau} ; \mathrm{L}, 24 \mathrm{x}$ $24 ; 16$ rooms, in good repair. Furnace, hot and cold water and bath room. Barn, $100 \times 30$, with cellar, in good repair. Corn house, wagon house and sugar house. All buildings clapboarted and painted. Fences in good condition, mostly wire. Farm will keep 30 cows, 3 horses. Never failing water. Orchard of 100 trees, consisting of Greenings, Baldwins, Kings, etc. Sugar orchard, capacity, 1500 buckets. Nearly level mowing; hay all cut by machine. Railroad stations, Woodstock and IVest Hartford. P. O., Pomfret, 1 mile. R. F. D. and telephone. Price, including farming tools and all sugar apparatus, $\$ 7,500 ; \$ 3,000$ cash, balance at jo per cent. Address George W. Harding. 


\section{Reading (Hammondsville)}

Farm of 5 acres: woodland, 1; suitable for cultivation, 4. Estimated market value of wood and timber, $\$ 50$. House, $35 \times 45$, with $\mathrm{L}, 25 \mathrm{x}$ 28 , in good repair; 18 rooms; in the upper story is a hall, $30 \times 45$. House lighted by electricity. Barn, $24 \times 30$, with cellar, in good repair. Fences in good condition. Will keep 1 cow and 1 horse. Running water. A few fruit trees. Location is a pleasant one, on state road from springfield to Woodstock. Railroad station, Windsor, 12 miles; post office, Felchville, 3 miles. Price, $\$ 1,500 ; \$ 1000$ cash, balance at 5 per cent. Address Abram Finch, R. F. D., Felchville.

\section{Rochester}

Farm of 160 acres: pasture, 50; woodland, 85; other acreage, 25; suitable for cultivation, 25. Estimated market value of wood and timber, $\$ 2,500$. House, $34 \times 26$; L, $40 \times 15$ 1-3; 12 rooms in good repair. Barn, $67 \times 44$, with cellar, in good repair; horse barn, carriage room, etc. Fences in fair condition. Silo. No. tons capacity, 142. Will keep 15 cows, 2 horses. Spring water. Apple orchard of about 90 trees. Fine sugar place of 800 trees; sugar house. Railroad station and P. O., Rochester, $3 / 4$ mile. R. F. D. and telephone. This is considered one of the pleasantest locations in the White River valley, and would make an ideal summer home. Place is located on the main road following the river. Rochester is a thriving place and growing rapidly. Price, $\$ 4,500 ; \$ 3,500$ cash, balance at 6 per cent.

\section{Royalton}

"Jones Place" of 160 acres: pasture, 60; woodland, 60 ; other acreage, 40 ; suitable for cultivation, 40. Estimated market value of wood and timber, $\$ 2,500$. House, $25 \times 40 ; \mathrm{L}, 20 \times 30$, with shed; 8 rooms, in fair repair. Barn, $30 \times 50$; cellar, in fair repair. Fences in fair condition. Silo; No. tons capacity, 20. Will keep 12 cows, 2 horses. Good water. Apple orchard of 50 or more trees; sugar orchard. Place not occupied now. Always owned by one family. R. R. station, South Royalton, 2 miles. P. O., Royalton, $13 / 4$ miles. R. F. D. Price, $\$ 2,000 ; \$ 800$ cash, balance at 5 per cent. Address William Skinner.

\section{Royalton}

The "Rix Place" of 200 acres: pasture, 80 ; woodland, 60 ; other acreage, 60 ; suitable for cultivation, 60 . Estimated market value of wood and timber, $\$ 4,000$. Brick house, $30 \times 40$; wooden L, $20 \times 40 ; 7$ rooms in house and 3 in $\mathrm{L}$; in fair repair. Barn, $30 \times 60$; cellar, in good repair. Fences in fair condition. Silo. No. tons capacity, 7 . Will keep 40 cows, 3 horses. Good water. R. R. station and P. O., Royalton, 1 mile. R. F. D. and telephone. This farm has stood owned and occupied for 100 years in the name of "Rix." The most desirable location, and carries with it everything for making farming profitable. All farm work can be done by machinery. Price, $\$ 10,000 ; \$ 5,000$ cash, balance at 5 per cent. Address Katherine Rix Skinner.

\section{Royalton}

Farm of 200 acres: pasture, 75; woodland, 75; other acreage, 50. 250,000 feet of timber, $1 / 2$ mile to mill. 3,000. cords of wood valued at $\$ 6$ per cord, market $1 \frac{1 / 2}{2}$ miles. House, $35 \times 25 ; \mathrm{L}, 35 \times 20 ; 12$ rooms, in good repair. Barn, $129 \times 44$; cellar, in good repair. Silo. No. tons capacity, 60 . Will keep 30 cows, 3 horses. Water at house and barn. Fences in good condition. Orchard of 100 apple, 4 pear, 8 plum, 3 cherry trees; currants and grapes. Sugar orchard of 400 trees, all equipped. Very picturesque view from house. Farm adjoins the White river. Good neighbors. R. R. station, Royalton, $1 \frac{1 / 2}{2}$ miles. P. O., $3 \frac{1 / 2}{2}$ miles. R. 
F. D. and telephone. Price, $\$ 5,000 ; \$ 4,000$ cash; balance at 5 per cent. Address M. A. and E. A. Daniels.

\section{South Royalton}

Farm of 175 acres: pasture, 65 ; woodland, 40 ; suitable for cultivation, 70. Estimated market value of wood and timber, $\$ 3,500$. House, 38.9 x $26.6 ; \mathrm{L}, 24 \times 16 ; \mathrm{L}, 38.6 \times 18 ; 12$ rooms; in good repair. Two barns, $30 \times 40$, in fair repair; hen house, $52 \times 13$. Fences in fair condition. Silo. No. tons capacity, 75. Will keep 25 cows, 4 horses. Pasture watered by brook. Running water at house and barn. Two good trout brooks. 100 apple, 7 pear, 5 plum and 3 cherry trees. 50 blackberry plants, 300 strawberry plants set last summer. Very early sugar bush of 700 trees, equipped. Plenty of good shade around house. Church, store, and creamery at East Barnard, $11 \frac{1}{2}$ miles. R. R. station and P. O., South Royalton, 7 miles. R. F. D. and telephone. Price $\$ 3200 ; \$ 2400$ cash, balance at 6 per cent. Will sell with or without stock and tools. Address D. E. Sneden.

\section{South Royalton}

Farm of 3 acres, all suitable for cultivation. House, $31 \times 25$; L, $20 \times 17 ; 8$ rooms in good repair. Barn, $35 \times 30$; cellar, in good repair. Fences in good condition. Will keep 2 cows, 1 horse. Spring water. About 50 graft apple trees in second year of growth. About 25 currant, 50 raspberry and 50 blackberry bushes. A good village farm for market gardening. R. R. station and P. O., South Royalton, 70 rods. Telephone. Price, $\$ 2500 ; \$ 800$ cash, balance at 5 per cent. Address Earle E. Wilson.

\section{South Royaiton}

Farm of 150 acres: pasture, 100 ; other acreage, 10 ; suitable for cultivation, 40. Estimated market value of wood and timber, $\$ 1000$. House $35 \times 28 ; \mathrm{L}, 20 \times 16 ; 7$ rooms, in good repair. Barn, $104 \times 44$; cellar, in good repair. Fences in good condition. Silo. No. tous capacity 50. Will lieep 20 cows, 3 horses. Good water. Orchard of 35 trees. R. R. station and P. O., South Royalton, 1 mile. R. F. D. and telephone. Is in graded school district. This farm is one of the best farms in town. A good stock or milk farm. On good road. Price $\$ 3000 ; \$ 1000$ cash, balance at 5 per cent. Address E. C. Martin.

\section{Sonth Royalton}

Farm of 100 acres: pasture, 45; woodland, 30 ; suitable for cultivation, 25. Estimated market value of wood and timber, $\$ 1000$. House, $30 \times 35 ; \mathrm{L}, 16 \times 20 ; 9$ rooms, in good repair. Barn, $30 \times 40$; in good repair; with lean-to for stable. Fences in good condition. Silo. No. tons capacity, 30 . Will keep 10 cows, 2 horses. Good water. Orchard of about 20 trees. R. R. station and postoffice, South Royalton, $2 \frac{1}{4}$ miles. R. W. D. and telephone. A very pleasant place, on a good road, in the graded school district. Price, $\$ 1800 ; \$ 900$ cash, balance at 5 per cent. Address E. C. Martin.

\section{South Royalton}

Farm of 8 acres, all tillage land. House, $30 \times 24 ; \mathrm{L}, 24 \times 14 ; 10$ rooms. House shingled last summer, 1912; hard wood floors in dining room and kitchen; a good bath room with good supply of water; sewer to river; new furnace; good cellar under main part of house. Barn, $36 \mathrm{x}$ 30 ; cellar; in good repair. All buildings newly painted. Silo, built two years ago, 20 feet deep, 10 feet in diameter. Place will keep 4 cows, 1 horse. R. R. station and postoffice, South Royalton, less than $1 / 4 \mathrm{mile}$. Telephone. Price $\$ 3500$; one-half cash; balance at 5 per cent. Address C. W. Cowen, South Royalton. 


\section{Sharon}

Farm of 135 acres: pasture, 50; woodland, 50; other acreage, 35; suitable for cultivation, 35 . Estimated market value of wood and timber, $\$ 1000$. House, $28 \times 32 ; 9$ rooms, in fair repair. Barn for 8 cows and 4 horses, with bay; in fair repair. Will keep 8 cows, 2 horses. Fences in good condition. Spring water. Orchard of 67 trees; 50 common fruit, 3 Baxter, 1 Wolf River, 6 Bellflower, 2 Pewaukee, 1 Talman Sweet, 2 plum and 1 pear. Good sugar orchard. R. R. station, Sharon, $2 \frac{1}{2}$ miles. P. O., Sharon, $23 / 4$ miles. Price, $\$ 1600 ; \$ 1000$ cash, balance at 5 per cent. Address H. P. Batchelder.

\section{Springfield}

A four acre property: two acres suitable for cultivation. Land slopes to the south. House, $28 \times 32 ; 8$ rooms; built 3 years ago. Barn, 24 x 30 ; built 3 years ago. A modern house, with paih, hot and cold water, fire-place, screens, storm doors and windows. Floors are of hard wood, linoleum and soft wood. Porcelain set tubs, toilet on first floor, set bowls in two chambers. Electric lights in all buildings. Place will keep 1 cow, 1 horse. Fences in good condition. Spring water. Orchard of about a dozen bearing trees, 75 small apple and cherry trees. Ice house. Hen houses and pens for 200 birds. Incubator house with 1200 egg Candee hot water incubator. Brooder house for 1400 small chicks, hot water heat; poultry, stock and tools if wanted. House up from road, nice view no dust. Black river runs noxt to highway. Boating on the Connecticut river, 1 mile on the electrics. Also some black bass fishing. One-fourth acre each of strawberries and asparagus, a few berries, currants, etc. A fine place for party wishing to carry on small poultry business, or for a summer home. Good place for summer boarders. $R$. $R$. station, Charlestown, N. H., 3 miles. Property is situate on line of springfield Electric Railway between Charlestown and springfield. P. O., springfield, 3 miles. R. F. D. and telephone. For further particulars, address D. S. Brownell.

\section{North Springfield}

Farm of 17 acres: all suitable for cultivation. $21 \frac{1}{2}$ story house, $33 \mathrm{x}$ $25 ; \mathrm{L}, 39 \times 21 ; 8$ rooms, in good repair. House is painted, has piazza on two sides. Piazza on $\mathrm{I}$, from kitchen door. Good, large front yard. Barn, $30 \times 40$, with cellar, in good repair. Horse bal'n, $30 \mathrm{x} 27$. Workshop and wood shed, $20 \times 29$. Cow stable is in basement, stanchions for 8 cows; good box stall. Fences in good repair. Farm will keep 6 to 8 cows, 2 horses. Good water. Orchard of Greenings, Baldwins, Fameuse or Snow. On stage line to Gassetts. R. R. station, Gassetts, 3 miles. P. O., North Springfield, $1 / 8$ mile. Price, $\$ 2,500 ; \$ 1,500$ cash; balance at 5 per cent. Address Mrs. Emma L. Keith, 23 Whitcomb St., Springfield, Vt.

\section{Stockbridge}

The "Len Newell Farm" of 30 acres: pasture, 8 acres; woodland, 12 ; suitable for cultivation, 10 . Plenty of wood. House, $20 \times 26 ; \mathrm{L}, 24 \times 36$; $\mathrm{L}, 18 \times 24 ; 14$ rooms, in good repair. Barn, $24 \times 30$, cellar, in good repair. Place cuts 8 or 10 tons of hay. Will keep 3 or 4 cows, 1 horse. Fences in good condition. Running water at house and barn. Orchard of about 40 trees, consisting of Duchess, Northern Spy, Pound Sweet, Baldwin, Tetoskies, Williams' Favorite and other varieties. Excellent soil. Some gold in the sand along the river. Would make good place to keep boarders in the summer. R. R. station and P. O., Gaysville, $1 \frac{1 / 2}{2}$ miles. R. F. D. and telephone. Price, including a quantity of wood and some other personal property. $\$ 1,400 ; \$ 1,000$ cash; balance at 6 per cent. 


\section{Stockbridge (Gaysville)}

Farm of 95 acres; pasture, 20; woodland 50; suitable for cultivation 25. Estimated market value of wood and timber $\$ 2,500$; estimated 200 feet hard and soft wood. House $31 \times 30 ; \mathrm{L}, 60 \times 21 ; 10$ rooms in good repair; barns $41 \times 30$; $34 \times 22$; horse barn $44 \times 30$; cellar, in good repair, fences in good condition. Will keep 10 cows and 2 horses, running water in house and barns, about 50 apple trees nearly all grafts. R. R. station, Gaysville, 3 miles. Flag station, Riverside $3 / 4$ mile. P. O., Gaysville, 3 miles. R. F. D. and telephone. Price $\$ 2,200 ; \$ 1,800$ cash; balance on interest 5 per cent. This price includes some stock and farming tools, also household furniture. Address, John Schneider, Jr., Gaysville, Vt.

\section{Weathersfield (Perkinsville)}

Farm of 160 acres: pasture, 60; woodland, 25; other acreage, 75; suitable for cultivation, 75. Plenty of wood and timber for use and repairs. $1 \frac{1}{2}$ story house, $36 \times 30 ; \mathrm{L}, 1$ story; 8 rooms, good repair. Two large barns in fair repair. Three hen houses and an ice shed. No. tons capacity, 60 or 70 . Will keep 16 cows, 3 horses. Fences in good condition. Great supply of water. Grafted and common fruit. Farm is on road between Windsor and Springfield. Springfield electric station, 6 miles. Milk and cream taken at farm. School team comes to farm every school day. Graded school. Farm is very level and easy to care for. Good soil with quick returns. Beautiful scenery; very desirable for a summer home. R. R. station, Gassetts, 6 miles. P. O., Perkinsville, 1 mile. R. F. D. and telephone. Price, $\$ 2,800 ; \$ 1,200$ cash; balance at 6 per cent. Address Esther G. Diggins.

\section{Woodstock}

Farm of 200 acres: pasture, 100 ; woodland, 50; suitable for cultivation, 50. Estimated market value of wood and timber, $\$ 2,000$. Machine worked fields. House, $32 \times 48,10$ rooms, good repair. Barns, 28 $\mathrm{x} 36,26 \times 46,40 \times 50,30 \times 40,26 \times 38$, two cellal's, fair repair. Silo, No. tons capacity, 100. Will keep 25 cows, 4 horses. Fences in good condition. Water at house and barn. Orchard of 440 apple, 10 pear and 8 plum trees. Farm is situated on the Ottaquechee river, between Woodstock, a thriving village, and Bridgewater, a manufacturing town. At Woodstock is an up-to-date inn which is filled with guests the year around, making a good market for farm produce. Stock and tools to purchaser if desired. R. R. station, Woodstock, 4 miles. P. O., West Woodstock, 3 miles. R. F. D. and telephone. Price, $\$ 6,000 ; \$ 3,000$ cash; balance at 5 per cent. Address Allen L. Minor.

\section{Woodstock}

Village property, with $1 / 4$ acre of land. House built about $\&$ years ago; is in exceilent condition. Hardwood floors down stairs. Steam heat, electric lights, fine pantry and a large, handsome buffet sideboard built in the dining room. Cement cellar bottom. A nice vegetable cellar separate from main cellar. Bath room, with hot and cold water, upstairs. Toilet and running hot and cold water down stairs. House is situated on a corner commanding a pleasant view in all directions; gets the sunshine all day. Barn, $21 \times 30$, in good repair. Room for three horses. This property is within ten minutes' walk of all places of interest in the village. P. O., 1/8 mile. Telephone. Price, $\$ 5,000$. Address Everett P. Ashley.

\section{Woodstonk}

The C. E. Darling homestead, situated five miles from the beautiful village of Woodstock, Vermont; 3 miles from Hartland 4 Corners; $4 \frac{1}{2}$ miles from the Central Vermont Railroad station, Hartland, Vermont. Cream gathered at door, free mail delivery, telephone connec- 
tions. $1 / 2$ mile from school, good neighborhood with near neighbors. Plenty of work to be obtained at good wages. Six churches at Woodstock, High school, Y. M. C. A., fine market for all produce and best advantages.

Cottage house of eight rooms, large halls, pantry, woodshed and carriage room. Barn, $42 \times 50$; also shed and corn barn; running spring water at house and barn and a good well.

The farm consists of 45 acres, 18 of which is in tillage, 27 in pasture and woodland. Fine orchard with the best varieties of fruit; beautiful old-fashioned garden. Productive soil adapted for special or general farming. Unsurpassed scenery; good roads for teaming or automobiling, one of the most attractive places in a rarely beautiful section. Price, $\$ 2000$. For further particulars, address A. B. Morgan, Woodstock, Vermont. 


\section{INDEX}

A rricultural Advisers

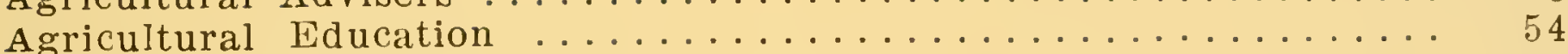

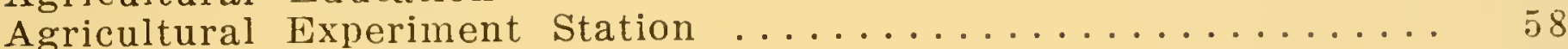

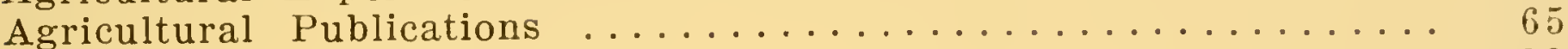

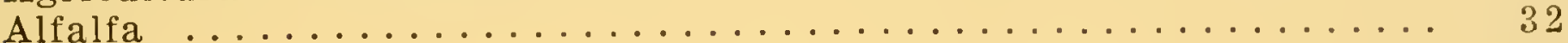

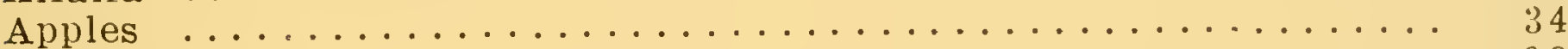

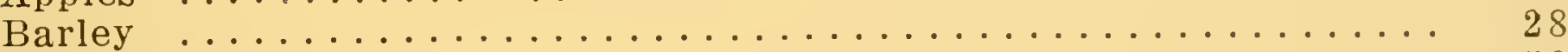

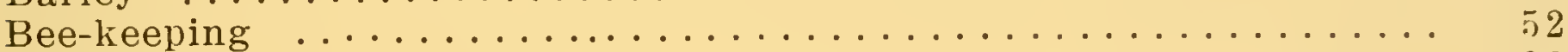

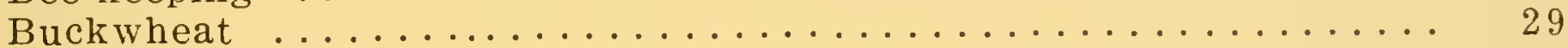

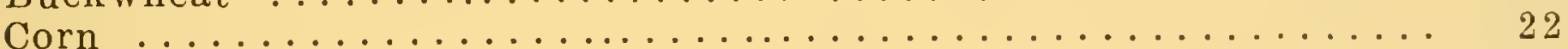

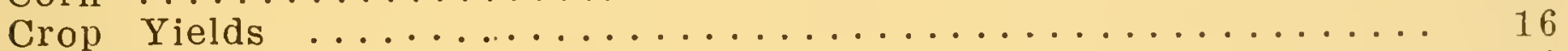

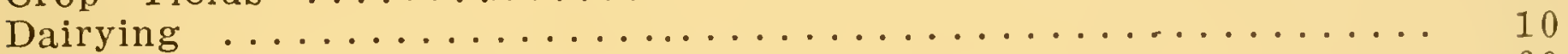

Farming, some Vermont examples of $\ldots \ldots \ldots \ldots \ldots \ldots \ldots$

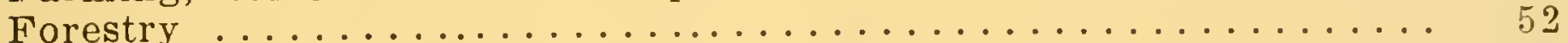

Horses

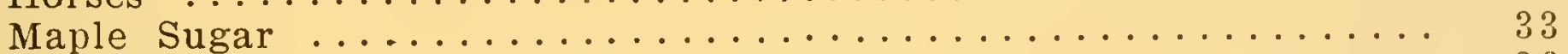

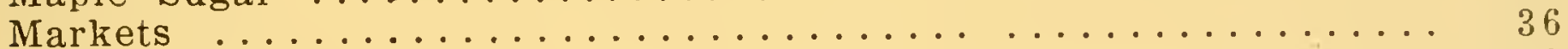

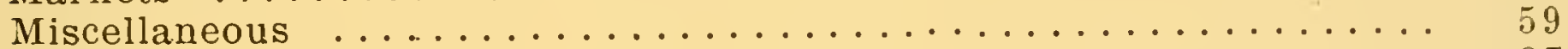

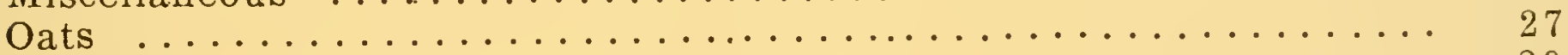

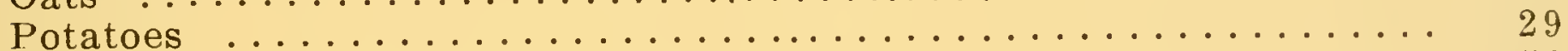

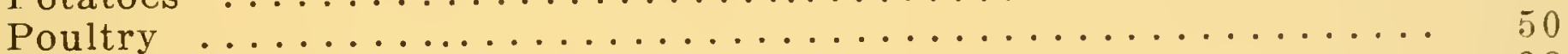

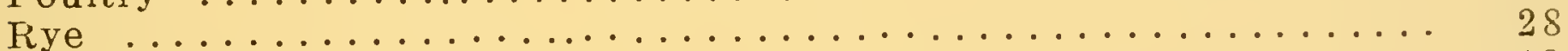

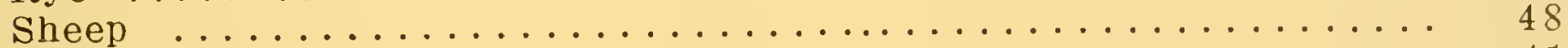

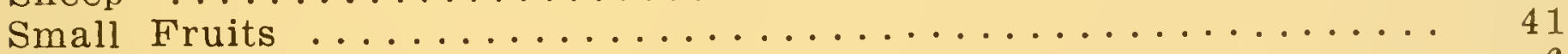

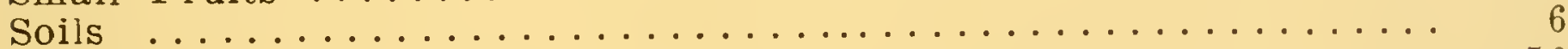

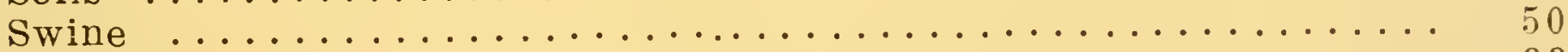

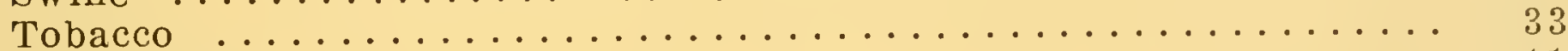

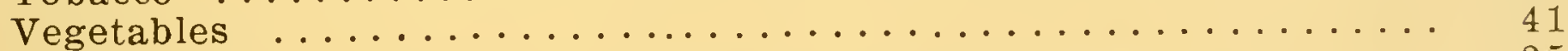

25

INDEX TO FARM ADVERTISEMENTS $\ldots \ldots \ldots 103$

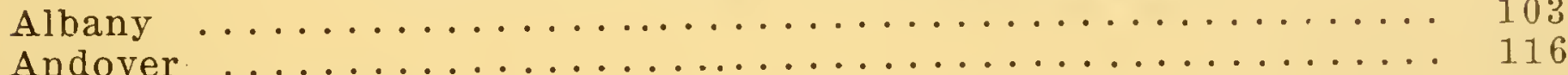

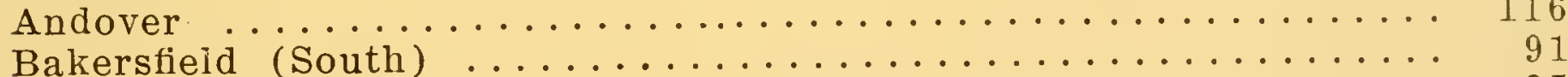

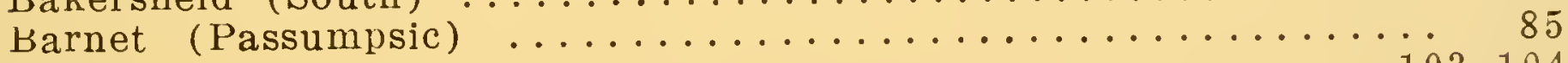

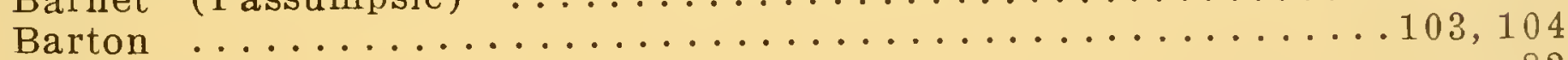

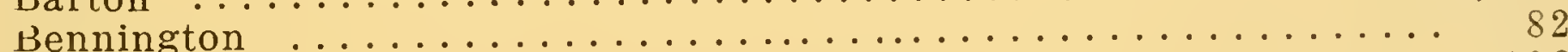

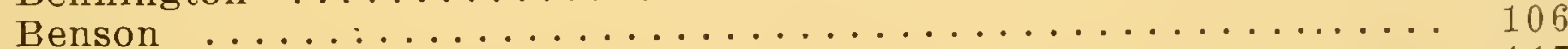

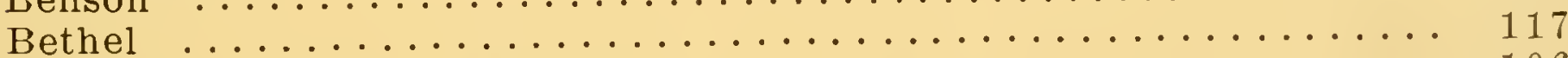

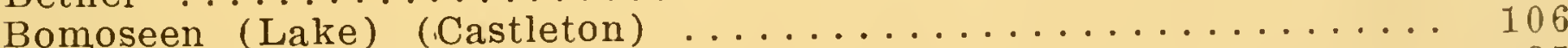

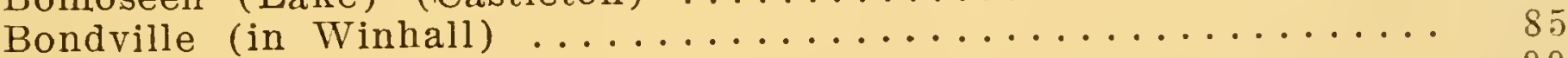

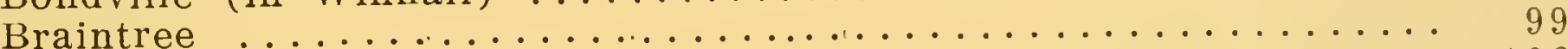

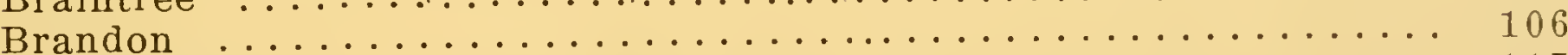

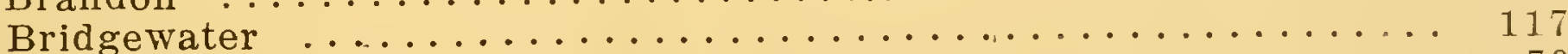

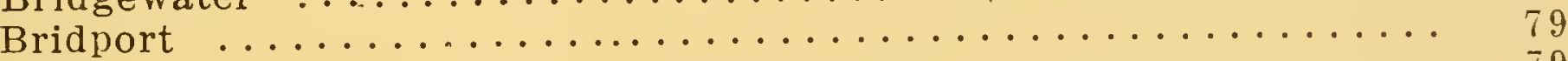

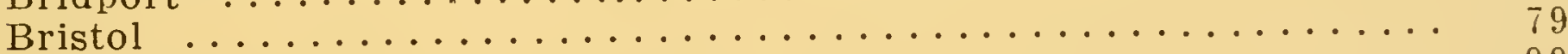

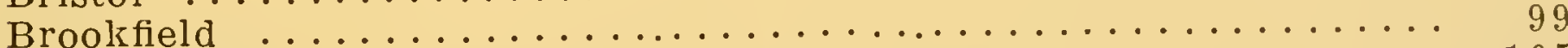

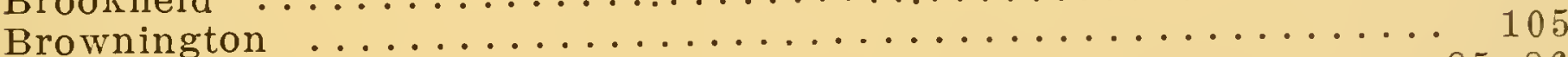

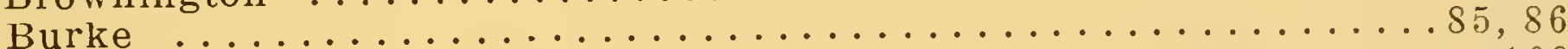

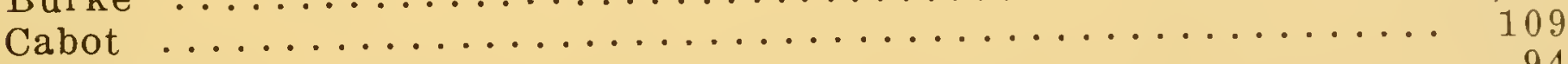

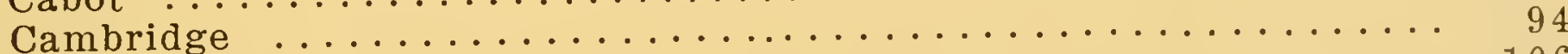

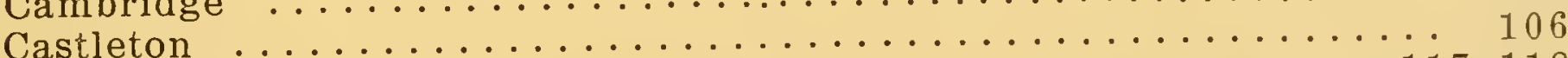

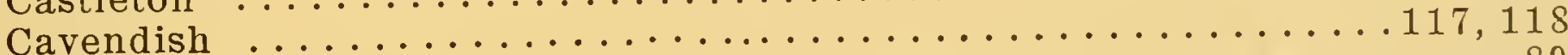

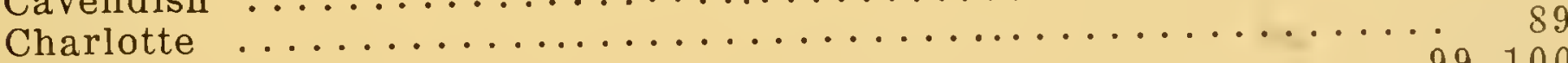

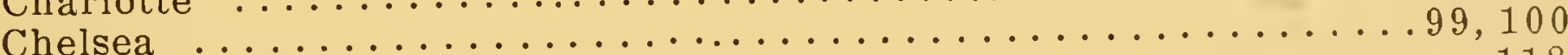

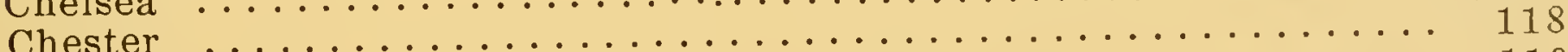

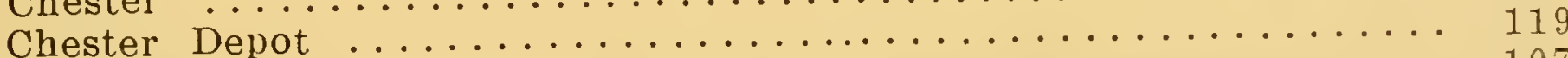

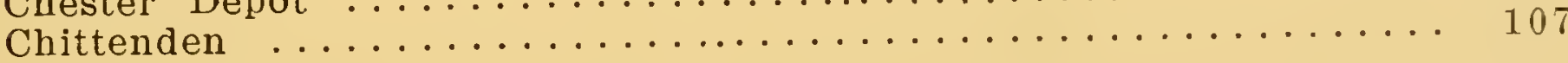




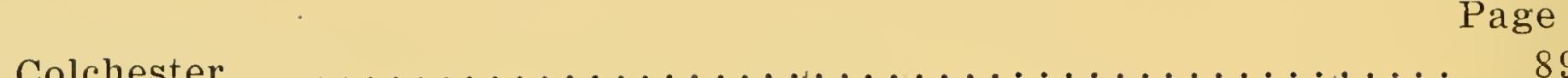

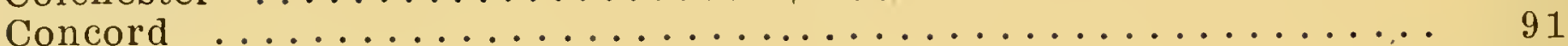

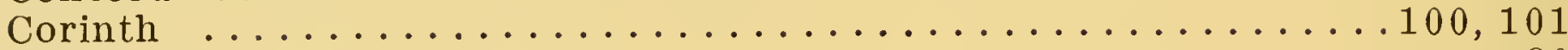

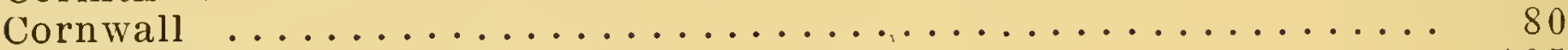

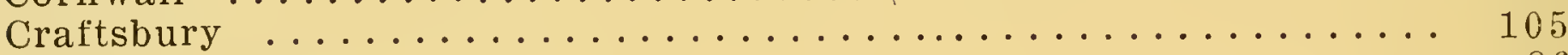

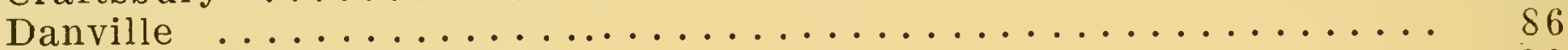

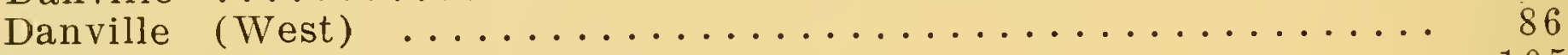

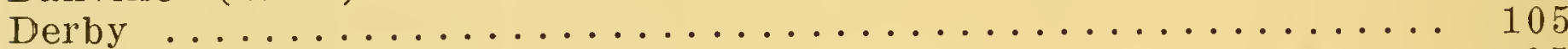

Dorchester Heights (Morristown) ................. 95

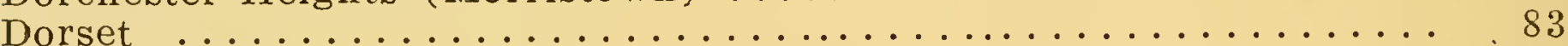

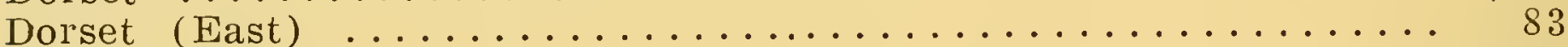

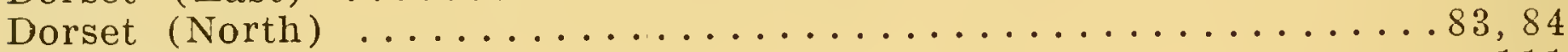

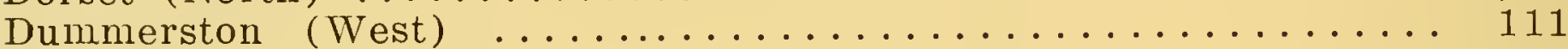

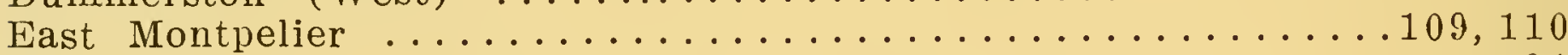

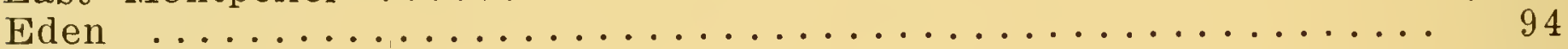

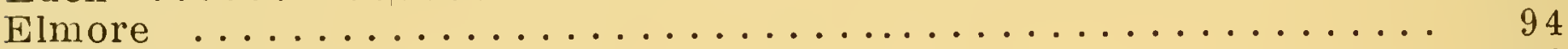

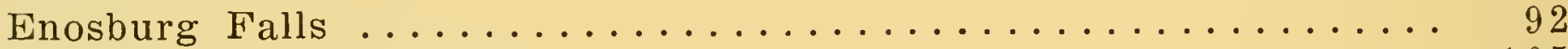

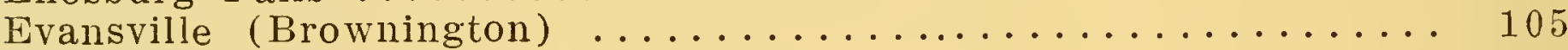

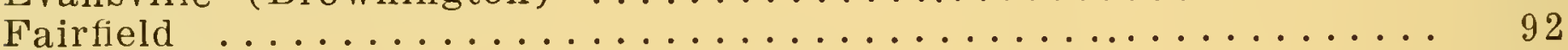

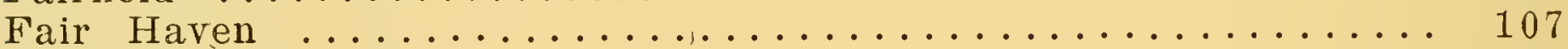

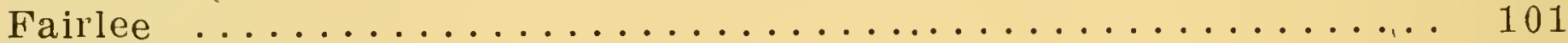

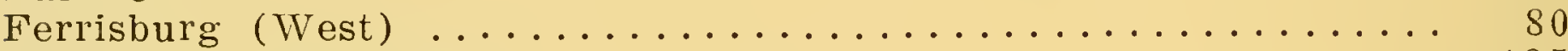

Gaysville (Stockbridge) ..................... 125

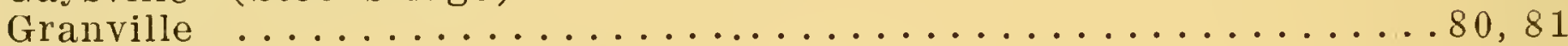

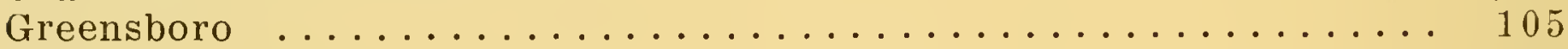

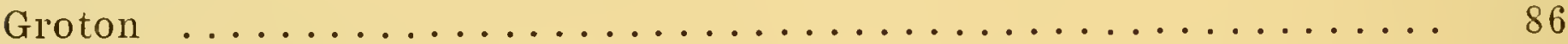

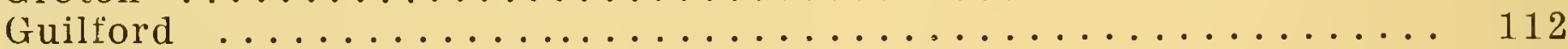

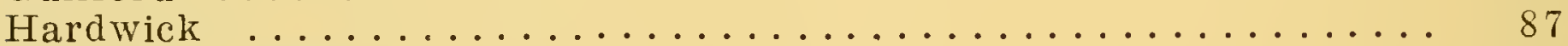

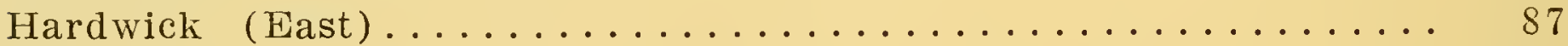

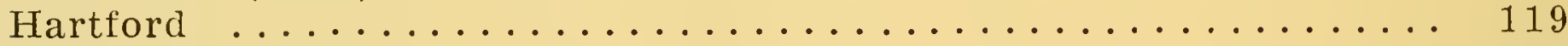

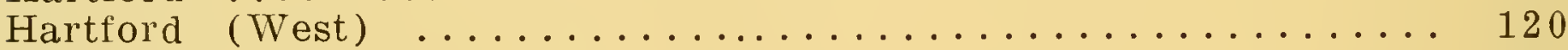

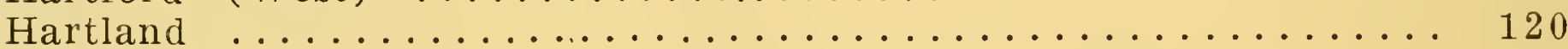

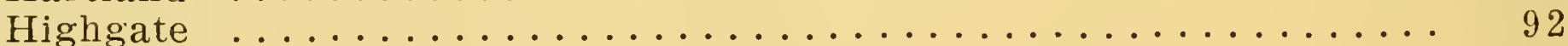

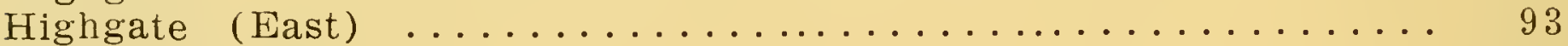

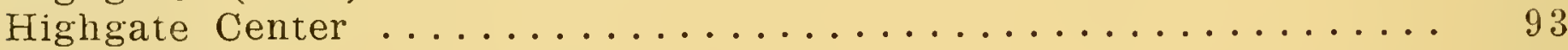

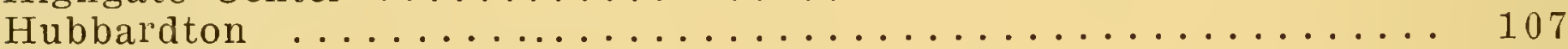

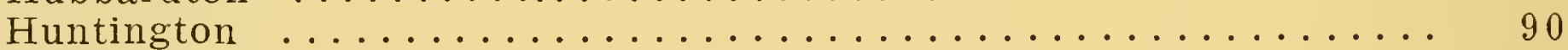

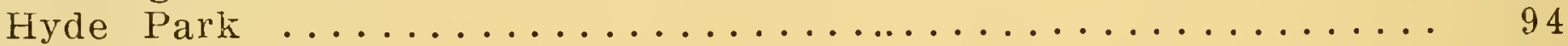

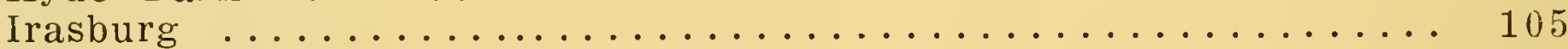

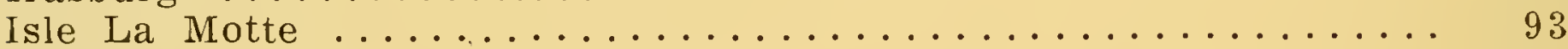

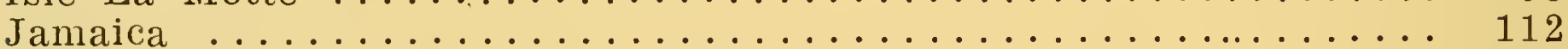

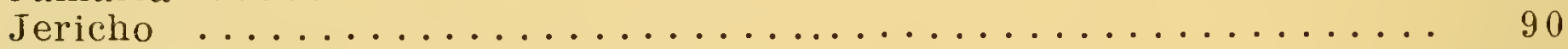

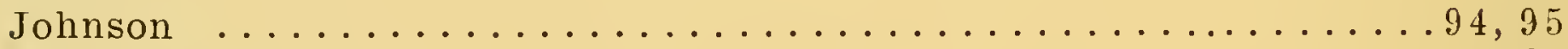

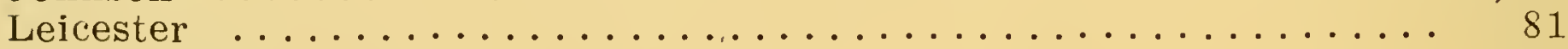

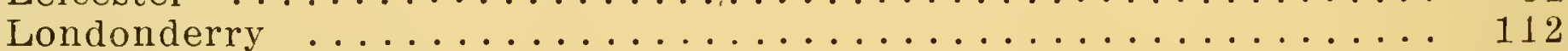

Ludlow (South Hill) ........................ 120

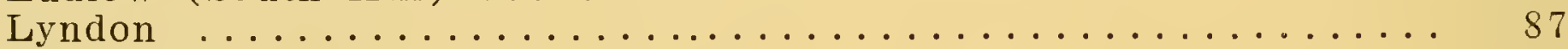

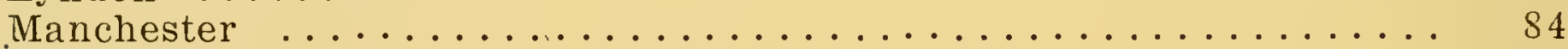

Manchester Center ......................... 84

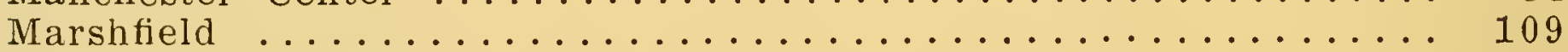

Middlebury (East) ...................... 81

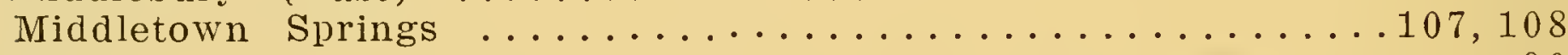

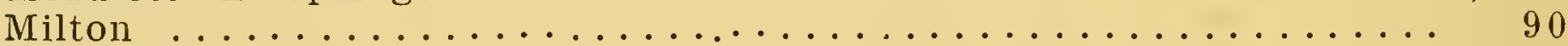

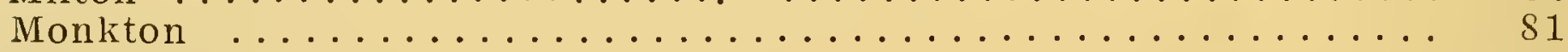

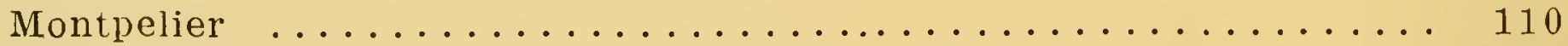

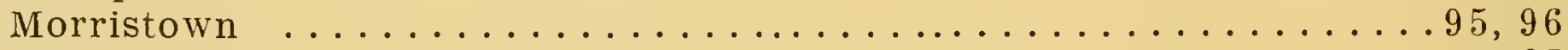

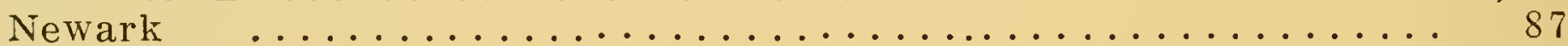

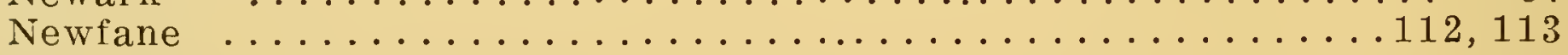

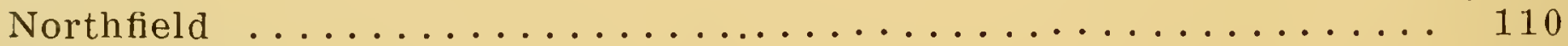

North Hero .............................. 94 
Norwich

Page

Orwell

Passumpsic (in Barnet)

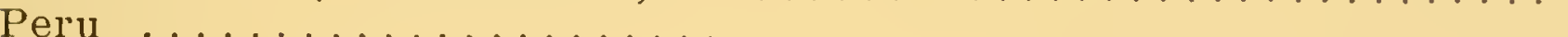

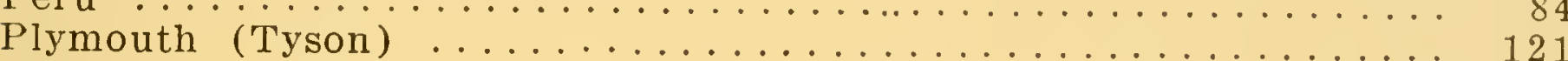

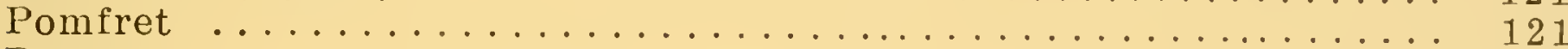

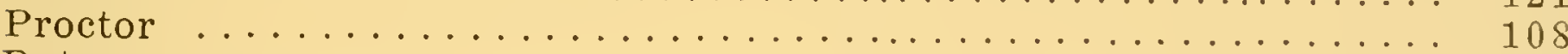

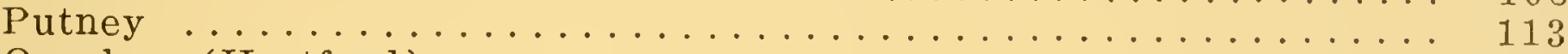

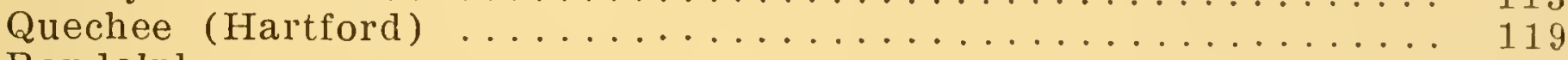

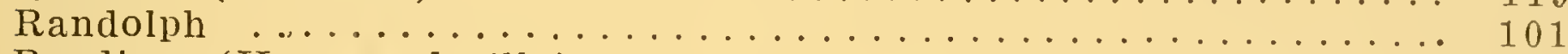

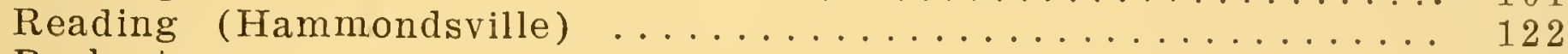

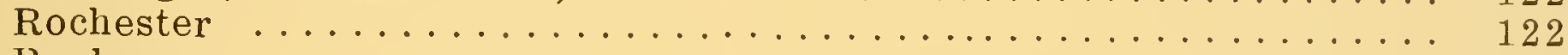

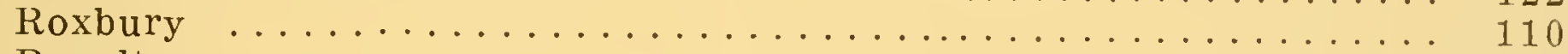

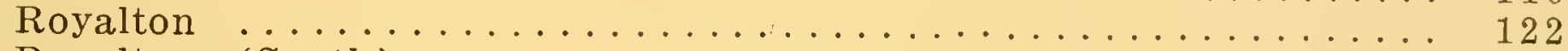

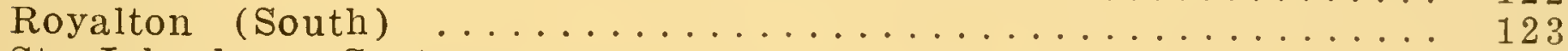

St. Johnsbury Center ...................... s $s$

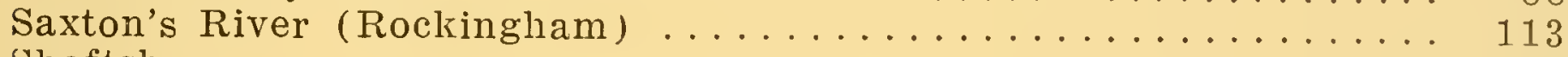

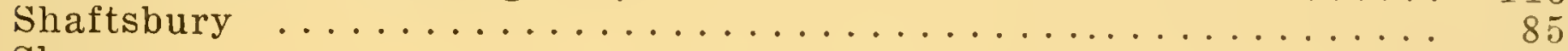

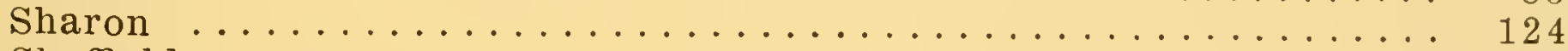

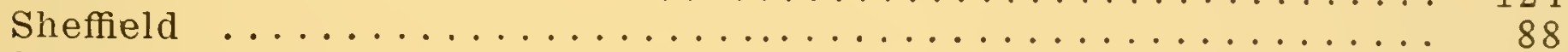

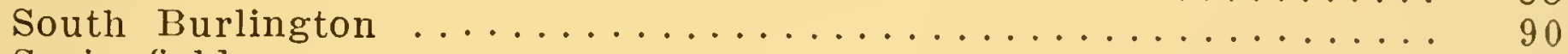

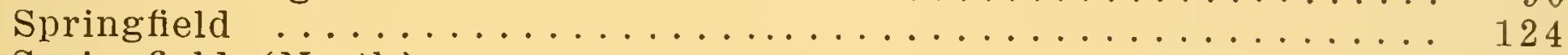

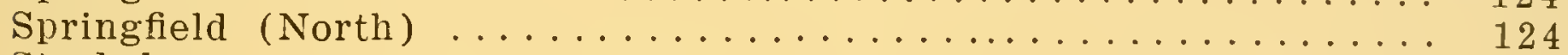

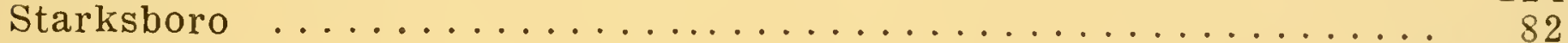

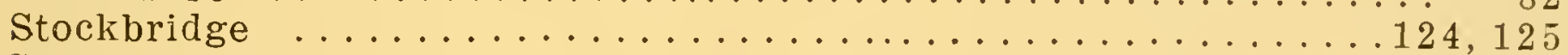

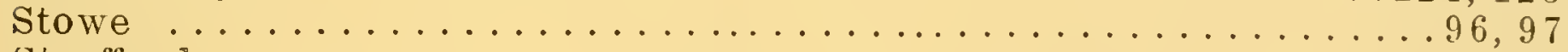

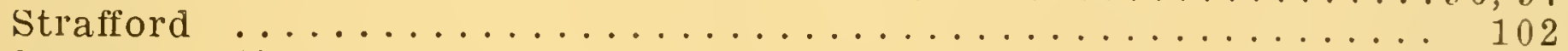

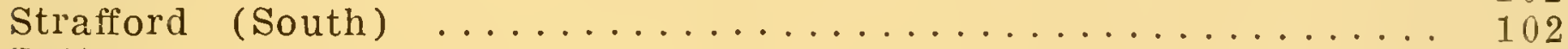

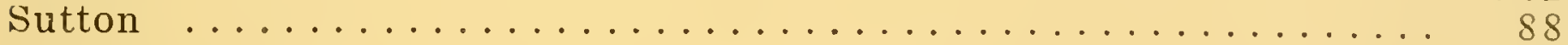

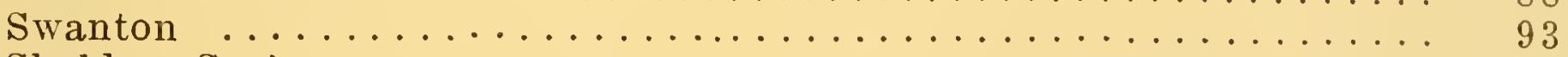

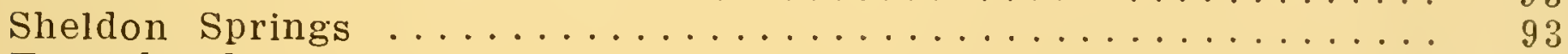

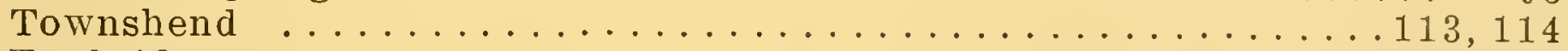

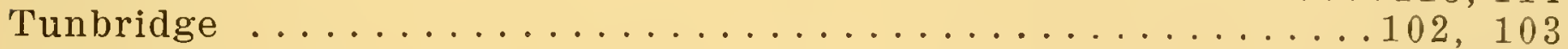

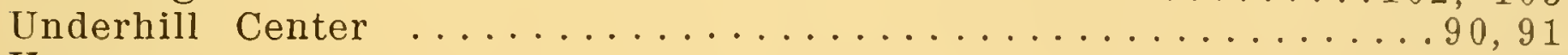

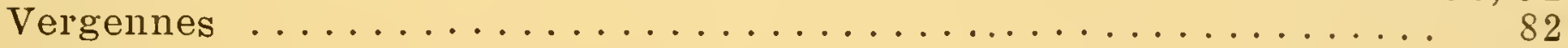

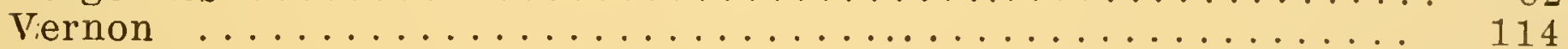

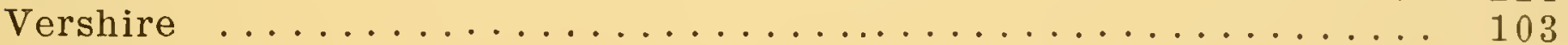

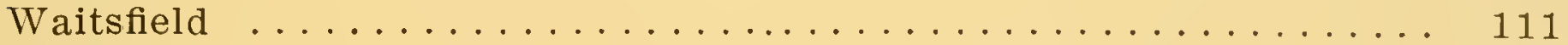

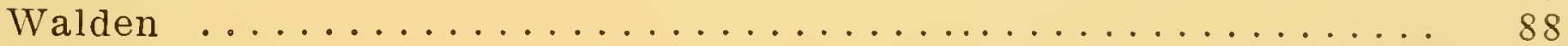

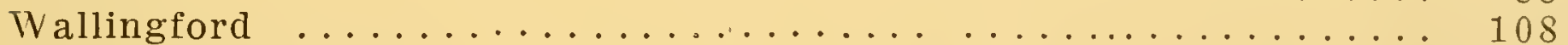

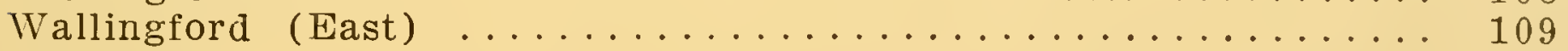

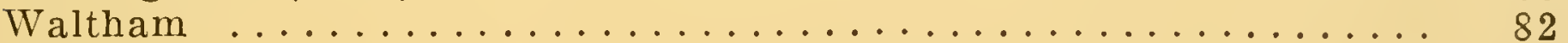

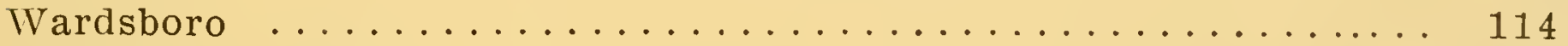

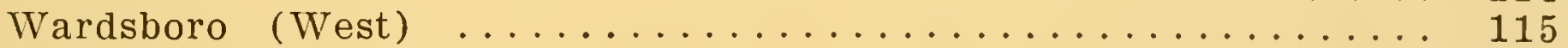

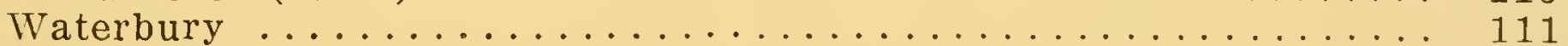

Weathersfield (Perkinsville) ................... 125

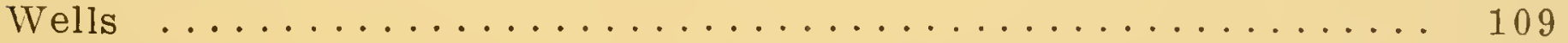

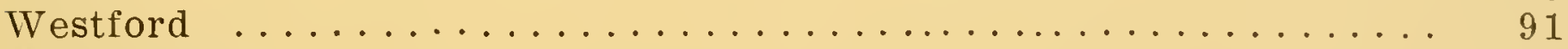

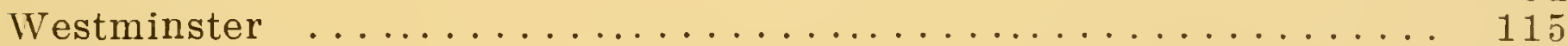

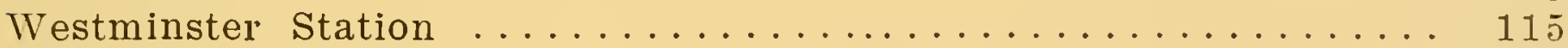

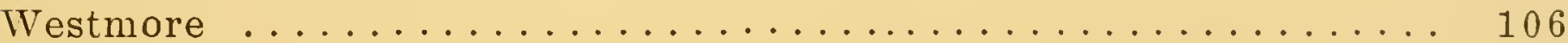

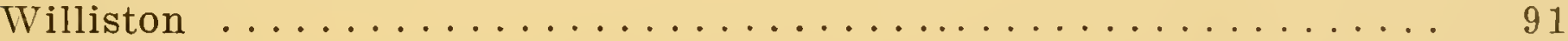

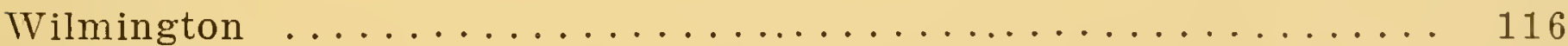

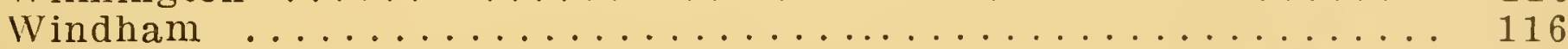

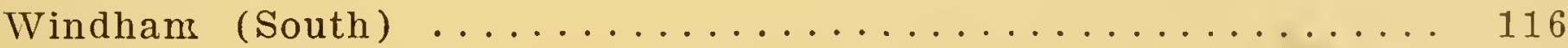

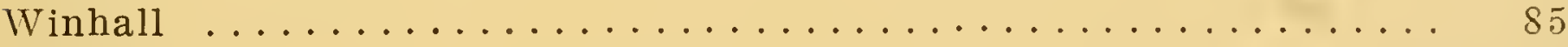

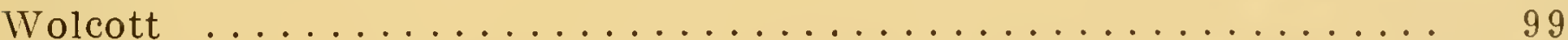

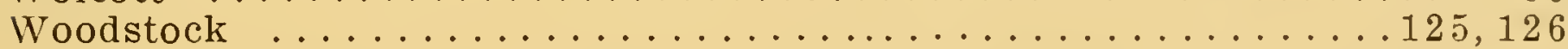










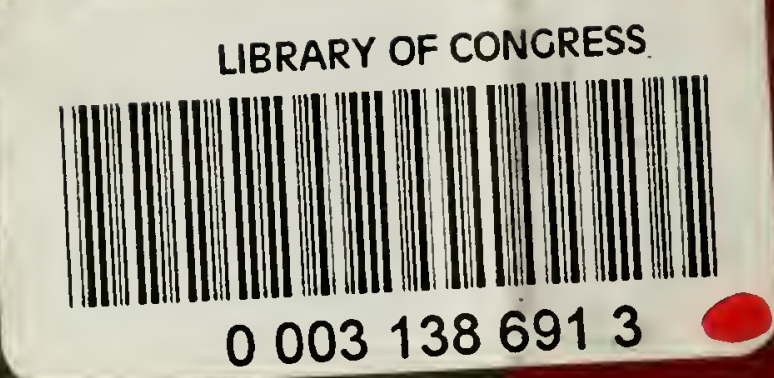

